JACQUELINE SPOLADOR LOPES

\title{
RETALIAÇÃO CRUZADA EM PROPRIEDADE INTELECTUAL NA ORGANIZAÇÃO MUNDIAL DO COMÉRCIO
}

\author{
Dissertação de mestrado \\ Orientadora: Professora Associada Dra. Maristela Basso
}

UNIVERSIDADE DE SÃO PAULO

FACULDADE DE DIREITO

São Paulo

2013 
JACQUELINE SPOLADOR LOPES

\title{
RETALIAÇÃO CRUZADA EM PROPRIEDADE INTELECTUAL NA ORGANIZAÇÃO MUNDIAL DO COMÉRCIO
}

\author{
Dissertação apresentada à Faculdade de Direito da \\ Universidade de São Paulo - USP, como requisito parcial \\ para a obtenção do título de Mestre em Direito \\ Área de Concentração: Direito Internacional e Comparado \\ Orientadora: Prof. ${ }^{a}$ Associada Dr. ${ }^{a}$ Maristela Basso
}


Banca Examinadora: 
A Gustavo, Eleni, Gisele, Vanessa e Valdeci 


\section{AGRADECIMENTOS}

À minha orientadora, Professora Maristela Basso, pela oportunidade, confiança, aprendizado e exemplo acadêmico que nos inspira.

Ao Gustavo pelo amor, companheirismo e compartilhamento de ideias que muito contribuíram para este trabalho.

Aos meus pais pelo amor, confiança e dedicação.

Às minhas irmãs, Gisele e Vanessa, pelo apoio incondicional.

A Sueli, Milton, Luciana e Valdir por me darem suporte nos primeiros passos dessa conquista.

Aos professores Umberto Celli, Vera Thorstensen e Alberto Amaral pelos ensinamentos e incentivo.

Aos representantes do Ministério das Relações Exteriores pelas valiosas contribuições e discussões.

Aos amigos e internacionalistas, pelos debates, revisões e apoio, em especial: Diego Bonomo, Welber Barral, Abrão Neto, José Luiz Pimenta, Aluísio Lima-Campos, Maria Aparecida Santos, Bárbara Brisa, Daniela Oliveira, Karla Borges, Frederico Meira, Beatriz Stevens, Sabina Vieira, Fabricio Polido, Priscilla César e Paulo Lilla. 


\section{LISTA DE ABREVIATURAS}

ABIPECS

ASMC

BIRPI

BRAZTAC

CAMEX

CCI

CLEA

ESC

FMI

FSRI

GATT

GATS

GIPI

IBA

ICJ

ICTSID

IDCID

IFPI

IIPA

INPI

IP

IPC

ITC

MAPA

MDA

MDIC

MF

MP

MRE

NCC
Associação Brasileira da Indústria Produtora e Exportadora de Carne Suína

Acordo sobre Subsídios e Medidas Compensatórias

Bureaux Internationaux Reunis pour la Protection de la Propiete Intellectuelle

Brazil Trade Action Coalition

Câmara de Comércio Exterior

Câmara de Comércio Internacional

Collection of Laws for Electronic Access

Entendimento de Solução de Controvérsias

Fundo Monetário Internacional

Farm Security and Rural Investment

General Agreement on Tariffs and Trade

General Agreement on Trade in Services

Grupo Interministerial de Propriedade Intelectual

Instituto Brasileiro do Algodão

Corte Internacional de Justiça

International Centre for Trade and Sustainable Development

Instituto de Direito do Comércio Internacional e Desenvolvimento

International Federation of the Phonographic Industry

International Intellectual Property Alliance

Instituto Nacional de Propriedade Industrial

Intellectual Property

Intellectual Property Committee

International Trade Commission

Ministério da Agricultura, Pecuária e do Abastecimento

Ministério do Desenvolvimento Agrário

Ministério do Desenvolvimento Indústria e Comércio Exterior

Ministério da Fazenda

Ministério do Planejamento, Orçamento e Gestão

Ministério das Relações Exteriores

National Cotton Council of America 
OCDE

OIC

OMC

OMPI

ONU

OSC

PIB

PMDR

PNB

RIC

SCGP

SGP

SNPC

TRIMS

TRIPS

USTR

USDA

WTO
Organização para Cooperação e Desenvolvimento Econômico

Organização Internacional de Comércio

Organização Mundial do Comércio

Organização Mundial de Propriedade Intelectual

Organização das Nações Unidas

Órgão de Solução de Controvérsias

Produto Interno Bruto

Países de Menor Desenvolvimento Relativo

Produto Nacional Bruto

Remedies Implementation Committee

Supplier Credit Guarantee Program

Sistema Geral de Preferências

Serviço Nacional de Proteção de Cultivares

Agreement on Trade Related Investment Measures

Agreement on Trade Related Aspects of Intellectual Property Rights

United States Trade Representative

United States Department of Agriculture

World Trade Organization 


\section{RESUMO}

A intensificação do comércio e o aumento da interdependência econômica entre os países geram a necessidade de criar regras para assegurar a previsibilidade aos operadores do comércio internacional. A Organização Mundial do Comércio (OMC) criou um sistema de solução de controvérsias, com o intuito de garantir o cumprimento dessas regras. Esse sistema é essencial para permitir que países em desenvolvimento questionem práticas ilegais realizadas por países desenvolvidos, permitindo inclusive a suspensão de concessões ou outras obrigações (retaliação), mediante o cumprimento de certas condições. Todavia, a assimetria econômica entre os Estados muitas vezes dificulta a retaliação no âmbito do mesmo acordo que foi violado por determinado membro da OMC. A suspensão de concessões ou outras obrigações em acordo da OMC diferente daquele violado é conhecida como retaliação cruzada. Nesse contexto, a retaliação cruzada em propriedade intelectual (TRIPS) pode despontar como uma opção para os países em desenvolvimento, quando estes participarem de uma disputa contra países desenvolvidos na OMC. Isso se deve à importância da propriedade intelectual para a economia dos países desenvolvidos. A retaliação cruzada em propriedade intelectual foi autorizada em apenas três casos dos mais de 460 existentes na OMC: EC - Bananas III (DS27), US - Gambling (DS265) e US Cotton (DS267). A última dessas disputas, o contencioso do algodão, envolve um pleito do Brasil em face dos Estados Unidos. Embora tenha sido autorizado nesses três precedentes, o mecanismo jamais foi aplicado. Diante desse cenário, a presente dissertação analisa de forma multidisciplinar, considerando os precedentes mencionados, se a autorização para aplicar a retaliação cruzada em propriedade intelectual induz o cumprimento de decisões adotadas pelo Órgão de Solução de Controvérsias da OMC. Essa verificação considera os desafios de aplicar a retaliação cruzada em propriedade intelectual e os efeitos da ameaça do uso do mecanismo sobre as negociações. No tocante às negociações, é fundamental considerar a interação que ocorre entre os setores público e privado dos dois países envolvidos em determinada controvérsia. Essa influência mútua entre os setores deve ser compreendida à luz da teoria dos jogos de dois níveis, também analisada neste estudo.

Palavras-chave: Organização Mundial do Comércio (OMC); sistema de solução de controvérsias; retaliação cruzada; propriedade intelectual; teoria dos jogos de dois níveis; negociações internacionais; contencioso do algodão. 


\begin{abstract}
The intensification of commerce and the growth of economic interdependence among States provoked the need for rules that promote foreseeability to the players of international commerce. The World Trade Organization (WTO) created a dispute settlement system that aims to enforce such rules. This system is essential to allow developing countries to contest illegal practices applied by developed countries and grant developing countries the possibility to suspend concessions or other obligations (retaliation) whenever certain criteria are met. However, the economic asymmetry among States typically imposes obstacles to the retaliation within the same agreement that has been violated by a WTO member. The suspension of concessions or other obligations of a WTO agreement distinct from the agreement that has been violated is known as cross retaliation. In this context, cross retaliation in intellectual property (TRIPS) may emerge as an option for developing countries when involved in a dispute against a developed country in the WTO. The reason for this is the importance of intellectual property to the economy of developed countries. Cross retaliation in intellectual property has been authorized only in three out of the 460 existing cases in the WTO: EC - Bananas III (DS27), US Gambling (DS265) e US - Cotton (DS267). The last of those disputes, the cotton case, involves Brazil against the United States. Even though the measure has been authorized in all three cases, it has never been applied. This dissertation analyses from a multidisciplinary perspective, considering the referred precedents, whether the authorization to apply the cross retaliation in intellectual property prompts the enforcement of the decisions adopted by the Dispute Settlement Board of the WTO. The analysis considers the challenges intertwined with applying the cross retaliation in intellectual property and the effects that a threat to apply such mechanism causes over the negotiations. Regarding the negotiations, it is essential to consider the interaction between the public and private sectors of the two countries involved in particular disputes. Such mutual influence between the sectors must be understood in light of the two-level games theory, which is also examined in this study.
\end{abstract}

Key-words: World Trade Organization (WTO); dispute settlement system; crossretaliation; intellectual property; two-level games theory; international negotiations; cotton case. 


\section{RÉSUMÉ}

L'intensification du commerce et l'interdépendence accrue entre les pays exigent l'établissement des règles pour assurer la prévisibilité aux opérateurs de commerce international. L'Organisation Mondiale du Commerce (OMC) a crée un système de règlements de différends, afin d'assurer le respect de ces règles. Ce système est essentiel pour permettre aux pays en développement de contester les mesures illicites adoptées par les pays développés, y compris en permettant la suspension de concessions ou d'autres obligations (contre-mesures), sous certaines conditions. Cependant, l'asymétrie économique entre les États entrave souvent l'adoption de contre-mesures dans le cadre de l'accord qui a été violé par un membre donné de l'OMC. La suspension de concessions ou d'autres obligations se rapportant à un accord de l'OMC différent de celui qui a été violé s'appelle rétorsion croisée. Dans ce contexte, la rétorsion croisée en propriété intellectuelle (TRIPS) peut apparaître comme une option pour les pays en développement, quand ceux-ci sont parties à une dispute contre les pays développés à l’OMC. Ceci ressort de l'importance que représente la propriété intellectuelle pour l'économie des pays développés. La rétorsion croisée en propriété intellectuelle a été autorisée seulement en trois cas, parmis les plus de 460 qui existent à l'OMC: EC - Bananas III (DS27), US Gambling (DS265) e US - Cotton (DS267). La dernière de ces disputes, le contentieux du coton, se rapporte à une demande du Brésil contre les États-Unis. Bien qu'autorisé dans ces trois précédents, le mécanisme n’a jamais été appliqué. Face à ce scenario, la présente thèse analyse de manière multidisciplinaire, en tenant compte des précédents mentionnés, si l'autorisation pour appliquer la rétorsion croisée en propriété intellectuelle conduit au respect des décisions prises par l'Organe de Règlement des Différends de l'OMC. Cette vérification considère les défis d'appliquer la rétorsion croisée en propriété intellectuelle et les effets de la menace de l'utilisation du mecanisme sur les négociations. En ce qui concerne les negociations, il est fondamental considérer l'intéraction qui a lieu entre les secteurs public et privé des deux pays impliqués dans un différend donné. Cette influence mutuelle entre les secteurs doit être comprise à la lumière de la théorie des jeux à deux niveaux, également analysée dans cette étude.

Mots-clés: Organisation Mondiale du Commerce (OMC); système de règlement de différends; rétorsion croisée; propriété intellectuelle; théorie des jeux à deux niveaux; négociations internationales; contentieux du coton. 


\section{SUMÁRIO}

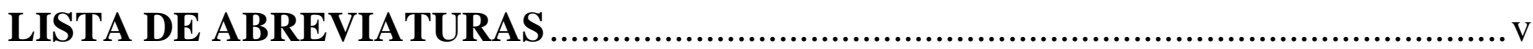

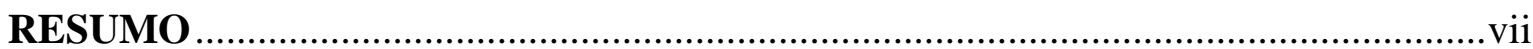

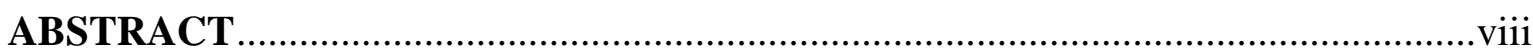

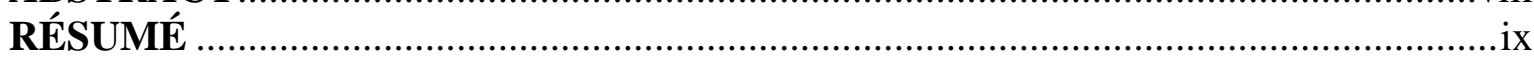

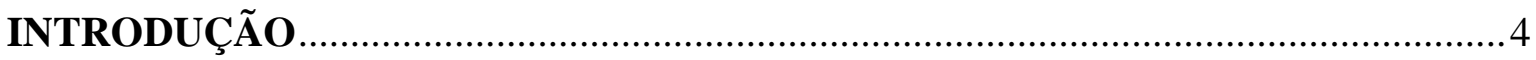

1. ORGANIZAÇÃO MUNDIAL DO COMÉRCIO (OMC) ..................................

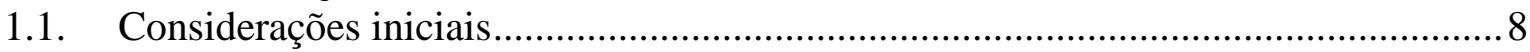

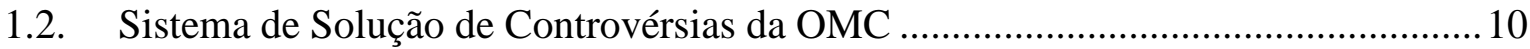

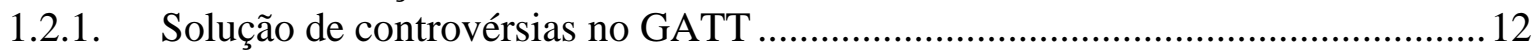

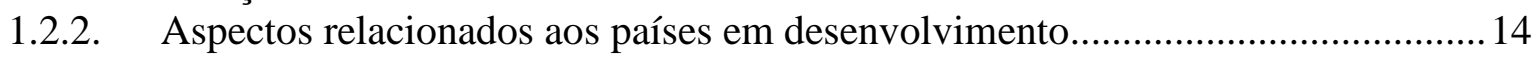

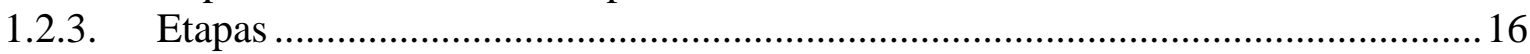

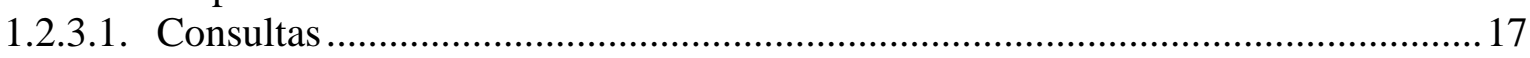

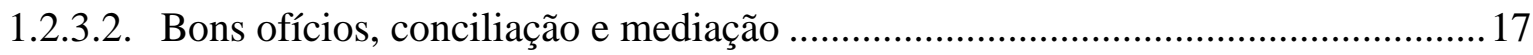

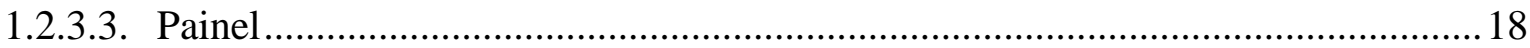

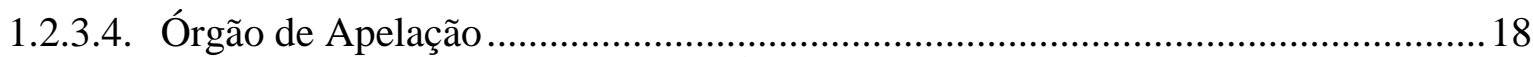

1.2.3.4.1. Recomendações do painel e do Órgão de Apelação..........................................19

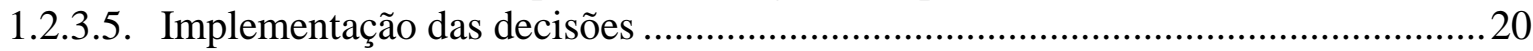

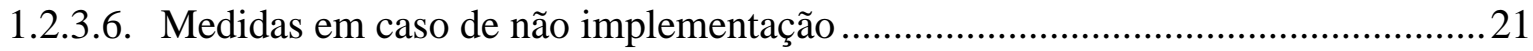

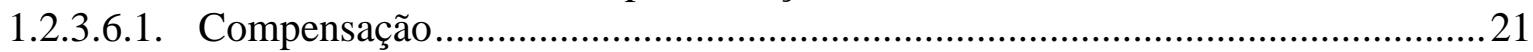

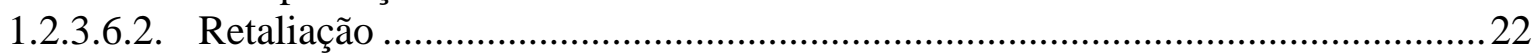

1.2.3.6.2.1. Dificuldades dos países em desenvolvimento de aplicar a retaliação ............23

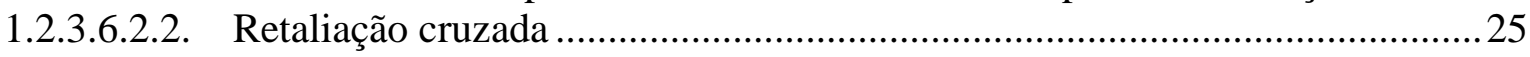

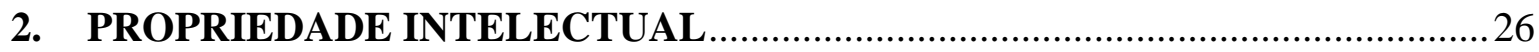

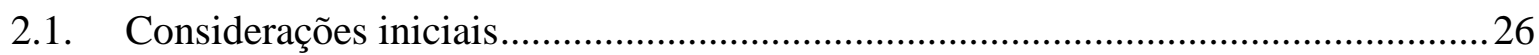

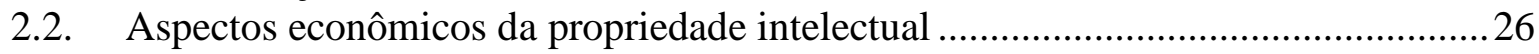

2.3. Impactos da propriedade intelectual sobre o Direito Internacional ...........................28

2.3.1. A propriedade intelectual no comércio internacional ...........................................29

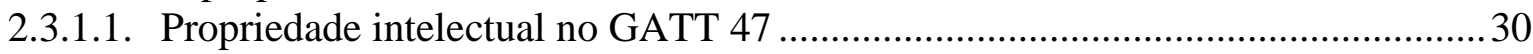

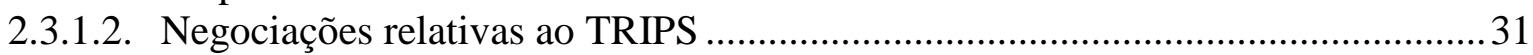

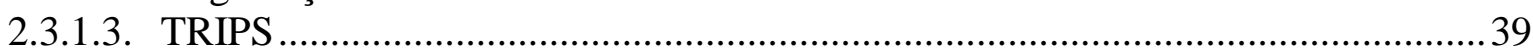

\section{PRECEDENTES DA RETALIAÇÃO CRUZADA EM PROPRIEDADE}

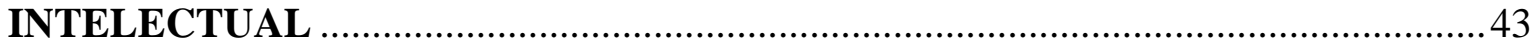

3.1. Retaliação cruzada em propriedade intelectual ......................................................43

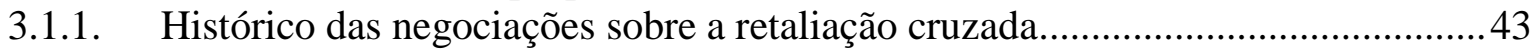

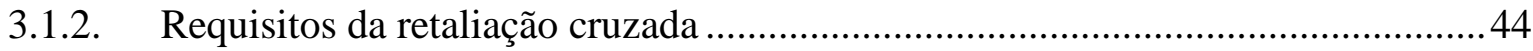

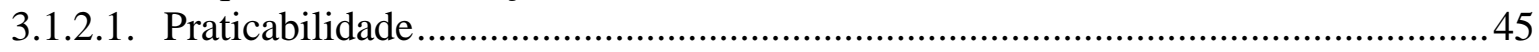

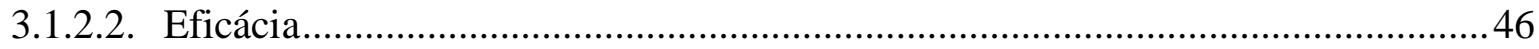

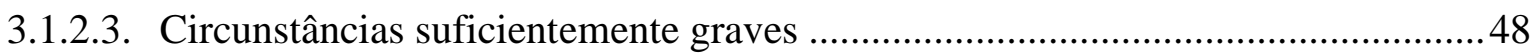

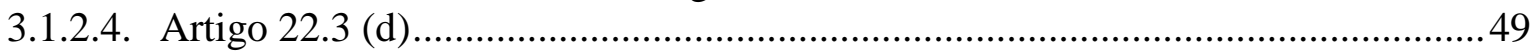

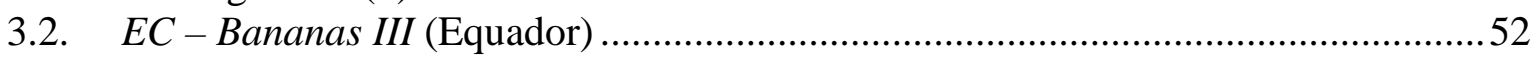

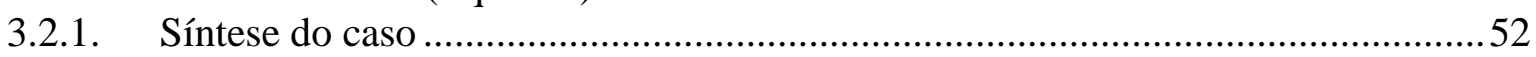

3.2.2. Pedido de retaliação cruzada em propriedade intelectual ....................................53 


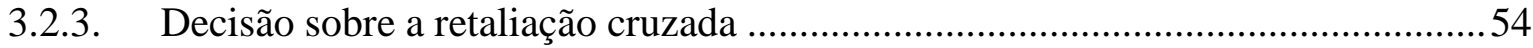

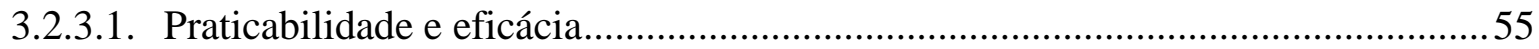

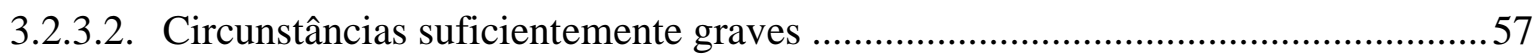

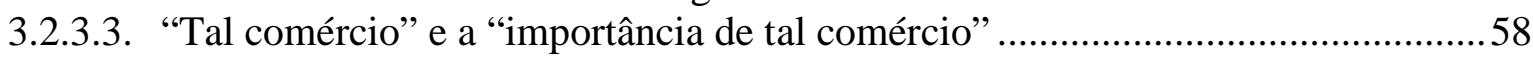

3.2.3.4. Consequências e elementos econômicos mais gerais............................................59

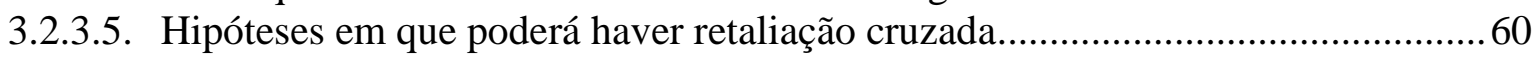

3.2.3.6. Considerações sobre a aplicação da retaliação em propriedade intelectual ...........61

3.2.3.6.1. Efeitos da retaliação cruzada sobre terceiros países ...........................................62

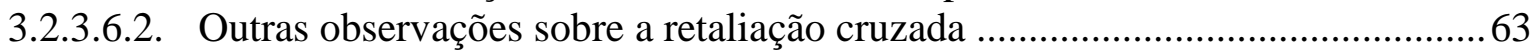

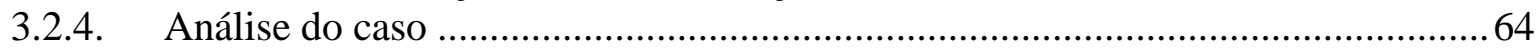

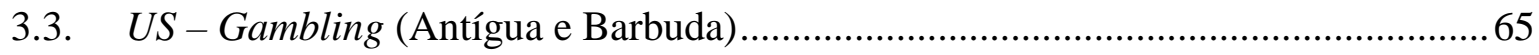

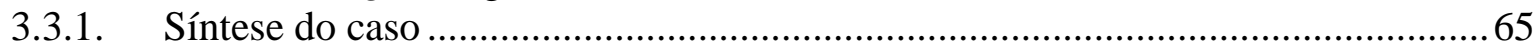

3.3.2. Pedido de retaliação cruzada em propriedade intelectual .....................................66

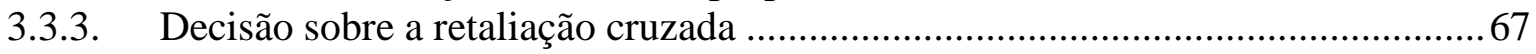

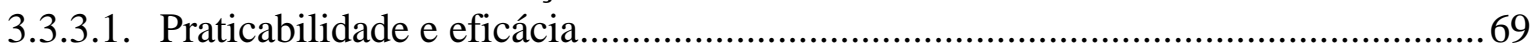

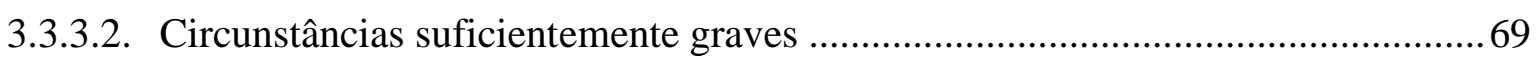

3.3.3.3. “Tal comércio” e a "importância de tal comércio” ................................................ 71

3.3.3.4. Consequências e elementos econômicos mais gerais........................................... 71

3.3.3.5. Considerações sobre a implantação da retaliação cruzada....................................... 72

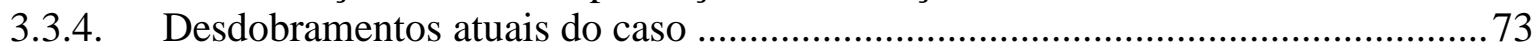

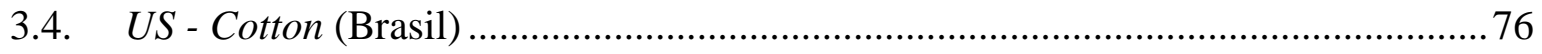

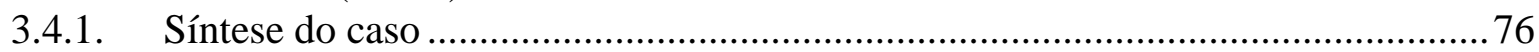

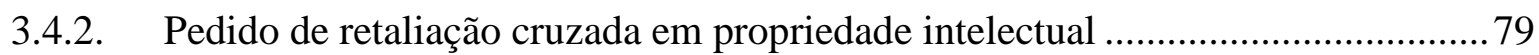

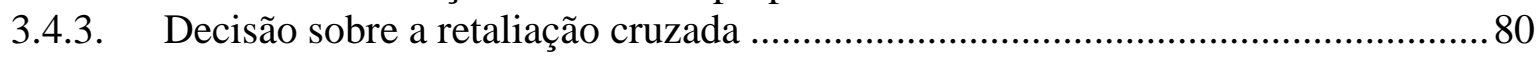

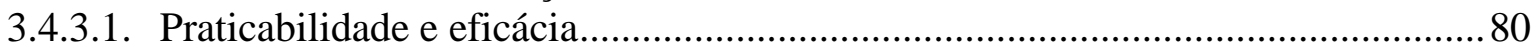

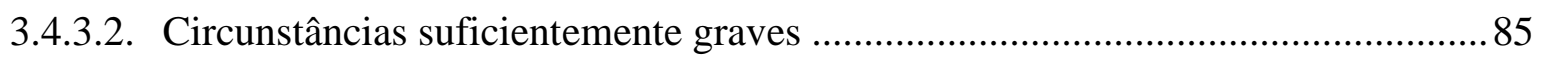

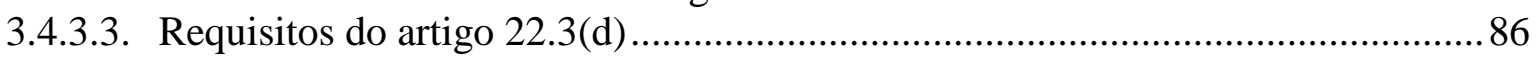

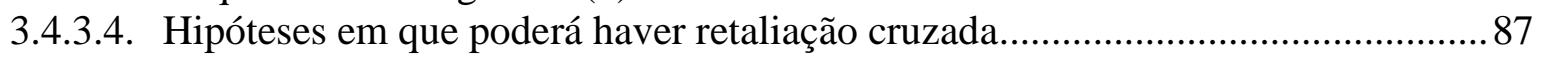

3.4.4. Desdobramentos da disputa após a autorização da OMC para retaliar ...................88

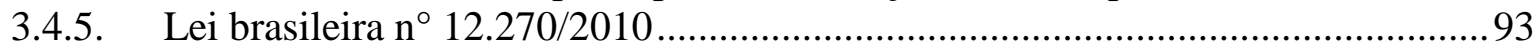

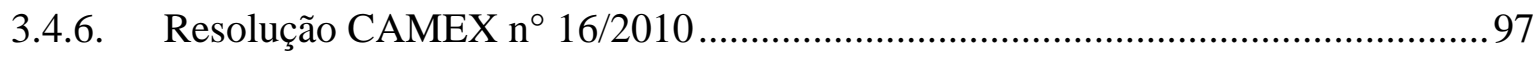

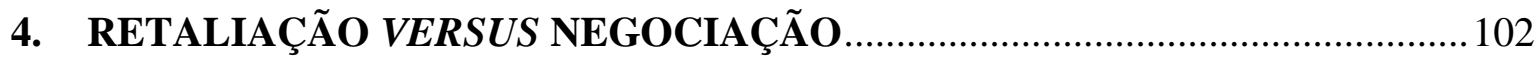

4.1. Dificuldades inerentes à retaliação cruzada em propriedade intelectual .................102

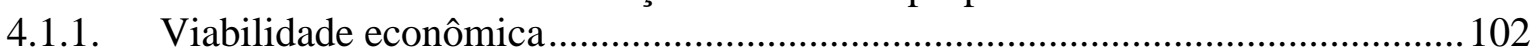

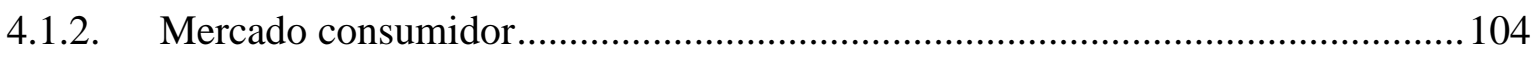

4.1.3. Montante autorizado de suspensão dos direitos de propriedade intelectual ........105

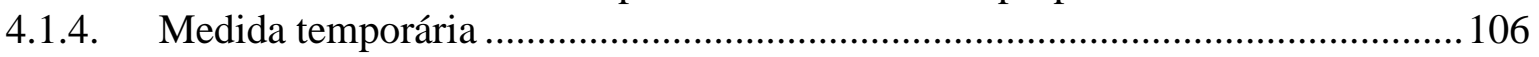

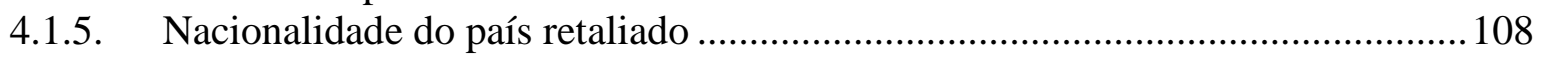

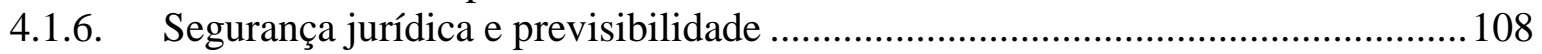

4.1.7. Impactos da retaliação cruzada sobre direitos privados ....................................109

4.1.8. Compromissos internos e internacionais do retaliante.........................................109

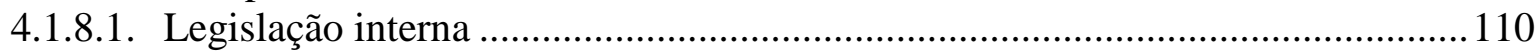

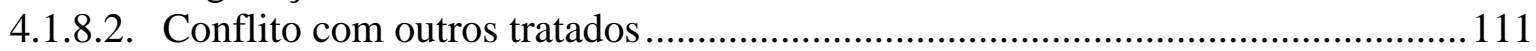

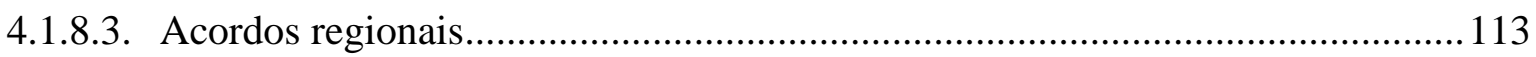

4.2. Possibilidades para a implementação da retaliação cruzada em propriedade

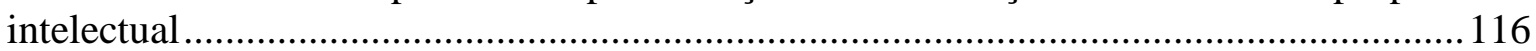

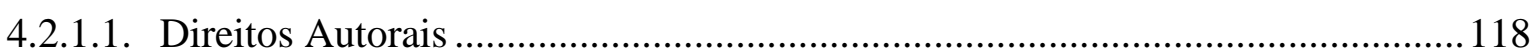

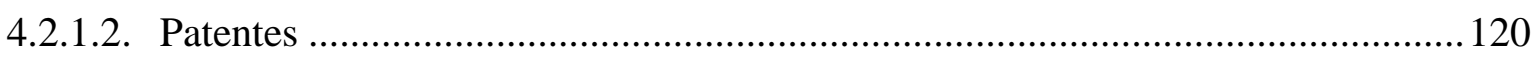

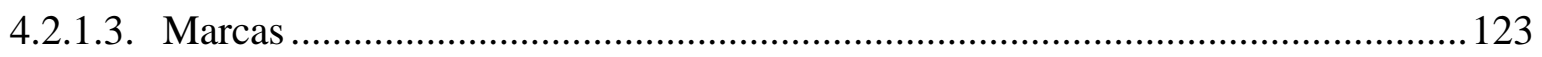


4.3. Negociações ................................................................................................. 124

4.3.1. Teoria dos jogos de dois níveis: interação entre setores público e privado .........125

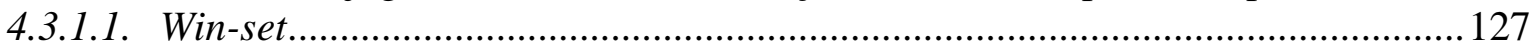

4.3.1.2. Ameaça: uma estratégia de barganha? .................................................................. 130

4.3.1.3. Teoria dos jogos de dois níveis no contencioso do algodão ................................132

4.3.1.3.1. A interação entre os setores público e privado nos Estados Unidos .................133

4.3.1.3.2. Aspectos econômicos do algodão.......................................................................133

4.3.1.3.3. Aspectos políticos do setor cotonicultor............................................................134

4.3.1.3.4. A organização política da indústria do algodão ..................................................135

4.3.1.3.5. Sistema eleitoral .......................................................................................135

4.3.1.3.6. Doações financeiras para campanhas eleitorais .................................................136

4.3.1.3.7. Perspectivas de alteração da Farm Bill ...........................................................137

4.3.1.3.8. Brazil Trade Action Coalition (BRAZTAC) ...................................................139

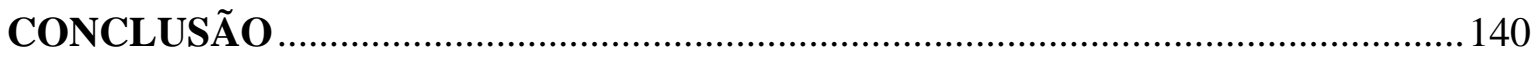

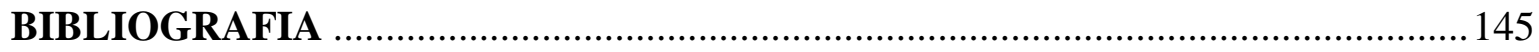




\section{INTRODUÇÃO}

O cenário atual, em que há significativa redução das barreiras comerciais aliada ao aumento das facilidades de comunicação e transporte, culminou com a intensificação do comércio e aumento da interdependência econômica entre os países. Neste contexto é importante destacar o papel desempenhado pela Organização Mundial do Comércio (OMC), que atualmente possui mais de 150 membros $^{1}$. A uniformização de regras, promovida pela OMC, é essencial para facilitar o comércio internacional. Ademais, essa organização possui um sistema de solução de controvérsias regulado pelo Entendimento Relativo às Normas e Procedimentos sobre Soluções de Controvérsias (ESC) ${ }^{2}$, que tem como função assegurar os direitos e obrigações previstos nos acordos desta organização internacional. $^{3}$

Uma das etapas do sistema de solução de controvérsias da OMC corresponde à implementação da decisão do painel ou do Órgão de Apelação. Caso não se verifique o cumprimento, as partes podem acordar compensação ou a parte prejudicada pode requerer ao Órgão de Solução de Controvérsias (OSC) a suspensão de concessões ou outras obrigações, nos termos do artigo 22.3 do ESC. ${ }^{4}$ Esse processo é denominado retaliação.

Nesse sentido, se houver necessidade, é possível que ocorra a retaliação entre Estados membros no âmbito do sistema de solução de controvérsias da OMC. Contudo, a retaliação deve respeitar uma ordem. ${ }^{5}$ Primeiramente, deve-se buscar retaliar no mesmo setor em que ocorreu a disputa. Em seguida, pode-se retaliar por meio de outro setor, mas no âmbito do mesmo acordo da OMC. Por fim, se necessário, pode ser requerida a retaliação por meio de outro acordo da OMC, conhecida como retaliação cruzada, objeto de estudo desta dissertação. Assim, somente em situações específicas e mediante autorização do OSC a parte poderá aplicar a retaliação cruzada.

\footnotetext{
${ }^{1}$ Lista de membros da OMC disponível em: <www.wto.org/english/thewto_e/whatis_e/tif_e/org6_e.htm>. Acesso em 11/08/2013.

2 Disponível em: <www.itamaraty.gov.br/o-ministerio/conheca-o-ministerio/tecnologicos/cgc/solucao-decontroversias/mais-informacoes/texto-dos-acordos-da-omc-portugues/2-anexo-2-entendimento-relativo-asnormas-e-procedimentos-sobre-solucao-de-controversias/view >. Acesso em 12/08/2013.

${ }^{3}$ Conforme o artigo 3.2 do ESC.

4 ESC, Artigo 22.3. “Ao considerar quais concessões ou outras obrigações serão suspensas, a parte reclamante aplicará os seguintes princípios e procedimentos: (...) (c) se a parte considera que é impraticável ou ineficaz suspender concessões ou outras obrigações relativas a outros setores abarcados pelo mesmo acordo abrangido, e que as circunstâncias são suficientemente graves, poderá procurar suspender concessões ou outras obrigações abarcadas por outro acordo abrangido; (...)”

${ }^{5}$ Prevista no artigo 22.3 do ESC.
} 
Em razão do caráter excepcional da retaliação cruzada, dos mais de 460 casos $^{6}$ levados à OMC, em apenas três deles foi autorizada a utilização desse mecanismo em propriedade intelectual. ${ }^{7}$ No primeiro deles, EC - Bananas III (DS27), o Equador recebeu autorização para aplicar a retaliação cruzada em propriedade intelectual contra a União Europeia. Na controvérsia relativa a jogos de azar (US - Gambling - DS265), Antígua e Barbuda (“Antígua”) pôde utilizar o mecanismo em face dos Estados Unidos. E a autorização mais recente dessa modalidade de retaliação corresponde ao caso US - Cotton (DS267), em que o Brasil foi autorizado a usar a ferramenta contra os Estados Unidos. Como o presente estudo será realizado a partir de uma perspectiva brasileira, torna-se mais relevante o último dos três precedentes mencionados.

Deve-se ter em vista que os três membros da OMC que obtiveram a possibilidade de utilizar essa ferramenta (Equador, Antígua e Brasil) são países em desenvolvimento em face de países desenvolvidos, ou seja, havia disparidade econômica significativa entre as partes da controvérsia. Cumpre elucidar que embora o Brasil seja considerado emergente ${ }^{8}$ na economia internacional, ainda tem um poder econômico muito inferior aos Estados Unidos, país com quem disputa o contencioso do algodão na OMC. Além disso, o Brasil é considerado um país em desenvolvimento na classificação da OMC. ${ }^{9}$

Até o momento, em nenhum dos casos houve a implementação do mecanismo em questão. Diante desse fato, a principal questão abordada por esta dissertação é se a autorização para aplicar a retaliação cruzada em propriedade intelectual induz o cumprimento de decisões adotadas pelo Órgão de Solução de Controvérsias da OMC. Caso haja efetivo cumprimento da decisão, tanto a parte vencedora quanto o próprio sistema multilateral de comércio serão beneficiados. Essa análise será feita da perspectiva dos países em desenvolvimento em face de países desenvolvidos, à luz dos três precedentes na OMC.

\footnotetext{
${ }^{6}$ Lista de casos disponível em: <www.wto.org/english/tratop_e/dispu_e/find_dispu_cases_e.htm\#results>. Acesso em 11/08/2013.

${ }^{7}$ Embora a retaliação cruzada apresente diversas hipóteses, como serviços, bens e propriedade intelectual, dependendo do caso concreto, o foco do presente trabalho é a retaliação cruzada em propriedade intelectual. Nesse contexto, destaca-se que, em dezembro de 2011, os Estados Unidos solicitaram autorização para aplicar retaliação cruzada em serviços em face da União Europeia, no caso EC and certain member States Large Civil Aircraft (DS316). Tendo em vista que o pedido refere-se somente à retaliação cruzada em serviços e não envolve propriedade intelectual, o caso não será analisado nesta dissertação.

${ }^{8}$ A respeito, vide WILLIAMS, Sean. Why Is Brazil an Emerging Market Economy?. The University of Iowa Center of International Finance and Development. Disponível em: <ebook.law.uiowa.edu/ebook/uicifdebook/why-brazil-emerging-market-economy $>$. Acesso em 11/08/2013.

${ }^{9}$ THORSTENSEN, Vera. OMC: Organização Mundial do Comércio: as regras do comércio internacional e a nova rodada de negociações multilaterais. $2^{\mathrm{a}}$ ed., São Paulo: Aduaneiras, 2001, p. 229.
} 
Aspectos subsidiários decorrem desta problemática, incluindo: (i) principais desafios na implementação da retaliação cruzada em propriedade intelectual; (ii) efeitos da autorização da retaliação cruzada sobre as negociações internacionais; (iii) escolha entre negociação e retaliação; (iv) vantagens e dificuldades das negociações. O exame desses pontos perpassa a consideração dos prejuízos e benefícios para o país que aplica esse tipo de retaliação, bem como quais as perdas para o país alvo dessa medida.

O tema selecionado exige uma abordagem multidisciplinar, envolvendo a análise de aspectos jurídicos, econômicos e políticos. Desse modo, as negociações entre os países envolvidos em determinado contencioso serão analisadas à luz da teoria dos jogos de dois níveis, a qual se refere à interação entre os setores público e privado. O uso dessa teoria justifica-se na medida em que as indústrias que dependem dos direitos de propriedade intelectual pressionam os governos de países desenvolvidos a celebrarem acordos em caso de ameaça de retaliação cruzada em propriedade intelectual.

Ante o exposto, cumpre elucidar a composição e estrutura deste trabalho. O método utilizado foi o indutivo, pois se buscou formular uma regra geral por meio da análise dos precedentes de retaliação cruzada em propriedade intelectual. Além do uso de referências bibliográficas e documentos oficiais (principalmente da OMC), foram realizadas entrevistas com atores-chave na disputa US - Cotton, do governo brasileiro e do setor privado de ambos os países. Tais entrevistas, realizadas a partir de um questionário estruturado, foram fundamentais para compreender a dinâmica das negociações, já que a estratégia da política comercial dos países na maioria das vezes não está presente nos livros. Além desta introdução e da conclusão, a presente dissertação está estruturada em quatro capítulos, descritos a seguir.

O primeiro capítulo trará aspectos mais gerais sobre o sistema multilateral de comércio. Serão salientados as regras e o funcionamento do sistema de solução de controvérsias, com breve diferenciação de suas etapas para, em seguida, demonstrar em que casos é possível solicitar autorização ao OSC para aplicar a retaliação cruzada. Essa análise deve-se à necessidade de demonstrar que apenas após ultrapassadas determinadas etapas e mediante o cumprimento de certos requisitos é possível ocorrer a retaliação cruzada.

Já o segundo capítulo explorará o tema da propriedade intelectual, demonstrando sua importância na economia e no comércio, além de evidenciar os principais setores interessados na proteção dos direitos de propriedade intelectual. Tal análise é essencial para o capítulo final, quando será debatida a teoria dos jogos de dois 
níveis, a qual retrata a influência recíproca entre setores público e privado nas negociações internacionais. Para isso, torna-se importante apresentar breve histórico das negociações, bem como os principais aspectos do acordo TRIPS (Trade-Related Aspects of Intellectual Property Rights).

O terceiro capítulo, por sua vez, analisará os três precedentes da retaliação cruzada em propriedade intelectual: EC - Bananas III, US - Gambling e US - Cotton, sendo que no último caso o Brasil figura como retaliante. Até o momento, em nenhum dos três casos ocorreu efetivamente a retaliação, mas cabe ressaltar que as disputas US Gambling e US - Cotton ainda não foram concluídas. Em outras palavras, a retaliação cruzada não foi descartada. A importância da análise dos precedentes está na interpretação dos requisitos da retaliação cruzada, instrumento que poderá ser utilizado posteriormente por outros países.

Por fim, o quarto capítulo sopesará as vantagens e desvantagens da retaliação cruzada em propriedade intelectual em contraposição a uma solução negociada entre as partes em disputa. Isso ocorrerá por meio da verificação dos principais desafios e vantagens tanto da negociação como da retaliação em questão. Para fazer essa avaliação, torna-se importante compreender qual é o poder de barganha que a autorização para aplicar a retaliação cruzada em propriedade intelectual na OMC concede a um país em desenvolvimento em face de um país desenvolvido. Esta assertiva está relacionada ao interesse do setor privado, que pressiona os Estados na defesa de seus interesses. Essa interação entre os setores público e privado no âmbito de uma negociação internacional remete à teoria dos jogos de dois níveis, a qual também será detalhadamente analisada. Após tal estudo, será possível apontar algumas possibilidades para o Brasil no contencioso US-Cotton. 


\section{ORGANIZAÇÃO MUNDIAL DO COMÉRCIO (OMC)}

O presente capítulo contém um panorama geral da OMC, com destaque para o seu sistema de solução de controvérsias. A compreensão das regras da Organização, sobretudo do ESC, é fundamental para a análise da retaliação cruzada, que é um dos mecanismos disponíveis em caso de não cumprimento das decisões do OSC. Este capítulo demonstrará as etapas que devem ser seguidas antes de solicitar autorização à OMC para aplicar a retaliação cruzada em propriedade intelectual.

\subsection{Considerações iniciais}

A ideia de estabelecer uma organização internacional para desenvolver e coordenar o comércio internacional surgiu em 1944, na Conferência de Bretton Woods. Contudo, apenas em 1946 foi adotada uma resolução favorável à criação da Organização Internacional do Comércio (OIC). As negociações da OIC ocorriam paralelamente à elaboração de um tratado multilateral, contendo princípios gerais de comércio e reduções tarifárias, o General Agreement on Tariffs and Trade (GATT). ${ }^{10} 11$

Com o intuito de usufruir das diminuições de tarifas sem aguardar a conclusão das negociações sobre a OIC, foi definido que o GATT entraria em vigor de forma provisória e posteriormente seria ajustado de acordo com a OIC. ${ }^{12}$ Porém, o terceiro ${ }^{13}$ pilar da Conferência de Bretton Woods, a OIC, não foi bem-sucedido devido à rejeição do Congresso dos Estados Unidos ${ }^{14}$ e à consequente não adesão de outros países.

A ausência de uma vertente comercial em Bretton Woods fortaleceu a função do GATT. ${ }^{15}{ }^{16}$ Desse modo, o GATT, que era provisório e não tinha personalidade jurídica, perdurou por muitos anos, até a oitava rodada de negociação do GATT, que resultou na criação da OMC.

10 MATSUSHITA, Mitsuo; SCHOEnBAUM, Thomas J.; MAVROIDIS, Petros C. The World Trade Organization: Law, Practice and Policy. New York : Oxford International Law Library, 2003, p. 1-2.

${ }^{11}$ Conhecido também como GATT 47, para diferenciá-lo do acordo GATT vigente na OMC (que entrou em vigor apenas em 1995).

12 MATSUSHITA, Mitsuo; SCHOENBAUM, Thomas J.; MAVROIDIS, Petros C. The World Trade Organization: Law, Practice and Policy, p. 1-2.

${ }^{13}$ Os dois outros pilares correspondem ao Fundo Monetário Internacional (FMI) e ao Banco Mundial.

14 JACKSON, John H. Perceptions about the WTO trade institutions. In: World Trade Review, v. 1, n. 1, 2002, p. 104.

15 JACKSON, John H. The Changing Fundamentals of International Law and Ten Years of the WTO. In: Journal of International Economic Law, v. 8, n. 1, 2005, p. 3.

${ }^{16}$ A criação do GATT teve respaldo também no cenário político interno dos Estados Unidos, especificamente a Constituição desse país e a competência delegada ao presidente. Nesse sentido, vide JACKSON, John H. Perceptions about the WTO trade institutions, p. 104. 
A intensificação do comércio após a Segunda Guerra Mundial, mormente depois da Guerra Fria, acarretou a necessidade de aprimorar a regulamentação nessa área, o que ensejou a criação da OMC. Em relação ao contexto político e econômico em que surgiu a OMC, é interessante notar que seu sucesso advém parcialmente da situação existente no mundo após a Guerra Fria, que cedeu lugar ao multilateralismo. ${ }^{17}$

De fato, a partir de 1980, os países em desenvolvimento iniciaram um processo de abertura econômica e de liberalização do comércio. Tais fatores aumentaram a participação desses países na OMC. Cumpre elucidar que cada país pode se definir como “em desenvolvimento" ou “desenvolvido"18, embora a OMC reconheça a lista da Organização das Nações Unidas (ONU) de países de menor desenvolvimento relativo. ${ }^{19}$

Embora as sete rodadas de negociações do GATT, ocorridas entre 1947 e 1979 tenham sido bem-sucedidas, a alteração de condições do mercado, incluindo a existência de barreiras não tarifárias, pressionavam para a criação de novas regras. ${ }^{20}$ Desse modo, surgiu a Rodada Uruguai, em 1986, que tinha previsão de três anos de duração. No entanto, a incorporação de diversos objetivos na pauta de negociações prorrogou o prazo para conclusão, que somente ocorreu em 1994. Sua conclusão restou atestada em 26.000 páginas de regras, englobando novos temas, incluindo propriedade intelectual e serviços. ${ }^{21}$ Houve também uma reformulação do sistema de solução de controvérsias do GATT. Assim, após 47 anos da aplicação “provisória” do GATT, foi estabelecida a primeira organização mundial do comércio, que completou o sistema da Conferência de Bretton Woods de $1944 .^{22}$

Estabelecida em 1995, a OMC atualmente possui 159 países membros ${ }^{23}$ Não obstante os membros da OMC sejam Estados, os interesses privados permeiam a Organização, já que o assunto tratado é o mercado. Porém, os governos precisam encontrar um "interesse nacional" 24 para levar o assunto à OMC.

${ }^{17}$ LAFER, Celso. A OMC e a regulamentação do comércio internacional: uma visão brasileira. Porto Alegre: Livraria do Advogado, 1998, p. 108.

18 THORSTENSEN, Vera. OMC: Organização Mundial do Comércio: as regras do comércio internacional e a nova rodada de negociações multilaterais, p. 229.

${ }^{19}$ Referida lista pode ser obtida em < www.un.org/special-rep/ohrlls/ldc/list.htm>. Acesso em 14/04/2013.

${ }^{20}$ JACKSON, John H. The Law and Ten Years of the WTO. In: Journal of International Economic Law, v. 8, n. 1, 2005, p. 4.

${ }^{21}$ BARRAL, Welber. De Bretton Woods a Seattle. In: BARRAL, Welber (org.). O Brasil e a OMC: os interesses brasileiros e as futuras negociações multilaterais. Florianópolis: Diploma Legal, 2000, p. 25.

22 JACKSON, John H. The Changing Fundamentals of International Law and Ten Years of the WTO, p. 4.

${ }^{23}$ Disponível em <www.wto.org>. Acesso em 12/08/2013.

${ }^{24}$ LAFER, Celso. A OMC e a regulamentação do comércio internacional: uma visão brasileira, p. 115. 
A Organização em referência é baseada, dentre outros, nos seguintes princípios: (i) nação mais favorecida: qualquer vantagem, favor, privilégio ou imunidade que afete direitos aduaneiros ou outras taxas que são concedidos a uma parte contratante deve ser estendido a produtos similares comercializados com outra parte contratante ${ }^{25}$; (ii) tratamento nacional: essa regra veda a discriminação entre produtos nacionais e importados, após a internalização das mercadorias.

Na Rodada Uruguai, definiu-se que uma condição para se tornar membro da organização internacional remetia ao “single undertaking”, isto é, os membros deveriam aceitar os acordos da OMC como um conjunto não dissociável ${ }^{26}$. C. LAFER defende que isso “outorgou efetividade jurídica à 'codificação e desenvolvimento progressivo do direito econômico internacional público' da Rodada do Uruguai, posto que lhe conferiu a natureza de um ordenamento jurídico unificado"27.28

Assim, no acordo constitutivo da OMC consta que os anexos $1^{29}, 2^{30}$ e $3^{31} 32$ são obrigatórios a todos os membros, enquanto os acordos plurilaterais obrigam apenas seus signatários. Dentre outras funções, a OMC corresponde a um foro de negociações sobre temas relativos ao comércio internacional, provida de um sistema de solução de controvérsias para dirimir disputas oriundas de seus acordos. O próximo tópico será dedicado ao estudo do sistema de solução de controvérsias.

\subsection{Sistema de Solução de Controvérsias da OMC}

O cumprimento dos acordos da OMC é resguardado pelo Entendimento Relativo às Normas e Procedimentos sobre Soluções de Controvérsias (ESC), o qual integra o sistema de solução de controvérsias da referida organização. Tal sistema almeja

\footnotetext{
25 THORSTENSEN, Vera. OMC: Organização Mundial do Comércio: as regras do comércio internacional e a nova rodada de negociações multilaterais, p. 33.

${ }^{26}$ Idem, p. 41.

${ }^{27}$ LAFER, Celso. A OMC e a regulamentação do comércio internacional: uma visão brasileira, p. 23.

${ }^{28}$ A consequente unidade do sistema decorrente do princípio do "single undertaking" também é defendida em BASSO, Maristela. O Regime Internacional de Proteção da Propriedade Intelectual da OMC/Trips. In: AMARAL JÚNIOR, Alberto do (coord.). A OMC e o comércio internacional. São Paulo: Aduaneiras, 2002, p. 135-136.

${ }^{29} 1 \mathrm{~A}$ corresponde ao GATT; 1B, ao GATS; e 1C ao TRIPS.

${ }^{30}$ Entendimento Relativo às Normas e Procedimentos sobre Soluções de Controvérsias (ESC).

${ }^{31}$ Trade Policy Review Mechanism (Mecanismo de Revisão da Política Comercial).

32 O Brasil ratificou os acordos em referência por meio do Decreto n. 1.355 de 30/12/94. Disponível em: <www.planalto.gov.br/ccivil_03/decreto/Antigos/D1355.htm>. Acesso em 08/08/2013.
} 
garantir segurança e previsibilidade no comércio internacional ${ }^{33}$, características essenciais para o funcionamento adequado do mercado. ${ }^{34}$ Sobre o tema, assevera C. LAFER:

É precisamente para evitar o unilateralismo político de interpretação e conter o self help na sua aplicação por meio de "retorsões" e "represálias comerciais" que o sistema multilateral de solução de controvérsias da OMC foi concebido, enquanto um mecanismo rule oriented, na linha grociana, destinado a "domesticar" as tendências unilaterais das "razões de estado" power oriented. ${ }^{35}$

A mudança de um mecanismo power oriented para rule oriented, mencionado acima, não ocorre apenas na OMC, já que acompanha as modificações da civilização. ${ }^{36}$ Apesar disso, é importante destacar que não se alcançou o extremo, isto é, o sistema da OMC não é totalmente jurídico. A influência da política e do poder econômico de grandes potências pode ser observada tanto nas negociações das regras como na conclusão das controvérsias.

O sistema de solução de controvérsias na OMC pauta-se em três características: abrangência, automaticidade e exequibilidade de suas decisões. Abrangência por englobar todos os acordos da OMC e por ser o único mecanismo com essa finalidade, evitando o forum shopping. A automaticidade (ou semi-automaticidade, como defendem alguns autores) decorre da regra do consenso negativo, detalhada no item abaixo. Já a exequibilidade remete à possibilidade de um membro demandante solicitar, consoante as regras, autorização para retaliar outro membro que descumprir as normas da OMC. ${ }^{37}$

O sistema de solução de controvérsias da OMC zela pelo cumprimento de suas normas. Nesse sentido, J. PAUWELYN assevera que“(...) the WTO - in particular, the elaborate enforcement provisions of the ESC - is a step ahead of the ICJ and other international enforcement mechanisms, and provides one of the most developed enforcement regimes in international law”. ${ }^{38}$

Um dos fatores que explica a eficácia do sistema em questão remete ao fato de que os painéis da OMC possuem jurisdição compulsória sobre todas as disputas entre os membros relativas aos acordos da referida Organização. Ademais, os procedimentos

\footnotetext{
${ }^{33}$ Artigo 3.2 do ESC.

34 JACKSON, John H. The case of the World Trade Organization. In: International Affairs, v. 84, n. 3, 2008, p. 438.

${ }^{35}$ LAFER, Celso. A OMC e a regulamentação do comércio internacional: uma visão brasileira, p. 110-111.

${ }^{36}$ JACKSON, John H. The case of the World Trade Organization. In: International Affairs, p. 440.

${ }^{37}$ PRADO, Victor Luiz do. Mecanismo de Solução de Controvérsias: Fonte de Poder e de Problemas na OMC. In: AMARAL JÚNIOR, Alberto do (coord.). A OMC e o comércio internacional. São Paulo: Aduaneiras, 2002, p. 265-266.

${ }^{38}$ PAUWELYN, Joost. Enforcement and Countermeasures in the WTO: Rules are Rules - Toward a More Collective Approach. In: American Journal of International Law, v. 94, 2000, p. 339.
} 
estabelecidos pelo ESC são consideravelmente mais detalhados do que os existentes em outras organizações internacionais. Poucos sistemas de solução de controvérsias internacionais possuem órgão de apelação e o número de entidades que estabelecem um mecanismo de monitoramento ${ }^{39}$ do cumprimento das decisões é ainda menor. ${ }^{40}$

O sistema de solução de controvérsias atual pauta-se no antigo mecanismo do GATT. Nesse contexto, o artigo 3.1 do ESC prevê: “Os Membros afirmam sua adesão aos princípios de solução de controvérsias aplicados até o momento com base nos Artigos 22 e 23 do GATT 1947 e ao procedimento elaborado e modificado pelo presente instrumento”. Desse modo, torna-se importante compreender as práticas adotadas no GATT, bem como uma breve comparação entre os dois sistemas em questão.

\subsubsection{Solução de controvérsias no GATT}

O sistema de solução de controvérsias da OMC é resultado de mais de 40 anos de experiência da solução de disputas no âmbito do GATT. ${ }^{41}$ Nesse sentido, cabe esclarecer as principais semelhanças e diferenças entre ambos os mecanismos.

No início do GATT, as disputas eram solucionadas por procedimentos diplomáticos. A partir de 1955, o grupo de trabalho composto por representantes dos países membros cedeu lugar a um painel formado por especialistas. ${ }^{42}$ Nesse sentido, nota-se que:

O panel, no sistema GATT, representou, portanto, em primeiro lugar, uma instância independente - uma third-party - um tertius. Este tertius não se coloca entre as partes - como na mediação ou na conciliação. Coloca-se entre e acima das partes, não por delegação, como na arbitragem, mas de forma autorizada pelo sistema, como um juiz, numa solução judicial. (...) A inclusão do tertius, de maneira institucionalizada, despolitizava a situação e o processo de qualificação jurídica dos fatos. ${ }^{43}$

A figura do painel composto por especialistas foi mantida pela OMC. Todavia, desde a criação da entidade existe a possibilidade de recorrer ao Órgão de Apelação, instituto inexistente no GATT, que contribuiu para tornar o procedimento mais jurídico.

No GATT, o painel elaborava seu relatório e entregava ao Conselho. Em seguida, o documento tornava-se obrigatório apenas se o relatório fosse aprovado por consenso. Todavia, para obter esse consenso, era necessário que todos os membros

${ }^{39} \mathrm{O}$ dispositivo que estabelece o monitoramento do cumprimento das partes no tocante às recomendações do painel e do Órgão de Apelação corresponde ao artigo 21.6 do ESC.

${ }^{40}$ VÁZQUEZ, Carlos M.; JACKSON, John H. Some Reflections of Compliance with WTO Dispute Settlement Decisions. In: Law and Policy in International Business, v. 33, n. 4, 2002, p. 562.

41 MATSUSHITA, Mitsuo ; SCHOENBAUM, Thomas J.; MAVROIDIS, Petros C. The World Trade Organization : Law, Practice and Policy, p. 19.

42 JACKSON, John H. The case of the World Trade Organization. In: International Affairs, p. 442.

${ }^{43}$ LAFER, Celso. A OMC e a regulamentação do comércio internacional: uma visão brasileira, p. 117-118. 
(inclusive o que perdeu a disputa) concordassem com o documento. Assim, o bloqueio (que poderia ser realizado pela parte que tivesse perdido a controvérsia) tornou-se um dos principais problemas da solução de controvérsias no GATT. ${ }^{44} 45$

Por outro lado, o sistema de solução de controvérsias da OMC adotou a regra do consenso negativo, isto é, o estabelecimento do painel, a adoção dos relatórios do painel e do Órgão de Apelação, bem como a autorização para retaliar ocorrem automaticamente, exceto se houver um consenso no sentido contrário. ${ }^{46}$ Portanto, as condições para efetividade e eficácia desse sistema são notáveis se comparadas ao antigo sistema vigente no GATT, em que vigorava a regra do consenso positivo.

Na OMC, a primeira medida em caso de não implementação de uma decisão ainda é a recomendação, como ocorria no GATT. A retaliação permanece como última alternativa, como no GATT. Todavia, apenas dois pedidos de retaliação ${ }^{47}$ foram realizados no GATT e ambos foram vetados. ${ }^{48}$ Já na OMC, foram 8 pedidos de retaliação até o momento. ${ }^{49}$ Tanto no GATT como na OMC não há compensação por prejuízos passados.

Ademais, no GATT, não havia um limite de tempo para um país que perdesse no sistema de solução de controvérsias se adequasse às normas. Assim, o processo poderia levar anos. Por outro lado, na OMC, há um limite, que em geral é de até 15 meses. $^{50}$

Outra diferença relevante está relacionada ao aumento da influência jurídica na OMC. Enquanto a OMC dispõe de um acordo (ESC) com 27 artigos apenas para lidar com a solução de litígios, no GATT $^{51}$ havia apenas dois artigos ${ }^{52}$ relativos à solução de controvérsias $^{53}$. A linguagem esparsa com poucos detalhes sobre objetivos e procedimentos da solução de controvérsias no GATT $^{54}$ contrapõe-se ao atual ESC.

\footnotetext{
44 JACKSON, John H. The case of the World Trade Organization. In: International Affairs, p. 443.

45 Até parte da década de 1980, o bloqueio também poderia ocorrer na constituição do painel. Após esse período, a medida tornou-se difícil de ser utilizada diplomaticamente. Nesse sentido, vide: JACKSON, John H. Dispute Settlement and the WTO: Emerging Problems. In: Journal of International Economic Law, v. 1, n. 3, 1998, p. 338.

${ }^{46}$ PAUWELYN, Joost. Enforcement and Countermeasures in the WTO: Rules are Rules - Toward a More Collective Approach, p. 336. O autor menciona os artigos 6.1, 16.4, 17.14 e 22.6 do ESC como exemplos.

${ }^{47}$ Ambos contra os Estados Unidos.

${ }^{48}$ HUDEC, Robert E. Broadening the Scope of Remedies in the WTO Dispute Settlement. In: WEISS, Friedl J. (ed.) Improving WTO Dispute Settlement Procedures: Issues and Lessons from the Practice of Other International Courts and Tribunals. London: Cameron, 2000, p. 353-354.

49 Disponível em: <www.wto.org/english/tratop_e/dispu_e/dispu_current_status_e.htm>. Acesso em 12/08/2013.

${ }^{50}$ HUDEC, Robert E. Broadening the Scope of Remedies in the WTO Dispute Settlement, p. 353-354.

51 Internalizado no Brasil por meio da lei n. 313, de 30 de julho de 1948. Disponível em: <www2.camara.leg.br/legin/fed/lei/1940-1949/lei-313-30-julho-1948-366722-publicacaooriginal-43528pl.html>. Acesso em 12/08/2013.

${ }^{52}$ Artigos XXII e XXIII.

53 JACKSON, John H. Dispute Settlement and the WTO: Emerging Problems, p. 332.

${ }^{54}$ Idem, p. 338.
} 
No GATT prevalecia um caráter político, que influenciou o sistema da OMC em alguns aspectos, como a preferência por soluções mutuamente negociadas, nos termos do artigo 3.7 do ESC, e a obrigação de realizar consultas, conforme o artigo 4 do ESC, antes da instauração de um painel. Embora os dois exemplos mencionados persistam no atual sistema, nota-se um "adensamento da legalidade” na OMC, oriundo da Rodada Uruguai. ${ }^{55}$ Um dos motivos que justificam essa afirmação corresponde ao aumento de normas secundárias (normas sobre normas) que regem o sistema. Exemplo disso corresponde aos artigos 9, 12, 13, 14, 17, 20 do ESC, dentre outros. ${ }^{56}$

Não obstante o “adensamento da legalidade”, a política ainda permeia o sistema de solução de controvérsias, seja na fase inicial de consultas, pela via diplomática, ou até mesmo na etapa final, quando os Estados, ainda que autorizados a retaliar outro membro da OMC, decidem se utilizam ou não o mecanismo ao seu dispor, analisando questões políticas e econômicas envolvidas.

\subsubsection{Aspectos relacionados aos países em desenvolvimento}

O sistema de solução de controvérsias da OMC prevê alguns benefícios direcionados aos países em desenvolvimento ${ }^{57}$. Somados ao aperfeiçoamento realizado em relação ao sistema vigente no GATT, tais benefícios apontam para o aumento da participação dos países em desenvolvimento no GATT, contra seus pares ou até mesmo em face de potências econômicas. ${ }^{58}$ Contudo, o aumento de participação deve-se também a outros fatores, como mudança de estratégia de alguns países em desenvolvimento. ${ }^{59}$ De qualquer modo, observa-se que tais países tiveram mais sucesso (inclusive em termos econômicos) na solução de controvérsias da OMC do que no GATT. ${ }^{61}$

\footnotetext{
${ }^{55}$ LAFER, Celso. A OMC e a regulamentação do comércio internacional: uma visão brasileira, p. 148-149.

${ }^{56}$ Idem, p. 125-126.

${ }^{57}$ Como os artigos 8.10, 12.10, 12.11, 21.2, dentre outros.

${ }^{58}$ HUDEC, Robert E. The New WTO Dispute Settlement Procedure: An Overview of the First Three Years. In: Minnesota Journal of Global Trade, v. 8, n. 1, 1999, p. 21.

59 JACKSON, John H. Dispute Settlement and the WTO: Emerging Problems, p. 341.

${ }^{60}$ Nesse contexto, afirma-se que Brasil, Índia e China utilizam o mecanismo de solução de controvérsias da OMC como instrumento estratégico para alcançar seus objetivos no sistema multilateral de comércio. Vide: LOPES, Jacqueline Spolador; ÁRABE NETO, Abrão M. Atuação dos BICS no Órgão de Solução de Controvérsias da OMC. In: THORSTENSEN, Vera; OLIVEIRA, Ivan T. M. (orgs.). Os BRICS na OMC: Políticas Comerciais Comparadas de Brasil, Rússia, Índia, China e África do Sul. Brasília: Ipea, 2012, p. 388.

${ }^{61}$ BOWN, Chad P. Developing Countries as Plaintiffs and Defendants in GATT/WTO Trade Disputes. In: The World Economy, v. 27, n. 1, 2004, p. 61.
} 
Apesar das melhorias realizadas, nota-se que a participação desses membros ainda é muito inferior ao uso realizado pelos países desenvolvidos. A disparidade aumenta ainda mais quando se compara países desenvolvidos com os de menor desenvolvimento relativo.

Embora os países em desenvolvimento tenham perfis comerciais variados, eles geralmente enfrentam três desafios na participação do sistema de solução de controvérsias na OMC: (i) reduzida expertise nas normas da OMC em relação a outros membros; (ii) recursos financeiros restritos, inclusive para contratar advogados que atuem no sistema em questão; (iii) temor de pressão política e econômica. ${ }^{62}$

Assim, observa-se que o sistema em questão necessita de alguns aprimoramentos. Cabe esclarecer que um procedimento na OMC demanda muitos recursos financeiros com a contratação de especialistas, motivo que acarreta vantagem para os países desenvolvidos. ${ }^{63}$ Desse modo, a isonomia (igualdade jurídica) entre os países na OMC torna-se paradoxal, já que os custos para a utilização do referido mecanismo são tão elevados que restringem seu uso para a maioria dos membros da Organização. ${ }^{64}$

Os países em desenvolvimento tendem a participar menos de procedimentos na OMC também por outros dois motivos. Primeiramente, o benefício caso tenham vitória é reduzido, na medida em que: (i) suas exportações tem pouco valor agregado; (ii) em geral, sua pauta de exportação não é diversificada; e (iii) a participação no comércio internacional é ínfima. Em segundo lugar, a vitória na etapa jurídica não é sinônimo de conquista na implementação da decisão, tampouco na negociação, em que forças políticas costumam prevalecer. ${ }^{65}$

Ante o exposto, conclui-se que "embora o sistema judicial da OMC seja caracterizado pelo legalismo procedimental, pela aplicação da Lei, ele permanece sendo power-oriented em sua essência." 66 Nesse contexto, observa-se que a retaliação cruzada em propriedade intelectual, conforme se verificará adiante, pode representar uma importante ferramenta em prol dos países em desenvolvimento.

\footnotetext{
62 SHAFFER, Gregory. The challenges of WTO law: strategies for developing countries adaptation. In: World Trade Review, v. 5, n. 2, 2006, p. 177.

63 SHAFFER, Gregory. O Sistema de Solução de Disputas na OMC, seus Pontos Fracos e Propostas para Aperfeiçoamento: uma Visão Econômica e de Mercado. In: BAPTISTA, Luiz Olavo; CELLI JUNIOR, Umberto; YANOVICH, Alan (orgs.). 10 anos de OMC - Uma análise do Sistema de Solução de Controvérsias e Perspectivas. São Paulo: Aduaneiras, 2007, p. 163-164.

${ }^{64}$ PRADO, Victor Luiz do. Mecanismo de Solução de Controvérsias: Fonte de Poder e de Problemas na OMC, p. 267.

${ }^{65}$ SHAFFER, Gregory. O Sistema de Solução de Disputas na OMC, seus Pontos Fracos e Propostas para Aperfeiçoamento: uma Visão Econômica e de Mercado, p. 178.

${ }^{66}$ Idem, p. 183.
} 


\subsubsection{Etapas}

O sistema de solução de controvérsias da OMC possui etapas, previstas no ESC. O artigo 3.7, transcrito abaixo, traz uma síntese das fases de uma disputa na OMC:

(...) Deverá ser sempre dada preferência à solução mutuamente aceitável para as partes em controvérsia e que esteja em conformidade com os acordos abrangidos. Na impossibilidade de uma solução mutuamente acordada, o primeiro objetivo do mecanismo de solução de controvérsias será geralmente o de conseguir a supressão das medidas de que se trata, caso se verifique que estas são incompatíveis com as disposições de qualquer dos acordos abrangidos. Não se deverá recorrer à compensação a não ser nos casos em que não seja factível a supressão imediata das medidas incompatíveis com o acordo abrangido e como solução provisória até a supressão dessas medidas. O último recurso previsto no presente Entendimento para o Membro que invoque os procedimentos de solução de controvérsias é a possibilidade de suspender, de maneira discriminatória contra o outro Membro, a aplicação de concessões ou o cumprimento de outras obrigações no âmbito dos acordos abrangidos, caso o OSC autorize a adoção de tais medidas. (grifos inexistentes no original)

A preferência por uma solução mutuamente aceitável, mencionada acima, torna a consulta a primeira das etapas que devem ser seguidas no sistema de solução de controvérsias da OMC. Além disso, essa primazia permite que o acordo seja celebrado a qualquer momento, conforme se verá adiante.

Caso a controvérsia não seja solucionada no âmbito das consultas, procede-se ao estabelecimento de um painel e, posteriormente (se as partes apelarem) à análise do Órgão de Apelação. No tocante à “supressão das medidas”, nota-se que a consonância de determinada prática com os acordos da OMC deve ser constatada por meio do relatório do painel ou do Órgão de Apelação.

Se a eliminação das medidas incompatíveis com as normas da OMC não for imediata, é possível realizar uma compensação. Tendo em vista que a compensação é voluntária e não discriminatória, a etapa seguinte, se necessária, seria a retaliação (suspensão de concessões ou outras obrigações).

A suspensão de concessões ou outras obrigações também tem uma ordem que deve ser seguida: primeiramente, deve-se tentar retaliar no mesmo setor e acordo. Caso não seja possível, deve-se buscar outro setor, mas no mesmo acordo em questão. Por fim, a última alternativa permite a retaliação em outro acordo da OMC, procedimento que é conhecido como retaliação cruzada. As etapas do sistema de solução de controvérsias na OMC estão detalhadas nos itens abaixo, com a finalidade de compreender o sistema para verificar de que forma pode ser utilizada a retaliação cruzada em propriedade intelectual. 


\subsubsection{Consultas}

A primeira etapa, como mencionado, corresponde às consultas ${ }^{67}$, as quais equivalem às vias diplomáticas na tentativa de obter um acordo entre as partes envolvidas. Muitos litígios na OMC sequer avançam esta fase. ${ }^{68}$

Caso o membro demandado não responda à consulta no prazo determinado, o membro demandante poderá solicitar o estabelecimento de um painel. ${ }^{69} \mathrm{Ou}$, se as partes envolvidas julgarem que a consulta não solucionou a disputa, também é possível estabelecer um painel. ${ }^{70}$

Mesmo após a fase de consultas, as partes podem celebrar um acordo a qualquer momento. No caso European Communities - Trade Description of Scallops ${ }^{71}$, por exemplo, as partes pediram que o relatório do painel não fosse circulado para que pudessem acordar uma solução pautada no mencionado relatório. A solução mutuamente acordada foi informada ao OSC em $1996 .^{72}$

\subsubsection{Bons ofícios, conciliação e mediação}

Cabe destacar que a disputa pode ser solucionada por meio de bons ofícios, mediação e conciliação a qualquer momento por qualquer das partes envolvidas no conflito. $^{73}$ Tais procedimentos são voluntários ${ }^{74}$, isto é, dependem de acordo entre as partes, mas também podem ser oferecidos pelo Diretor-Geral ${ }^{75}$ (ex officio).

Após a conclusão dos procedimentos de bons ofícios, conciliação ou mediação, a parte reclamante poderá solicitar o estabelecimento de um painel. Todavia, é possível que os procedimentos em questão perdurem durante os processos do painel. ${ }^{76}$

\footnotetext{
${ }^{67}$ Artigo 4 do ESC.

68 Segundo a OMC, 145 das 463 disputas estão em consultas atualmente. Disponível em: <www.wto.org/english/tratop_e/dispu_e/dispu_current_status_e.htm>. Acesso em 12/08/2013.

${ }^{69}$ Artigo 4.3 do ESC.

${ }^{70}$ Artigo 4.7 do ESC.

${ }^{71}$ Disponível em: <www.wto.org/english/tratop_e/dispu_e/cases_e/ds14_e.htm>. Acesso em 12/08/2013.

${ }^{72}$ LAFER, Celso. A OMC e a regulamentação do comércio internacional: uma visão brasileira, p. 131.

${ }^{73}$ Artigo 5 do ESC.

${ }^{74}$ Artigo 5.1 do ESC.

${ }^{75}$ Artigo 5.7 do ESC.

${ }^{76}$ Artigo 5.5 do ESC.
} 


\subsubsection{Painel}

Se as partes não firmarem um acordo na fase de consultas, procede-se ao estabelecimento de um painel ${ }^{77}$, que será responsável por prolatar um relatório ("panel report”). Caso não se recorra ao Órgão de Apelação, abaixo descrito, o relatório mencionado deve ser implementado pelas partes envolvidas na disputa.

A função do painel é auxiliar o OSC a desempenhar suas obrigações previstas tanto no ESC como nos demais acordos da OMC. Desse modo, o painel deverá analisar o assunto objetivamente, incluindo uma "avaliação objetiva dos fatos, da aplicabilidade e concordância com os acordos abrangidos pertinentes, e formular conclusões que auxiliem o OSC a fazer recomendações ou emitir decisões previstas nos acordos abrangidos.” 78

Além disso, o painel deve consultar regularmente as partes envolvidas na controvérsia, além de conceder oportunidade para tais partes encontrarem uma solução mutuamente satisfatória. As partes podem também se manifestar acerca do esboço de relatório do painel. ${ }^{79}$

Após 60 dias da distribuição do relatório do painel aos membros da OMC, o relatório deverá ser adotado em uma reunião do OSC exceto se: (i) uma das partes notificar sua decisão de apelar; ou (ii) o OSC decidir por consenso não adotar o relatório. Caso haja notificação de apelação, o relatório do painel não deverá ser considerado até a conclusão do processo de apelação. ${ }^{80}$

\subsubsection{4. Órgão de Apelação}

Na hipótese de as partes apelarem das decisões proferidas pelos painéis, cabe ao Órgão de Apelação confirmar, modificar ou revogar as conclusões e decisões jurídicas do painel. ${ }^{81}$ O Órgão de Apelação corresponde a uma espécie de "segunda instância” na disputa e trata somente de assuntos de cunho legal contidos no relatório do painel, excluindo aspectos factuais. ${ }^{82}$ Nesse sentido, afirma-se que: “O Órgão de Apelação é o

\footnotetext{
77 Artigo 4.7 do ESC.

${ }^{78}$ Artigo 11 do ESC.

${ }^{79}$ Artigos 11 e 15 do ESC.

${ }^{80}$ Artigo 16.4 do ESC.

${ }^{81}$ Artigo 17.13 do ESC.

${ }^{82}$ Artigo 17.6 do ESC. Vide também PRADO, Victor Luiz do. Mecanismo de Solução de Controvérsias: Fonte de Poder e de Problemas na OMC, p. 268.
} 
guardião da legalidade da OMC e não há espaço para levar em conta reações ou vontades políticas, sejam elas quais forem.”, 83

Cumpre esclarecer que o Órgão de Apelação é composto por sete pessoas, sendo que três delas atuam em cada caso. ${ }^{84}$ Tais pessoas não podem ter vínculos com governo e devem possuir competência reconhecida, com experiência em direito, comércio internacional e assuntos abordados pelos acordos da OMC. ${ }^{85}$ A formação do Órgão de Apelação deve representar a composição da própria OMC, motivo pelo qual seus integrantes possuem experiências e conhecimento diversificados. ${ }^{86}$

O relatório do Órgão de Apelação vincula as partes e deve ser cumprido sem restrições, exceto se o OSC decidir por consenso não adotar o referido relatório no prazo de 30 dias da sua distribuição aos membros. ${ }^{87}$

Os relatórios do Órgão de Apelação ou do painel não vinculam a interpretação dos acordos da OMC e, portanto, não acarretam consequências jurídicas aos demais membros. Todavia, as futuras decisões podem citar e utilizar precedentes da OMC na fundamentação desses relatórios. Na prática, os painéis e o Órgão de Apelação analisam os precedentes e muitas vezes seguem as interpretações anteriores. ${ }^{88}$

Caso o Órgão de Apelação ateste a incompatibilidade da medida com o acordo em questão, deverá recomendar que o membro interessado torne a medida compatível com o acordo mencionado, conforme descrito no item abaixo. Vale lembrar que tais recomendações e conclusões não poderão ampliar nem diminuir direitos e obrigações decorrentes dos acordos questionados. ${ }^{89}$

\subsection{Recomendações do painel e do Órgão de Apelação}

Como mencionado, caso haja violação às normas da OMC, o painel ou Órgão de Apelação poderá fazer uma recomendação, descrita no artigo 19.1 do ESC, que prevê:

\footnotetext{
${ }^{83}$ MURÓ, Julio A. Lacarte. Os Primeiros Anos do Órgão de Apelação e do Sistema de Solução de Disputa da OMC: uma Perspectiva Histórica. In: BAPTISTA, Luiz Olavo; CELLI JUNIOR, Umberto; YANOVICH, Alan (orgs.). 10 anos de OMC - Uma análise do Sistema de Solução de Controvérsias e Perspectivas. São Paulo: Aduaneiras, 2007, p. 40.

${ }^{84}$ Artigo 17.1 do ESC.

${ }^{85}$ Artigo 17.3 do ESC.

${ }^{86}$ BAPTISTA, Luiz Olavo. A interpretação e aplicação das regras da OMC nos primeiros anos. In: Revista de Informação Legislativa, n. 162, 2004, p. 266.

${ }^{87}$ Artigo 17.14 do ESC.

${ }^{88}$ MATSUSHITA, Mitsuo; Schoenbaum, Thomas J.; MAVROIDIS, Petros C. The World Trade Organization: Law, Practice and Policy, p. 25.

${ }^{89}$ Artigos 19.2 e 3.2 do ESC.
} 
Quando um grupo especial ou o órgão de Apelação concluir que uma medida é incompatível com um acordo abrangido, deverá recomendar que o Membro interessado torne a medida compatível com o acordo. Além de suas recomendações, o grupo especial ou o órgão de Apelação poderá sugerir a maneira pela qual o Membro interessado poderá implementar as recomendações.

Apesar de ser denominada "recomendação", a jurisprudência do GATT e da OMC demonstra que se trata de um instrumento que obriga as partes. Caso haja mais de uma forma de se adequar às regras da OMC, o painel ou o Órgão de Apelação podem sugerir qual seria a melhor opção. Cabe ressaltar que se trata de uma sugestão e, portanto, não vincula as partes. ${ }^{90}$

Após a adoção da recomendação, assegura-se o cumprimento por meio de duas medidas. A primeira corresponde a ações cogentes para pressionar o demandado, como o prazo para cumprimento e o mecanismo de monitoramento (por meio do qual são apresentados relatórios periódicos apresentando o progresso no tocante ao cumprimento da decisão). Caso a medida não se adeque às normas da OMC no prazo previsto, a segunda possibilidade remete à retaliação. A imposição de prazo para cumprimento da decisão é essencial nos casos em que países de menor poder econômico atuam em face de grandes potências ${ }^{91}$, para que não posterguem sucessivamente o cumprimento das decisões.

\subsubsection{Implementação das decisões}

Durante reunião do OSC, após 30 dias da adoção do relatório do painel ou do Órgão de Apelação, o membro interessado deverá informar ao OSC suas intenções concernentes à implementação das decisões e recomendações do Órgão. Caso não seja possível a aplicação imediata dessas recomendações e decisões, o membro interessado poderá realizá-la num prazo razoável. Na maioria dos casos, um período “razoável” não deve exceder 15 meses. ${ }^{92}$

Se não houver acordo em relação à existência de medidas designadas ao cumprimento das recomendações ou decisões ou no tocante à compatibilidade dessas medidas com o acordo abrangido, essa desavença será dirimida consoante os procedimentos de solução de controvérsias. Sempre que possível, o painel que atuou

\footnotetext{
${ }^{90}$ HUDEC, Robert E. Broadening the Scope of Remedies in the WTO Dispute Settlement, p. 355.

${ }^{91}$ Idem, p. 364-365.

${ }^{92}$ Artigo 21.3 do ESC.
} 
inicialmente na questão deverá intervir. O painel deverá entregar o relatório no prazo de 90 $\operatorname{dias}^{93} .9495$

Cabe ao OSC a supervisão da aplicação das recomendações e decisões. Qualquer membro poderá questionar a implementação das recomendações e decisões em qualquer momento posterior à sua adoção. ${ }^{96}$

\subsubsection{Medidas em caso de não implementação}

Destaca-se a possibilidade de aplicar duas medidas em caso de não implementação das decisões do painel e Órgão de Apelação. Primeiramente, deve-se tentar realizar a compensação, que é voluntária. Caso não seja possível, pode-se solicitar ao OSC a suspensão de concessões ou outras obrigações. Ambos os mecanismos estão previstos no artigo 22 do ESC e encontram-se detalhados abaixo.

\subsection{Compensação}

A compensação é uma medida temporária que pode ser utilizada se as recomendações e decisões não forem implementadas em um prazo razoável. ${ }^{97}$ Nas condições mencionadas, os membros deverão, caso seja solicitado, iniciar negociações com o intuito de estabelecer compensações mutuamente satisfatórias.

A compensação deverá ser compatível com os acordos em questão da OMC. Porém, se até 20 dias após o término do prazo razoável não houver sido acordada uma compensação, quaisquer das partes podem solicitar autorização do OSC para retaliar (suspender concessões ou outras obrigações) o membro interessado. ${ }^{98}$

Nota-se que a compensação é voluntária ${ }^{99}$, enquanto a suspensão de concessões ou outras obrigações depende de autorização do Órgão de Solução de Controvérsias. Tendo em vista que a compensação deve respeitar o princípio da nação mais

\footnotetext{
${ }^{93}$ Com possibilidade de prorrogação, desde que devidamente fundamentada.

${ }^{94}$ Artigo 21.5 do ESC.

95 A doutrina tem debatido a questão da ordem dos procedimentos previstos nos artigos 21 e 22 do ESC ("sequencing problem”). A respeito do assunto, vide: HUDEC, Robert E. Broadening the Scope of Remedies in the WTO Dispute Settlement, p. 359; MATSUSHITA, Mitsuo; SCHOENBAUM, Thomas J.; MAVROIDIS, Petros C. The World Trade Organization: Law, Practice and Policy, p. 30-32.

${ }^{96}$ Artigo 21.6 do ESC.

${ }^{97}$ Artigo 22.1 do ESC.

${ }^{98}$ Artigo 22.2 do ESC.

${ }^{99}$ Artigo 22.1 do ESC.
} 
favorecida, a ferramenta torna-se pouco utilizada. ${ }^{100}$ Além disso, a compensação pode não eliminar a medida que estiver em desacordo com as regras da OMC.

Vale lembrar também que a compensação no âmbito da OMC tem um significado diferente do que existe no Direito Internacional. Neste caso, a compensação é geralmente tratada como um mecanismo para compensar prejuízos já ocorridos. Na OMC, por outro lado, a compensação é prospectiva, pois se refere à anulação ou prejuízo causados por uma medida que não esteja em conformidade com as regras da OMC. ${ }^{101}$

\subsection{Retaliação}

Caso não haja, em um período razoável, implementação das recomendações e decisões do painel ou do Órgão de Apelação, é possível suspender, temporariamente, concessões ou outras obrigações ${ }^{102} 103$, em montante equivalente ${ }^{104}$ ao grau de anulação ou prejuízo. ${ }^{105}$ Vale lembrar que a retaliação não é preferível em relação à implementação integral de uma recomendação com o escopo de adequar determinada medida ao acordo em questão. ${ }^{106}$

A teoria legal que embasa a retaliação na OMC remete ao conceito de reciprocidade. As normas da OMC são pautadas na ideia de que cada obrigação governamental é concedida em troca das obrigações de outras partes do acordo. Desse modo, há um equilíbrio entre custo e benefício. Caso a violação não seja corrigida, a parte prejudicada tem o direito de ter o equilíbrio inicial restaurado, por meio da compensação (voluntária) ou retaliação. Contudo, a retaliação pode trazer prejuízos à economia do país retaliante e também aos seus cidadãos, conforme será demonstrado nos capítulos 3 e 4 . $^{107}$

Cumpre elucidar que a retaliação na OMC difere do que ocorre geralmente no Direito Internacional. De modo geral, quando um país viola uma obrigação internacional, ele é obrigado não apenas a cessar a medida, mas também a restituir a situação ao cenário existente antes da violação, além de ter que compensar os danos causados pela violação. Já

\footnotetext{
100 TOWNSEND, David J. Stretching the dispute settlement understanding: U.S. - Cotton's relaxed interpretation of cross-retaliation in the World Trade Organization. In: Richmond Journal of Global Law \& Business, v. 9, n. 2, 2010, p. 138.

101 VÁZQUEZ, Carlos M.; JACKSON, John H. Some Reflections of Compliance with WTO Dispute Settlement Decisions. In: Law and Policy in International Business, p. 560.

${ }^{102}$ A suspensão de concessões ou outras obrigações é sinônimo de retaliação no âmbito da OMC.

${ }^{103}$ Artigo 22.1 do ESC.

${ }^{104}$ HUDEC, Robert E. Broadening the Scope of Remedies in the WTO Dispute Settlement, p. 368.

${ }^{105}$ Artigo 22.4 do ESC.

${ }^{106}$ Artigo 22.1 do ESC.

${ }^{107}$ HUDEC, Robert E. Broadening the Scope of Remedies in the WTO Dispute Settlement, p. 366.
} 
a retaliação prevista pelo ESC é uma espécie de contramedida, cuja suspensão de direitos está limitada aos acordos da OMC, enquanto no Direito Internacional um país pode, teoricamente, suspender direitos decorrentes de outros acordos ou dos costumes internacionais, dentro de determinado limite. Ademais, a retaliação no ESC depende da autorização do OSC e limita-se ao valor dos benefícios que a parte estima perder futuramente, em decorrência de uma medida que viola as regras da OMC. No Direito Internacional, o ressarcimento envolve também as perdas já ocorridas, além dos danos previstos para o futuro. ${ }^{108}$

No tocante à suspensão de concessões ou outras obrigações na OMC, o artigo 22.3 do ESC determina uma ordem que deve ser seguida: (i) primeiramente, deve-se buscar retaliar o mesmo setor em que o painel ou Órgão de Apelação detectou uma infração ou outra anulação ou prejuízo; (ii) caso não seja possível ou eficaz a primeira hipótese, a parte deve buscar retaliar em outro setor mas no mesmo acordo questionado; (iii) apenas em último caso a parte pode retaliar em outro acordo da OMC (retaliação cruzada).

\subsection{Dificuldades dos países em desenvolvimento de aplicar a retaliação}

Apesar do caráter legal do novo sistema, problemas de cunho político e econômico permeiam o cumprimento de decisões. De fato, a retaliação permitida pela OMC pode acarretar contrarretaliação em áreas que não envolvem esta organização internacional, além de serem inúmeras vezes contra-produtivas aos países em desenvolvimento, em razão de sua dependência com relação às grandes economias. ${ }^{109}$

Na estratégia de política comercial, a capacidade para retaliar considera se o retaliante é um destino importante das exportações em uma indústria relevante (política ou economicamente) do retaliado. ${ }^{110}$ Contudo, do ponto de vista econômico, a retaliação pode ser prejudicial à economia de um país. Neste caso, a medida apenas se justifica se, no longo prazo, a retaliação ou ameaça produzir ganhos econômicos maiores do que os danos gerados. $^{111}$

\footnotetext{
${ }^{108}$ VÁZQUEZ, Carlos M.; JACKSON, John H. Some Reflections of Compliance with WTO Dispute Settlement Decisions, p. 561.

${ }^{109}$ PAUWELYN, Joost. Enforcement and Countermeasures in the WTO: Rules are Rules - Toward a More Collective Approach, p. 338.

${ }^{110}$ BOWN, Chad P. Developing Countries as Plaintiffs and Defendants in GATT/WTO Trade Disputes, p. 68.

${ }^{111}$ HUDEC, Robert E. Broadening the Scope of Remedies in the WTO Dispute Settlement, p. 365-366.
} 
A imparcialidade do mecanismo de solução de controvérsias da OMC resulta em decisões que demonstram a correta aplicação da norma jurídica, em detrimento dos interesses de grandes potências, como no caso US - Cotton. Porém, o fato de as determinações serem favoráveis ao Brasil não significa que a decisão será implementada, pois os Estados Unidos podem descumprir tais determinações.

Os pontos acima retratam uma das deficiências do sistema de solução de controvérsias da OMC. Embora as regras do ESC favoreçam o cumprimento das normas da OMC, há autores que afirmam que o sistema legal da OMC não possui um poder coercitivo (execução forçada), já que as negociações continuam após as decisões do sistema de solução de controvérsias da OMC. ${ }^{112}$

Em geral, as organizações internacionais são desprovidas de mecanismos para regular o cumprimento de suas regras e decisões e também casos em que tais ferramentas são limitadas. O Fundo Monetário Internacional (FMI), por exemplo, consegue exigir a implementação de suas normas quando concede empréstimos a determinado país, mas, quando isso não ocorre, dificilmente o FMI intervém.

Ainda que a possibilidade de retaliar aumente a eficácia do sistema de solução de controvérsias da OMC, “o principal mecanismo para forçar a execução da decisão é a retaliação e este mecanismo depende do poder que o país exerce no mercado". ${ }^{113} \mathrm{Em}$ outras palavras, a retaliação para efetivar o cumprimento de uma decisão pode prejudicar quem a aplicou, pois pode acarretar aumento de preços no mercado interno e sanções fora do âmbito da OMC.

Embora a OMC tenha se tornado mais orientada por regras ("rule-oriented"), os economistas asseveram que o cumprimento com as normas da OMC ainda depende do poder, tendo em vista que a ameaça de retaliação bilateral é uma forma utilizada nas negociações de solução de controvérsias. Assim, teorias econômicas sugerem que se o demandante deseja uma compensação ${ }^{114}$ pela recusa do demandado em cumprir as regras da OMC, ele deve ter capacidade de fazer sua própria retaliação bilateral. ${ }^{115}$

O cenário é ainda mais grave tendo em vista que a retaliação em bens pode não produzir o efeito almejado, se o país que a aplicar tiver limitações na retaliação em bens e, provavelmente, nesta hipótese o percentual dessa retaliação será insignificante para a

\footnotetext{
112 SHAFFER, Gregory. O Sistema de Solução de Disputas na OMC, seus Pontos Fracos e Propostas para Aperfeiçoamento: uma Visão Econômica e de Mercado, p. 177.

${ }^{113}$ Idem, p. 183.

${ }^{114} \mathrm{O}$ termo compensação nesta frase não se refere ao mecanismo com nome equivalente na OMC.

${ }^{115}$ BOWN, Chad P. Developing Countries as Plaintiffs and Defendants in GATT/WTO Trade Disputes, p. 60.
} 
economia de um país desenvolvido, caso ele seja o alvo da medida. Isso torna, inúmeras vezes, a retaliação em bens ineficaz, principalmente para os países em desenvolvimento. ${ }^{116}$ Para ser eficaz, a retaliação deve: (i) acarretar perda para a parte retaliada; e (ii) beneficiar o país que retaliou, caso contrário ele perderá a credibilidade. ${ }^{117}$

\subsection{Retaliação cruzada}

Neste cenário emerge a possibilidade da retaliação cruzada prevista no artigo 22.3(c) do ESC, abaixo transcrito:

Artigo 22

Compensação e Suspensão de Concessões

(...)

3. Ao considerar quais concessões ou outras obrigações serão suspensas, a parte reclamante aplicará os seguintes princípios e procedimentos:

(a) o princípio geral é o de que a parte reclamante deverá procurar primeiramente suspender concessões ou outras obrigações relativas ao(s) mesmo(s) setor(es) em que o grupo especial ou órgão de Apelação haja constatado uma infração ou outra anulação ou prejuízo;

(b) se a parte considera impraticável ou ineficaz a suspensão de concessões ou outras obrigações relativas ao(s) mesmo(s) setor(es), poderá procurar suspender concessões ou outras obrigações em outros setores abarcados pelo mesmo acordo abrangido;

(c) se a parte considera que é impraticável ou ineficaz suspender concessões ou outras obrigações relativas a outros setores abarcados pelo mesmo acordo abrangido, e que as circunstâncias são suficientemente graves, poderá procurar suspender concessões ou outras obrigações abarcadas por outro acordo abrangido;

(...)

O artigo acima torna evidente que há uma ordem a ser seguida antes de aplicar a retaliação cruzada. Além disso, há também outros requisitos que devem ser cumpridos para solicitar a retaliação cruzada, que serão analisados no capítulo 3. O presente trabalho, como já mencionado, restringir-se-á à retaliação cruzada em propriedade intelectual.

Portanto, torna-se importante entender a importância da propriedade intelectual para os países que podem sofrer os efeitos da suspensão de concessões ou outras obrigações no âmbito do TRIPS. Após a compreensão da matéria, serão apresentados os requisitos da retaliação cruzada, bem como a interpretação de tais elementos nos três precedentes da retaliação cruzada em propriedade intelectual na OMC.

116 SUBRAMANIAN, Arvind; WATAL, Fayashree. Can TRIPS serve as an enforcement device for developing countries in the WTO? In: Journal of International Economic Law, v. 3, n.3, 2000, p. 403.

${ }^{117}$ Idem, p. 405-406. 


\section{PROPRIEDADE INTELECTUAL}

Este capítulo objetiva fornecer uma base em propriedade intelectual para facilitar a compreensão da retaliação cruzada no acordo sobre o tema. Desse modo, não se almeja esgotar o estudo sobre a propriedade intelectual, tema complexo e subdividido em inúmeras vertentes.

Com esse intuito, o capítulo está dividido basicamente em considerações iniciais, aspectos econômicos da propriedade intelectual e impactos da propriedade intelectual no Direito Internacional. O último tópico apresenta detalhes focados no comércio internacional, com destaque para o TRIPS e as negociações que o precederam.

\subsection{Considerações iniciais}

A propriedade intelectual corresponde ao conjunto de direito oriundos das concepções da inteligência e do trabalho intelectual, analisados à luz de seus resultados pecuniários. No domínio das artes e ciências encontra-se a propriedade literária, científica e artística, enquanto o plano das indústrias reflete-se na propriedade industrial. Nessa esfera, são protegidos desenhos industriais, invenções, criações literárias e científicas, dentre outros. 118

O artigo 1.2 do TRIPS define o termo "propriedade intelectual” como todas as categorias objeto das Seções 1 a 7 da Parte II, quais sejam: (i) direitos do autor e direitos conexos; (ii) marcas; (iii) indicações geográficas; (iv) desenhos industriais; (v) patentes; (vi) topografias de circuitos integrados; (vii) proteção de informação confidencial.

Os direitos de propriedade intelectual podem ser analisados sob os seguintes aspectos:

Caráter patrimonial ou pecuniário, consistentes na faculdade de fruir, de modo exclusivo, todas as vantagens materiais que a obra oferecer; e o direito moral do autor, inerente à sua personalidade, que se manifesta, principalmente, no direito que lhe assiste de ser reconhecido como tal em relação à sua obra e de ligar a ela o seu nome. ${ }^{119}$

\subsection{Aspectos econômicos da propriedade intelectual}

\footnotetext{
118 GAMA CerqueIRA, João da. Tratado da Propriedade Industrial, v. 1, 2ª Ed. São Paulo: Revista dos Tribunais, 1982, p. 50-52.

${ }^{119}$ Idem, p. 51-52.
} 
Os direitos de propriedade intelectual almejam proteger o titular da imitação fraudulenta pelos seus concorrentes. ${ }^{120}$ Desse modo, é conferido um direito temporário ao titular da criação, mediante o cumprimento de certos requisitos. A implementação de um sistema de proteção aos direitos da propriedade intelectual objetiva incentivar as empresas a produzir novos conhecimentos, os quais se tornarão públicos após um período de proteção. ${ }^{121}$ A inovação é estratégica para diversas empresas, que aumentam sua rentabilidade e market share vendendo produtos de alta qualidade por um preço maior. ${ }^{122}$

Assim, os direitos de propriedade intelectual almejam estimular a inovação oferecendo a expectativa de uma recompensa financeira, a qual permite que os titulares desses direitos recuperem os investimentos realizados em pesquisa e desenvolvimento. Consequentemente, free-riders (que não realizam investimentos) são inibidos de praticar a pirataria. ${ }^{123}$ Esse objetivo geralmente é alcançado pela concessão de direitos exclusivos para a exploração dos objetos de proteção. ${ }^{124}$ Porém, o retorno financeiro nem sempre é alcançado, pois:

Uma patente não assegura de nenhum modo o sucesso comercial ou alguma vantagem no
mercado. Um número incontável de invenções patenteadas nunca alcança sucesso comercial. A
marca registrada para bens e serviços específicos não impede outros de oferecer um produto ou
serviço competitivo, usando outra marca de identificação. O copyright impede somente a
cópia, e não os trabalhos que podem ser um tanto parecidos, mas que tenham características
suficientes para serem distinguidos. O segredo de negócios não impede outros de chegar
independentemente àquele mesmo segredo. ${ }^{125}$

Cumpre esclarecer que as prerrogativas concedidas no âmbito da propriedade intelectual não devem ser confundidas com monopólio. ${ }^{126}$ Nesse sentido, afirma-se que “ $a$ propriedade intelectual cria apenas o direito de excluir outros de um produto ou processo específico. Mas, o monopólio clássico é a capacidade de excluir outros de um determinado mercado". ${ }^{127}$

\footnotetext{
${ }^{120}$ LIOTARD, Isabelle. Les droits de propriété intellectuelle, une nouvelle arme stratégique des firmes. In: Revue d'économie industrielle, v. 89, n. 89, 1999, p. 70.

${ }^{121}$ DEFFAINS, Bruno. Progrès scientifique et analyse économique des droits de propriété intellectuelle. In : Revue d'économie industrielle, v. 79, n. 79, 1997, p. 95.

${ }^{122}$ GREENHALGH, Christine; ROGERS, Mark. Innovation, intellectual property, and economic growth. Princeton: Princeton University Press, 2010, p. 150.

${ }^{123}$ REICHMAN, Jerome; LANGE, David. Bargaining around the TRIPS agreement: the case for ongoing public-private initiatives to facilitate worldwide Intellectual Property transactions. In: Duke Journal of Comparative \& International Law, v. 9, n. 1, 1998, p. 20.

${ }^{124}$ CORREA, Carlos M. Trade related aspects of intellectual property rights: a commentary on the TRIPS agreement. Oxford: Oxford University Press, 2007, p. 95.

${ }^{125}$ SHERWOOD, Robert M. Propriedade Intelectual e Desenvolvimento Econômico, tradução de Heloísa de Arruda Villela. São Paulo: Editora da Universidade de São Paulo, 1992, p. 60.

${ }^{126}$ BASSO, Maristela. Importação paralela: efeitos no comércio internacional e nos direitos de propriedade intelectual. Tese apresentada para o Concurso de Professor Titular da Faculdade de Direito da USP, Departamento de Direito Internacional e Comparado. São Paulo, 2009, p. 225.

${ }^{127}$ SHERWOOD, Robert M. Propriedade Intelectual e Desenvolvimento Econômico, p. 60.
} 
Independente dessa discussão econômica, que se distancia do objeto desta dissertação, destaca-se que há diversos debates relacionados aos impactos da proteção dos direitos de propriedade intelectual sobre acesso a medicamentos e a bens culturais. Tais questões serão abordadas nos capítulos seguintes sobre retaliação cruzada em propriedade intelectual.

\subsection{Impactos da propriedade intelectual sobre o Direito Internacional}

Cabe destacar a vinculação entre os direitos de propriedade intelectual e o Direito Internacional. ${ }^{128}$ As primeiras normas internacionais relativas aos direitos de propriedade intelectual surgiram durante a Revolução Industrial, frente à necessidade de uniformizar as normas de direito privado entre os Estados. ${ }^{129}$ Nesse contexto, cumpre esclarecer que a Revolução Industrial e a invenção da imprensa aumentaram a importância de proteger os direitos de propriedade intelectual, pois possibilitaram a reprodução de obras e mercadorias em ampla escala. ${ }^{130}$

Com a intensificação do comércio internacional após a Segunda Guerra Mundial e da realização de investimentos no exterior, a proteção dos direitos de propriedade intelectual tornou-se ainda mais importante. As demandas pela criação de regras no âmbito internacional sobre propriedade intelectual ensejaram a elaboração de diversos tratados, como a Convenção de Paris para a Proteção da Propriedade Industrial ${ }^{131}$ e a Convenção de Berna para a Proteção das Obras Literárias e Artísticas ${ }^{132}$. Essas convenções eram administradas pelo Bureaux Internationaux Réunis pour la Protection de la Propriété Intellectuelle (BIRPI).

Após o aumento da importância da propriedade intelectual na economia e o crescimento de convenções sobre o tema, o BIRPI foi transformado em 1967 na Organização Mundial da Propriedade Intelectual (OMPI), uma agência especializada das

\footnotetext{
${ }^{128}$ Vide BASSO, Maristela. A proteção da propriedade intelectual e o direito internacional atual. In: Revista de informação legislativa, v. 41, n. 162, 2004, p. 287-309.

129 BASSO, Maristela. O direito internacional da propriedade intelectual. Porto Alegre: Livraria do Advogado, 2000, p. 64.

130 SILVEIRA, Newton. Propriedade intelectual: propriedade industrial, direito de autor, software, cultivares, nome empresarial. $4^{\text {a }}$ ed., Barueri: Manole, 2011, p. 12-13.

131 A Convenção de Paris foi assinada em 1883. Com 174 partes contratantes, referida Convenção é administrada atualmente pela OMPI. Mais informações disponíveis em: $<$ www.wipo.int/treaties/en/ip/paris/>. Acesso em 07/07/2013.

132 A Convenção de Berna foi assinada em 1886. Com 166 partes contratantes, referida Convenção é administrada atualmente pela OMPI. Mais informações disponíveis em: $<$ www.wipo.int/treaties/en/ip/berne/>. Acesso em 07/07/2013.
} 
Nações Unidas. ${ }^{133}$ Com 186 Estados-membros, a OMPI tem como função promover a inovação para o desenvolvimento econômico, social e cultural dos países, por meio de um sistema internacional equilibrado de propriedade intelectual. ${ }^{134}$ Posteriormente, a propriedade intelectual foi inserida no âmbito da OMC, conforme se verá nos itens seguintes.

\subsubsection{A propriedade intelectual no comércio internacional}

A relação entre propriedade intelectual e comércio pauta-se principalmente em dois aspectos. Primeiro, a pirataria, a contrafação e outras violações dos direitos de propriedade intelectual correspondem a barreiras ao comércio, reduzindo o acesso a mercados. Ressalte-se que tal ideia não representa, necessariamente, o ponto de vista dos países em desenvolvimento. Em segundo lugar, observa-se a questão da transferência de tecnologia e seus consequentes investimentos, salientando a necessidade de regular a propriedade intelectual voltada para o comércio. ${ }^{135}$ Nesse sentido:

A questão da propriedade intelectual afeta a área do comércio internacional de várias maneiras.
Uma delas é que os produtores e exportadores de bens de maior conteúdo tecnológico desejam
garantir que os altos custos que incorreram com pesquisa e desenvolvimento fiquem protegidos
nos países importadores. Outra maneira é porque os investidores desejam produzir localmente,
ou conceder licenças de produção a países que tenham como garantir a proteção da tecnologia
transferida. Finalmente, produtores e exportadores estão cada vez mais preocupados com a
questão da pirataria e contrafação em países que não dão proteção à propriedade intelectual. ${ }^{136}$

Observa-se, portanto, que os benefícios da propriedade intelectual estão relacionados ao desenvolvimento tecnológico e aos investimentos estrangeiros (na medida em que promovem a inovação e a criatividade), fomentando o comércio mundial. ${ }^{137}$ Como geralmente os países desenvolvidos possuem mais recursos financeiros e tecnologia para realizar investimentos, inclusive em outros Estados, torna-se evidente a preocupação desses Estados com o tema.

A propriedade intelectual envolve transferência de divisas dos países desenvolvidos para países em desenvolvimento. Neste caso, essas divisas encontram-se sob a forma de segredo industrial, marcas, indicações geográficas, direitos autorais, desenhos

${ }_{133}$ LOWENFELD, Andreas F. International Economic Law, $2^{\mathrm{a}}$ ed. Nova Iorque: Oxford University Press, 2008, p. 338-339.

${ }^{134}$ Disponível em < www.wipo.int>. Acesso em 03/07/2013.

135 MATSUSHITA, M.; SCHOENBAUM; Thomas J.; MAVROIDIS, Petros C. The World Trade Organization: Law, Practice, and Policy, p. 397.

${ }^{136}$ THORSTENSEN, Vera. OMC: Organização Mundial do Comércio: as regras do comércio internacional e a nova rodada de negociações multilaterais, p. 201.

${ }^{137}$ BASSO, Maristela. O Regime Internacional de Proteção da Propriedade Intelectual da OMC/Trips, p. 116. 
industriais, dentre outros. Assim, observa-se que a propriedade intelectual é intangível, facilmente reproduzida e apropriada, pois o custo marginal de reprodução é próximo de zero. $^{138}$

Portanto, a proteção dos direitos de propriedade intelectual é fundamental para a inovação, que demanda vultosos investimentos. Nesse contexto, salienta-se que fortalecer os direitos de propriedade intelectual nos países em desenvolvimento reduz o risco de investidores estrangeiros e cientistas, permitindo que se sintam mais confortáveis em compartilhar suas tecnologias e recursos com tais Estados. ${ }^{139}$

\subsubsection{Propriedade intelectual no GATT 47}

O aumento da relevância da propriedade intelectual como uma ferramenta que acumula divisas em um país está relacionado ao cenário pós-Segunda Guerra Mundial. O crescimento das telecomunicações e do setor militar apontava para o fortalecimento do papel da ciência e da tecnologia. Apesar disso, tais mudanças não estavam refletidas no GATT 47, o qual continha poucas referências ao tema. ${ }^{140}$

O elevado valor dos produtos com tecnologia de ponta, o crescimento da contrafação envolvendo diversos produtos ${ }^{141}$ e a necessidade de completar as deficiências do sistema de proteção da propriedade intelectual da OMPI correspondem às principais razões que levaram à tentativa de inserir o tema da propriedade intelectual no sistema GATT 47. ${ }^{142}$ Cumpre elucidar que as negociações no GATT 47 e na OMC englobam apenas os aspectos da propriedade intelectual relacionados ao comércio, enquanto a OMPI abrange a propriedade intelectual como um todo.

Nesse cenário, torna-se fundamental compreender o histórico do TRIPS, incluindo o papel dos atores relevantes para a conclusão deste acordo, em especial do setor privado. É importante compreender o histórico por trás do TRIPS, porque este é o acordo utilizado na retaliação cruzada em propriedade intelectual no âmbito do OSC. Como se

\footnotetext{
138 ABBOTT, Frederick M. Protecting First World Assets in the Third World: Intellectual Property Negotiations in the GATT Multilateral Framework. In: Vanderbilt Journal of Transnational Law, v. 22, n. 4, 1989, p. 697.

${ }^{139}$ KHOURY, Amir. Intellectual property, trade, and development: a view from the United States. In: GERVAIS, Daniel J. (ed.). Intellectual property, trade and development: strategies to optimize economic development in a TRIPS-plus era. Oxford: Oxford University Press, 2007, p. 341.

${ }^{140}$ ABBOTT, Frederick M. Protecting First World Assets in the Third World: Intellectual Property Negotiations in the GATT Multilateral Framework, p. 695-696.

${ }^{141}$ LOWENFELD, Andreas F. International Economic Law, p. 108.

${ }^{142}$ BASSO, Maristela. O Direito Internacional da Propriedade Intelectual, p. 159.
} 
observará nos capítulos 3 e 4, os atores que esboçaram o acordo em questão são os mais atingidos em eventual retaliação cruzada.

\subsubsection{Negociações relativas ao TRIPS}

Para compreender o histórico do TRIPS, é importante analisar o cenário político e econômico dos Estados Unidos (onde o TRIPS foi esboçado) na década de 1970. No período em questão, havia um declínio econômico naquele país, refletido nos déficits comerciais. O crescimento do Japão e do leste asiático ensejou debates na política norteamericana sobre alternativas para aprimorar a competitividade. Ademais, a crescente importância de setores de alta tecnologia na economia global aumentou o interesse dos formuladores de políticas em propriedade intelectual, que poderia ser utilizada como uma ferramenta para majorar a competitividade. ${ }^{143}$

No plano internacional, observa-se que a inovação e os componentes tecnológicos tornaram-se um fator essencial para a competitividade. Paralelamente, constatava-se o aumento da relevância do comércio internacional para o PIB dos países e a intensificação da interdependência entre os Estados. ${ }^{144}$

Ressalte-se que desde a negociação do acordo GATT, em 1947, a importância da propriedade intelectual já era reconhecida, pois tal tema permeia alguns dispositivos do GATT, ainda que de forma tímida. ${ }^{145}$ Entretanto, a repercussão da propriedade intelectual sobre o comércio ficou evidente apenas após a década de 70, quando se percebeu a relação entre propriedade intelectual e o desenvolvimento tecnológico. ${ }^{146}$

Desse modo, indústrias que dependiam de direitos de propriedade intelectual ganharam influência na política estadunidense, em detrimento de indústrias tradicionais. O crescente lucro das indústrias de capital intensivo contrapunha-se ao déficit comercial dos Estados Unidos. As indústrias farmacêuticas, de entretenimento e de software eram notáveis exportadores, que ostentavam balanças comerciais positivas. Nesse contexto,

\footnotetext{
143 SELL, Susan K., Industry Strategies for Intellectual Property and Trade: The Quest for TRIPS, and PostTRIPS Strategies. In: Cardozo Journal of International and Comparative Law, v. 10, n. 1, 2002, p. 81.

144 ABBOTT, Frederick M. Protecting First World Assets in the Third World: Intellectual Property Negotiations in the GATT Multilateral Framework, p. 696-697.

${ }^{145}$ Como os artigos IX(6), XII(3)iii, XVIII(10) e XX(d).

${ }^{146}$ BASSO, Maristela. O Direito Internacional da Propriedade Intelectual, p. 160.
} 
emergia a ideia de livre comércio, desde que justo. Portanto, era necessário reduzir as distorções oriundas das práticas ilícitas de outros países. ${ }^{147}$

Assim, o governo dos Estados Unidos estimulou o investimento no exterior e destacou o United States Trade Representative (USTR) como o órgão responsável para receber queixas das indústrias e para coordenar esforços no governo norte-americano para desenvolver as respostas a tais demandas. A partir de 1974, a competência para administrar os procedimentos no âmbito da Seção (“Section”) 301 passou para o USTR. ${ }^{148}$

A Seção 301 (que está em vigor atualmente ${ }^{149}$ ) do U.S. Trade Act permite que o presidente dos Estados Unidos negue benefícios ou imponha direitos sobre produtos ou serviços de países que restringirem o comércio de modo injustificado. ${ }^{150}$ Desse modo, o USTR se destacou nessa época por tratar de questões relativas a investimentos e por usar medidas comerciais para combater restrições a investimentos no exterior. Emendas à Seção 301 marcaram a participação do setor privado na política de comércio exterior e, consequentemente, estabeleceram uma relação de cooperação entre os setores público e privado. Assim, os Estados Unidos começaram a usar o acesso a mercados como barganha para obter liberalização de investimentos e aumento da proteção de direitos de propriedade intelectual no exterior. ${ }^{151}$

Nesse período, a maioria dos investimentos em novas tecnologias estava concentrada nos países membros da Organização para a Cooperação e Desenvolvimento Econômico (OCDE). Desse modo, o aumento da proteção aos direitos de propriedade intelectual estava relacionado à tentativa de aumentar o fluxo de capitais para os países desenvolvidos. $^{152}$

Nesse contexto, diversas indústrias relevantes pressionavam para a inclusão do tema da propriedade intelectual relacionada ao comércio durante as negociações da Rodada Tóquio. Além disso, muitas empresas norte-americanas engajaram-se nas consultas

\footnotetext{
${ }^{147}$ SELL, Susan K., Industry Strategies for Intellectual Property and Trade: The Quest for TRIPS, and PostTRIPS Strategies, p. 81.

${ }^{148}$ Idem, p. 82.

${ }^{149}$ Vide: <www.ustr.gov/trade-topics/intellectual-property>. Acesso em 12/08/2013.

${ }^{150}$ Destaca-se o uso da Seção 301 contra o Brasil e a Índia no final de década de 1980. Nesse sentido, vide DRAHOS, Peter. Negotiating Intellectual Property Rights: Between Coercion and Dialogue. In: International Intellectual Property Law \& Policy, v. 7, 2002, p. 82-1-82-17.

${ }^{151}$ SELL, Susan K., Industry Strategies for Intellectual Property and Trade: The Quest for TRIPS, and PostTRIPS Strategies, p. 82.

152 ABBOTT, Frederick M. The TRIPS-Legality of Measures Taken to Address Public Health Crises: Responding to USTR-State-Industry Positions That Undermine the WTO. In: KENNEDY, Daniel L.M.; SOUTHWICK, James D. (ed.). The political economy of international trade law: essays in honor of Robert E. Hudec. Cambridge: Cambridge University Press, 2002, p. 313.
} 
bilaterais (realizadas pelo USTR) com parceiros comerciais para tratar de supostas violações aos direitos de propriedade intelectual. ${ }^{153}$

A pretensão de incluir o tema na Rodada Tóquio estava relacionada à tentativa de aprimorar os tratados internacionais que vigoravam na época. No tocante à Convenção de Paris para a Proteção da Propriedade Industrial, destacam-se os seguintes aspectos, na visão do setor privado dos Estados Unidos naquela época: (i) as questões de tecnologias não eram devidamente tratadas; (ii) não havia um período mínimo de proteção da patente; (iii) não havia expressamente uma compensação financeira para licenças compulsórias; (iv) a convenção era muito permissiva para a concessão de licenças compulsórias; (v) faltava um sistema de solução de disputas eficaz. A Convenção de Berna para a Proteção das Obras Literárias e Artísticas também era criticada pela ausência de um sistema eficaz de solução de controvérsias. ${ }^{154}$

Devido principalmente à preocupação do governo relacionada à competitividade comercial e ao poder econômico baseado nas indústrias de alta tecnologia, o setor privado teve acesso aos mais elevados níveis da formulação de política nos Estados Unidos. ${ }^{155}$ O lobby do setor privado em prol do aumento da proteção dos direitos de propriedade intelectual intensificou-se em 1983 e 1984, destacando-se a atuação dos setores farmacêutico e de entretenimento. Do mesmo modo, a cooperação entre indústrias editorial e de entretenimento fortaleceu-se para aumentar a proteção aos direitos de propriedade intelectual na legislação nacional. ${ }^{156}$

Em seguida, a mencionada cooperação culminou na criação, em 1984, da International Intellectual Property Alliance (IIPA), composta por associações comerciais que representam indústrias dos Estados Unidos na área de direitos autorais. A IIPA atua no aprimoramento da proteção internacional e aplicação dos direitos autorais, com o intuito de abrir mercados dominados por pirataria e outras barreiras comerciais. ${ }^{157}$ Referida entidade foi a principal representante das indústrias de direitos autorais que assessorou o governo dos Estados Unidos nas negociações do TRIPS. ${ }^{158}$

\footnotetext{
153 SELL, Susan K., Industry Strategies for Intellectual Property and Trade: The Quest for TRIPS, and PostTRIPS Strategies, p. 83.

154 ABBOTT, Frederick M. Protecting First World Assets in the Third World: Intellectual Property Negotiations in the GATT Multilateral Framework, p. 702-705.

${ }^{155}$ SELL, Susan K., Industry Strategies for Intellectual Property and Trade: The Quest for TRIPS, and PostTRIPS Strategies, p. 84.

${ }^{156}$ Idem, p. 85.

${ }^{157}$ Atualmente representa mais de 3.200 empresas dos Estados Unidos, produtoras e distribuídas de materiais protegidos por direitos autorais, como software (incluindo jogos), filmes, programas de televisão, músicas, CDs, DVDs e livros. Mais informações disponíveis em: <www.iipa.com>. Acesso em 21/06/2013.

${ }^{158}$ Disponível em <www.iipa.com/aboutiipa.html>. Acesso em 21/06/2013.
} 
O lobby das indústrias interessadas na proteção dos direitos de propriedade intelectual (principalmente os setores farmacêutico, editorial e de entretenimento) resultou na emenda do Trade and Tariff Act de 1984. Pela primeira vez foi incluído um dispositivo consoante o qual falhas na adequada proteção aos mencionados direitos poderiam ser acionadas no âmbito da Seção 301, a qual permite que o setor privado apresente pedidos de investigação de ações de governos estrangeiros.

A emenda em questão incluiu a proteção aos direitos de propriedade intelectual como um critério para tornar um país em desenvolvimento elegível às concessões comerciais não recíprocas no âmbito do Sistema Geral de Preferências (SGP). Em 1984, a Comunidade Europeia promulgou uma regra similar à Seção $301^{159}$. Já o Japão, embora não tenha utilizado instrumentos bilaterais relacionados à propriedade intelectual, foi pressionado pelos Estados Unidos a cancelar sua proposta de proteção a software. ${ }^{160}$

Após a conquista na esfera legislativa dos Estados Unidos, a pressão do setor privado voltou-se para o cumprimento do novo dispositivo. ${ }^{161}$ Posteriormente, em 1988 foram fortalecidos os dispositivos sobre a proteção aos direitos de propriedade intelectual no Trade Act dos Estados Unidos. ${ }^{162}$ Nesse mesmo ano, a pedido da Associação dos Fabricantes de Medicamentos (Pharmaceutical Manufacturers Association), o USTR impôs aproximadamente 40 milhões de dólares em tarifas sobre determinadas importações brasileiras como consequência da contínua recusa do Brasil de estender a proteção patentária a medicamentos. O Brasil, por sua vez, levou a questão ao GATT. ${ }^{163}$

No âmbito multilateral, em 1984, o USTR solicitou ao setor privado subsídios relacionados à inclusão da propriedade intelectual na agenda da próxima rodada do GATT. Concomitantemente, havia uma resistência dos países em desenvolvimento, destacando-se a atuação do Brasil e da Índia. ${ }^{164}$ Nesse contexto, um grupo de empresas multinacionais que incluía setores diversos (como químico, eletrônico e farmacêutico) formou um grupo denominado Intellectual Property Committee (IPC) que sugeria os seguintes aspectos para um acordo internacional sobre propriedade intelectual: (i) um código com padrões

\footnotetext{
${ }^{159}$ Regulamento n²64/84.

${ }^{160}$ DRAHOS, Peter. Developing Countries and International Intellectual Property Standard-Setting. In: The Journal of World Intellectual Property, v. 5, n. 5, 2002, p. 773.

${ }^{161}$ SELL, Susan K., Industry Strategies for Intellectual Property and Trade: The Quest for TRIPS, and PostTRIPS Strategies, p. 86-87.

162 ABBOTT, Frederick M. Protecting First World Assets in the Third World: Intellectual Property Negotiations in the GATT Multilateral Framework, p. 708.

163 Idem, p. 709-710.

${ }^{164}$ DRAHOS, Peter. Developing Countries and International Intellectual Property Standard-Setting. In: The Journal of World Intellectual Property, v. 5, n. 5, 2002, p. 773.
} 
mínimos de proteção aos direitos autorais, de patentes, marcas, e indicações geográficas; (ii) aplicação das regras (“enforcement”); (iii) um mecanismo de solução de controvérsias. $^{165}$

Em 1986, o International Trade Commission (ITC) compilou 736 questionários de empresas sediadas nos Estados Unidos, incluindo as 500 “Fortune companies", sobre os efeitos das deficiências de terceiros países relativas à proteção da propriedade intelectual. Com base nesses dados, foi estimada uma perda US\$ 43 a US\$ 61 bilhões de dólares das indústrias dos Estados Unidos. Um considerável número das empresas envolvidas afirmou que as perdas tinham crescido principalmente a partir do início da década de 1970. Acerca dessa informação, o ITC atribuiu a situação a alguns fatores, como: crescimento do comércio internacional; aumento de produção dos países em desenvolvimento; investimentos realizados para produzir em outros países, que nem sempre tinham nível adequado de proteção aos direitos de propriedade intelectual. As indústrias mais afetadas pertenciam aos setores químico, farmacêutico, de software e de entretenimento (áudio e vídeo). ${ }^{166}$

No plano doméstico, o IPC contatou a Câmara de Comércio dos Estados Unidos (U.S. Chamber of Commerce) e diversas associações industriais com o intuito de persuadi-los acerca da relação entre propriedade intelectual e comércio. A iniciativa foi bem-sucedida e, em 1986, o Grupo de Trabalho Conjunto sobre temas de propriedade intelectual e GATT da Câmara de Comércio Internacional (CCI) recomendou a inclusão da propriedade intelectual na nova rodada do GATT. ${ }^{167}$ A possibilidade de aplicar sanções, por meio do sistema de solução de controvérsias, em decorrência do descumprimento das regras do GATT (e posteriormente da OMC), tornou-se um atrativo para buscar a inserção da propriedade intelectual na OMC. ${ }^{168}$

O IPC sinalizou um consenso da indústria em relação ao tema em questão e obteve apoio de seus pares na Europa e Japão, os quais apresentaram o novo posicionamento aos seus respectivos governos com o intuito de incluir o assunto na Rodada Uruguai. Desse modo, Estados Unidos, Japão e Europa uniram-se para incluir um

\footnotetext{
${ }^{165}$ SELL, Susan K., Industry Strategies for Intellectual Property and Trade: The Quest for TRIPS, and PostTRIPS Strategies, p. 91.

${ }^{166}$ ABBOTT, Frederick M. Protecting First World Assets in the Third World: Intellectual Property Negotiations in the GATT Multilateral Framework, p. 700-702.

${ }^{167}$ SELL, Susan K., Industry Strategies for Intellectual Property and Trade: The Quest for TRIPS, and PostTRIPS Strategies, p. 91-92.

${ }^{168}$ Nesse sentido, vide: JACKSON, John H. Dispute Settlement and the WTO: Emerging Problems, p. 338.
} 
acordo sobre propriedade intelectual no GATT, apresentando uma minuta em $1988 .{ }^{169} \mathrm{O}$ documento apresentava padrões mínimos de proteção aos direitos de propriedade intelectual, além de dispor sobre aplicação (“enforcement”) e solução de controvérsias. ${ }^{170}$

A coordenação do setor privado com os governos era essencial para assegurar o posicionamento das empresas no GATT (e posteriormente na OMC), já que apenas os Estados participam dessas negociações. É interessante notar que os países em desenvolvimento costumam ter menor coordenação entre os poderes público e privado. Além disso, ao contrário do que fazem Estados Unidos e União Europeia, diversos países em desenvolvimento tendem a atribuir menor importância a assuntos comerciais no âmbito da hierarquia governamental. ${ }^{171}$ Apesar disso, os países em desenvolvimento, incluindo Brasil e Índia, apresentavam oposição à inclusão da propriedade intelectual no GATT. ${ }^{172}$

Entre 1986 e abril de 1989, os temas de propriedade intelectual ficaram estagnados nas negociações comerciais. Um grupo de países em desenvolvimento (“Group of Ten"), liderado por Brasil e Índia, protestou veementemente contra a inclusão da propriedade intelectual no GATT. Eles alegavam que o GATT não era o foro adequado para a negociação de padrões substanciais de propriedade intelectual. ${ }^{173}$

Os países em desenvolvimento, temendo elevação de preços decorrentes do aumento da proteção aos direitos de propriedade intelectual, usavam seus votos para bloquear propostas de reformas na OMPI. Por conseguinte, os países desenvolvidos ampliaram esforços para inserir o tema na esfera comercial e, em troca, concederiam acesso a mercados em outros setores por meio do GATT. Apesar desse impasse, o IPC continuou atuando no âmbito multilateral, por meio de coalizões empresariais. ${ }^{174}$

É interessante observar que a coordenação dos atores internos dos países em desenvolvimento estava aquém do que ocorria nos Estados Unidos e na União Europeia. Apesar do talento dos negociadores que representavam os governos dos Estados em

\footnotetext{
${ }^{169}$ ABBOTT, Frederick M. Protecting First World Assets in the Third World: Intellectual Property Negotiations in the GATT Multilateral Framework, p. 716.

${ }^{170}$ SELL, Susan K., Industry Strategies for Intellectual Property and Trade: The Quest for TRIPS, and PostTRIPS Strategies, p. 92-93.

${ }^{171}$ SHAFFER, Gregory. The challenges of WTO law: strategies for developing countries adaptation, p. 179.

${ }^{172}$ ABBOTT, Frederick M. Protecting First World Assets in the Third World: Intellectual Property Negotiations in the GATT Multilateral Framework, p. 713.

${ }^{173}$ Idem, p. 718.

${ }^{174}$ SELL, Susan K., Industry Strategies for Intellectual Property and Trade: The Quest for TRIPS, and PostTRIPS Strategies, p. 94.
} 
desenvolvimento, havia um desequilíbrio na formulação de políticas em comparação com os países desenvolvidos. ${ }^{175}$

Parte do posicionamento dos países em desenvolvimento devia-se à questão do acesso a medicamentos, na medida em que patentes farmacêuticas poderiam privar os cidadãos de adquirirem medicamentos por um preço acessível. Ademais, alguns países em desenvolvimento temiam sofrer represálias comerciais, pois certas empresas realizavam contrafação. Apesar disso, todos os países ganhariam acesso a mercados, por meio de tarifas reduzidas no GATT. ${ }^{176}$

Outro aspecto relativo à resistência dos países em desenvolvimento às ações mencionadas deve-se ao fato de que as normas propostas relativas ao reconhecimento dos direitos de propriedade intelectual afetam o deslocamento de divisas, que deixam tais Estados em direção aos países industrializados. ${ }^{177}$ Por outro lado, é importante esclarecer que a proteção aos direitos de propriedade intelectual contribui para atrair investimentos estrangeiros e para estimular a inovação, beneficiando os países em desenvolvimento.

Em 1987, os Estados Unidos apresentaram uma proposta inicial de um acordo sobre propriedade intelectual ao Grupo de Trabalho do TRIPS. Tal proposta previa a adoção obrigatória de padrões mínimos de proteção aos direitos de propriedade intelectual, dispositivos sobre medidas aduaneiras e expedita solução de controvérsias. Em seguida, a Comunidade Europeia apresentou proposta semelhante ao de Trabalho do TRIPS. ${ }^{178}$

Enquanto as negociações sobre o tema estavam estagnadas no GATT, os Estados Unidos, pressionados pelo seu setor privado, fortaleceram suas ações unilaterais em propriedade intelectual em 1988. Alguns resultados das ações bilaterais foram apresentados em 1989: acordos sobre direitos autorais com Taiwan e Indonésia, adoção de lei sobre patentes na Arábia Saudita e a inclusão de software na lei de direitos autorais da Colômbia. Tais acordos bilaterais mitigavam paulatinamente a resistência dos países em desenvolvimento ao TRIPS. ${ }^{179}$

As alterações da Seção 301 de 1988 preocuparam diversos membros do GATT, os quais convocaram uma sessão especial no âmbito do GATT para demandar uma mudança de postura dos Estados Unidos. O país norte-americano, por sua vez, mencionou

\footnotetext{
175 ABBOTT, Frederick M. The TRIPS-Legality of Measures Taken to Address Public Health Crises: Responding to USTR-State-Industry Positions That Undermine the WTO, p. 314.

${ }^{176}$ LOWENFELD, Andreas F. International Economic Law, p. 108-109.

177 ABBOTT, Frederick M. Protecting First World Assets in the Third World: Intellectual Property Negotiations in the GATT Multilateral Framework, p. 691.

${ }^{178}$ Idem, p. 715-716.

${ }^{179}$ DRAHOS, Peter. Developing Countries and International Intellectual Property Standard-Setting, p. 774.
} 
que os procedimentos de solução de controvérsias do GATT eram muito lentos e frágeis e, portanto, não ofereciam uma proteção adequada aos interesses estadunidenses. Assim, acordaram a implementação de um sistema de solução de controvérsias mais eficaz e, em troca, os Estados Unidos firmariam o compromisso de submeter as queixas, embasadas com regras da OMC, referentes à Seção 301, ao novo sistema de solução de controvérsias. $^{180}$

Em abril de 1989, a resistência dos países em desenvolvimento relativa à inclusão da propriedade intelectual no GATT foi superada. Vale mencionar que as posições antagônicas dos países se aproximaram na medida em que os países em desenvolvimento abriram suas economias, priorizando novos investimentos que incorporassem tecnologia e que acarretassem inovação. ${ }^{181}$

Nesta etapa, as negociações intensificaram-se e diversos países em desenvolvimento engajaram-se no processo. No fim de 1989, os negociadores acordaram que os países em desenvolvimento poderiam implementar o TRIPS em um prazo maior que os países desenvolvidos. Assim, as negociações do TRIPS deslocaram-se dos debates entre países desenvolvidos e em desenvolvimento para dispositivos pontuais discutidos entre a Europa, Japão e Estados Unidos. Em alguns aspectos, houve contribuições dos países em desenvolvimento. Exemplo disso remete às exceções e limitações ao direito de patente, que obteve apoio da Europa, contrariando o posicionamento de indústrias de biotecnologia. $^{182}$

Em 1990, devido a impasses relacionados aos subsídios agrícolas, as negociações da Rodada Uruguai foram paralisadas, incluindo o TRIPS. Nesse contexto, foi elaborado o "Dunkel Draft" "183, contendo os resultados das negociações em cada setor. Após diversas críticas, as negociações finalmente obtiveram um consenso acerca do “Dunkel Draft” e a Rodada Uruguai foi concluída em abril de 1994. De acordo com uma entrevista, o IPC obteve sucesso em 95\% dos seus pleitos no TRIPS, com exceção do período de transição para países em desenvolvimento. ${ }^{184}$

\footnotetext{
${ }^{180}$ HUDEC, Robert E. Broadening the Scope of Remedies in the WTO Dispute Settlement, p. 350.

181 THORSTENSEN, Vera. OMC: Organização Mundial do Comércio: as regras do comércio internacional e a nova rodada de negociações multilaterais, p. 202.

${ }^{182}$ SELL, Susan K., Industry Strategies for Intellectual Property and Trade: The Quest for TRIPS, and PostTRIPS Strategies, p. 94-96.

${ }^{183}$ Para obter mais informações sobre o "Dunkel Draft" vide: BASSO, Maristela. O direito internacional da propriedade intelectual, p. 165-166.

${ }^{184}$ SELL, Susan K., Industry Strategies for Intellectual Property and Trade: The Quest for TRIPS, and PostTRIPS Strategies, p. 96-97.
} 
É interessante notar que a tentativa de conter ações unilaterais dos países também favoreceu a criação do TRIPS. Porém, ao mesmo tempo em que os Estados Unidos se comprometeram com as regras da OMC, o USTR anunciou ao Congresso que o ESC não teria efeito sobre a Seção 301. Nota-se uma postura contraditória do USTR, tendo em vista que um aspecto importante do ESC era conter o unilateralismo da Seção 301. Contudo, os negociadores de ambos os lados sabiam que os Estados Unidos não abandonariam totalmente sua política representada pela Seção 301 e que o país se obrigou cumprir as regras da OMC, incluindo o ESC. ${ }^{185}$

Embora a Seção 301 esteja em vigor, o estabelecimento da OMC reduziu substancialmente a justificativa para usar sanções unilaterais. Além disso, o uso de retaliações com base na Seção 301 pode sujeitar os Estados Unidos a serem questionados no OSC. ${ }^{186}$

Mesmo respeitando os ditames do TRIPS, os Estados ainda possuem o "policy space”, que é utilizado tanto para fortalecer a proteção dos direitos de propriedade intelectual (como pode ser observado nos recentes acordos regionais) quanto para a flexibilização de alguns conceitos do TRIPS, em prol da saúde pública, por exemplo.

\subsubsection{TRIPS}

Criado na Rodada Uruguai, o TRIPS estabeleceu padrões mínimos referentes à propriedade intelectual na OMC. Referido acordo dispões sobre os direitos relativos a: (i) direitos autorais e direitos conexos; (ii) marcas; (iii) indicações geográficas; (iv) desenhos industriais; (v) patentes; (vi) topografias de circuitos integrados; (vii) proteção de informação confidencial; (viii) controle de práticas de concorrência desleal em contratos de licenças. Dos itens mencionados, os sete primeiros estão sujeitos à retaliação cruzada em propriedade intelectual, bem como as partes III e IV do TRIPS ("aplicação de normas de proteção dos direitos de propriedade intelectual” e “obtenção e manutenção de direitos de propriedade intelectual e procedimentos ‘inter partes’ conexos”, respectivamente).

O TRIPS incorporou ${ }^{187}$ a Convenção de Berna sobre direitos autorais, acrescentando proteção para software, bases de dados e gravações sonoras. No tocante às

\footnotetext{
${ }^{185}$ HUDEC, Robert E. International Economic Law: The Political Theatre Dimension. In: University of Pennsylvania Journal of International Economic Law, v. 17, n. 1, 1996, p. 12-14.

${ }^{186}$ LOWENFELD, Andreas F. International Economic Law, p. 196

${ }^{187} \mathrm{O}$ artigo 2 do TRIPS dispõe sobre a incorporação de tratados anteriores:
} 
patentes, foram adotados os padrões da Convenção de Paris, aumentando os assuntos tratados e o período de proteção. ${ }^{188}$

O trecho abaixo destaca a importância do TRIPS:

[I]t is crucially important for four reasons: (1) it establishes an international law of substantive minimum Standards for national IP laws; (2) it establishes minimum international criteria for national enforcement of IP rights through civil, criminal, and administrative proceedings; (3) it subjects national IP standards and enforcement to the WTO dispute settlement system, thereby providing an international forum for enforcement of rights and resolution of disputes; and (4) it establishes certain common procedural requirements that each national government must meet concerning the administration and maintenance of IP rights. The TRIPS does not unify IP, but it stipulates a certain harmonization on a worldwide basis. ${ }^{189}$

Do ponto de vista econômico, o direito à propriedade privada deve ser acompanhado por uma crença de que o direito à propriedade é seguro e que os benefícios econômicos do bem pertencem ao proprietário. Isso requer que as regras sejam cumpridas. Desse modo, observa-se que um dos aspectos do TRIPS refere-se à obrigação de os Estados promulgarem procedimentos de aplicação das regras, no âmbito civil e penal, para lidar com infrações aos direitos de propriedade intelectual. ${ }^{190}$

O aumento das penalidades decorrentes de infrações aos direitos de propriedade intelectual e a vinculação do TRIPS ao sistema de solução de controvérsias na OMC são considerados avanços na proteção aos direitos de propriedade intelectual. Conforme detalhado no item anterior, ambos os tópicos correspondem à vitória de um grupo de multinacionais, principalmente de setores de elevado grau tecnológico. Tais empresas, com respaldo de países desenvolvidos, enfrentaram resistência de países em desenvolvimento.

Implementado em um contexto de profunda assimetria mundial de distribuição de capacidade científica e tecnológica, ${ }^{191}$ o TRIPS também contém dispositivos condizentes com os interesses dos países em desenvolvimento. Nesse sentido, a inovação e a transferência de tecnologia são os objetivos do acordo, nos termos do seu artigo 7. Já o

“1 - Com relação às Partes II, III e IV deste Acordo, os Membros cumprirão o disposto nos Artigos 1 a 12 e 19, da Convenção de Paris (1967).

2 - Nada nas Partes 1 a IV deste Acordo derrogará as obrigações existentes que os Membros possam ter entre si, em virtude da Convenção de Paris, da Convenção de Berna, da Convenção de Roma e do Tratado sobre a Propriedade Intelectual em Matéria de Circuitos Integrados.”

${ }^{188}$ SELL, Susan K., Industry Strategies for Intellectual Property and Trade: The Quest for TRIPS, and PostTRIPS Strategies, p. 80.

189 MATSUSHITA, M.; SCHOENBAUM; Thomas J.; MAVROIDIS, Petros C. The World Trade Organization: Law, Practice, and Policy, p. 405.

190 DRAHOS, Peter. Securing the future of intellectual property: Intellectual property owners and their nodally coordinated enforcement pyramid. In: International Case Western Reserve Journal of International Law, v. 36, n. 1, 2004, p. 62.

191 CORREA, Carlos María. Implementing the TRIPS Agreement in the Patents Field: Options for Developing Countries. In: The Journal of World Intellectual Property, v. 1, n. 1, 2005, p. 75. 
artigo 8 do TRIPS permite flexibilidades favoráveis à proteção da saúde pública e proíbe abusos ao direito de propriedade intelectual. Ambos os dispositivos estão transcritos abaixo:

\section{ARTIGO 7}

\section{Objetivos}

A proteção e a aplicação de normas de proteção dos direitos de propriedade intelectual devem contribuir para a promoção da inovação tecnológica e para a transferência e difusão de tecnologia, em beneficio mútuo de produtores e usuários de conhecimento tecnológico e de uma forma conducente ao bem-estar social e econômico e a um equilíbrio entre direitos e obrigações.

\section{ARTIGO 8}

Princípios

1 - Os Membros, ao formular ou emendar suas leis e regulamentos, podem adotar medidas necessárias para proteger a saúde e nutrição públicas e para promover o interesse publico em setores de importância vital para seu desenvolvimento socioeconômico e tecnológico, desde que estas medidas sejam compatíveis com o disposto neste Acordo.

2 - Desde que compatíveis com o disposto neste Acordo, poderão ser necessárias medidas apropriadas para evitar o abuso dos direitos de propriedade intelectual por seus titulares ou para evitar o recurso a práticas que limitem de maneira injustificável o comércio ou que afetem adversamente a transferência internacional de tecnologia.

Assim, observa-se que o TRIPS apresenta flexibilidade em alguns dispositivos ${ }^{192}$, os quais permitem uma margem para implementar políticas nacionais relacionadas à propriedade intelectual. Ademais, a forma como os ditames de propriedade intelectual serão implementados nos países permite a criação de um ambiente inovador nos países em desenvolvimento, desde que a aplicação esteja em consonância com o TRIPS. ${ }^{193}$

De forma geral, observa-se que o TRIPS atendeu o interesse das multinacionais que dependem dos direitos de propriedade intelectual. Como demonstrado no item anterior, esse posicionamento prevaleceu nas negociações do acordo, levadas por meio de propostas dos países desenvolvidos.

As conquistas dos países desenvolvidos não se encerraram com o TRIPS. Outras vitórias ocorreram posteriormente, como a internalização do TRIPS em diversos Estados antes de expirar o período de transição para os países em desenvolvimento ${ }^{194}$ e a conclusão de acordos bilaterais com regras mais rígidas de propriedade intelectual.

Tal cenário evidencia a importância da propriedade intelectual para muitas multinacionais sediadas nos Estados Unidos e Europa. Esse fato é importante para

\footnotetext{
192 Incluindo a definição de invenção e aspectos sobre licença compulsória.

193 CORREA, Carlos María. Implementing the TRIPS Agreement in the Patents Field: Options for Developing Countries. In: The Journal of World Intellectual Property, v. 1, n. 1, 2005, p. 75-76.

${ }^{194}$ Idem, p. 75.
} 
compreender a dinâmica da retaliação cruzada em propriedade intelectual, explorada nos próximos capítulos. 


\section{PRECEDENTES DA RETALIAÇÃO CRUZADA EM PROPRIEDADE INTELECTUAL}

Em apenas três casos na OMC, dos mais de 460 existentes $^{195}$, foi autorizada a aplicação da retaliação cruzada em propriedade intelectual. Em todos eles, países em desenvolvimento (a saber, Equador, Antígua e Barbuda e Brasil) tiveram autorização do OSC para utilizar o mecanismo em face de países desenvolvidos (Estados Unidos e União Europeia).

\subsection{Retaliação cruzada em propriedade intelectual}

O objetivo deste capítulo é analisar os requisitos para aplicação da retaliação cruzada em propriedade intelectual. Essa análise é conduzida à luz dos três precedentes em que a medida foi autorizada no âmbito do OSC: EC - Bananas III, US - Gambling e US Cotton. Não por acaso, nesses três casos a retaliação cruzada foi requerida por um país em desenvolvimento em face de um país desenvolvido. ${ }^{196}$ A análise desses precedentes e de seus desdobramentos ilustra as dificuldades inerentes à retaliação cruzada.

\subsubsection{Histórico das negociações sobre a retaliação cruzada}

O fato de os três precedentes em retaliação cruzada em propriedade intelectual envolverem países em desenvolvimento, buscando compensação pelos danos causados por países desenvolvidos, torna-se interessante quando se nota que a inserção do mecanismo da retaliação cruzada no âmbito do OSC foi pleiteada por países desenvolvidos na Rodada do Uruguai. As nações desenvolvidas acreditavam que a retaliação cruzada era necessária para assegurar o cumprimento das regras relativas à propriedade intelectual (TRIPS), na medida

\footnotetext{
${ }^{195}$ Embora uma reduzida parte desses casos alcance a fase da retaliação, pois muitos deles encerram-se na etapa de consultas. Disponível em: <www.wto.org/english/tratop_e/dispu_e/dispu_status_e.htm>. Acesso em $14 / 08 / 2013$.

${ }^{196}$ A título exemplificativo, mais da metade das controvérsias na OMC (17 das 33 disputas) que versam sobre o TRIPS possuem os Estados Unidos como reclamante, o que denota a importância da propriedade intelectual para esse país. Mais informações disponíveis em: <www.wto.org/english/tratop_e/dispu_e/dispu_agreements_index_e.htm?id=A26\#selected_agreement>. Acesso em 13/08/2013.
} 
em que poderiam retaliar os países infratores em bens (GATT), itens mais sensíveis à economia dos países em desenvolvimento. ${ }^{197}$

Durante as negociações da Rodada Uruguai, os países em desenvolvimento, temendo que a retaliação cruzada fosse usada contra eles pelos motivos expostos acima, solicitaram que a aplicação da retaliação cruzada preenchesse determinados requisitos, como circunstâncias suficientemente graves e impraticabilidade ou ineficácia da retaliação no mesmo acordo. ${ }^{198}$

Ironicamente, a retaliação cruzada em propriedade intelectual tem correspondido a uma ameaça às economias desenvolvidas. Além disso, os requisitos negociados na Rodada Uruguai agora dificultam a implementação de retaliação cruzada em propriedade intelectual por países em desenvolvimento em face dos países desenvolvidos. Essa ironia é relevante para este estudo porque ilustra o complexo jogo de interesses que marca o comércio internacional.

\subsubsection{Requisitos da retaliação cruzada}

A implementação da retaliação deve ocorrer dentro de determinadas circunstâncias, obedecer um procedimento e preencher certos requisitos. As circunstâncias que ensejam a retaliação cruzada já foram descritas no capítulo 1. Em síntese, devem ser seguidas as seguintes etapas: (i) primeiro, a parte reclamante deve buscar retaliar no mesmo setor e acordo em que o painel ou o Órgão de Apelação constataram a infração ou outra anulação ou prejuízo [art. 22.3(a) do ESC]; (ii) se isso for impraticável ou ineficaz, deve-se procurar retaliar em outro setor dentro do mesmo acordo [art. 22.3(b) do ESC]; (iii) em último caso, a parte pode suspender concessões ou outras obrigações em outro acordo [art. 22.3(c) do ESC]. Nesse sentido, os árbitros do caso US - Gambling destacaram:

\footnotetext{
Esse dispositivo contém uma sequência de etapas que devem ser seguidas para uma suspensão de concessões ou outras obrigações consistente com a OMC. Em outras palavras, o artigo 22.3 do ESC fornece uma hierarquia de mecanismos que a parte reclamante deve seguir ao determinar quais setores ou sob qual acordo a suspensão de concessões ou outras obrigações é pleiteada, qual seja: (1) buscar a
}

197 ÁRABE NETO, Abrão M. Cumprimento das decisões do sistema de solução de controvérsias da Organização Mundial do Comércio: análise das medidas de indução e das propostas para seu aprimoramento sob a perspectiva dos países em desenvolvimento. Tese de mestrado não publicada, Pontifícia Universidade Católica de São Paulo, 2008, p. 171.

198 SUBRAMANIAN, Arvind; WATAL, Fayashree. Can TRIPS serve as an enforcement device for developing countries in the WTO? In: Journal of International Economic Law, v. 3, n.3, 2000, p. 410. 
suspensão no mesmo setor e mesmo acordo; (2) buscar suspensão no mesmo acordo; e (3) buscar suspensão em outro acordo. ${ }^{199}$

A hipótese descrita no artigo 22.3(c) do ESC corresponde à retaliação cruzada. A retaliação cruzada em propriedade intelectual remete à suspensão de concessões ou outras obrigações no TRIPS, quando a infração ou outra anulação ou prejuízo forem encontradas em acordo da OMC diverso do TRIPS.

Para aplicar a retaliação cruzada, a parte deverá fundamentar seu pedido. ${ }^{200}$ Destaca-se que, nos termos do artigo 22.3 do ESC, há certa margem de apreciação para a parte reclamante (conforme os trechos constantes nos artigos 22.3 (b) e (c): "se a parte considera”). ${ }^{201}$ Os árbitros do caso EC - Bananas III salientaram que o artigo 22.3 apresenta "uma sequência de etapas para tornar a suspensão de concessões ou outras obrigações em consonância com a OMC, considerando a margem de apreciação da parte reclamante e da revisão dos árbitros, se um pedido de suspensão nos termos do artigo 22.2 do ESC for contestado no âmbito do artigo 22.6 do ESC”. ${ }^{202}$ Os árbitros dos casos US - Gambling e US - Cotton corroboraram, neste aspecto, a decisão da controvérsia. ${ }^{203}$

Além disso, é necessário cumprir determinados requisitos. Ao analisar a possibilidade de aplicar a retaliação cruzada, os árbitros da disputa US - Cotton ressaltaram que os dois requisitos do artigo 22.3(c) do ESC são cumulativos, ou seja, a parte reclamante deve considerar se "é impraticável ou ineficaz” suspender concessões ou outras obrigações no mesmo acordo e se "as circunstâncias são suficientemente graves”. O requisito adicional, previsto no artigo 22.3(d) do ESC, de considerar certos critérios, qualifica o modo que o artigo 22.3(c) do ESC deve ser aplicado. ${ }^{204} \mathrm{O}$ primeiro requisito é analisado a seguir.

\subsubsection{Praticabilidade}

\footnotetext{
${ }^{199}$ WT/DS267/ARB/1, parágrafo 5.62 . Tradução livre de "'[T]hese provisions imply a sequence of steps towards WTO-consistent suspension of concessions or other obligations'. In other words, as Antigua has expressed it, Article 22.3 of the DSU provides a 'hierarchy' of remedies that a complaining party must follow in determining in which sectors or under which agreements suspension of concessions or other obligations can be sought, namely (1) seek to suspend in the same sector in the same agreement, (2) seek to suspend within the same agreement and (3) seek to suspend under another agreement."

${ }^{200}$ Artigo 22.3(e) do ESC.

${ }^{201}$ WT/DS267/ARB/1, parágrafos 5.48 .

${ }^{202}$ WT/DS267/ARB/1, parágrafos 5.49 .

${ }^{203}$ WT/DS267/ARB/1, parágrafos 5.50 .

${ }^{204}$ WT/DS267/ARB/1, parágrafo 5.68.
} 
Nos termos do artigo 22.3(c), a parte poderá solicitar a retaliação cruzada se considerar "que é impraticável ou ineficaz suspender concessões ou outras obrigações relativas a outros setores abarcados pelo mesmo acordo abrangido”.

O significado usual do termo “praticável” é “disponível ou útil na prática; apto para ser usado" ou "inclinado ou adequado para ação em oposição à especulação etc.”. ${ }^{205} \mathrm{Na}$ análise da "praticabilidade” verifica-se se a suspensão no mesmo setor ou acordo pode ser aplicado na prática, assim como se é adequada para determinado caso concreto. Esse foi o entendimento dos árbitros nos casos EC - Bananas III, US - Gambling e US - Cotton. ${ }^{206}$

A impraticabilidade pode ser de fato (como na hipótese de a contramedida superar o montante da retaliação) ou legal. ${ }^{207}$ Um exemplo de impraticabilidade legal ocorre quando a suspensão de compromissos nos subsetores de serviços ou no tocante aos modos de serviço no qual determinada parte reclamante não está obrigada (por meio do cronograma do GATS) não é disponível para aplicação na prática e, portanto, é impraticável. $^{208}$

\subsubsection{Eficácia}

O termo "eficaz" significa "efeito poderoso", "causar uma forte impressão”, “ter efeito ou resultado”. ${ }^{209}$ Os árbitros do caso EC - Bananas III pautaram-se na comparação de definições para concluir que o sentido geral deste critério permite que a parte retaliante assegure que o impacto dessa suspensão é forte e possui o efeito desejado $^{210}$, qual seja, induzir o cumprimento das decisões do OSC em um período de tempo razoável. ${ }^{211}$ A decisão do caso EC - Bananas III definiu certas circunstâncias nas quais a parte reclamante deve considerar que a retaliação em determinado setor ou acordo não é “eficaz”: (i) quando houver, entre as partes, um considerável desequilíbrio em termos de volume de comércio e de poder econômico; e (ii) se a parte reclamante for muito dependente de importações da parte reclamada. ${ }^{212}$

\footnotetext{
${ }^{205}$ WT/DS27/ARB/ECU, parágrafo 72.

${ }^{206} \mathrm{WT} / \mathrm{DS} 267 / \mathrm{ARB} / 1$, parágrafo 5.71.

${ }^{207}$ WT/DS267/ARB/1, parágrafo 5.73 .

${ }^{208}$ WT/DS27/ARB/ECU, parágrafo 73.

${ }^{209}$ WT/DS27/ARB/ECU, parágrafo 74.

${ }^{210}$ Isso porque causaria mais efeitos perniciosos para a parte reclamante do que para a outra parte.

${ }^{211}$ WT/DS267/ARB/1, parágrafo 5.77.

${ }^{212}$ WT/DS27/ARB/ECU, parágrafo 75.
} 
Todavia, os árbitros do caso US - Cotton discordam do entendimento do árbitro da disputa EC - Bananas III, que afirmou que a parte reclamante deveria considerar o setor ou acordo no qual a suspensão seria menos prejudicial para si mesma. Como denotam os termos do artigo 22.3 (b) e (c) do ESC, o critério da “eficácia” envolve uma avaliação da eficácia - ou ausência dela - na suspensão no mesmo setor ou acordo, em vez da avaliação relativa da eficácia dessa suspensão, em comparação com a suspensão em outro setor ou acordo. Em outras palavras, os procedimentos e princípios do artigo 22.3 do ESC não permitem que a parte reclamante escolha livremente a suspensão no setor ou acordo mais eficaz. Na realidade, esse dispositivo permite que a parte reclamante busque outro setor ou acordo se considerar que a suspensão no setor ou acordo em que ocorreu a violação não é “praticável ou eficaz”. ${ }^{213}$

O caso US - Cotton corroborou o posicionamento dos árbitros da controvérsia EC - Bananas III que se a suspensão de certas concessões ou outras obrigações acarreta mais efeitos danosos para a parte retaliante do que para a outra parte, seria pertinente considerar a “eficácia” da mencionada suspensão. Além disso, conforme afirmam os árbitros de EC - Bananas III, deve haver situações em que, por exemplo, a parte reclamante é muito dependente das importações da outra parte, de tal forma que causará mais prejuízo para si mesma do que para a outra parte, na hipótese de suspensão de concessões ou outras obrigações em relação a tais importações. Nessa situação, em que a parte reclamante causaria a si mesma um prejuízo desproporcional, de modo que na prática estaria impossibilitada de retaliar, deve haver uma base que determine que essa suspensão não é “eficaz”. 214

No entanto, o caso US - Cotton asseverou que a retaliação sempre será prejudicial em determinada medida também para a parte retaliante. Porém, isso não significa que tal prejuízo não será relevante para o fim de determinar a “eficácia” da suspensão de determinado setor ou acordo. Ao estabelecer que a parte reclamante deve considerar se o mesmo setor ou acordo não é "praticável ou eficaz”, os formuladores do ESC reconheceram precisamente a possibilidade de circunstâncias nas quais a suspensão de certas obrigações não seria eficaz. Nestes casos a parte reclamante tem a possibilidade de usar um mecanismo eficaz, que produzirá os efeitos desejados. Isso inclui as situações

${ }^{213}$ WT/DS267/ARB/1, parágrafo 5.78.
${ }^{214}$ WT/DS267/ARB/1, parágrafo 5.79. 
em que o prejuízo de retaliar no mesmo setor ou acordo seria tão significativo para a parte reclamante que pode dissuadir tal parte de utilizá-lo. ${ }^{215}$

Isso está em consonância com o objetivo de induzir cumprimento, no qual esse dispositivo busca assegurar que a parte reclamante poderá efetivamente recorrer a uma medida autorizada. Simultaneamente, os árbitros da disputa US - Cotton atestaram que a probabilidade de cumprimento não estava em questão. Em vez disso, a controvérsia versava sobre a habilidade da parte reclamante de tornar eficaz o uso da contramedida concedida com o escopo de induzir tal cumprimento. ${ }^{216}$

\title{
3.1.2.3. Circunstâncias suficientemente graves
}

Além de demonstrar que a retaliação não cruzada seria ineficaz e impraticável, a parte deve demonstrar que “as circunstâncias são suficientemente graves” para justificar a suspensão de direitos e obrigações em outro acordo da $\mathrm{OMC}^{217}$. As decisões reconheceram que os termos acima possuem certo grau de flexibilidade ao determinar quais “circunstâncias” são pertinentes em determinado caso. Nesse sentido, os árbitros de US - Cotton corroboraram as seguintes determinações dos árbitros em US - Gambling:

\begin{abstract}
Nós também consideramos, de forma mais geral, que esse aspecto, relacionado às "circunstâncias", remete à necessidade de determinação no caso concreto e tais circunstâncias relevantes podem variar de caso para caso. Entretanto, destaca-se o termo "suficientemente", que sugere que apenas quando as circunstâncias adquirem certo grau de importância elas podem ser consideradas "suficientemente graves". 218219
\end{abstract}

No caso EC - Bananas III, os árbitros entenderam o termo "grave" como “importante, que tem consequências potencialmente importantes, sobretudo indesejáveis; que enseja preocupação; de grau ou montante significativo, digno de consideração", 220

Porém, o conceito de “circunstâncias" e o grau de "gravidade”, importantes para a análise do requisito em questão, permanecem indefinidos no subparágrafo (c) do

\footnotetext{
${ }^{215}$ WT/DS267/ARB/1, parágrafo 5.80 .

${ }^{216}$ WT/DS267/ARB/1, parágrafo 5.81 .

${ }^{217}$ WT/DS27/ARB/ECU, parágrafo 82.

218 Tradução livre de: "We also consider, more generally, that this aspect of the determination, which relates to "circumstances", is of necessity an assessment to be made on a case-by-case basis, and that the circumstances that are relevant may vary from case to case. We note however, that these circumstances should be serious "enough", which suggests that it is only when the circumstances reach a certain degree or level of importance, that they can be considered to be serious enough."

${ }^{219}$ WT/DS267/ARB/1, parágrafo 5.84 .

${ }^{220}$ WT/DS27/ARB/ECU, parágrafo 83.
} 
artigo 22.3 do ESC. Os fatores listados no subparágrafo (d) do artigo 22.3 do ESC fornecem ao menos parte do contexto para definir o significado desses termos. ${ }^{221}$

Assim, os árbitros consideraram que o comércio em questão e sua importância para a parte reclamante, bem como “os elementos econômicos mais gerais” relacionados à anulação ou prejuízo e às consequências econômicas dessa suspensão, devem ser relevantes ao analisar se "as circunstâncias são suficientemente graves”. 222

\subsubsection{Artigo 22.3 (d)}

O subparágrafo (d) do artigo 22.3 do ESC prevê:

(d) ao aplicar os princípios acima, a parte deverá levar em consideração:

(i) o comércio no setor ou regido pelo acordo em que o grupo especial ${ }^{223}$ ou órgão de Apelação tenha constatado uma violação ou outra anulação ou prejuízo, e a importância que tal comércio tenha para a parte;

(ii) os elementos econômicos mais gerais relacionados com a anulação ou prejuízo e as consequências econômicas mais gerais da suspensão de concessões ou outras obrigações.

Especificamente, o subparágrafo (i) do artigo 22.3(d) do ESC prevê que, ao aplicar os princípios estabelecidos nos subparágrafos (a) a (c), a parte reclamante deverá considerar, dentre outros fatores, o comércio no setor ou acordos nos quais foram identificadas práticas inconsistentes com os acordos da OMC, bem como a importância de tal comércio para essa parte. ${ }^{224}$

O primeiro elemento acima (o comércio no setor ou regido pelo acordo em que o painel ou Órgão de Apelação tenha constatado uma violação ou outra anulação ou prejuízo) deve ser interpretado consoante as definições dos termos “setor" e “acordo", contidas no artigo 22.3(g) do ESC. Conforme observam os árbitros de US - Gambling:

Com o intuito de determinar se a suspensão é praticável ou eficaz em determinado setor, é apropriado considerar todo o comércio no setor e sua importância para a parte reclamante. Isso também se encontra em consonância com o propósito desse dispositivo, que é fornecer certos parâmetros objetivos para guiar a conduta de tal determinação. ${ }^{225} 226$

\footnotetext{
${ }^{221}$ WT/DS267/ARB/1, parágrafo 5.82.

${ }^{222}$ WT/DS267/ARB/1, parágrafo 5.83.

${ }^{223}$ Grupo especial equivale a painel.

${ }^{224}$ WT/DS27/ARB/ECU, parágrafo 84.

225 Tradução livre de "[I]n order to determine whether suspension is practicable or effective in a certain sector, it is appropriate to take into account all the trade in that sector and its importance to the complaining party. This also appears to us consistent with the purpose of this provision, which is to provide certain objective parameters to guide the conduct of such determination."

${ }^{226}$ WT/DS267/ARB/1, parágrafo 5.86.
} 
Já o termo “tal comércio” refere-se ao comércio prejudicado ou anulado pela medida inconsistente com as regras da OMC.

O subparágrafo (ii) do artigo 22.3(d) do ESC requer que a parte reclamada considere os “elementos econômicos mais gerais” relacionados com a anulação ou prejuízo, bem como as “consequências econômicas mais gerais” da suspensão de concessões ou outras obrigações. Tendo em vista que o critério anterior (importância de tal comércio) está relacionado à “anulação ou prejuízo”, entende-se que esse fator (elementos econômicos mais gerais) diz respeito ao país que sofre a anulação ou prejuízo - ou seja, a parte retaliante. Nesse sentido, os árbitros do caso US - Cotton corroboraram a decisão de EC - Bananas III, reiterada também pelos árbitros de US - Gambling, segundo a qual:

O fato de que o critério anterior está relacionado à “anulação ou prejuízo” indica que esse fator concerne aos "elementos econômicos mais gerais” relacionados ao membro que sofre tal "anulação ou prejuízo”, que no caso é o Equador.

Nós acreditamos, porém, que o fato de que o último critério está relacionado à suspensão de concessões ou outras obrigações não é necessariamente uma indicação de que as "consequências econômicas mais gerais" referem-se exclusivamente à parte que descumpriu as regras da OMC, neste caso a Comunidade Europeia. Como ressaltado, a suspensão de concessões não deve afetar apenas a parte retaliada, mas deve ensejar também, pelo menos em certa medida, efeitos adversos para a parte reclamante que busca a suspensão, sobretudo se houver um considerável desequilíbrio em termos de volume de comércio e poder econômico entre as duas partes, como no caso em questão, em que as diferenças entre o Equador e a Comunidade Europeia quanto ao tamanho de suas economias e nível de desenvolvimento socioeconômico são substanciais. $^{227} 228$

Nos termos do artigo 22.3 (f), o termo setor é interpretado da seguinte forma:

(i) no que se refere a bens, todos os bens;

(ii) no que se refere a serviços, um setor principal dentre os que figuram na versão atual da "Lista de Classificação Setorial dos Serviços" que identifica tais setores;

(iii) no que concerne a direitos de propriedade intelectual relacionados com o comércio, quaisquer das categorias de direito de propriedade intelectual compreendidas nas Secções 1, 2, 3, 4, 5, 6 ou 7 da Parte II, ou as obrigações da Parte III ou da Parte IV do Acordo sobre TRIPS.

Conforme o artigo 22.3 (g) do ESC, o termo acordo deve ser entendido como:

227 Tradução livre de "The fact that the former criterion relates to 'nullification or impairment' indicates in our view that this factor primarily concerns 'broader economic elements' relating to the Member suffering such nullification or impairment, i.e. in this case Ecuador.

We believe, however, that the fact that the latter criterion relates to the suspension of concessions or other obligations is not necessarily an indication that "broader economic consequences" relate exclusively to the party which was found not to be in compliance with WTO law, i.e. in this case the European Communities. As noted above, the suspension of concessions may not only affect the party retaliated against, it may also entail, at least to some extent, adverse effects for the complaining party seeking suspension, especially where a great imbalance in terms of trade volumes and economic power exists between the two parties such as in this case where the differences between Ecuador and the European Communities in regard to the size of their economies and the level of socio-economic development are substantial."

${ }^{228}$ WT/DS267/ARB/1, parágrafo 5.88. 
(i) no que se refere a bens, os acordos enumerados no Anexo 1A do Acordo Constitutivo da OMC, tomados em conjunto, bem como os Acordos Comerciais Plurilaterais na medida em que as partes em controvérsia sejam partes nesses acordos;

(ii) no que concerne a serviços, o GATS;

(iii) no que concerne a direitos de propriedade intelectual, o Acordo sobre TRIPS.

É importante destacar que o grau da retaliação deverá ser equivalente ao grau de anulação ou prejuízo da prática inconsistente aos acordos da OMC. ${ }^{229}$ Além disso, a retaliação deverá ser temporária e perdurar até: (i) a supressão da medida incompatível com o acordo da OMC; (ii) que o retaliado forneça uma solução para a anulação ou prejuízo dos benefícios; ou (iii) que seja encontrada uma solução mutuamente satisfatória. Adicionalmente, o OSC deverá manter sob supervisão a implementação das recomendações e decisões adotadas, inclusive quando houver retaliação aplicada. ${ }^{230}$

Se o membro passível de retaliação impugnar o grau de suspensão proposto ou alegar que não foram observados os princípios e procedimentos do artigo 22.3 do ESC, a questão será remetida à arbitragem. As concessões e outras obrigações não deverão ser suspensas durante a arbitragem. ${ }^{231}$

O árbitro não deverá examinar a natureza das concessões ou das outras obrigações a serem suspensas, mas deverá verificar se o grau de tal suspensão é equivalente ao grau de anulação ou prejuízo. Caso a questão submetida à arbitragem inclua a reclamação de que não foram observados os princípios e procedimentos previstos no artigo 22.3 do ESC, o árbitro deverá examinar a reclamação. A decisão do árbitro será definitiva e as partes não deverão procurar outra arbitragem. Após a decisão, o OSC deverá, caso solicitado, outorgar autorização para a retaliação (quando a solicitação estiver em consonância com a decisão arbitral), exceto se o OSC rejeitar por consenso a solicitação. $^{232}$

Nos próximos itens, analisa-se a interpretação dos requisitos e procedimentos mencionados acima à luz dos três precedentes da retaliação cruzada em propriedade intelectual na OMC.

\footnotetext{
${ }^{229}$ Artigo 22.4 do ESC.

${ }^{230}$ Artigo 22.8 do ESC.

231 Artigo 22.6 do ESC.

${ }^{232}$ Artigo 22.7 do ESC.
} 


\subsection{EC - Bananas III (Equador)}

No primeiro caso (EC-Bananas $I I^{233}$ ), o Equador, um dos maiores produtores de bananas do mundo, questionou no OSC o caráter discriminatório do regime de importação de bananas que havia na Comunidade Europeia. ${ }^{234}$ A disputa refere-se às preferências concedidas às ex-colônias europeias na importação do produto em questão. ${ }^{235}$

\subsubsection{Síntese do caso}

A disputa versava sobre o regime vigente na Comunidade Europeia relativo à importação, distribuição e vendas de bananas, estabelecido em julho de 1993 por meio do Regulamento $n^{\circ}$ 404/93. A Comunidade Europeia concedia preferência para suas antigas colônias. O Equador e outros países que iniciaram a disputa não preenchiam os requisitos para obter tais preferências e realizaram um pedido de consultas na OMC. ${ }^{236}$

Iniciada em 1996, a controvérsia envolve Equador, Guatemala, Honduras, México e Estados Unidos em face da Comunidade Europeia. Foi alegada a violação ao GATT (artigos I, III, X e XIII), GATS (artigos II e XVII), Acordo sobre Agricultura (artigo 19), TRIMS (artigos 2 e 5) e Acordo sobre Licenciamento (artigo 1.3). ${ }^{237}$

Em 1997 foram divulgados os relatórios dos painéis relativos ao Equador e aos Estados Unidos. Meses depois, foram divulgados e adotados os relatórios do Órgão de Apelação dos Estados Unidos e do Equador. As decisões da OMC atestaram que a Comunidade Europeia violou determinadas regras. A disputa também teve recursos ao artigo 21.5 do ESC, mas a autorização para implementar a retaliação cruzada em propriedade intelectual ocorreu na arbitragem (envolvendo o artigo 22.6 do ESC).

A suspensão de concessões ou outras obrigações relativas ao TRIPS foi concedida na medida em que a retaliação nos setores e acordos da OMC que foram

\footnotetext{
233 DS 27, disponível em <www.wto.org/english/tratop_e/dispu_e/cases_e/ds27_e.htm>. Acesso em 28/01/2012.

${ }^{234}$ A União Europeia até 30 de novembro de 2009 era denominada oficialmente na OMC como Comunidade Europeia por razões legais. Para mais informações, vide: <www.wto.org/english/thewto_e/countries_e/european_communities_e.htm>. Acesso em 13/08/2013.

235 Mais detalhes sobre o caso podem ser obtidos em SALAS, Mauricio; JACKSON, John H. Procedural Overview of the WTO EC - Banana Dispute. In: Journal of International Economic Law, 2000, p. 145-166; O’CONNOR, Bernard. Remedies in the World Trade Organization Dispute Settlement System - The Bananas and Hormones Cases. In: Journal of World Trade, v. 38, n. 2, 2004, p. 245-266.

${ }^{236}$ WHITEMAN, Allison L., Cross Retaliation Under the TRIPS Agreement: An Analysis of Policy Options for Brazil. In: North Carolina Journal of International Law and Commercial Regulation, v. XXXVI, n. 1, 2010, p. 195.

${ }^{237}$ Informações disponíveis em < www.wto.org>. Acesso em 15/07/2013.
} 
violados fosse insuficiente para alcançar o prejuízo sofrido pelo Equador. ${ }^{238}$ Os elementos da permissão em questão serão analisados a seguir.

\subsubsection{Pedido de retaliação cruzada em propriedade intelectual}

Em novembro de 1999, o Equador solicitou autorização ao OSC para suspender concessões ou outras obrigações no âmbito do TRIPS, do GATS e do GATT no montante de US\$ 450 milhões. No tocante à retirada de concessões no setor de bens, o Equador afirmou que as suspensões não seriam praticáveis ou eficazes, e que as circunstâncias eram suficientemente graves para solicitar autorização para suspender concessões e outras obrigações relativas ao GATS e ao TRIPS. ${ }^{239}$ Como a disputa não versava sobre o acordo TRIPS, trata-se do primeiro caso em que foi solicitada autorização para realizar a retaliação cruzada em propriedade intelectual.

Em relação à suspensão dos direitos de propriedade intelectual, o Equador especificou que seu pleito abrangia as seguintes categorias estabelecidas na Parte II do TRIPS: (i) Seção 1 - Direito do autor e direitos conexos, especificamente o artigo 14 sobre a "Proteção de Artistas-Intérpretes, Produtores de Fonogramas (Gravações Sonoras) e Organizações de Radiodifusão”; (ii) Seção 3 - Indicações Geográficas; e (iii) Seção 4 Desenhos industriais. Concomitantemente, o Equador tentou reservar o direito de suspender concessões tarifárias ou outras obrigações tarifárias estabelecidas por meio do GATT para os casos em que isso fosse aplicável de modo praticável e eficaz. ${ }^{240}$

No tocante ao mencionado pedido de "reserva" feito pelo Equador, ainda que isso fosse permitido, seria inconsistente fazer um requerimento relacionado ao artigo 22.3(c) do ESC (que dispõe sobre a retaliação cruzada) - indicando que tal suspensão não seria praticável ou eficaz no mesmo setor e no mesmo acordo ou relacionada a outro acordo - e, simultaneamente, apresentar pedido pautado no artigo 22.3(a), indicando que a suspensão é praticável e eficaz no mesmo setor em que a violação fora praticada pela Comunidade Europeia. ${ }^{241}$

Todavia, não se exclui a possibilidade de que, uma vez determinado o montante de anulação ou prejuízo pelos árbitros, a suspensão seja praticável e eficaz no

\footnotetext{
${ }^{238}$ RUSE-KHAN, HENNING GROSSE. Suspending ip obligations under TRIPS: a viable alternative to enforce prevailing wto rulings? In: Center for International Environmental Law, April 2008, p. 2. Disponível em < www.ciel.org/Publications/TRIPS_IP_7May08.pdf>. Acesso em 15/07/2013.

${ }^{239} \mathrm{WT} / \mathrm{DS} 27 / \mathrm{ARB} / \mathrm{ECU}$, parágrafos 1-2.

${ }^{240} \mathrm{WT} / \mathrm{DS} 27 / \mathrm{ARB} / \mathrm{ECU}$, parágrafos 4-7.

${ }^{241}$ WT/DS27/ARB/ECU, parágrafo 32.
} 
mesmo setor no qual a violação ocorreu apenas para parte desse montante. Para o restante do referido montante, a suspensão seria praticável ou eficaz apenas em outros setores do acordo ou ainda em outro acordo. ${ }^{242}$ Nesse sentido, o pedido de reserva do Equador não é de todo inconsistente.

Um dos pontos contestados pela Comunidade Europeia é que o Equador não teria seguido os princípios e procedimentos constantes no artigo 22.3 do ESC ao suspender concessões e outras obrigações de setores ou acordos diferentes dos envolvidos na disputa. ${ }^{243}$ Assim, a questão foi levada à arbitragem, nos termos do artigo 22.6 do ESC. ${ }^{244}$ Nesse contexto, destaca-se o trecho abaixo do artigo 22.7 do ESC, sobre a atuação dos árbitros:

O árbitro que atuar conforme o parágrafo 6 não deverá examinar a natureza das concessões ou das outras obrigações a serem suspensas, mas deverá determinar se o grau de tal suspensão é equivalente ao grau de anulação ou prejuízo. O árbitro poderá ainda determinar se a proposta de suspensão de concessões ou outras obrigações é autorizada pelo acordo abrangido. No entanto, se a questão submetida à arbitragem inclui a reclamação de que não foram observados os princípios e procedimentos definidos pelo parágrafo 3 , o árbitro deverá examinar a reclamação. No caso de o árbitro determinar que aqueles princípios e procedimentos não foram observados, a parte reclamante os aplicará conforme o disposto no parágrafo 3. (...)

Ademais, as frases finais dos subparágrafos (b) e (c) do artigo 22.3 do ESC preveem que a parte reclamante "poderá procurar suspender concessões ou outras obrigações" e o subparágrafo (e) estabelece que se a parte decide requerer autorização para esse tipo de suspensão, "deverá indicar em seu pedido as razões que a fundamentam".

\subsubsection{Decisão sobre a retaliação cruzada}

Ao examinar o pleito da Comunidade Europeia de que o Equador não teria seguido os princípios e procedimentos estabelecidos nos subparágrafos (a-e) do artigo 22.3 do ESC, os árbitros decidiram analisar os seguintes aspectos:

(i) Se a suspensão de concessões no GATT (em um dos mesmos setores onde a violação foi encontrada pelo painel) não seria “praticável ou eficaz”;

(ii) Se a suspensão de compromissos no GATS em subsetor diferente de comércio a atacado dentro do setor de serviços de distribuição não seria “praticável ou eficaz”;

\footnotetext{
${ }^{242}$ WT/DS27/ARB/ECU, parágrafo 33.

${ }^{243}$ WT/DS27/ARB/ECU, parágrafo 10.

${ }^{244}$ WT/DS27/ARB/ECU, parágrafo 11.
} 
(iii) Se a suspensão de compromissos no âmbito do GATS em setor distinto de serviços de distribuição não seria "praticável ou eficaz”;

(iv) Se as “circunstâncias eram suficientemente graves” para buscar a retaliação em acordo diferente daqueles onde a violação foi confirmada;

(v) A “importância do comércio" para o Equador relativo aos setores e acordos violados;

(vi) Se os "elementos econômicos mais gerais" e as "consequências econômicas mais gerais” relativos à anulação ou prejuízo da retaliação solicitada foram considerados. ${ }^{245}$

Tais fatores remetem aos requisitos da retaliação cruzada em propriedade intelectual, que serão analisados a seguir. Como exposto, o propósito da presente dissertação é compreender aspectos sistêmicos do mecanismo em questão. Por esse motivo, serão analisados apenas os tópicos que cumpram essa função.

\subsubsection{Praticabilidade e eficácia}

Ao julgar o pedido da Comunidade Europeia, a interpretação dos árbitros dos critérios em questão ocorreu de modo consistente com o objeto e finalidade do artigo 22 do ESC, quais sejam, a indução de cumprimento. Isso porque se a parte reclamante selecionar setores ou acordos que não sejam praticáveis nem eficazes para retaliar, o objetivo de induzir cumprimento poderá não ser obtido e o mecanismo de aplicação de regras (“enforcement”) da OMC não terá funcionado. ${ }^{246}$

No caso do Equador, os árbitros entenderam que o artigo 22.3 do ESC estabelece os requisitos de praticabilidade e eficácia na negativa. Com base no subparágrafo (b) desse dispositivo, os árbitros afirmaram que as considerações do Equador precisam demonstrar que a suspensão não é praticável nem eficaz se aplicada no mesmo setor em que a violação foi detectada. Isso não significa que o Equador teria que demonstrar que essa suspensão seria praticável e eficaz em outros setores do mesmo acordo. Da mesma forma, o subparágrafo (c) do artigo 22.3 do ESC também só exige a demonstração de que a suspensão não á praticável ou eficaz em outros setores do mesmo

\footnotetext{
${ }^{245}$ WT/DS27/ARB/ECU, parágrafo 71.

${ }^{246}$ WT/DS27/ARB/ECU, parágrafo 78.
} 
acordo em que a violação foi encontrada, sem precisar demonstrar que a suspensão é praticável e eficaz em outro acordo. ${ }^{247}$

Desse modo, o Equador não precisava comprovar que a suspensão de concessões ou outras obrigações seria praticável ou eficaz no acordo TRIPS (já que as violações foram encontradas nos acordos GATT e GATS). O ônus da prova seria da Comunidade Europeia de estabelecer que a suspensão no mesmo setor ou acordo seria eficaz e praticável.

Por outro lado, consoante o artigo 22.3 (c) do ESC, cabe aos árbitros analisar a alegação do Equador de que “as circunstâncias são suficientemente graves” para justificar a suspensão em outros acordos. ${ }^{248}$

Ressalte-se também que os requisitos de praticabilidade e eficácia não estão estabelecidos nos subparágrafos (b) e (c) de forma isolada dos outros subparágrafos do artigo 22.3 do ESC. Esses critérios devem ser analisados de forma conjunta sobretudo com os fatores mencionados nos subparágrafos (i) e (ii) do artigo 22.3(d) do ESC, os quais devem ser considerados na suspensão de concessões ou outras obrigações prevista nos subparágrafos (a) a (c). ${ }^{249}$

Em relação aos aspectos peculiares do caso, o Equador afirmou que importava principalmente bens primários e de investimento da Comunidade Europeia. Nos últimos anos, afirmou que importou $85 \%$ de bens da Comunidade Europeia que não são classificados como de consumo. Assim, o Equador argumentou que a suspensão de concessões envolvendo tais bens não é praticável nem eficaz porque eles eram usados como insumo para a indústria doméstica e, assim, tarifas de importação proibitivas prejudicariam mais o retaliante do que o retaliado. ${ }^{250}$

Já a Comunidade Europeia contestou o percentual mencionado acima, destacando que ele seria inferior a 30\% (e não 85\% como afirmou Equador). Além disso, forneceu uma lista com países fornecedores que estariam mais próximos ao Equador ou que venderiam produtos mais baratos do que aqueles originários da Comunidade Europeia. $^{251}$

Os árbitros consideraram insuficientes as provas apresentadas pela Comunidade Europeia. A decisão menciona que se o fornecimento de bens similares a

\footnotetext{
${ }^{247}$ WT/DS27/ARB/ECU, parágrafo 79.

${ }^{248}$ WT/DS27/ARB/ECU, parágrafo 80.

${ }^{249} \mathrm{WT} / \mathrm{DS} 27 / \mathrm{ARB} / \mathrm{ECU}$, parágrafo 81.

${ }^{250}$ WT/DS27/ARB/ECU, parágrafo 91.

${ }^{251}$ WT/DS27/ARB/ECU, parágrafo 92-94.
} 
preços inferiores estivesse disponível, provavelmente os importadores equatorianos já teriam buscado tais fontes. ${ }^{252}$ Além disso, considerando que o Equador, um pequeno país em desenvolvimento, corresponde a uma reduzida proporção das exportações dos produtos analisados, a suspensão de concessões do Equador em relação à Comunidade Europeia não terá um efeito significativo sobre as exportações europeias. ${ }^{253}$

Pelos motivos mencionados acima, os árbitros entenderam que a Comunidade Europeia não comprovou que a suspensão de concessões no âmbito do GATT no tocante a bens primários e de investimento seria praticável ou eficaz para o para o Equador. ${ }^{254}$ Entretanto, em relação aos bens de consumo, a decisão entendeu que o Equador não seguiu os princípios e procedimentos estabelecidos no artigo 22.3 do ESC acerca da praticabilidade e eficácia da medida. ${ }^{255}$ Portanto, o Equador teria que buscar primeiramente retaliar nos bens de consumo, até o montante disponível, antes de buscar a retaliação cruzada.

Já em relação à suspensão de concessões ou outras obrigações no âmbito do GATS, decidiu-se que o Equador seguiu os princípios e procedimentos estabelecidos pelo artigo 22.3 do ESC para comprovar a praticabilidade e eficácia. ${ }^{256}$ Logo, foi preenchido o primeiro requisito da retaliação cruzada nas violações concernentes ao GATS.

Ao analisar se a suspensão de concessões ou outras obrigações do GATS era praticável ou eficaz para o Equador, os árbitros destacaram que tal suspensão seria possível apenas em relação aos setores e modos de prestação com os quais o Equador se comprometeu no seu cronograma. ${ }^{257}$

\subsubsection{Circunstâncias suficientemente graves}

$\mathrm{Na}$ disputa do Equador, os árbitros encontraram diretrizes para definir a gravidade das circunstâncias no artigo 22.3(d) do ESC, que, como visto no início deste capítulo, exige que a parte reclamante considere determinados fatores quando selecionar o setor(es) ou acordo(s) para solicitar autorização do OSC para retaliar. ${ }^{258}$

\footnotetext{
${ }^{252}$ WT/DS27/ARB/ECU, parágrafo 95.

${ }^{253}$ WT/DS27/ARB/ECU, parágrafo 97.

${ }^{254} \mathrm{WT} / \mathrm{DS} 27 / \mathrm{ARB} / \mathrm{ECU}$, parágrafo 98.

${ }^{255}$ WT/DS27/ARB/ECU, parágrafo 102-104.

${ }^{256}$ WT/DS27/ARB/ECU, parágrafo 105-106.

${ }^{257}$ WT/DS27/ARB/ECU, parágrafo 107-108.

${ }^{258}$ WT/DS27/ARB/ECU, parágrafo 123.
} 
As estatísticas apresentadas pelo Equador apontaram a desigualdade existente entre esse país e a Comunidade Europeia, demonstrando que as "circunstâncias são suficientemente graves”, na tentativa de justificar a retaliação cruzada. A população do Equador era de 12 milhões de habitantes, enquanto a da Comunidade Europeia era de 375 milhões. O Equador correspondia a menos de 0,1\% do comércio mundial de mercadorias, enquanto a Comunidade Europeia detinha cerca de $20 \%$. No tocante ao comércio de serviços, a Comunidade Europeia representava 25\% e o Equador não possuía estatística, já que era quase inexpressivo nessa área. O PIB do Equador em 1998 era de US\$ 20 bilhões, enquanto da Comunidade Europeia era de US\$ 7.996 bilhões. No mesmo período, o Equador tinha PIB per capita de US\$ 1.600 e a Comunidade Europeia de US\$22.500. ${ }^{259}$

Tais dados evidenciam a significativa diferença econômica entre um país em desenvolvimento e uma das maiores economias do mundo. Essas estatísticas corroboram a ideia de que não seria praticável ou eficaz para o Equador retaliar no âmbito do GATS ou para todas as categorias de produtos do GATT. A mesma lógica se aplica para a suspensão de obrigações do TRIPS por um país em desenvolvimento em uma situação de desigualdade econômica considerável entre as partes envolvidas. ${ }^{260}$

Nesse contexto, o Equador limitou seu pedido de suspensão no âmbito do TRIPS para apenas três áreas de proteção dos direitos de propriedade intelectual, nas quais as consequências desfavoráveis ao Equador e as dificuldades de implementar a suspensão parecem as menores possíveis. ${ }^{261}$

\subsubsection{3. "Tal comércio" e a "importância de tal comércio"}

Os árbitros julgaram apropriado considerar a proporção do comércio afetado pela medida inconsistente com as regras da OMC, praticada pela Comunidade Europeia, em relação ao total do comércio no setor e/ou acordo em questão. Todavia, como visto no início deste capítulo, o critério de "tal comércio" e a "importância de tal comércio", previstos no subparágrafo (i) do artigo 22.3(d) do ESC, para a parte reclamante referem-se ao comércio prejudicado ou anulado pela medida inconsistente com as regras da OMC.

À luz dessa interpretação, foi atribuída importância aos fatores listados no subparágrafo (i) do artigo 22.3(d) do ESC no caso em questão, no qual a parte reclamante é

\footnotetext{
${ }^{259}$ WT/DS27/ARB/ECU, parágrafo 127.

${ }^{260} \mathrm{WT} / \mathrm{DS} 27 / \mathrm{ARB} / \mathrm{ECU}$, parágrafo 128.

${ }^{261}$ WT/DS27/ARB/ECU, parágrafo 129.
} 
um país em desenvolvimento onde o comércio de bananas e os serviços relacionados ao fornecimento de bananas são muito mais importantes para esse país do que para a parte reclamada, sobre a qual recairia a suspensão. ${ }^{262}$

O Equador afirmou que o setor de bananas era essencial para sua economia. De fato, na época do contencioso o Equador era o maior exportador de bananas do mundo e o maior exportador desse produto para o mercado europeu. A produção de banana era também a maior fonte de empregos e de ganhos estrangeiros no país. Cerca de 11\% da população do Equador era totalmente dependente deste setor. As exportações de bananas representavam aproximadamente $25 \%$ do total de exportações de bens do Equador e a produção de bananas correspondia a 5,2\% do PIB. ${ }^{263}$

Embora os países em desenvolvimento (principalmente os menores) não comercializem o mesmo volume ou variedade de produtos que os países desenvolvidos, as barreiras comerciais que os países em desenvolvimento enfrentam podem ter maior impacto sobre suas economias. ${ }^{264}$

Assim, os árbitros julgaram que o Equador comprovou o requisito previsto no artigo 22.3(d)(i) do ESC, qual seja, "o comércio no setor ou regido pelo acordo em que o painel ou órgão de Apelação tenha constatado uma violação ou outra anulação ou prejuízo, e a importância que tal comércio tenha para a parte”. ${ }^{265}$

\subsubsection{Consequências e elementos econômicos mais gerais}

Neste caso, os árbitros entenderam que o fato do último requisito, previsto no art. 22.3.(d)(ii), estar relacionado à retaliação não indica necessariamente que as “consequências econômicas mais gerais" referem-se exclusivamente à parte que descumpriu as normas da OMC (neste caso, a Comunidade Europeia). A suspensão de concessões pode causar, além de consequência para a parte retaliada, efeitos adversos para a parte retaliante, sobretudo quando houver um considerável desequilíbrio em termos de volume de comércio e poder econômico entre as partes, como ocorre entre Equador e

\footnotetext{
${ }^{262}$ WT/DS27/ARB/ECU, parágrafo 86.

${ }^{263}$ WT/DS27/ARB/ECU, parágrafo 131.

${ }^{264}$ SHAFFER, Gregory. The challenges of WTO law: strategies for developing countries adaptation. In: World Trade Review, v. 5, n. 2, 2006, p. 178.

${ }^{265} \mathrm{WT} / \mathrm{DS} 27 / \mathrm{ARB} / \mathrm{ECU}$, parágrafo 132.
} 
Comunidade Europeia (tendo em vista o tamanho de suas economias e o nível de desenvolvimento socioeconômico). ${ }^{266}$

O Equador alegou que passava por uma das piores crises econômicas da sua história. De acordo com os árbitros, o dispositivo analisado não exige que a parte reclamante estabeleça um nexo causal entre a anulação ou prejuízo e "os elementos econômicos mais gerais”. Desse modo, foi considerado plausível o argumento do Equador que a anulação ou prejuízo causado pelas medidas inconsistentes com as regras da OMC relativas ao regime de importação da Comunidade Europeia agravou a crise econômica, tendo em vista a importância do comércio de bananas e seus serviços de distribuição correlatos para a economia do Equador. ${ }^{267}$

No tocante às “consequências econômicas mais gerais” da suspensão de concessões ou outras obrigações, o Equador alegou que tais consequências praticamente não existiriam para a Comunidade Europeia, diante da disparidade econômica entre as partes. Os árbitros acataram esse argumento e, em seguida, consideraram preenchidos os requisitos de "elementos econômicos mais gerais” e “consequências econômicas mais gerais” estabelecidos no artigo 22.3(d)(ii) do ESC. ${ }^{268}$

\subsubsection{Hipóteses em que poderá haver retaliação cruzada}

Em relação ao pedido do Equador ${ }^{269}$ no tocante ao artigo 22.2 do $\mathrm{ESC}^{270}$, os árbitros entenderam que o Equador não seguiu os princípios e procedimentos estabelecidos no artigo 22.3 do ESC, especificamente em relação à suspensão de concessões no âmbito do GATT relativa a bens de consumo.

Portanto, os árbitros concluíram que no caso em questão deveria ocorrer retaliação em bens e serviços até determinado montante. Para o restante, foi recomendado que o Equador solicitasse autorização ao OSC para, nos termos do artigo 22.3 do ESC,

${ }^{266}$ WT/DS27/ARB/ECU, parágrafo 88.

${ }^{267}$ WT/DS27/ARB/ECU, parágrafo 135.

${ }^{268}$ WT/DS27/ARB/ECU, parágrafo 136-137.

${ }^{269}$ WT/DS27/52.

270 Artigo 22.2. "Se o Membro afetado não adaptar a um acordo abrangido a medida considerada incompatível ou não cumprir de outro modo as recomendações e decisões adotadas dentro do prazo razoável determinado conforme o parágrafo 3 do Artigo 21, tal Membro deverá, se assim for solicitado, e em período não superior à expiração do prazo razoável, entabular negociações com quaisquer das partes que hajam recorrido ao procedimento de solução de controvérsias, tendo em vista a fixação de compensações mutuamente satisfatórias. Se dentro dos 20 dias seguintes à data de expiração do prazo razoável não se houver acordado uma compensação satisfatória, quaisquer das partes que hajam recorrido ao procedimento de solução de controvérsias poderá solicitar autorização do OSC para suspender a aplicação de concessões ou de outras obrigações decorrentes dos acordos abrangidos ao Membro interessado.” 
suspender suas obrigações no tocante ao TRIPS em relação a determinados setores, a saber: direito do autor e direitos conexos, previstos no artigo 14 da Seção 1 do TRIPS (proteção de artistas intérpretes, produtores de fonogramas - gravações sonoras - e organizações de radiodifusão), indicações geográficas (Seção 3) e desenhos industriais (Seção 4). ${ }^{271}$

\subsubsection{Considerações sobre a aplicação da retaliação em propriedade intelectual}

Observa-se que o Equador seguiu os princípios e procedimentos estabelecidos no artigo 22.3(c) do ESC necessários, neste caso, para pleitear autorização do OSC para suspender certas obrigações constantes no TRIPS. ${ }^{272} \mathrm{O}$ pedido do Equador para suspender as obrigações do TRIPS refere-se ao artigo 14 da Seção 1 do TRIPS (Direito do autor e direitos conexos), bem como à Seção 3 (indicações geográficas) e à Seção 4 (Desenhos industriais).

No tocante à proteção de artistas intérpretes, produtores de fonogramas (gravações sonoras) e organizações de radiodifusão, prevista no artigo 14 do TRIPS, ressalte-se que os critérios para elegibilidade da proteção de pessoas estão definidos na Convenção de Roma. ${ }^{273}$ Nesse contexto, vale destacar que, em caso de suspensão de obrigações relativas ao mencionado artigo 14, como solicitado pelo Equador, podem existir diversos titulares de diferentes direitos relacionados a fonogramas e tais titulares não necessariamente terão a nacionalidade (nos termos do artigo 1.3 do TRIPS) de um dos membros da Comunidade Europeia, ainda que o fonograma tenha sido produzido em um desses Estados membros. Situações como essa deverão ser cuidadosamente analisadas pelo Equador ao implementar a suspensão das obrigações do TRIPS para não prejudicar titulares de direitos que não sejam nacionais de Estados que não pertencem à Comunidade Europeia. $^{274}$

\footnotetext{
${ }^{271}$ WT/DS27/ARB/ECU, parágrafo 175.

${ }^{272}$ WT/DS27/ARB/ECU, parágrafo 139-140.

273 Convenção Internacional para a Proteção dos Artistas-Intérpretes, Produtores de Fonogramas e Organizações de radiodifusão, adotada em Roma em 26 de outubro de 1961. Disponível em: <www.wipo.int/wipolex/en/text.jsp?file_id=203658\#LinkTarget_111>. Acesso em 11/08/2013. O Brasil promulgou a Convenção de Roma por meio do Decreto n. 57.125/65. Disponível em: $<$ www2.camara.leg.br/legin/fed/decret/1960-1969/decreto-57125-19-outubro-1965-397457-retificacao51108-pe.html>. Acesso em 11/08/2013.

${ }^{274}$ WT/DS27/ARB/ECU, parágrafo 146.
} 
Em relação ao critério de elegibilidade para a proteção de desenhos industriais, a Convenção de Paris é a convenção relevante. ${ }^{275}$ Já a proteção legal de indicações geográficas é usufruída pelas “partes interessadas” nos termos dos artigos 22.2 e 23.1 do TRIPS. O artigo 22.1 do TRIPS estabelece uma clara relação entre a região, localidade ou território e uma indicação geográfica passível de proteção. Isso indica que uma suspensão da proteção de indicações geográficas pode preocupar partes interessadas que identificam um bem como originário de um território de um dos Estados-membros da Comunidade Europeia, ou região ou localidade naquele território. ${ }^{276}$

Cumpre elucidar que, em relação a todos os outros membros da OMC e às pessoas físicas ou jurídicas que não sejam nacionais da Comunidade Europeia, o Equador deve respeitar as obrigações previstas no TRIPS e todos os demais membros da OMC podem exercer seus direitos por meio do OSC em relação ao Equador. ${ }^{277}$

\subsection{Efeitos da retaliação cruzada sobre terceiros países}

Ao julgar o caso do Equador, os árbitros destacaram que, em decorrência da autorização do OSC para que o Equador suspendesse as obrigações estipuladas pelo artigo 14 do TRIPS, fonogramas podem ser produzidos em desrespeito ao referido artigo 14, mas de acordo com a autorização da retaliação cruzada da OMC. Entretanto, tais fonogramas ainda podem ser cópias feitas sem o consentimento dos titulares do direito ou de pessoa devidamente autorizada pelo titular do direito no país em que é fabricado. De acordo com a nota de rodapé $n^{\circ} 13$ do artigo 51 do TRIPS ${ }^{278}$, os membros da OMC não têm obrigação de aplicar procedimentos concernentes a exigências especiais relativas a medidas de fronteira para importações de bens colocados no mercado de outro país por meio de ou com consentimento do titular do direito. Entretanto, no tocante aos fonogramas produzidos no Equador sem o consentimento do titular do direito, mas em conformidade com a autorização concedida pelo OSC nos termos do artigo 22.7 do ESC, as obrigações do artigo 51 do TRIPS aplicáveis a tais procedimentos permanecem em vigor para todos os membros da OMC. ${ }^{279}$

\footnotetext{
${ }^{275}$ WT/DS27/ARB/ECU, parágrafo 147.

${ }^{276}$ WT/DS27/ARB/ECU, parágrafo 148.

${ }^{277}$ WT/DS27/ARB/ECU, parágrafo 149.

278 Referida nota de rodapé prevê:"13. Fica entendido que não haverá obrigação de aplicar esses procedimentos a importações de bens colocado no mercado de um terceiro país pelo titular do direito ou com o seu consentimento, nem a bens em trânsito."

${ }^{279}$ WT/DS27/ARB/ECU, parágrafo 157.
} 
Ademais, distorções em terceiros países podem ser evitadas se o Equador suspender os direitos de propriedade intelectual em questão apenas para fins de abastecimento do mercado doméstico. ${ }^{280}$

\subsection{Outras observações sobre a retaliação cruzada}

Na opinião dos árbitros, espera-se que o uso dos direitos de propriedade intelectual aumente no Equador como resultado da autorização do OSC para prática da retaliação cruzada. Isso porque essa medida permitirá o uso de tais direitos sem o pagamento da remuneração aos titulares de direitos da Comunidade Europeia e sem a autorização deles, desde que reduzam os preços para os produtos equatorianos que incorporarem direitos de propriedade intelectual detidos pela Comunidade Europeia. ${ }^{281}$

Caso o Equador tivesse autorização do OSC para suspender a aplicação de direitos conexos (nos termos do artigo 14) vis-à-vis a Comunidade Europeia, o país teria que considerar a implementação de um sistema no qual as empresas e indivíduos estabelecidos no Equador pudessem obter uma autorização do governo equatoriano para aplicar a suspensão de concessões oriundas do artigo 14 do TRIPS dentro do território equatoriano.

Essa autorização poderia ser concedida por meio de um sistema de licenciamento que limitasse a suspensão de concessões em termos de quantidade, valor e tempo. O governo equatoriano poderia reservar seus direitos para revogar essas licenças a qualquer tempo. Cada reprodução de uma gravação sob esse sistema de licenciamento poderia corresponder a um “montante de suspensão” equivalente ao valor dos direitos conexos de uma gravação sonora nova e comercialmente mais interessante. Para tal finalidade, o Equador poderia usar a média do valor dos direitos conexos de gravações sonoras na Europa estimada pela Federação Internacional da Indústria Fonográfica (International Federation of the Phonographic Industry - IFPI). Determinada proporção desse montante seria destinada ao artista-intérprete e outra parte (maior) corresponderia ao produtor. $^{282}$

Em relação às indicações geográficas, é possível que o Equador as utilize, mas não é possível reproduzir o produto original. O uso dessas indicações geográficas poderia

\footnotetext{
${ }^{280}$ WT/DS27/ARB/ECU, parágrafo 158.

${ }^{281}$ WT/DS27/ARB/ECU, parágrafo 162.

${ }^{282}$ WT/DS27/ARB/ECU, parágrafo 163.
} 
ser licenciado de modo similar ao mencionado no caso das gravações sonoras acima. Licenças poderiam ser concedidas para determinado produtor por certo valor, quantidade e tempo. As licenças poderiam ser concedidas para uso exclusivo do titular da licença e o governo equatoriano poderia reservar seus direitos de revogar tais licenças a qualquer tempo. O teste para determinar o nível de suspensão poderia considerar em que medida os produtos protegidos da Comunidade Europeia seriam substituídos por produtos não protegidos de outras origens. ${ }^{283}$

No que concerne aos desenhos industriais, o Equador pretende usar um sistema de licenciamento similar ao descrito acima, mesmo considerando que os efeitos econômicos de suspender a proteção dos desenhos industriais seriam limitados. ${ }^{284}$

Vale lembrar que, consoante o artigo 22.8 do ESC $^{285}$, uma autorização do OSC relativa a um pleito de suspensão de concessões ou outras obrigações é uma ação temporária que aguarda a remoção das medidas inconsistentes com a OMC, uma solução para a anulação ou prejuízo de benefícios ou uma solução mutuamente acordada. Tendo em vista essa natureza da suspensão de concessões ou outras obrigações, os atores econômicos no Equador devem estar cientes do caráter temporário da suspensão de certas obrigações do TRIPS de modo que minimize o risco de realizar investimentos e atividades que podem não ser viáveis no longo prazo. ${ }^{286}$

\subsubsection{Análise do caso}

O Equador obteve decisão favorável na OMC e, após verificar o não cumprimento pela Comunidade Europeia, solicitou autorização do OSC para adotar a retaliação cruzada em propriedade intelectual. Tal autorização foi concedida em decorrência da importância da exportação de bananas para a economia do Equador e o prejuízo que o país sofria com as restrições europeias. Como a retaliação em bens seria insignificante para a Comunidade Europeia, dada a diferença das economias entre as

\footnotetext{
${ }^{283}$ WT/DS27/ARB/ECU, parágrafo 164.

${ }^{284}$ WT/DS27/ARB/ECU, parágrafo 165.

${ }^{285}$ Artigo 22.8 do ESC: "A suspensão de concessões ou outras obrigações deverá ser temporária e vigorar até que a medida considerada incompatível com um acordo abrangido tenha sido suprimida, ou até que o Membro que deva implementar as recomendações e decisões forneça uma solução para a anulação ou prejuízo dos benefícios, ou até que uma solução mutuamente satisfatória seja encontrada. De acordo com o estabelecido no parágrafo 6 do Artigo 21, o OSC deverá manter sob supervisão a implementação das recomendações e decisões adotadas, incluindo os casos nos quais compensações foram efetuadas ou concessões ou outras obrigações tenham sido suspensas mas não tenham sido aplicadas as recomendações de adaptar uma medida aos acordos abrangidos."

${ }^{286}$ WT/DS27/ARB/ECU, parágrafo 167.
} 
partes, a retaliação cruzada em propriedade intelectual representava um meio eficaz para induzir o cumprimento da decisão da OMC.

Não obstante a facilidade legal para o Equador implementar esse poderoso mecanismo, tendo em vista a autorização da OMC e seu sistema interno que reconhece normas internacionais como autoexecutáveis ${ }^{287}$, o país optou por não utilizar efetivamente a ferramenta e celebrou um acordo com a Comunidade Europeia. ${ }^{288}{ }^{289}$ Mesmo assim, foi um importante precedente para os países em desenvolvimento, que passaram a vislumbrar a possibilidade de induzir o cumprimento de normas multilaterais de forma mais eficaz.

\section{3. $\quad$ US - Gambling (Antígua e Barbuda)}

A segunda controvérsia em que houve autorização para implantar a retaliação cruzada em propriedade intelectual remete a uma disputa entre Antígua e Barbuda (“Antígua”) em face dos Estados Unidos, relativa à prestação de serviços por meio de jogos e apostas, descrita abaixo. No período em que a controvérsia foi instaurada na OMC, Antígua realizava esforços para desenvolver o setor de jogos na internet com o intuito de compensar a perda de receita oriunda do turismo. ${ }^{290}$

\subsubsection{Síntese do caso}

No caso US - Gambling ${ }^{291}$, Antígua alegou que os Estados Unidos violaram regras do GATS, ao proibirem que os estadunidenses consumissem jogos e apostas da parte reclamante pela internet ${ }^{292}$, enquanto em muitos locais de seu território os jogos de azar eram permitidos. Antígua alegou que tais medidas eram aplicadas de forma discriminatória aos serviços estrangeiros em comparação com os domésticos. O demandante também afirmou que essas ações acarretaram perda de renda e de empregos. ${ }^{293}$

\footnotetext{
287 SUBRAMANIAN, Arvind; WATAL, Fayashree. Can TRIPS serve as an enforcement device for developing countries in the WTO?, p. 411.

288 RUSE-KHAN, HENNING GROSSE. Suspending ip obligations under TRIPS: a viable alternative to enforce prevailing wto rulings?

${ }^{289}$ Mais informações sobre o acordo estão disponíveis em:

<www.wto.org/english/tratop_e/dispu_e/cases_e/ds27_e.htm>. Acesso em 13/08/2013.

${ }^{290}$ BBC News. US warns Antigua and Barbuda over 'piracy site' plan. 9 de janeiro de 2013. Disponível em: $<$ www.bbc.co.uk/news/technology-21247683>. Acesso em 20/07/2013.

291 DS285. Mais informações sobre o caso, que teve início em 2003, podem ser obtidas em: <www.wto.org/english/tratop_e/dispu_e/cases_e/ds285_e.htm>. Acesso em 17/07/2013.

${ }^{292}$ Os Estados Unidos alegavam questões morais.

293 BBC News. US warns Antigua and Barbuda over 'piracy site' plan.
} 
Após análise do painel (em 2004) e do Órgão de Apelação (em 2005), houve divulgação do painel de implementação, em 2007 e, em seguida, de uma decisão arbitral, nos termos do artigo 22.6 do ESC. ${ }^{294}$

Depois da vitória na OMC e do descumprimento da decisão pelos Estados Unidos, Antígua teve a autorização para aplicar a retaliação cruzada em propriedade intelectual. Os árbitros determinaram que o nível anual de anulação ou prejuízo referente à Antígua neste caso é de US\$ 21 milhões. Tendo em vista que o país preencheu os requisitos da retaliação cruzada, previstos no artigo 22.3 do ESC, os árbitros afirmaram que Antígua poderia solicitar autorização ao OSC para suspender obrigações relativas ao TRIPS, em montante não superior a US\$ 21 milhões anuais. ${ }^{295}$ Até o momento, o país também optou por não aplicar a retaliação cruzada. Como o caso traz algumas lições para o Brasil, cabe analisar a decisão dos árbitros e seus desdobramentos.

\subsubsection{Pedido de retaliação cruzada em propriedade intelectual}

Após o painel de implementação entender que os Estados Unidos não cumpriram com as recomendações do OSC, em junho de 2007, Antígua requereu autorização ao OSC, nos termos do artigo 22.2 do ESC, para suspender as concessões e obrigações relacionadas dos Estados Unidos em relação à Antígua, ligadas ao GATS e ao TRIPS, no montante de US\$3.443 bilhões.

A petição de Antígua pautou-se no artigo 22.3 do ESC, itens "b” e “c”, requerendo autorização para suspender obrigações previstas tanto no GATS (acordo violado) quanto no TRIPS. Em seguida, Antígua esclareceu que desejava suspender apenas as obrigações elencadas no TRIPS ${ }^{296}$, o que representa um pedido de retaliação cruzada em propriedade intelectual.

Antígua sustentava que, diante da vasta diferença entre as economias de seu país e dos Estados Unidos, retaliações em bens e serviços provenientes dos Estados Unidos teriam um impacto negativo muito maior sobre o retaliante do que sobre o retaliado. Ressalte-se que menos de 0,02\% das exportações estadunidenses destinavam-se à Antígua, que poderia ser facilmente substituída por outro destino. ${ }^{297}$

\footnotetext{
294 DS 285. Mais informações sobre o caso, que teve início em 2003, podem ser obtidas em: <www.wto.org/english/tratop_e/dispu_e/cases_e/ds285_e.htm>. Acesso em 17/07/2013.

${ }^{295}$ WT/DS285/ARB, parágrafo 6.1.

${ }^{296}$ WT/DS285/ARB, parágrafo 2.17.

${ }^{297}$ WT/DS285/ARB, parágrafo 4.2.
} 
Antígua considerava que as circunstâncias eram suficientemente graves para justificar a suspensão de concessões ou obrigações de acordos distintos do GATS, requisito necessário à concessão da retaliação cruzada como visto no início deste capítulo. Em decorrência da ausência de recursos naturais no país, a economia de Antígua era dependente de serviços financeiros. ${ }^{298}$

Antígua também alegava que todo o montante da retaliação aplicado somente em serviços dos Estados Unidos não era praticável, nem eficaz, por diversos motivos. Um deles era a desproporção do impacto da retaliação em serviços, a qual prejudicaria a economia de Antígua e teria pouco ou nenhum efeito sobre a economia norte-americana. ${ }^{299}$

\subsubsection{Decisão sobre a retaliação cruzada}

O caso em questão reiterou parcialmente a decisão dos árbitros relativa ao contencioso EC - Bananas III, a qual considerou de forma mais abrangente os termos do artigo 22.3 do ESC e observou que:

these provisions imply a sequence of steps towards WTO-consistent suspension of concessions or other obligations which respects both a margin of appreciation for the complaining party as well as a margin of review by Arbitrators, if a request for suspension under Article 22.2 is challenged under Article 22.6. ${ }^{300}$

Em relação aos princípios e procedimentos estabelecidos no artigo 22.3 do ESC, a decisão pautou-se no entendimento assentado pelos árbitros no caso EC - Bananas III, definindo que a aplicação do artigo 22.3 do ESC exige que sejam seguidas as etapas previstas no próprio artigo. Em outras palavras, o artigo 22.3 do ESC contém uma "hierarquia” de soluções ${ }^{301}$ que a parte reclamante deve seguir ao determinar sobre quais setores ou acordos recairá a retaliação. ${ }^{302}$

Ademais, no caso US - Gambling, os árbitros mencionaram a referência ao termo "setor" feita no subparágrafo (b) ${ }^{303}$ do artigo 22.3 do ESC, que define o escopo de análise que será feita. Nos termos dessa decisão, o termo "setor” no artigo 22.3 do ESC

\footnotetext{
${ }^{298}$ WT/DS285/ARB, parágrafo 4.3.

${ }^{299}$ WT/DS285/ARB, parágrafo 4.4.

${ }^{300}$ Decisão arbitral, EC - Bananas III, (request by Ecuador), para. 55.

${ }^{301}$ Em primeiro lugar, deve-se buscar suspender concessões do mesmo setor e do mesmo acordo. Se não for possível, deve-se procurar retaliar no mesmo acordo. Em último caso, pode-se retaliar em outro acordo da OMC.

${ }^{302}$ WT/DS285/ARB, parágrafo 4.19.

303 Artigo 22.3(b) "se a parte considera impraticável ou ineficaz a suspensão de concessões ou outras obrigações relativas ao(s) mesmo(s) setor(es), poderá procurar suspender concessões ou outras obrigações em outros setores abarcados pelo mesmo acordo abrangido;"
} 
deve ser compreendido conforme a definição contida no seu subparágrafo (f $)^{304}$. Outrossim, afirmaram que para determinar se a retaliação é praticável ou eficaz em certo setor, é importante considerar todo o comércio neste setor e a sua importância para a parte reclamante. $^{305}$

No tocante ao requisito dos "elementos econômicos mais gerais relacionados com a anulação ou prejuízo” e “as consequências econômicas mais gerais”, os árbitros do caso US - Gambling corroboraram a decisão do caso EC - Bananas III, na qual os árbitros determinaram que "The fact that the former criterion relates to 'nullification or impairment' indicates in our view that this factor primarily concerns 'broader economic elements' relating to the Member suffering such nullification or impairment, i.e. in this case Ecuador.” 306

Por fim, os árbitros do caso US - Gambling determinaram que o subparágrafo (d) do artigo 22.3 requer que a parte reclamante considere os seguintes elementos:

(i) o comércio no setor relevante (como definido no subparágrafo “f”) e a importância de tal comércio para a parte reclamante (no caso em questão, Antígua), incluindo considerações relativas à importância daquele comércio para a parte reclamante e para a parte reclamada (Estados Unidos, no presente caso);

(ii) “Elementos econômicos mais gerais” relativos ao membro que sofre a anulação ou prejuízo (Antígua);

(iii) “Consequências econômicas mais gerais” da suspensão de concessões ou outras obrigações, tanto para a parte que não está respeitando as normas da OMC (Estados Unidos) quanto para a parte reclamante (Antígua). ${ }^{307}$

\footnotetext{
${ }^{304}$ Artigo 22.3. (f) "para efeito do presente parágrafo, entende-se por 'setor':

(i) no que se refere a bens, todos os bens;

(ii) no que se refere a serviços, um setor principal dentre os que figuram na versão atual da "Lista de Classificação Setorial dos Serviços" que identifica tais setores;

(iii) no que concerne a direitos de propriedade intelectual relacionados com o comércio, quaisquer das categorias de direito de propriedade intelectual compreendidas nas Seções 1, 2, 3, 4, 5, 6 ou 7 da Parte II, ou as obrigações da Parte III ou da Parte IV do Acordo sobre TRIPS."

${ }^{305}$ WT/DS285/ARB, parágrafo 4.34.

${ }^{306}$ WT/DS285/ARB, parágrafo 4.35.

${ }^{307}$ WT/DS285/ARB, parágrafo 4.37.
} 
A seguir, são analisados os requisitos mencionados acima.

\subsubsection{Praticabilidade e eficácia}

Em relação à análise sobre a ineficácia e impraticabilidade da suspensão de concessões e outras obrigações no âmbito do GATS, especificamente no tocante à suspensão em outros setores, Antígua demonstrou preocupação em relação aos efeitos adversos que poderia sofrer em decorrência da sua pequena e dependente economia. Diante desse argumento, os árbitros concordaram com a possibilidade de a retaliação no âmbito do mesmo acordo afetar a eficácia da suspensão. ${ }^{308}$

Ao acatar o argumento de Antígua, os árbitros mencionaram a decisão do caso EC - Bananas III, a qual declarou que em uma situação em que há desequilíbrio em termos de volume de comércio e poder econômico entre reclamante e reclamada e em situações em que a parte reclamante é muito dependente de importações da parte contrária, a suspensão de concessões ou outras obrigações pode acarretar efeitos mais prejudiciais para o retaliante do que para o retaliado. ${ }^{309}$ Naquele caso, os árbitros julgaram que, tendo em vista as circunstâncias, uma consideração da parte reclamante apontando determinado setor ou acordo em que provavelmente haverá menos prejuízo para ela mesma seria suficiente para analisar o requisito da eficácia, consoante os princípios e procedimentos estabelecidos no artigo 22.3 do ESC. ${ }^{310}$

Desse modo, os árbitros no caso US - Gambling julgaram plausíveis os argumentos da Antígua de que não era praticável ou eficaz suspender concessões ou outras obrigações em relação a outros setores do GATS. ${ }^{311}$

\subsubsection{Circunstâncias suficientemente graves}

Os árbitros do caso US - Gambling também analisaram outro requisito da retaliação cruzada, previsto no artigo 22.3 do ESC: “circunstâncias suficientemente graves”. Considerando que o texto do artigo não contém diretrizes expressas, os árbitros corroboraram o entendimento assentado na disputa EC - Bananas III, consoante o qual os fatores contidos no subparágrafo (d) do artigo 22.3 do ESC estabelecem algumas diretrizes.

\footnotetext{
${ }^{308}$ WT/DS285/ARB, parágrafo 4.89.

${ }^{309}$ EC - Bananas III (Ecuador) (Article 22.6 - EC), para. 73

${ }^{310}$ EC - Bananas III (Ecuador) (Article 22.6 - EC), para. 73

${ }^{311}$ WT/DS285/ARB, parágrafo 4.105.
} 
Desse modo, os árbitros entenderam que o comércio em questão e a sua importância para a parte reclamante, bem como os elementos econômicos mais gerais relativos ao reclamante e as consequências econômicas mais gerais da suspensão proposta para ambas as partes devem ser relevantes para determinar se as circunstâncias são “suficientemente graves”. 312

Com o intuito de comprovar a gravidade das circunstâncias, Antígua apresentou alguns dados comparando sua população, tamanho, produto interno bruto (PIB), exportações e importações com estatísticas dos Estados Unidos. Antígua também destacou que possui recursos naturais extremamente limitados e, portanto, importa produtos agrícolas para satisfazer a demanda doméstica. Além disso, o país possui uma economia muito dependente do turismo e serviços correlatos, incluindo hotel e restaurantes, sujeitos aos efeitos de fatores externos (como variações climáticas). Por fim, Antígua destacou a necessidade de diversificar sua economia e, nesse sentido, tentou desenvolver o comércio em serviços, incluindo jogos de azar. A esse respeito, Antígua afirmou ter inclusive recebido apoio dos Estados Unidos durante certo período para desenvolver sua indústria de jogos. ${ }^{313}$

Diante desses fatores, os árbitros entenderam que as circunstâncias para Antígua eram “suficientemente graves”, nos termos do artigo 22.3(c) do ESC. Ressaltaram que várias considerações feitas por Antígua salientam as dificuldades de encontrar uma forma para suspender concessões ou outras obrigações de modo praticável e eficaz no âmbito do GATS. Destacaram as relações comerciais extremamente desequilibradas na controvérsia em questão, o que torna mais difícil encontrar um modo de assegurar a eficácia da suspensão de concessões ou outras obrigações contra os Estados Unidos no mesmo acordo (GATS). Ademais, a dependência de Antígua de setores que poderiam ser utilizados em eventual retaliação no âmbito do GATS aumentaria a possibilidade de efeitos adversos para o retaliante. Tais condições encontram-se diretamente relacionadas à praticabilidade e à eficácia da suspensão no contexto do GATS, ou seja, corresponde a uma das condições para Antígua conseguir implementar a retaliação em outro acordo (cruzada). ${ }^{314}$

Em suma, no exame dos requisitos da aplicação da retaliação cruzada em propriedade intelectual por Antígua, os árbitros afirmaram que o país cumpriu as condições previstas no artigo 22.3 do ESC, já que as circunstâncias eram “suficientemente graves” e,

\footnotetext{
${ }^{312}$ WT/DS285/ARB, parágrafo 4.107.

${ }^{313}$ WT/DS285/ARB, parágrafos 4.109-111.

${ }^{314}$ WT/DS285/ARB, parágrafos 4.113-116.
} 
portanto, suspender concessões ou outras obrigações no mesmo setor ou acordo não seria praticável, tampouco eficaz. $^{315}$

\subsubsection{3. "Tal comércio" e a "importância de tal comércio"}

Em relação ao cumprimento dos requisitos do artigo 22.3(d) do ESC, novamente a interpretação realizada pelos árbitros da disputa EC - Bananas III foi considerada pelos árbitros do caso US - Gambling. No tocante ao artigo 22.3(d)(i) do $\mathrm{ESC}^{316}$, os árbitros de EC - Bananas III não excluíram a possibilidade de que a totalidade do comércio do setor relevante ou acordo fosse pertinente, mas consideraram que os critérios do dispositivo em questão referem-se principalmente ao comércio anulado ou prejudicado pela medida que viola as regras da OMC.

Contudo, os árbitros da disputa US - Gambling entenderam que o sentido comum dos termos do artigo 22.3(d)(i) do ESC remete à totalidade do comércio do setor no qual foi encontrada a violação. Segundo estes árbitros, isso estaria em consonância com o contexto do dispositivo analisado, bem como com sua função e objetivo. ${ }^{317}$

\subsubsection{Consequências e elementos econômicos mais gerais}

Os argumentos de Antígua relativos à eficácia e praticabilidade da suspensão de obrigações em outros setores do GATS tornaram importante a consideração dos “elementos econômicos mais gerais” (no caso, a condição da Antígua de pequena economia dependente). Por outro lado, havia também os potenciais efeitos adversos da suspensão sobre a economia de Antígua, contrastando com o impacto limitado que teria sobre os Estados Unidos, o que correspondia às “consequências econômicas mais gerais” da suspensão para ambas as partes. ${ }^{318}$

Como visto no início deste capítulo, “elementos econômicos mais gerais” e “consequências econômicas mais gerais” da retaliação são requisitos previstos no artigo 22.3(d)(ii) do ESC. Os árbitros do caso US - Gambling reiteraram, neste aspecto, a decisão de EC - Bananas III, abaixo transcrita:

The fact that the former criterion relates to 'nullification or impairment' indicates in our view that this factor primarily concerns 'broader economic elements'

\footnotetext{
${ }^{315}$ WT/DS285/ARB, parágrafos 4.117-119.

316 Especificamente os trechos ao "comércio no setor ou regido pelo acordo em que o painel ou Órgão de Apelação tenha constatado uma violação" e a "importância que tal comércio tenha para a parte”.

${ }^{317}$ WT/DS285/ARB, parágrafos 4.31-4.33.

${ }^{318}$ WT/DS285/ARB, parágrafo 4.103.
} 
relating to the Member suffering such nullification or impairment, i.e. in this case Ecuador.

We believe, however, that the fact that the latter criterion relates to the suspension of concessions or other obligations is not necessarily an indication that 'broader economic consequences' relate exclusively to the party which was found not to be in compliance with WTO law, i.e. in this case the European Communities. As noted above, the suspension of concessions may not only affect the party retaliated against, it may also entail, at least to some extent, adverse effects for the complaining party seeking suspension, especially where a great imbalance in terms of trade volumes and economic power exists between the two parties such as in this case where the differences between Ecuador and the European Communities in regard to the size of their economies and the level of socio-economic development are substantial. ${ }^{319}$

\subsubsection{Considerações sobre a implantação da retaliação cruzada}

No caso em questão, os Estados Unidos questionaram como Antígua asseguraria que a suspensão de concessões ou outras obrigações não excederia o nível de anulação ou prejuízo identificado pelo árbitro. Os Estados Unidos temiam que a suspensão do TRIPS pudesse estimular a pirataria na internet. ${ }^{320}$

Os Estados Unidos afirmavam que sem a supervisão do governo de Antígua, não haveria base para calcular o nível da suspensão ou para determinar se os operadores estariam abusando do direito de suspender concessões do TRIPS oferecendo pirataria fora da jurisdição do retaliante. O país asseverou também que Antígua não havia nem começado a abordar tais questões. Os Estados Unidos também alegaram que a autorização para suspender concessões do TRIPS poderia encorajar a pirataria e que tal resultado não correspondia aos interesses legítimos dos membros da OMC. ${ }^{321}$

Por outro lado, Antígua alegava que as questões colocadas acima pelos Estados Unidos não estavam no termo de referência dos árbitros, consoante o artigo 22.7 do ESC. Argumentava também que restou estabelecido nos precedentes da OMC que a parte reclamante não precisa especificar precisamente quais obrigações pretende suspender. ${ }^{322}$ Antígua alegou que a autorização para retaliar não significa que o país efetivamente utilizará tal prerrogativa e, por isso, definiria a forma de retaliação quando fosse o momento apropriado. ${ }^{323}$

\footnotetext{
${ }^{319}$ WT/DS285/ARB, parágrafo 4.35-36.

${ }^{320} \mathrm{WT} / \mathrm{DS} 285 / \mathrm{ARB}$, parágrafo 5.3.

${ }^{321}$ WT/DS285/ARB, parágrafo 5.3.

${ }^{322}$ WT/DS285/ARB, parágrafo 5.4.

${ }^{323}$ WT/DS285/ARB, parágrafo 5.5.
} 
No pedido de autorização para suspender concessões ou outras obrigações, Antígua fez uma proposta de suspensão. Especificamente, indicou que adotaria contramedidas nas seguintes seções da parte II do TRIPS: (i) direito do autor e direitos conexos; (ii) marcas; (iii) desenhos industriais; (iv) patentes; e (v) proteção de informação confidencial. $^{324}$

Cabia à Antígua assegurar que a suspensão não excederia o montante autorizado pela OMC. O país se recusou a explicar de que forma aplicaria a mencionada suspensão e de que modo asseguraria que tal suspensão não ultrapassaria o valor autorizado pela OMC. ${ }^{325}$

Vale lembrar que o árbitro não tem competência para avaliar a natureza das obrigações que serão suspensas, nos termos do artigo 22.7 do ESC. Todavia, é importante que a forma escolhida para implementar a suspensão seja transparente, para que se permita verificar se o nível de retaliação não excedeu o nível de anulação. ${ }^{326}$

\subsubsection{Desdobramentos atuais do caso}

Em abril de 2012, foi anunciado em uma reunião do OSC, em nome de Antígua, que os Estados Unidos não cumpriram a decisão do painel, nem do Órgão de Apelação, tampouco do painel de implementação. Por essa razão, Antígua notificou formalmente os Estados Unidos sobre sua intenção de recorrer aos bons ofícios do DiretorGeral com o intuito de encontrar uma solução para a disputa. Antígua solicitou que o assunto fosse mantido sob supervisão do OSC. Em janeiro de 2013, Antígua pediu ao OSC autorização para retaliar ${ }^{327}$ os Estados Unidos em propriedade intelectual, que foi concedida, nos termos da decisão arbitral. ${ }^{328}$

Após mais de cinco anos de negociação, o governo de Antígua acredita que apenas o direito à aplicação da retaliação cruzada (reiterado em janeiro de 2013 pelo OSC) pode promover um avanço nas negociações com os Estados Unidos. ${ }^{329}$ Segundo o país, aparentemente os Estados Unidos não agiriam sem a pressão de serem retaliados. ${ }^{330}$ Por

\footnotetext{
$\overline{{ }^{324} \text { WT/DS285/ARB, parágrafo 5.6. }}$

${ }^{325}$ WT/DS285/ARB, parágrafo 5.8.

${ }^{326}$ WT/DS285/ARB, parágrafo 5.10.

${ }^{327}$ WT/DS285/25.

${ }^{328}$ Disponível em <www.wto.org/english/tratop_e/dispu_e/cases_e/ds285_e.htm>. Acesso em 20/07/13.

${ }^{329}$ WT/DS285/26 de 25 de abril de 2013.

${ }^{330}$ Inside U.S. Trade. Minister Says Engagement With U.S. Has Increased Since Antigua Signaled Intent To Retaliate In Gambling Case. 11 de fevereiro de 2013. Disponível em:
} 
sua vez, os Estados Unidos afirmaram que a retaliação reduzirá chances de ser celebrado um acordo entre as partes. ${ }^{331}$

Vale lembrar que a proposta de retaliação de Antígua envolve as seguintes seções (da parte II) do TRIPS: 1 (direito do autor e direitos conexos); 2 (marcas); 4 (desenhos industriais); 5 (patentes) e 7 (proteção de informação confidencial). ${ }^{332}$

Dentre as opções de retaliação, Antígua considera estabelecer um sítio na internet em que os usuários de todo o mundo poderiam baixar materiais protegidos por direitos autorais, como filmes, música ou software sem permissão de titulares estadunidenses. Outra opção seria recusar-se a registrar pedidos de patente ou de direitos autorais de titulares dos Estados Unidos. ${ }^{333}$

Nesse contexto, os Estados Unidos declararam que:

Moreover, if Antigua does proceed with a plan for its government to authorize the theft of intellectual property, it would only serve to hurt Antigua's own interests. Government-authorized piracy would undermine chances for a settlement that would provide real benefits to Antigua. It also would serve as a major impediment to foreign investment in the Antiguan economy, particularly in high-tech industries. ${ }^{334}$

Os Estados Unidos alegam que nunca tiveram a intenção de incluir jogos de azar e serviços de apostas no seu cronograma do GATS. Porém, a decisão do Órgão de Apelação definiu que o país havia se comprometido com o acesso a mercados de jogos de azar. Nesse cenário, os Estados Unidos invocaram o estabelecimento de procedimentos multilaterais para a modificação do seu cronograma de concessões do GATS. Em consonância com os procedimentos do GATS, os Estados Unidos celebraram um acordo ${ }^{335}$ com todos os membros interessados, com exceção de Antígua. ${ }^{336}$ Antígua alega que o

<insidetrade.com/201302112424298/WTO-Documents/Text-Document/minister-says-engagement-with-ushas-increased-since-antigua-signaled-intent-to-retaliate-in-gambling-case/menu-id-174.html>. Acesso em 21/07/2013.

${ }^{331}$ BBC News. US warns Antigua and Barbuda over 'piracy site' plan.

${ }^{332}$ Disponível em <www.antiguawto.com/wto/request_concessions.pdf>. Acesso em 20/07/13.

${ }^{333}$ Inside U.S. Trade. Antigua Mulls Retaliation Options In Gambling Dispute, Including Internet Site. 01 de fevereiro de 2013. Disponível em: <insidetrade.com/Inside-US-Trade/Inside-U.S.-Trade-02/01/2013/antiguamulls-retaliation-options-in-gambling-dispute-including-internet-site/menu-id-710.html>. Acesso em 20/07/2013.

${ }^{334}$ Inside U.S. Trade. U.S. Expresses Disappointment At Antigua Retaliation, Applauds China's Progress In Raw Materials Case. 21 de julho de 2013. Disponível em: <http://insidetrade.com/201301292422834/WTODocuments/Text-Document/us-expresses-disappointment-at-antigua-retaliation-applauds-chinas-progress-inraw-materials-case/menu-id-174.html>. Acesso em 21/07/2013.

${ }^{335}$ Concedendo compensações no âmbito do cronograma do GATS.

${ }^{336}$ Inside U.S. Trade. U.S. Expresses Disappointment At Antigua Retaliation, Applauds China's Progress In Raw Materials Case. 
acordo celebrado com os demais países, no âmbito do artigo XXI do GATS, está fora do escopo do que a economia de seu país pode fornecer. ${ }^{337}$

Por outro lado, um representante do governo de Antígua disse que o país é realista e não espera que os Estados Unidos mudem suas regras no curto prazo. Porém, a expectativa do país é de que haja uma negociação com ganhos razoáveis para ambas as partes. Nesse sentido, o país deixou clara a estratégia que está sendo utilizada:

\begin{abstract}
More to the point, the application of these trade remedies-commonly called "sanctions"-is designed to affect a totally unrelated, "innocent" sector of the offending country's economy for the failure of its Government to comply with rulings against it applicable to another sector. (...)

Therefore, according to the blueprint for these 'sanctions' established in the WTO agreements, domestic pressure from the innocent sector of the economy might be brought to bear on the responsible government, demanding conformity with an adverse WTO ruling.

In our particular case, the application of the 'sanctions'-the suspension of American intellectual property (IP) rights-should bring pressure by the US IP industry to bear on the Office of the US Trade Representative to comply with the rulings in our favour, or to at least to engage fairly with Antigua and Barbuda on a reasonable settlement. For why should, for example, Microsoft lose important intellectual property rights so that the United States Government can continue its protectionist policies benefiting its own domestic gaming interests? (...)

We are not simply hoping, however, and have developed a sound legal, public relations and lobbying campaign to ensure that our message goes forward quickly and clearly and our message does not get overtaken by the false information.

Finally, we are being proactive rather than reactive, and among our many strategies we are reaching out to potential allies in the global trading community for support, we are aggressively using the media to keep our message on track and we are developing strong, coherent and consistent lines of legal reasoning to ensure that our actions are free from serious criticism. ${ }^{338}$
\end{abstract}

Um representante da indústria disse que os titulares de direitos de propriedade intelectual dos Estados Unidos não pressionaram o USTR para negociar o caso com Antígua porque não faziam parte da disputa sobre serviços de jogos de azar. Simultaneamente, esses mesmos titulares defendem que as indústrias estadunidenses não tolerarão o “furto” de propriedade intelectual e, portanto, adotarão providências caso Antígua prossiga com a ideia de retaliar. ${ }^{339}$ Já um representante do governo de Antígua disse que em vez dos titulares dos direitos de propriedade intelectual estadunidenses buscarem medidas contra Antígua, eles deveriam concentrar esforços sobre o governo dos

\footnotetext{
${ }^{337}$ Inside U.S. Trade. U.S. Warns Antigua Not To Impose Retaliation In Years-Old Gambling Case. 21 de dezembro de 2012. Disponível em: <http://insidetrade.com/Inside-US-Trade/Inside-U.S.-Trade12/21/2012/us-warns-antigua-not-to-impose-retaliation-in-years-old-gambling-case/menu-id-710.html>.

Acesso em 20/07/2013.

${ }^{338}$ Inside U.S. Trade. Minister Says Engagement With U.S. Has Increased Since Antigua Signaled Intent To Retaliate In Gambling Case.

${ }^{339}$ Inside U.S. Trade. U.S. IP Holders Cite Legal Objections To Retaliation In Antigua Gambling Case. 15 de fevereiro de 2013. Disponível em: <http://insidetrade.com/Inside-US-Trade/Inside-US-Trade-02/15/2013/usip-holders-cite-legal-objections-to-retaliation-in-antigua-gambling-case/menu-id-710.html $>$. Acesso em 21/07/2013.
} 
Estados Unidos e seus operadores de jogos de azar, com o intuito de realizar um acordo entre os dois países envolvidos na controvérsia. ${ }^{340}$

Nesse sentido, o governo de Antígua anunciou no dia 17 de julho de 2012 a criação de uma comissão (WTO Remedies Implementation Committee - RIC), composta de diversos órgãos governamentais, responsável por supervisionar a implantação do processo de retaliação cruzada em propriedade intelectual em face dos Estados Unidos. ${ }^{341}$

Os Estados Unidos já tinham manifestado descontentamento com a possível retaliação, alegando que: (i) a medida não trará um resultado positivo para a economia e população de Antígua; (ii) a retaliação tornará mais difícil a resolução da disputa; e (iii) os países já estavam buscando um acordo. ${ }^{342343}$

A situação descrita acima evidencia a aplicação da teoria dos jogos de dois níveis, que será detalhada no próximo capítulo. O governo de Antígua evidenciou que está usando a (ameaça de) retaliação cruzada em propriedade intelectual como barganha para obter concessões relativas aos serviços de jogos de azar. Tal barganha pretende utilizar a força do setor privado norte-americano que detém direitos de propriedade intelectual sobre o governo dos Estados Unidos.

\subsection{US - Cotton (Brasil)}

O terceiro precedente em que foi autorizada da retaliação cruzada em propriedade intelectual corresponde ao contencioso do algodão, em que o Brasil questionou certas práticas ilegais dos Estados Unidos.

\subsubsection{Síntese do caso}

Em 2002, o Brasil solicitou consultas com os Estados Unidos em relação aos subsídios proibidos e acionáveis referentes ao algodão “upland” ${ }^{\text {344 }}$, que incluíam créditos à exportação, concessões e outros tipos de assistência aos produtores e exportadores de

\footnotetext{
${ }^{340}$ Inside U.S. Trade. U.S. IP Holders Cite Legal Objections To Retaliation In Antigua Gambling Case..

${ }^{341}$ Inside U.S. Trade. Antiguan Government Announces Formation of WTO Remedies. 17 de julho de 2013. Disponível em: <http://insidetrade.com/iwpfile.html?file=jul2013\%2Fwto2013_2267a.pdf>. Acesso em 20/07/2013.

${ }^{342}$ Inside U.S. Trade. U.S. Expresses Disappointment At Antigua Retaliation, Applauds China's Progress In Raw Materials Case.

343 Até a conclusão da presente dissertação, o caso continuava em andamento.

344 "Upland” corresponde à espécie de algodão que era mais plantada na época. Nesse sentido, vide: WHITEMAN, Allison L., Cross Retaliation Under the TRIPS Agreement: An Analysis of Policy Options for Brazil. In: North Carolina Journal of International Law and Commercial Regulation, p. 200.
} 
algodão. ${ }^{345} \mathrm{O}$ Brasil alegava que esses benefícios violavam os seguintes acordos da OMC: GATT, ASMC e o Acordo sobre Agricultura. A controvérsia, que versava sobre bens, é um dos precedentes da autorização de retaliação cruzada em propriedade intelectual. ${ }^{346}$

Em 2003, foi estabelecido o painel da disputa. A decisão, divulgada em 2004, foi favorável ao Brasil. Em síntese, foram identificados programas de garantia de crédito à exportação e de outros tipos que configuravam subsídios. Tais incentivos prejudicavam seriamente o Brasil, pois reduziam o preço do algodão no mercado mundial. ${ }^{347}$

Os Estados Unidos apelaram e, em 2005, foi divulgado o relatório do Órgão de Apelação que manteve a maioria das decisões do painel. Os Estados Unidos tiveram seis meses após a adoção do painel (que ocorreu em março de 2005) para remover os seguintes subsídios proibidos: (i) garantias de crédito à exportação concedidas no âmbito do GSM 102, GSM 103 e SCGP no tocante às exportações de algodão “upland” e outros produtos agrícolas beneficiados por esses programas; (ii) pagamentos realizados a exportadores e a consumidores norte-americanos de algodão para cobrir a diferença entre os preços domésticos deste produto e os preços do algodão no mercado mundial (STEP 2) ${ }^{348}$. No tocante aos subsídios acionáveis, foi recomendado que os Estados Unidos adotassem as providências necessárias para remover os efeitos adversos de certos subsídios ou remover tais subsídios até setembro de 2005. ${ }^{349}$ Afirma-se que o sucesso do Brasil na disputa em questão está relacionado ao trabalho conjunto realizado entre governo e setor privado. ${ }^{350}$

As decisões do contencioso do algodão repercutiram de forma positiva sobre as negociações da Rodada Doha, pois legitimaram o pleito dos países em desenvolvimento em prol da liberalização agrícola e impulsionaram a mudança de postura dos Estados Unidos e da União Europeia nessas negociações. ${ }^{351}$ Portanto, o caso teve impacto sistêmico positivo, destacado a seguir:

Nesse caso, olhando para o futuro, o contencioso do algodão terá certamente
impacto duradouro. Primeiramente, estabeleceu precedentes que permitirão a
outros países questionar na OMC os subsídios predatórios de países
desenvolvidos no setor agrícola. Mas, além disso, contribuiu para a iniciativa
africana em Cancun, que provocou o impasse nas negociações, estabelecendo as

\footnotetext{
345 Acerca dos subsídios questionados vide: O Estado de S. Paulo. Brasil pedirá avaliação da OMC sobre subsídios de algodão. 7 de agosto de 2006. Disponível em: $<$ www.estadao.com.br/arquivo/economia/2006/not20060807p37450.htm>. Acesso em 14/08/2013. ${ }^{346}$ Disponível em <www.wto.org/english/tratop_e/dispu_e/cases_e/ds267_e.htm>. Acesso em 21/07/13.

347 Disponível em <www.wto.org/english/tratop_e/dispu_e/cases_e/ds267_e.htm>. Acesso em 21/07/13.

${ }^{348}$ No âmbito da Seção 1207(a) de Farm Security and Rural Investment (FSRI) Act de 2002.

${ }^{349}$ Disponível em <www.wto.org/english/tratop_e/dispu_e/cases_e/ds267_e.htm>. Acesso em 21/07/13.

350 AZEVÊDO, Roberto. Depoimento. In: COSTA, Sérgio Rodrigues; BUENO, Miguel Garcia. A saga do algodão: das primeiras lavouras à ação na OMC. Rio de Janeiro: Insight Engenharia, 2004, p. 94.

${ }^{351}$ Idem, p. 93.
} 
condições necessárias à criação do G20 e à consequente elevação do Brasil a um papel de liderança nas negociações agrícolas e, posteriormente, em acesso a mercados. A partir de Cancun, o algodão passou a ser o único produto a ser tratado separadamente na Rodada de Doha, aumentando a visibilidade do problema dos subsídios. Isso, juntamente com a jurisprudência favorável do processo de solução de controvérsias, contribuiu decisivamente para a flexibilização das posições europeia e norte-americana em relação a subsídios domésticos e à exportação. ${ }^{352}$

Apesar disso, os Estados Unidos não se adequaram à decisão mencionada e em 2006 foi instaurado um painel de implementação. Em 2007 foi divulgado o relatório do referido painel, que teve a maioria das decisões favoráveis ao Brasil. Estados Unidos e Brasil apelaram. O relatório do Órgão de Apelação, divulgado em 2008, julgou que os Estados Unidos não se adequaram às recomendações do OSC, pois não removeram os subsídios. $^{353}$

Antes da etapa de implementação descrita acima, o Brasil solicitou autorização para retaliar, inclusive em propriedade intelectual, no tocante aos subsídios proibidos (em julho de 2005) e acionáveis (em outubro de 2005). O assunto foi remetido à arbitragem, que posteriormente foi suspensa. Em agosto de 2009, as decisões dos árbitros foram divulgadas aos membros. Tais decisões autorizaram a aplicação de retaliação cruzada em propriedade intelectual, quando a retaliação excedesse determinado montante anual.

Em novembro de 2009, o Brasil solicitou autorização ao OSC para retaliar, o que foi concedida. Em março de 2010, o Brasil notificou o OSC que retaliaria os Estados Unidos em bens a partir de abril. Contudo, em abril de 2010, o Brasil notificou o OSC sobre sua decisão de postergar a imposição de contramedidas devido às negociações entre os países envolvidos na disputa.

Em agosto de 2010, Brasil e Estados Unidos notificaram o OSC acerca da conclusão de um “Acordo-Quadro para uma Solução Mutuamente Acordada para o Contencioso do Algodão na Organização Mundial do Comércio (WT/DS267)”, que não constitui uma solução mutuamente acordada para a disputa (nos termos da OMC), mas estabelece parâmetros para discussões em prol de uma solução para o caso. No documento, restou acordada a realização de consultas bilaterais pelo menos quatro vezes por ano. ${ }^{354}$ Além disso, enquanto o Acordo-Quadro estiver em vigor, o Brasil não aplicará a retaliação autorizada pelo OSC.

\footnotetext{
${ }^{352}$ LIMA-CAMPOS, Aluisio G. de. Depoimento. In: COSTA, Sérgio Rodrigues; BUENO, Miguel Garcia. A saga do algodão: das primeiras lavouras à ação na OMC. Rio de Janeiro: Insight Engenharia, 2004, p. 116. 353 Disponível em <www.wto.org/english/tratop_e/dispu_e/cases_e/ds267_e.htm>. Acesso em 21/07/13. ${ }^{354}$ A menos que haja acordo em sentido contrário.
} 
Em uma reunião do OSC, o Brasil afirmou que em setembro de 2012 a Farm Bill de 2008 dos Estados Unidos expirou sem a promulgação de uma nova legislação. Tendo em vista que os programas agrícolas dos Estados Unidos não foram alterados, o Brasil decidiu manter o Acordo-Quadro e, portanto, não aplicar contramedidas até o momento.

Diante desse cenário, cumpre destacar a fundamentação da decisão ${ }^{355}$ que concedeu autorização para aplicar a retaliação cruzada em propriedade intelectual, o que será feito a seguir.

\title{
3.4.2. Pedido de retaliação cruzada em propriedade intelectual
}

O Brasil solicitou autorização para suspender concessões ou outras obrigações no GATT, no GATS e no TRIPS, nos termos do artigo 22.3(c) do ESC. Os Estados Unidos, por sua vez, afirmaram que o Brasil não seguiu os procedimentos do artigo 22.3 do ESC. Eles alegaram que, tendo em vista o tamanho e a diversidade da economia brasileira, o Brasil não consegue justificar e demonstrar que a retaliação em bens não é praticável ou eficaz. $^{356}$

O mandato para os árbitros analisarem tal controvérsia encontra-se no artigo 22.7 do ESC, transcrito abaixo:

\begin{abstract}
O árbitro que atuar conforme o parágrafo 6 não deverá examinar a natureza das concessões ou das outras obrigações a serem suspensas, mas deverá determinar se o grau de tal suspensão é equivalente ao grau de anulação ou prejuízo. O árbitro poderá ainda determinar se a proposta de suspensão de concessões ou outras obrigações é autorizada pelo acordo abrangido. No entanto, se a questão submetida à arbitragem inclui a reclamação de que não foram observados os princípios e procedimentos definidos pelo parágrafo 3, o árbitro deverá examinar a reclamação. No caso de 0 árbitro determinar que aqueles princípios e procedimentos não foram observados, a parte reclamante os aplicará conforme 0 disposto no parágrafo 3 . As partes deverão aceitar a decisão do árbitro como definitiva e as partes envolvidas não deverão procurar uma segunda arbitragem. O OSC deverá ser prontamente informado da decisão do árbitro e deverá, se solicitado, outorgar autorização para a suspensão de concessões ou outras obrigações quando a solicitação estiver conforme a decisão do árbitro, salvo se o OSC decidir por consenso rejeitar a solicitação. (grifos inexistentes no original)
\end{abstract}

\footnotetext{
${ }^{355}$ A decisão do caso considerou que não havia conflito entre os princípios e procedimentos contidos no artigo 22.3 do ESC e as regras do ASMC. Portanto, restou estabelecido que as normas previstas no artigo 22.3 do ESC eram aplicáveis ao caso em questão. Vide WT/DS267/ARB/1, parágrafos 5.1-5.2; 5.30-5.32.

${ }^{356}$ WT/DS267/ARB/1, parágrafos 5.1-5.2.
} 
Os árbitros no caso EC - Bananas III, ao definirem sua autoridade para analisar os princípios e procedimentos relativos à retaliação nos subparágrafos (b) e (c) do artigo 22.3 do ESC, consideraram que:

O fato de que o poder dos árbitros nos subparágrafos (b) e (c) está explicitamente previstos no artigo 22.6 implica a fortiori que a autoridade dos árbitros inclui o poder de rever se os princípios e procedimentos estabelecidos nesses subparágrafos foram seguidos pelo membro que busca autorização para suspensão." 357

Os Estados Unidos possuem o ônus de provar que o Brasil não seguiu os princípios e procedimentos constantes no artigo 22.3 do ESC. Simultaneamente, o Brasil deve demonstrar como fez essa determinação, fornecendo subsídios para que os árbitros analisem a questão e determinem se o Brasil "considerou os fatos objetivamente” e se poderia de forma plausível alcançar as conclusões que teve. ${ }^{358}$

Os Estados Unidos solicitaram que os árbitros indicassem, se necessário, o montante máximo da retaliação cruzada. Nesse contexto, é importante destacar que foram proferidas duas decisões, uma relacionada aos subsídios proibidos e outra concernente aos subsídios acionáveis. Assim, caso os Estados Unidos alterem apenas um tipo de subsídio, ainda haverá base legal para assegurar que as contramedidas são consistentes com os padrões do ASMC e do ESC. ${ }^{359}$ Para fins da retaliação cruzada no caso US - Cotton, deve ser considerada a soma da retaliação autorizada devido aos subsídios acionáveis e aos subsídios proibidos. ${ }^{360}$

Em seguida, os árbitros analisaram como o artigo 22.3 do ESC deveria ser aplicado. Para isso, verificou-se se as alegações das partes ensejariam a retaliação cruzada para o montante considerado apropriado. ${ }^{361}$

\subsubsection{Decisão sobre a retaliação cruzada}

A seguir serão analisados os requisitos da retaliação cruzada que foram analisados na decisão.

\subsubsection{Praticabilidade e eficácia}

\footnotetext{
${ }^{357}$ WT/DS267/ARB/1, parágrafos 5.47.

${ }^{358} \mathrm{WT} / \mathrm{DS} 267 / \mathrm{ARB} / 1$, parágrafos 5.55 .

${ }^{359} \mathrm{WT} / \mathrm{DS} 267 / \mathrm{ARB} / 1$, parágrafos 5.56 .

${ }^{360} \mathrm{WT} / \mathrm{DS} 267 / \mathrm{ARB} / 1$, parágrafos 5.96-103.

${ }^{361}$ WT/DS267/ARB/1, parágrafos 5.107-108.
} 
Os árbitros concordaram com o posicionamento dos Estados Unidos de que o mero custo adicional à economia brasileira não seria suficiente, por si só, para concluir que a suspensão de concessões ou outras obrigações não é “praticável ou eficaz”, nos termos do artigo 22.3 do ESC. Considerando que a imposição de uma barreira a determinadas importações geralmente acarreta custos econômicos aos membros que a impuseram, a suspensão de concessões no comércio de bens pode sempre ter o potencial de causar algum prejuízo à economia do membro que impõe barreiras. Ademais, os subparágrafos (b) e (c) do artigo 22.3 do ESC estabelecem circunstâncias específicas nas quais a parte reclamante pode ser autorizada a buscar a suspensão de concessões em outro setor ou acordo. ${ }^{362}$

A consideração dos custos econômicos associados com a suspensão é legítima, mas não é qualquer custo econômico relacionado à retaliação que enseja a conclusão de que tal suspensão é “impraticável ou ineficaz”. Os custos em questão devem ser de tal magnitude que tornem a retaliação “impraticável ou ineficaz”. 363

Os árbitros destacaram que o valor anual de importações de bens oriundos dos Estados Unidos representava mais de 15\% das importações brasileiras e menos de 2\% das exportações estadunidenses. Porém, os árbitros entenderam que apenas esse desequilíbrio apontado pelo Brasil não seria suficiente para concluir que a suspensão de concessões ou outras obrigações concernentes a tais bens seria uma "resposta ineficaz", como o Brasil argumentou. $^{364}$

Os árbitros também afirmaram que a “praticabilidade” está muito relacionada à possibilidade ou viabilidade na prática. Essa questão é parcialmente respondida pela análise do total de comércio, sobre o qual a suspensão de concessões ou outras obrigações pode incidir. Considerando que as importações brasileiras provenientes dos Estados Unidos excedem o valor total de importações sobre o qual a retaliação poderia ser aplicada, tal suspensão é, a princípio, possível. Já a eficácia está mais relacionada à possibilidade da parte reclamante efetivamente usar a autorização. Isso dependerá da medida em que tal parte causaria a si mesma um prejuízo significativo ao suspender concessões sobre as importações, de forma que essa suspensão não seria eficaz. ${ }^{365}$

Os árbitros destacaram, do mesmo modo que os árbitros no caso EC - Bananas III no tocante aos bens primários e de investimento, que a suspensão de concessões em relação aos bens de capital, intermediários ou outros insumos, os quais constituem insumos

\footnotetext{
${ }^{362}$ WT/DS267/ARB/1, parágrafo 5.131.

${ }^{363} \mathrm{WT} / \mathrm{DS} 267 / \mathrm{ARB} / 1$, parágrafo 5.133.

${ }^{364} \mathrm{WT} / \mathrm{DS} 267 / \mathrm{ARB} / 1$, parágrafo 5.139.

${ }^{365}$ WT/DS267/ARB/1, parágrafo 5.142.
} 
diretos para a produção doméstica, tem o potencial de prejudicar os operadores econômicos domésticos. Os árbitros acataram o argumento brasileiro acerca da dificuldade de buscar fornecedores alternativos para tais bens sem prejudicar significativamente a cadeia, embora notassem que tal assertiva teria menos relevância para bens primários, que são mais homogêneos. ${ }^{366}$ Assim, os árbitros aceitaram a posição brasileira de que seria impraticável ou ineficaz buscar a suspensão de concessões ou outras obrigações no tocante à importação de bens de capital, intermediários ou outros insumos essenciais à economia brasileira. $^{367}$

No tocante a bens de consumo, ressalta-se a decisão do caso EC - Bananas III:

A suspensão de concessões no tocante aos bens de consumo não pode causar efeitos adversos sobre a indústria do Equador. (...) Todavia, nota-se que o preço final resultante da suspensão de concessões em bens de consumo pode prejudicar consumidores finais nos países que suspenderam concessões. ${ }^{368} 369$

De forma semelhante, observa-se que os tipos de custos econômicos que os árbitros aceitaram, em relação a bens de consumo, não acarretam impactos similares à economia brasileira como aqueles causados pela retaliação em bens de capital, intermediários e insumos. Embora a suspensão gere aumento de preços que repercutem sobre o consumidor final, haverá prejuízo apenas se não houver nenhuma alternativa de substituição disponível por preço similar. ${ }^{370}$

Os árbitros afirmaram que a análise sobre a praticabilidade e eficácia da retaliação não está estritamente limitada à existência de fontes alternativas de suprimento, mas envolve uma consideração mais abrangente relacionada à viabilidade, na prática, para o Brasil, exigir que seus agentes econômicos busquem outros operadores, tendo em vista a gama de fatores que podem ser considerados nesta questão. ${ }^{371}$

A retaliação era praticável para US\$ 182,8 milhões de importações de bens de consumo oriundos dos Estados Unidos. ${ }^{372}$ O Brasil pleiteou a exclusão de importações de medicamentos, alimentos, livros, armas e automóveis da retaliação, setores nos quais barreiras à importação poderiam causar graves e desarrazoados custos para a economia brasileira. Os árbitros aceitaram as alegações brasileiras integralmente nos setores

\footnotetext{
${ }^{366}$ WT/DS267/ARB/1, parágrafos 5.149-150.

${ }^{367}$ WT/DS267/ARB/1, parágrafo 5.153.

368 Tradução livre de "Suspension of concessions with respect to consumer goods cannot cause any direct adverse effects on Ecuador's domestic manufacturing and processing industries. (...) It is also true that resulting price increases resulting from the suspension of concessions on consumer goods could cause welfare losses to end-consumers in the country suspending concessions".

${ }^{369}$ WT/DS267/ARB/1, parágrafo 5.159.

${ }^{370} \mathrm{WT} / \mathrm{DS} 267 / \mathrm{ARB} / 1$, parágrafo 5.160.

${ }^{371}$ WT/DS267/ARB/1, parágrafo 5.165.

${ }^{372}$ WT/DS267/ARB/1, parágrafo 5.166.
} 
automotivo $^{373}$ e de livros ${ }^{374}$. Entretanto, no que concerne a medicamentos ${ }^{375}$, alimentos ${ }^{376}$ e $\operatorname{armas}^{377}$, o Brasil não comprovou que a suspensão ocasionaria “custos graves e desarrazoados” para toda a gama de produtos desses setores. ${ }^{378}$

Não é qualquer custo econômico relacionado à suspensão de concessões ou outras obrigações em determinado setor que justifica a retaliação cruzada. Os custos em questão devem ser de tal magnitude que tornem a suspensão “impraticável ou ineficaz". Todavia, os árbitros entenderam que o Brasil teria uma quantidade suficiente de bens para escolher os setores em que retaliaria, sem incorrer em custos "graves ou desarrazoados" tendo em vista o volume de bens de consumo importados e o valor de retaliação autorizado. $^{379}$

No que concerne à inflação, os árbitros entendem que embora haja risco de aumento de preços decorrente da aplicação de contramedidas em bens, não atingirá um nível que impedirá a retaliação em bens. Os árbitros também salientaram que o índice de inflação é baseado no consumo doméstico, que é predominantemente formado por bens produzidos nacionalmente. Concluíram, assim, que a aplicação de contramedidas em bens teria um efeito limitado, tendo em vista a composição da cesta de bens que compõe o cálculo da inflação. ${ }^{380}$

\footnotetext{
373 Os árbitros destacaram que a participação dos produtos dos Estados Unidos no total das importações brasileiras do setor automotivo é de apenas 2 por cento. Eles asseveraram que a suspensão poderia ser prejudicial às subsidiárias brasileiras que importam carros, tendo em vista as operações intra-company que ocorrem no setor. Ademais, mencionaram que as autopeças de diferentes fabricantes não são necessariamente substituíveis entre si. Por tal motivo, o setor foi excluído da retaliação, pois poderia causar "graves e desarrazoados custos” ao Brasil. Vide WT/DS267/ARB/1, parágrafo 5.173.

${ }^{374} \mathrm{O}$ Brasil ressaltou o prejuízo que a retaliação acarretaria sobre a melhoria do padrão de educação. Ademais, o artigo 150 VI (d) da Constituição Federal estabelece imunidade (proibição de instituir impostos) sobre livros, jornais, periódicos e o papel destinado à sua impressão, o que torna inviável aplicar contramedidas sobre livros. Os árbitros observaram que livros são produtos infungíveis, impossibilitando a substituição entre tais bens. Entretanto, notaram que muitos livros possuem função de entretenimento em vez de educacional. Vide WT/DS267/ARB/1, parágrafo 5.172.

${ }_{375}$ Os árbitros concordaram com as alegações brasileiras sobre as especificidades do mercado de certos produtos farmacêuticos, o que pode dificultar a simples troca de fornecedores. Dentro de uma categoria de medicamentos, como antibióticos, os produtos não são necessariamente substituíveis. Porém, o Brasil não especificou quais produtos dentro da categoria medicamentos seriam prejudicados pela retaliação. Convém destacar que a categoria "medicamentos" inclui produtos como escovas e pastas de dentes. Vide WT/DS267/ARB/1, parágrafo 5.168; 5.180.

${ }^{376} \mathrm{O}$ Brasil não justificou a inclusão de toda a categoria de alimentos no seu pleito, tampouco segregou a classificação de produtos alimentícios em necessários e supérfluos. Os Estados Unidos destacaram que há produtos de luxo incluídos, como gomas de mascar sem açúcar. Vide WT/DS267/ARB/1, parágrafo 5.171.

$377 \mathrm{O}$ Brasil não identificou a parcela de bens importados destinada à polícia, militares e outros agentes do serviço público, embora o valor das importações no setor seja ínfimo. Vide WT/DS267/ARB/1, parágrafo 5.174 .

${ }^{378}$ WT/DS267/ARB/1, parágrafos 5.176-178.

${ }^{379}$ WT/DS267/ARB/1, parágrafos 5.187-189..

${ }^{380} \mathrm{WT}$ /DS267/ARB/1, parágrafos 5.190-195.
} 
O Brasil alegou também que o desequilíbrio entre as relações comerciais bilaterais torna impraticável e ineficaz a suspensão de concessões ou outras obrigações. Ademais, argumentou que a suspensão em bens não tem influência política suficiente para pressionar os Estados Unidos a não conceder subsídios ou a remover seus efeitos adversos e, portanto, não seria “eficaz” na indução de cumprimento da decisão da OMC.

Os árbitros compreendem que a parte reclamada que busca a retaliação não deve ser compelida a agir contra os seus próprios interesses ao aplicar tal suspensão. Todavia, entendem que o Brasil possui uma gama considerável de bens de consumo para retaliar. A “eficácia” está relacionada à capacidade de um membro recorrer a uma contramedida autorizada, que deverá induzir o cumprimento. Entretanto, a preferência de um membro por determinado tipo de contramedida, que seria mais poderosa em termos políticos, não é relevante para a análise dos árbitros. ${ }^{381}$

A conclusão dos árbitros não foi modificada pelo desequilíbrio significativo das relações bilaterais entre os países. O fato de que as exportações para o Brasil representam apenas uma pequena parcela das exportações dos Estados Unidos não significa necessariamente que as contramedidas aplicadas a alguns desses bens não será “eficaz” para fins de induzir o cumprimento. Caberá ao Brasil selecionar mercadorias em que a elevação de tarifas surtirá mais efeitos para induzir o cumprimento. Enfim, os árbitros entenderam que o valor das exportações dos Estados Unidos para o Brasil supera significativamente o valor autorizado de contramedidas e, portanto, o Brasil teria margem suficiente para definir os produtos específicos que integrariam a suspensão. ${ }^{382}$

À luz do exposto, os árbitros concluíram que não foi comprovada a existência dos requisitos da “impraticabilidade ou ineficácia” para o Brasil suspender concessões ou outras obrigações apenas no comércio de bens no nível de retaliação permitido de US\$ 294,7 milhões, calculado com base no ano fiscal de 2006 e com base nas importações brasileiras de bens de consumo em 2007. ${ }^{383}$ Todavia, os árbitros destacaram que o nível de contramedidas autorizado é variável. Ou seja, a aplicação da retaliação cruzada em propriedade intelectual dependerá de modelos econométricos, que possuem metodologias variadas e podem ter diferentes resultados.

Na hipótese do nível de contramedidas que o Brasil está autorizado aumentar para um nível que exceda esse valor, a suspensão de concessões ou outras obrigações

\footnotetext{
${ }^{381}$ WT/DS267/ARB/1, parágrafo 5.198.

${ }^{382}$ WT/DS267/ARB/1, parágrafo 5.199.

${ }^{383}$ WT/DS267/ARB/1, parágrafo 5.200.
} 
apenas no comércio de bens poderia não ser "praticável ou eficaz” nos termos do artigo 22.3(c) do ESC. Por esse motivo, os árbitros analisaram se "as circunstâncias são suficientemente graves” (subparágrafo “c” do artigo 22.3 do ESC) e também os requisitos do artigo 22.3(d) do ESC. ${ }^{384}$

\subsubsection{Circunstâncias suficientemente graves}

O requisito “circunstâncias suficientemente graves”, previsto no artigo 22.3(c) do ESC depende da análise do caso concreto. ${ }^{385}$ A verificação da gravidade das circunstâncias perpassa: (i) a análise dos elementos contidos no artigo 22.3(d) do ESC, qual seja, o comércio no setor em que houve a violação e sua importância para a parte reclamante (neste caso, o comércio em bens, incluindo algodão e outros produtos afetados pela medida em questão); e (ii) os elementos econômicos mais gerais relacionados com a anulação ou prejuízo e as consequências econômicas mais gerais da suspensão de concessões ou outras obrigações. Contudo, a análise não se limita a esses fatores, podendo incluir outros dependendo das “circunstâncias” específicas do caso. ${ }^{386}$

Nesse contexto, os árbitros concordaram com o Brasil que para verificar "as circunstâncias suficientemente graves”, deve-se averiguar o impacto sobre o Brasil decorrente da aplicação de contramedidas no comércio de bens (isto é, “as consequências econômicas mais gerais da suspensão de concessões ou outras obrigações”) e as circunstâncias mais gerais relacionadas à consideração da retaliação do Brasil em face do descumprimento, pelos Estados Unidos, das recomendações do OSC. ${ }^{387}$

O Brasil apontou diversos fatores para demonstrar que "as circunstâncias são suficientemente graves”, incluindo a concessão e manutenção dos subsídios proibidos; o aumento significativo das transações sustentadas pelo GSM 102 em 2009; a concessão contínua dos subsídios acionáveis e a promulgação da Farm Bill em 2008. Tais fatos atestam, de acordo com o Brasil, que os Estados Unidos não possuem a intenção de cumprir as recomendações do OSC. Outrossim, o Brasil destacou outro fator que comprova que "as circunstâncias são suficientemente graves": o potencial que as contramedidas em bens no Brasil poderiam acarretar sobre a economia e bem-estar da população. Os árbitros

\footnotetext{
${ }^{384}$ WT/DS267/ARB/1, parágrafos 5.201-202.

${ }^{385}$ WT/DS267/ARB/1, parágrafo 5.213.

${ }^{386}$ WT/DS267/ARB/1, parágrafo 5.215.

${ }^{387}$ WT/DS267/ARB/1, parágrafo 5.215.
} 
classificaram como razoáveis as considerações do Brasil acerca do requisito em questão (se “as circunstâncias são suficientemente graves”). ${ }^{388}$

Os árbitros afirmaram, contudo, que a mera concessão de subsídios não é suficiente para concluir que “as circunstâncias são suficientemente graves”. Porém, eles concordam com o Brasil que a estrutura específica dos subsídios em questão, mantidos durante muito tempo, criou uma vantagem competitiva artificial e duradoura para os produtores dos Estados Unidos sobre todos os outros, e, portanto, gerou uma distorção comercial expressiva, não somente no mercado americano, mas no mercado mundial. ${ }^{389}$

A despeito da concessão e manutenção de subsídios em questão, o Brasil permanece competitivo. Porém, isso não modifica o fato de que tais subsídios distorcem o comércio mundial de algodão e de outros produtos subsidiados. O valor autorizado de retaliação já demonstra que esses efeitos distorcivos não são insignificantes, mesmo para o Brasil. $^{390}$

Ademais, o Brasil destacou que a desproporção dos efeitos adversos referentes à retaliação em sua economia, se aplicado apenas ao comércio de bens, também contribui para a gravidade das circunstâncias. Os árbitros concordaram que esse aspecto é relevante. Assim, pelos elementos mencionados, os árbitros entenderam que "as circunstâncias são suficientemente graves”, nos termos do artigo 22.3(c) do ESC. ${ }^{391}$

\subsubsection{Requisitos do artigo 22.3(d)}

O artigo 22.3(d) do ESC prevê:

(d) ao aplicar os princípios acima, a parte deverá levar em consideração:

(i) o comércio no setor ou regido pelo acordo em que o grupo especial ou órgão de Apelação tenha constatado uma violação ou outra anulação ou prejuízo, e a importância que tal comércio tenha para a parte;

(ii) os elementos econômicos mais gerais relacionados com a anulação ou prejuízo e as consequências econômicas mais gerais da suspensão de concessões ou outras obrigações.

Os "elementos econômicos mais gerais relacionados com a anulação ou prejuízo" que devem ser considerados neste caso são aqueles relativos à anulação ou prejuízo para o Brasil provenientes dos subsídios em questão, enquanto as "consequências econômicas mais gerais da suspensão de concessões ou outras obrigações” podem incluir a

\footnotetext{
${ }^{388}$ WT/DS267/ARB/1, parágrafos 5.216-218.

${ }^{389}$ WT/DS267/ARB/1, parágrafo 5.219.

${ }^{390}$ WT/DS267/ARB/1, parágrafo 5.220.

${ }^{391}$ WT/DS267/ARB/1, parágrafos 5.221-222.
} 
análise das consequências econômicas da suspensão tanto para o Brasil quanto para os Estados Unidos. ${ }^{392}$

O argumento do Brasil de que não seria praticável ou eficaz suspender concessões ou outras obrigações apenas no comércio de bens está fundamentado principalmente na importância, para sua economia, do seu comércio bilateral com os Estados Unidos e nas possíveis consequências da retaliação proposta, que o Brasil considera que traria prejuízos para sua própria economia se aplicada somente em bens. Além disso, o Brasil demonstrou os impactos econômicos causados pelos subsídios em questão. Desse modo, os árbitros julgaram que o Brasil considerou os elementos constantes no artigo 22.3(d) do ESC. ${ }^{393}$

\subsubsection{Hipóteses em que poderá haver retaliação cruzada}

À luz do exposto, os árbitros determinaram que na hipótese do nível de contramedidas do Brasil superar determinado valor atualizado por meio de uma metodologia específica, o Brasil poderia suspender certas obrigações no TRIPS e/ou no GATS. Nos anos subsequentes em que o nível de retaliação ficar abaixo do valor citado, o Brasil terá autorização apenas para retaliar em bens. ${ }^{394}$

Portanto, em certos casos (dependendo do valor obtido com a aplicação da metodologia mencionada), talvez não seja praticável ou eficaz para o Brasil suspender concessões ou outras obrigações apenas no setor de bens. Neste caso, as circunstâncias seriam “suficientemente graves” nos termos do artigo 22.3 do ESC e o Brasil poderia retaliar no TRIPS ou no GATS. ${ }^{395} 396$ Tendo em vista a possibilidade de o Brasil utilizar a retaliação cruzada no TRIPS, os árbitros ressaltaram alguns aspectos de decisões anteriores, relativas aos casos EC - Bananas III e US - Gambling. ${ }^{397}$

Considerando que o nível e a forma das contramedidas podem variar de acordo com o período, os árbitros exigiram que o Brasil, se solicitar um pedido revisado de autorização para suspender concessões ou outras obrigações no OSC de acordo com esta decisão, seja o mais específico possível em termos de medidas a serem adotadas, em prol

\footnotetext{
392 WT/DS267/ARB/1, parágrafo 5.89.

${ }^{393}$ WT/DS267/ARB/1, parágrafos 5.226-229.

${ }^{394}$ WT/DS267/ARB/1, parágrafo 5.230.

395 WT/DS267/ARB/1, parágrafo 6.2.

${ }^{396} \mathrm{WT} / \mathrm{DS} 267 / \mathrm{ARB} / 1$, parágrafo 6.5.

${ }^{397}$ WT/DS267/ARB/1, parágrafo 5.233.
} 
da transparência e previsibilidade do processo. ${ }^{398}$ Aliás, o Brasil já tinha se comprometido a atualizar tais informações anualmente. ${ }^{399}$

Ademais, seguindo os precedentes da retaliação cruzada em propriedade intelectual, os árbitros destacaram a possibilidade de os Estados Unidos recorrerem ao OSC caso considere que o nível de contramedidas adotado pelo Brasil tenha excedido o valor “apropriado". 400

\subsubsection{Desdobramentos da disputa após a autorização da OMC para retaliar}

Diante da autorização, concedida em 2009, para o Brasil aplicar retaliação cruzada em propriedade intelectual no caso US -Cotton ${ }^{401}$, foi instituído, em outubro de 2009, por meio da Resolução CAMEX n 63/2009, um Grupo Técnico para “identificar, avaliar e formular propostas de implementação das contramedidas autorizadas, conforme decisões dos árbitros manifestadas nos documentos WT/DS267/ARB/1 e WT/DS267/ARB2 da $O M C^{\prime,}{ }^{402}$

O grupo é diversificado, composto por representantes do: (i) Ministério das Relações Exteriores - MRE (que também o coordena); (ii) da Secretaria Executiva da CAMEX; (iii) Ministério do Desenvolvimento Indústria e Comércio Exterior - MDIC; (iv) Casa Civil da Presidência da República; (v) Ministério da Fazenda - MF; (vi) Ministério da Agricultura, Pecuária e do Abastecimento - MAPA; (vii) Ministério do Desenvolvimento Agrário - MDA; (viii) Ministério do Planejamento, Orçamento e Gestão - MP; (ix) Ministério da Saúde; (x) Grupo Interministerial de Propriedade Intelectual - GIPI. ${ }^{403} \mathrm{O}$ envolvimento dos diversos órgãos governamentais e a permissão para convidar outros órgãos e entidades do setor público ou privado demonstram a preocupação brasileira de formular a melhor proposta de retaliação, caso seja necessário aplicá-la.

Mencionado grupo possui competência para:

\footnotetext{
${ }^{398}$ WT/DS267/ARB/1, parágrafo 5.234.

${ }^{399} \mathrm{WT} / \mathrm{DS} 267 / \mathrm{ARB} / 1$, parágrafo 5.235.

${ }^{400}$ WT/DS267/ARB/1, parágrafo 5.236.

$401267 . \quad$ Detalhes sobre a $\quad$ controvérsia disponíveis em <www.wto.org/english/tratop_e/dispu_e/cases_e/ds267_e.htm>. Acesso em 28/01/2012.

${ }^{401}$ Lei $n^{\circ} 12.270$, de 24 de junho de 2010, que dispõe sobre medidas de suspensão de concessões ou outras obrigações do País relativas aos direitos de propriedade intelectual e outros, em casos de descumprimento de obrigações do Acordo Constitutivo da Organização Mundial do Comércio.

${ }^{402}$ Art. $1^{\circ}$ da Resolução nº 63 da Câmara de Comércio Exterior - CAMEX de 28 de outubro de 2009.

403 Art. $2^{\circ}$ da Resolução n 63 da Câmara de Comércio Exterior - CAMEX de 28 de outubro de 2009.
} 
I - identificar, avaliar e propor medidas e instrumentos, inclusive legais, necessários à implementação das Decisões, bem como elaborar notas técnicas e avaliações de impacto destas medidas e instrumentos;

II - elaborar as listas de bens, serviços e direitos de propriedade intelectual, passíveis de sofrerem retaliação sob o amparo das Decisões;

III - submeter ao exame do Conselho de Ministros da CAMEX minuta de Resolução contendo as medidas, instrumentos, listas e parâmetros necessários para implementação das Decisões; e

IV - monitorar o cumprimento dos prazos estabelecidos pela CAMEX para a implementação, pelos órgãos e entidades da Administração Pública federal, das medidas e instrumentos relacionadas à implementação das Decisões. ${ }^{404}$

Consoante a competência descrita acima, o grupo preparou uma base legal (inicialmente sob a forma de medida provisória) que possibilitava a aplicação da retaliação cruzada em propriedade intelectual na OMC. Nesse contexto, nota-se que foi publicada, em fevereiro de 2010, a medida provisória $n^{\circ} 482$ de $2010^{405}$, que dispõe sobre medidas de suspensão de concessões ou outras obrigações do País relativas aos direitos de propriedade intelectual e outros, em casos de descumprimento de obrigações do Acordo Constitutivo da Organização Mundial do Comércio - OMC. ${ }^{406}$ Essa medida provisória, que foi convertida na lei $\mathrm{n}^{0} 12.270$ de 2010 , será detalhada no item a seguir.

Ademais, na esteira da transparência no âmbito interno, o governo brasileiro realizou consulta pública, concedendo oportunidade aos interessados de se manifestarem quanto à adoção da retaliação em determinados bens ${ }^{407}$. Com base nessa consulta, em março de 2010, o Brasil adotou uma lista de mercadorias objeto de suspensão de concessões assumidas em decorrência do GATT em relação aos Estados Unidos ${ }^{408}$. A Resolução n 15/2010 da CAMEX estabelecia a aplicação de direito adicional de até 100 pontos percentuais sobre a alíquota do imposto de importação de algumas mercadorias, como algodão e cosméticos, dentre diversos outros produtos, por 365 dias. A resolução, que entraria em vigor 30 dias após sua publicação, teve sua vigência postergada para abril de 2010 e, em seguida, 21 junho de 2010. ${ }^{409}$ Até o momento, ela não entrou em vigor, conforme se detalhará adiante.

\footnotetext{
${ }^{404}$ Art. $3^{\circ}$ da Resolução n 63 da Câmara de Comércio Exterior - CAMEX de 28 de outubro de 2009.

${ }^{405}$ Retificada em 12 de fevereiro de 2010 e convertida na Lei $n^{\circ} 12.270$ de 24 de junho de 2010.

${ }^{406}$ Antes da promulgação da medida provisória, já havia um projeto de lei no Congresso brasileiro sobre o tema. Trata-se do projeto de lei $\mathrm{n}^{\circ}$ 1.893/2007. Mais informações estão disponíveis em: $<$ www.camara.gov.br>. Acesso em 13/08/2013.

${ }^{407}$ Resolução n 74 da Câmara de Comércio Exterior - CAMEX de 06 de novembro de 2009.

${ }^{408}$ Resolução n 15 da Câmara de Comércio Exterior - CAMEX de 05 de março de 2010.

${ }^{409}$ Disponível em: <www.camex.gov.br>. Acesso em 13/08/2013.
} 
Em março de 2010, o Brasil realizou consulta pública sobre as medidas de suspensão de concessões ou obrigações relativas aos direitos de propriedade intelectual e outros, em relação aos Estados Unidos ${ }^{410}$. Tal medida, que seria adicional à retaliação em bens (como permitido pela OMC), almejava atingir requerentes, titulares ou licenciados de direitos de propriedade intelectual que fossem pessoas naturais nacionais dos Estados Unidos ou nele domiciliadas, ou ainda pessoas jurídicas domiciliadas ou com estabelecimento naquele país. Ademais, a consulta envolvia diversos aspectos da propriedade intelectual, como patentes de medicamentos, cultivares e direitos de autor sobre obras literárias e audiovisuais.

Logo após a consulta relativa à retaliação cruzada em propriedade intelectual, Brasil e Estados Unidos avançaram nas negociações. ${ }^{411}$ A situação culminou com a celebração entre as partes, em abril de 2010, de um Memorando de Entendimento sobre um fundo de assistência técnica e fortalecimento da capacitação relativo ao contencioso do algodão na OMC. ${ }^{412}$ Referido documento estabelece a obrigação assumida pelos Estados Unidos de depositar mensalmente US\$12,275 milhões ao fundo em questão, que é gerido pelo Instituto Brasileiro do Algodão (IBA). ${ }^{413}$ Os recursos destinam-se a compensar temporariamente o setor cotonicultor brasileiro.

Em 30 de abril de 2010, o Brasil notificou o OSC sobre a decisão de postergar a imposição de contramedidas mencionadas acima, já que as partes estavam negociando com o intuito de obter uma solução mutuamente satisfatória. O temor dos setores dos Estados Unidos que investem na área de propriedade intelectual gerou uma pressão no país para a celebração de um acordo com o Brasil.

Assim, em 17 de junho de 2010, a Câmara de Comércio Exterior - CAMEX suspendeu suas resoluções que mencionam retaliação em bens e propriedade intelectual. ${ }^{414}$ A decisão foi motivada pelo Acordo-Quadro para uma Solução Mutuamente Acordada para o Contencioso do Algodão na Organização Mundial do Comércio (WT/DS267)

\footnotetext{
${ }^{410}$ Resolução n 16 da Câmara de Comércio Exterior - CAMEX de 12 de março de 2010.

411 Disponível em: <www.itamaraty.gov.br/sala-de-imprensa/notas-a-imprensa/brasil-eua-contencioso-doalgodao-comunicado-mre-camex>. Acesso em 28/01/2012.

412 Disponível em: <www.itamaraty.gov.br/...algodao.../20-abr-2010-memorando-de-entendimento-brasileua-sobre-o-fundo-do-algodao-portugues $>$. Acesso em 28/01/2012.

${ }^{413}$ Mais informações sobre o IBA podem ser obtidas em <iba-br.com/estatuto.pdf>. Acesso em 25/11/2011. A composição do instituto foi publicada na Resolução n 50 da Câmara de Comércio Exterior - CAMEX de 27 de julho de 2010.

${ }^{414}$ Resolução n 43 da Câmara de Comércio Exterior - CAMEX de 17 de junho de 2010.
} 
(“Acordo-Quadro”). ${ }^{415} \mathrm{O}$ documento menciona a suspensão das contramedidas brasileiras autorizadas pela OMC, embora o país possa denunciar tal acordo a qualquer momento.

Tal acordo, que prevê consultas bilaterais periódicas, teve como escopo minimizar os efeitos dos subsídios dos Estados Unidos em relação aos produtores brasileiros de algodão, já que a lei agrícola norte-americana (Farm Bill) só poderia ser alterada a partir de 2012. Portanto, não corresponde à solução final da controvérsia. ${ }^{416} \mathrm{O}$ documento também reiterou a criação do fundo explicada acima, para os quais já foram feitos depósitos de mais de US\$ 480 milhões. ${ }^{417} 418$

A compensação financeira destinada ao Brasil não é a solução ideal, tendo em vista inúmeros questionamentos no sentido de que desta forma os Estados Unidos estariam também "subsidiando” 419 os cotonicultores brasileiros. Entretanto, como já mencionado, trata-se de um entendimento temporário, até a alteração da Farm Bill. Questiona-se se a alteração da legislação agrícola norte-americana obedecerá a decisão da OMC, assunto que será tratado no capítulo 4.

De qualquer forma, em 24 de junho de 2010 foi promulgada a Lei $n^{\circ} 12.270$, correspondente à conversão da medida provisória nº 482 de 2010, acerca da retaliação cruzada em propriedade intelectual. Como já mencionado neste capítulo, o Equador, por exemplo, reconhece normas internacionais como auto-executáveis ${ }^{420}$, o que facilitaria eventual implementação da retaliação cruzada em propriedade intelectual na disputa $E C$ Bananas III. O mesmo não ocorre com o Brasil, que precisou promulgar a lei mencionada. Diante disso, nota-se que o Brasil possui um arcabouço legal que permite a utilização desse mecanismo, em caso de descumprimento do Acordo-Quadro pelos Estados Unidos.

\footnotetext{
415 Publicado no Diário Oficial da União em 5 de agosto de 2010 e disponível em: <www.itamaraty.gov.br>. Acesso em 28/01/2012.

${ }^{416}$ Embora não conste no texto do acordo, a disputa ensejou o comprometimento dos Estados Unidos a reconhecer o status sanitário do estado de Santa Catarina como livre de febre aftosa sem vacinação, medida importante para as exportações brasileiras de carne bovina e suína. Até o momento, houve avanços na questão que, porém, não foi totalmente resolvida. Mais informações estão disponíveis em: O Estado de S. Paulo. Acordo Brasil-EUA em algodão pode ter impasse. 18 de abril de 2012. Disponível em: $<$ www.estadao.com.br/noticias/impresso,acordo-brasil-eua-em-algodao-pode-ter-impasse-,862426,0.htm>; e $<$ www.abipecs.org.br>. Acesso em 13/08/2013.

417 Valor Econômico. EUA tentam salvar acordo do algodão. 14 de março de 2013. Disponível em: <www.valor.com.br/empresas/3044676/eua-tentam-salvar-acordo-do-algodao\#ixzz2OAyaCVr5>. Acesso em 04/08/2013

418 Valor Econômico. EUA suspendem indenização do algodão. 08 de agosto de 2013. Disponível em: <www.valor.com.br/agro/3226034/eua-suspendem-indenizacao-do-algodao>. Acesso em 14/08/2013.

419 O termo aqui não é utilizado em sentido técnico, previsto na OMC. Trata-se de uma espécie de compensação concedida aos cotonicultores brasileiros.

${ }^{420}$ SUBRAMANIAN, Arvind; WATAL, Fayashree. Can TRIPS serve as an enforcement device for developing countries in the WTO? In: Journal of International Economic Law, p. 411.
} 
Mediante ameaça brasileira de adotar a retaliação cruzada, após a aprovação na Câmara dos Deputados dos Estados Unidos de uma norma que suspendia os pagamentos ao Instituto Brasileiro do Algodão (IBA), os Estados Unidos se comprometeram a continuar efetuando o pagamento mencionado ao Brasil, obrigação constante em novo acordo bilateral celebrado em 15 de julho de 2011. Nesse contexto, os representantes dos Estados Unidos reiteraram a necessidade de aguardar as negociações no Congresso sobre a política de subsídios agrícolas norte-americana, que deverá ser revista em $2013 .{ }^{421}$ O Brasil, por sua vez, reafirmou seu compromisso de não aplicar a retaliação permitida pela OMC.

Em junho de 2013, a Associação Brasileira de Produtores de Algodão (ABRAPA) anunciou a celebração de um acordo com a National Cotton Council (NCC), que representa os produtores de algodão dos Estados Unidos, com o intuito de encerrar o contencioso na OMC. De acordo com o entendimento, a ABRAPA aceitaria determinado nível de subsídios americanos na Farm Bill e, em troca, receberia uma compensação financeira de US\$ 220 milhões a ser paga em 18 parcelas após a aprovação da Farm Bill. ${ }^{422} \mathrm{O}$ governo brasileiro não se pronunciou oficialmente sobre o teor do acordo.

Em agosto de 2013, um representante do governo dos Estados Unidos anunciou na imprensa que os pagamentos feitos pelos Estados Unidos ao Brasil seriam suspensos a partir de outubro em decorrência do corte automático de recursos após o término da vigência da Farm Bill em setembro. O governo brasileiro aguarda a informação oficial para adotar providências. $^{423}$

Ante o exposto, nota-se que o contencioso do algodão é emblemático, já que o Brasil tem a possibilidade de aplicar a retaliação cruzada em propriedade intelectual, após promulgar lei sobre o tema e realizar consultas públicas. No entanto, o governo brasileiro demonstrou preferência pela solução mutuamente acordada, em detrimento da retaliação. ${ }^{424}$ Assim, por ora depreende-se que foi adotada a via negociada, tendo em vista a celebração do Acordo-Quadro. Resta saber se os compromissos serão cumpridos pelo país norte-americano. Caso os Estados Unidos descumpram sua parte do acordo, o Brasil está autorizado a aplicar a retaliação cruzada.

421 Acerca da prorrogação de vigência da Farm Bill para setembro de 2013, vide: $<$ www.brazilcouncil.org/sites/default/files/Farm\%20Bill\%20Extension\%20Jan\%2028\%202013.pdf>. Acesso em 14/08/2013.

${ }^{422}$ Valor Econômico. EUA suspendem indenização do algodão.

${ }^{423}$ Valor Econômico. EUA suspendem indenização do algodão..

${ }^{424}$ Disponível em: <iba-br.com/relatorio-de-gestao.pdf>. Acesso em 28/01/2012. 
Os aspectos que conduziram a negociação ocorrida até o momento serão analisados no capítulo 4. A seguir são apresentados aspectos da lei e da consulta pública realizada pelo Brasil sobre a suspensão de direitos de propriedade intelectual. Os elementos considerados pelo Brasil podem ser utilizados como modelo em futura retaliação cruzada em propriedade intelectual realizada por outros países.

\title{
3.4.5. Lei brasileira $n^{\circ} 12.270 / 2010$
}

Para usufruir o direito de retaliação em propriedade intelectual concedido ao Brasil no âmbito do contencioso US - Cotton, a exposição de motivos da medida provisória $\mathrm{n}^{\circ} 482$ de 2010 frisou a necessidade de criar uma lei que permitisse a suspensão de direitos de propriedade intelectual. Nesse sentido, asseverou:

\begin{abstract}
Para que seja legalmente possível aplicar retaliação em propriedade intelectual mediante suspensão, de forma discriminatória, de nossas obrigações internacionais na área, julga-se imprescindível a criação de nova norma específica. Isto porque, no ordenamento jurídico brasileiro, a propriedade intelectual encontra-se na esfera dos direitos de caráter privado e está consagrada em leis ordinárias específicas, conforme a área. Desse modo, a despeito de estarem plasmados no ordenamento jurídico internacional, os direitos de propriedade intelectual, enquanto direitos patrimoniais, estão alicerçados em dispositivos legais internos que protegem, em termos gerais, a propriedade e o direito adquirido. ${ }^{425}$
\end{abstract}

A lei brasileira, embora tenha sido promulgada no contexto do contencioso do algodão, não se restringe à disputa em questão ${ }^{426}$ e pode ser aplicada a qualquer retaliação no âmbito da propriedade intelectual, quando autorizada pela OMC. ${ }^{427}$ Portanto, em eventual disputa futura, as afirmações de que o Brasil irá retaliar terão mais credibilidade, já que isso será possível de acordo com a sua legislação doméstica.

Embora não se restrinja ao contencioso US - Cotton, a urgência da aprovação da medida provisória e posterior conversão na lei $n^{\circ} 12.270$ de $2010^{428}$ devia-se à busca de uma forma de conceder efetividade às medidas de retaliação autorizadas pelo OSC. Nesse contexto, a exposição de motivos da medida provisória $n^{\circ} 482$ de 2010 ressaltou que

\footnotetext{
${ }^{425}$ Disponível em: <www.planalto.gov.br/ccivil_03/_Ato2007-2010/2009/Exm/EMI-450-MRE-MF-MDIC09-Mpv-482-10.htm>. Acesso em 04/08/2013.

${ }_{426}$ Essa assertiva é corroborada pela exposição de motivos da medida provisória n 482 de 2010.

${ }^{427}$ Nesse sentido, dispõe seu artigo $1^{\circ}$ : "Esta Lei dispõe sobre medidas de suspensão de concessões ou outras obrigações do País relativas aos direitos de propriedade intelectual e outros, em casos de descumprimento de obrigações multilaterais por Membro da Organização Mundial do Comércio - OMC, quando a República Federativa do Brasil tenha sido autorizada pelo Órgão de Solução de Controvérsias da OMC a suspender a aplicação para o referido Membro de concessões ou outras obrigações sob os Acordos da OMC”.

${ }^{428}$ Neste item será tratada simplesmente como "lei”.
} 
“eventual retaliação em propriedade intelectual somente pode ser levada a cabo com adequada segurança jurídica se amparada pela correspondente previsão legal”. ${ }^{429}$

Esta lei se aplica aos seguintes direitos de propriedade intelectual ${ }^{430}$ : (a) obras literárias, artísticas e científicas; (b) artistas intérpretes ou executantes, produtores de fonogramas e organismos de radiodifusão; (c) programas de computador; (d) marcas; (e) indicações geográficas; (f) desenhos industriais; (g) patentes de invenção e de modelos de utilidade; (h) cultivares ou variedades vegetais; (i) topografias de circuitos integrados; (j) informações confidenciais ou não divulgadas; e (k) demais direitos de propriedade intelectual estabelecidos pela legislação brasileira vigente.

O rol de direitos de propriedade intelectual englobado na legislação em questão é muito abrangente. Isso é vantajoso em dois aspectos: primeiramente, o Brasil terá liberdade para escolher o tipo de retaliação que será mais benéfica ao interesse público e, simultaneamente, causará menos prejuízos ao Brasil. Em segundo lugar, isso aumenta o poder de barganha do Brasil em negociações sobre o tema, já que a legislação existente ameaça muitos setores do país que será retaliado. Desse modo, os setores ameaçados do outro país envolvido na disputa tendem a pressionar seu governo a cumprir a decisão da OMC, o que favorece o Brasil.

A considerável abrangência da lei brasileira não se esgota nos setores envolvidos. A diversidade de formas para aplicar as contramedidas é notável: (i) suspensão e limitação de direitos de propriedade intelectual; (ii) alteração de medidas para a aplicação de normas de proteção de direitos de propriedade intelectual; (iii) alteração de medidas para obtenção e manutenção de direitos de propriedade intelectual; (iv) bloqueio temporário de remessa de royalties ou remuneração relativa ao exercício de direitos de propriedade intelectual; e (v) aplicação de direitos de natureza comercial sobre a remuneração do titular de direitos de propriedade intelectual. Essas possibilidades serão detalhadas no item abaixo sobre a Resolução da CAMEX.

Em consonância com as decisões da OMC, segundo as quais a retaliação só pode repercutir sobre o país que violou as regras da organização, a lei brasileira prevê que:

Art. $5^{0}$ As medidas de que trata esta Lei somente poderão atingir requerentes, titulares ou licenciados de direitos de propriedade intelectual que sejam: I - pessoas naturais nacionais do Membro da OMC, na situação descrita no art. $1^{0}$, ou nele domiciliadas; ou

\footnotetext{
${ }^{429}$ Disponível em <www.planalto.gov.br/ccivil_03/_Ato2007-2010/2009/Exm/EMI-450-MRE-MF-MDIC09-Mpv-482-10.htm>. Acesso em 04/08/2013.

${ }^{430}$ Nos termos do seu artigo $2^{\circ}$.
} 
II - pessoas jurídicas domiciliadas ou com estabelecimento no Membro da OMC, na situação descrita no art. $1^{\underline{0}}$.

Ou seja, a regra abrange não somente os nacionais do retaliado, como também as pessoas (físicas ou jurídicas) que tenham domicílio ou estabelecimento no país retaliado.

Além disso, o artigo $6^{\circ}$ da lei prevê os modos de aplicação da retaliação em propriedade intelectual, os quais podem ser isolados ou cumulativos. Tais formas serão analisadas no item abaixo referente à consulta pública divulgada pela CAMEX e estão transcritas a seguir:

I - postergação do início da proteção a partir de data a ser definida pelo Poder Executivo, com a consequente redução do prazo de proteção, para pedidos em andamento de proteção de propriedade intelectual;

II - subtração do prazo de proteção, por prazo determinado, em qualquer momento de sua duração;

III - licenciamento ou uso público não comercial, sem autorização do titular;

IV - suspensão do direito exclusivo do titular de impedir a importação e comercialização no mercado interno de bens que incorporem direitos de patente, ainda que o bem importado não tenha sido colocado no mercado externo diretamente pelo titular dos direitos de propriedade intelectual ou com seu consentimento;

V - majoração ou instituição de adicional sobre os valores devidos aos órgãos ou entidades da administração pública para efetivação de registros de direitos de propriedade intelectual, inclusive para sua obtenção e manutenção;

VI - bloqueio temporário de remessas de royalties ou remuneração relativa ao exercício de direitos de propriedade intelectual dos licenciados nacionais ou autorizados no território nacional;

VII - aplicação de direitos de natureza comercial a serem deduzidos da remuneração a que fizer jus o titular de direitos de propriedade intelectual; ou VIII - criação de obrigatoriedade de registro para obtenção e manutenção de direitos de propriedade intelectual.

A lei estabeleceu também que a aplicação das medidas em questão será precedida de relatório preliminar da CAMEX, o qual conterá a minuta dessas medidas e a respectiva fundamentação. Será concedido prazo às partes interessadas para se manifestarem em relação ao referido relatório preliminar. Após o decurso desse prazo, o Conselho de Ministros da CAMEX decidirá acerca da retaliação em caráter final. ${ }^{431} 432$ Esse dispositivo encontra-se em consonância com o princípio da transparência da OMC, que também foi reiterado pelos árbitros da decisão US - Cotton. Ressalte-se que a previsibilidade é fundamental para os atores do setor privado que sofrerão as consequências de eventual suspensão de direitos de propriedade intelectual.

\footnotetext{
${ }^{431}$ A decisão terá caráter final, exceto se houver deliberação por aplicação de medida não contida no relatório preliminar. Nesta hipótese, deverá ser repetido o procedimento descrito no artigo $9^{\circ}$ da lei.

${ }^{432}$ Artigo $9^{\circ}$ da lei.
} 
O Brasil respeitou também outras condições impostas pela OMC. Uma delas corresponde ao caráter temporário da medida. Nesse contexto, o artigo 10 da lei prevê que:

Art. 10. As medidas de que trata esta Lei terão prazo determinado e somente poderão ser adotadas enquanto perdurar a autorização do Órgão de Solução de Controvérsias da OMC.

Parágrafo único. O restabelecimento, no âmbito da OMC, a qualquer tempo, de concessões ou de outras obrigações brasileiras suspensas:

I - não importa na restauração de direitos que tenham sido afetados pela aplicação das medidas; e

II - não prejudicará os interesses legítimos de terceiros decorrentes de contratos firmados ou de usos autorizados pelo Poder Executivo, durante a aplicação de medidas adotadas com fundamento nesta Lei.

O parágrafo único transcrito acima prevê que os direitos afetados pela retaliação não serão restaurados. Caso não ocorresse dessa forma, a retaliação seria menos eficaz, na medida em que os prejuízos decorrentes da suspensão de medidas poderiam ser restituídos aos titulares dos direitos. Isso mitigaria um dos efeitos da retaliação de induzir o cumprimento da decisão da OMC. Por outro lado, a exposição de motivos da medida provisória $n^{\circ} 482$ de 2010 destaca que a suspensão da retaliação não prejudicará os interesses legítimos de terceiros, nos termos do inciso II transcrito acima, como forma de preservar aqueles que investirem em determinado negócio amparados pelas medidas de retaliação. $^{433}$

Por fim, o artigo 11 da lei brasileira estipulou que "o Poder Executivo estabelecerá mecanismos para monitorar a aplicação das medidas adotadas com fundamento nesta Lei”. Julga-se correta a inserção deste dispositivo, pois a OMC salienta que a retaliação deve ser temporária, restrita ao país que violou a decisão da Organização e não pode ultrapassar o montante autorizado pelo OSC. Desse modo, a lei evidencia a preocupação do país em cumprir os requisitos estabelecidos pela OMC.

Em suma, observa-se a adequação da lei brasileira para a finalidade à que se destina. Primeiramente, porque restou clara a preocupação em obedecer aos ditames da OMC, respeitando as limitações legais da suspensão dos direitos de propriedade intelectual. Além disso, é abrangente e poderá ser utilizada em qualquer caso semelhante à controvérsia US - Cotton, o que poupa tempo, desgastes e incerteza no âmbito do Poder Legislativo, já que essa norma teve que tramitar pelo Congresso Nacional. O fato de englobar diversos tipos de direitos de propriedade intelectual indica que muitos setores

${ }^{433}$ Disponível em <www.planalto.gov.br/ccivil_03/_Ato2007-2010/2009/Exm/EMI-450-MRE-MF-MDIC09-Mpv-482-10.htm>. Acesso em 04/08/2013. 
seriam potencialmente afetados. Esse fato é importante para que os referidos setores pressionem seu país a cumprir a decisão da OMC, objetivo maior do Brasil com a promulgação desta lei. Vale lembrar que a lei brasileira foi elaborada por meio de um esforço conjunto entre diversos órgãos do governo brasileiro e especialistas no tema da propriedade intelectual, o que demonstra o engajamento do país em induzir o cumprimento da decisão proferida pelo OSC.

\subsubsection{Resolução CAMEX $n^{\circ} 16 / 2010$}

Seguindo o princípio da transparência da OMC, em março de $2010^{434}$, o Brasil realizou consulta pública sobre as medidas de suspensão de concessões ou obrigações relativas aos direitos de propriedade intelectual e outros, em relação aos Estados Unidos. ${ }^{435}$ Tal medida, que seria adicional à retaliação em bens (como estabelecido pela OMC), almejava "atingir requerentes, titulares ou licenciados de direitos de propriedade intelectual que sejam pessoas naturais nacionais dos Estados Unidos da América ou nele domiciliadas, ou ainda pessoas jurídicas domiciliadas ou com estabelecimento naquele país”. Desse modo, nota-se que o Brasil cumpre uma das exigências da aplicação da retaliação cruzada em propriedade intelectual de atingir apenas o país que violou regras da OMC. ${ }^{436}$

A consulta envolvia diversos aspectos da propriedade intelectual, como patentes de medicamentos, cultivares e direitos de autor sobre obras literárias e audiovisuais. O governo brasileiro apontou as possíveis medidas de retaliação cruzada em propriedade intelectual, constante no Anexo III da Resolução CAMEX n. 16/2010, a saber:

\begin{tabular}{|c|c|}
\hline NÚMERO & MEDIDA \\
\hline 01 & $\begin{array}{l}\text { Subtração, por tempo determinado, do prazo de proteção de direitos sobre patentes de } \\
\text { produtos ou processos relativos a medicamentos, inclusive veterinários. }\end{array}$ \\
\hline 02 & $\begin{array}{l}\text { Subtração, por tempo determinado, do prazo de proteção de direitos sobre patentes de } \\
\text { produtos ou processos relativos a produtos químicos agrícolas. }\end{array}$ \\
\hline 03 & $\begin{array}{l}\text { Subtração, por tempo determinado, do prazo de proteção de direitos sobre patentes de } \\
\text { produtos ou processos biotecnológicos agrícolas. }\end{array}$ \\
\hline 04 & Subtração, por tempo determinado, do prazo de proteção de direitos sobre cultivares. \\
\hline 05 & $\begin{array}{l}\text { Subtração, por tempo determinado, do prazo de proteção de direitos do autor e conexos } \\
\text { sobre modalidades de execução pública musical. }\end{array}$ \\
\hline 06 & $\begin{array}{l}\text { Licenciamento de patentes de produtos ou processos relativos a medicamentos, inclusive } \\
\text { veterinários, sem autorização do titular e sem remuneração. }\end{array}$ \\
\hline
\end{tabular}

434 Após o início do trâmite da medida provisória $n^{\circ} 482 / 2010$, posteriormente convertida na lei $n^{\circ}$ $12.270 / 2010$.

${ }^{435}$ Resolução n 16 da Câmara de Comércio Exterior - CAMEX de 12 de março de 2010.

${ }^{436}$ WT/DS27/ARB/ECU, parágrafo 147. 


\begin{tabular}{|c|c|}
\hline 07 & $\begin{array}{l}\text { Licenciamento de patentes de produtos ou processos relativos a produtos químicos } \\
\text { agrícolas, sem autorização do titular e sem remuneração. }\end{array}$ \\
\hline 08 & $\begin{array}{l}\text { Licenciamento de patentes de produtos ou processos biotecnológicos agrícolas, sem } \\
\text { autorização do titular e sem remuneração. }\end{array}$ \\
\hline 09 & $\begin{array}{l}\text { Licenciamento de direitos do autor e conexos sobre obras literárias, sem autorização do } \\
\text { titular e sem remuneração. }\end{array}$ \\
\hline 10 & $\begin{array}{l}\text { Licenciamento de direitos do autor e conexos para o exercício da comunicação ao } \\
\text { público de obras audiovisuais, sem autorização do titular e sem remuneração. }\end{array}$ \\
\hline 11 & $\begin{array}{l}\text { Suspensão do direito exclusivo do titular de impedir a importação e comercialização no } \\
\text { mercado interno de medicamentos, inclusive veterinários, que incorporem direitos de } \\
\text { patente, ainda que o bem importado não tenha sido colocado no mercado externo } \\
\text { diretamente pelo titular dos direitos de propriedade intelectual ou com seu } \\
\text { consentimento. }\end{array}$ \\
\hline 12 & $\begin{array}{l}\text { Suspensão do direito exclusivo do titular de impedir a importação e comercialização no } \\
\text { mercado interno de produtos químicos agrícolas que incorporem direitos de patente, } \\
\text { ainda que o bem importado não tenha sido colocado no mercado externo diretamente } \\
\text { pelo titular dos direitos de propriedade intelectual ou com seu consentimento. }\end{array}$ \\
\hline 13 & $\begin{array}{l}\text { Suspensão do direito exclusivo do titular de impedir a importação e comercialização no } \\
\text { mercado interno de produtos biotecnológicos agrícolas que incorporem direitos de } \\
\text { patente, ainda que o bem importado não tenha sido colocado no mercado externo } \\
\text { diretamente pelo titular dos direitos de propriedade intelectual ou com seu } \\
\text { consentimento. }\end{array}$ \\
\hline 14 & $\begin{array}{l}\text { Majoração ou instituição de adicional sobre os valores devidos ao Instituto Nacional da } \\
\text { Propriedade Industrial - INPI para efetivação de registros de direitos de propriedade } \\
\text { industrial, inclusive sua obtenção e manutenção. }\end{array}$ \\
\hline 15 & $\begin{array}{l}\text { Majoração ou instituição de adicional sobre os valores devidos ao Serviço Nacional de } \\
\text { Proteção de Cultivares - SNPC para efetivação de registros de direitos de propriedade } \\
\text { intelectual, inclusive sua obtenção e manutenção. }\end{array}$ \\
\hline 16 & $\begin{array}{l}\text { Majoração ou instituição de adicional sobre os valores devidos aos órgãos de registro de } \\
\text { direitos do autor e conexos para efetivação dos referidos registros. }\end{array}$ \\
\hline 17 & $\begin{array}{l}\text { Aplicação de direitos de natureza comercial sobre a remuneração a que fizer jus titular de } \\
\text { direitos de propriedade intelectual em matéria de patentes. }\end{array}$ \\
\hline 18 & $\begin{array}{l}\text { Aplicação de direitos de natureza comercial sobre a remuneração a que fizer jus titular de } \\
\text { direitos de propriedade intelectual em matéria de marcas. }\end{array}$ \\
\hline 19 & $\begin{array}{l}\text { Aplicação de direitos de natureza comercial sobre a remuneração a que fizer jus titular de } \\
\text { direitos de propriedade intelectual em matéria de direitos do autor e conexos, exceto os } \\
\text { relativos a programas de computador. }\end{array}$ \\
\hline 20 & $\begin{array}{l}\text { Aplicação de direitos de natureza comercial sobre a remuneração a que fizer jus titular de } \\
\text { direitos de propriedade intelectual em matéria de direitos do autor e conexos relativos a } \\
\text { programas de computador. }\end{array}$ \\
\hline 21 & $\begin{array}{l}\text { Criação de obrigatoriedade de registro para obtenção e manutenção de direitos } \\
\text { patrimoniais de autor e conexos. }\end{array}$ \\
\hline
\end{tabular}

As medidas 1 a 5 correspondem à subtração temporária do prazo de proteção de direitos sobre: (i) patentes de produtos ou processos relativos a medicamentos (inclusive veterinários), produtos químicos agrícolas e biotecnológicos agrícolas; (ii) cultivares; e (iii) autorais e conexos sobre modalidades de execução pública musical. Referida subtração 
poderá ocorrer em qualquer momento da duração do prazo de proteção desses direitos. ${ }^{437}$ Além disso, quando a medida cessar, não haverá restituição do prazo subtraído, nem prorrogação do prazo de proteção. ${ }^{438}$

Já as medidas 6 a 10 correspondem a licenciamento, sem autorização do titular e sem remuneração, de: (i) patentes de produtos ou processos relativos a medicamentos (inclusive veterinários), produtos químicos agrícolas e biotecnológicos agrícolas; (ii) direitos autorais e conexos sobre obras literárias e para o exercício da comunicação ao público de obras audiovisuais.

As hipóteses mencionadas acima diferem do licenciamento compulsório ${ }^{439}$, na medida em que não preveem remuneração ao requerente, titular ou licenciado desses direitos. $^{440}$ Ressalte-se que as medidas em questão foram autorizadas pela Lei n. $12.270 / 10$, nos termos do inciso III do artigo $6^{\circ 441}$, com a ressalva de que a referida lei (que não se refere apenas ao contencioso entre Brasil e Estados Unidos) deixa a possibilidade de remuneração à discricionariedade da Administração Pública. ${ }^{442}$

Os itens 11 a 13 preveem a suspensão do direito exclusivo do titular de impedir a importação e comercialização no mercado interno de medicamentos, produtos químicos e biotecnológicos agrícolas que incorporem direitos de patente, mesmo que o bem importado não tenha sido colocado no mercado externo diretamente pelo titular dos direitos de propriedade intelectual ou com seu consentimento. Destaca-se a tentativa de atingir o setor farmacêutico com essas medidas, que corresponde a um influente setor dos Estados Unidos capaz de manifestar-se perante o governo em prol do cumprimento da decisão da OMC.

As medidas 14 a 16 correspondem à majoração ou instituição de adicional para a efetivação de registros sobre os valores devidos: (i) ao INPI, relativos à propriedade industrial; (ii) ao Serviço Nacional de Proteção de Cultivares - SNPC, referentes a novas cultivares; e (iii) aos órgãos de registro nos casos de direitos do autor e conexos. Nos casos que envolvem o INPI e o SNPC é possível que sejam estabelecidos valores adicionais para

\footnotetext{
${ }^{437}$ Artigo $6^{\circ}$, inciso II da Lei $n^{\circ} 12.270 / 10$.

${ }^{438}$ Artigo 6 $6^{\circ} \S 1^{\circ}$ da Lei n 12.270/10 e Resolução CAMEX n 16/2010, Anexo III, parágrafo 4.

439 Previsto no artigo 31 do TRIPS.

${ }^{440}$ Resolução CAMEX n 16/2010, Anexo III, parágrafo 2.

${ }^{441}$ Art. $6^{\circ}$ "As medidas de que trata esta Lei poderão ser aplicadas isolada ou cumulativamente, na forma aprovada em resolução do Conselho de Ministros da Câmara de Comércio Exterior - CAMEX, nos seguintes modos:

(...)

III - licenciamento ou uso público não comercial, sem autorização do titular;

(...)"

${ }^{442}$ Artigo $6^{\circ}, \S 2^{\circ}$ No caso de que trata o inciso III do caput deste artigo, a medida poderá ser aplicada com ou sem remuneração.
} 
a consecução de outras atividades relativas aos referidos registros. ${ }^{443}$ Observa-se maior previsibilidade, nesta hipótese, em relação à duração e montante da medida, além de evitar riscos de prejuízo a terceiros.

No tocante aos direitos de natureza comercial sobre a remuneração que incidiriam sobre patentes, marcas, direitos do autor e conexos (itens 17 a 20), destaca-se que não são tributos. Desse modo, não são aplicáveis princípios do Direito Tributário, como o da anterioridade. ${ }^{444}$ Tais direitos assemelham-se a instrumentos de defesa comercial, como medidas antidumping.

A aplicação das medidas acima ocorrerá por meio de aplicação de percentual compensatório, por prazo determinado, conforme a Resolução da CAMEX que instituir a medida, e será devido na data do pagamento, da remessa ou do crédito ao titular dos direitos de propriedade intelectual, conforme disposto no art. $7^{\circ}$ da lei $n^{0} 12.270$ de 2010.445

Cabe destacar que os direitos de natureza comercial sobre a remuneração relativos a alguns direitos de propriedade intelectual permitem mensurar o tempo de retaliação, o valor e a nacionalidade atingida. Desse modo, encontra-se em consonância com as exigências das regras e decisões da OMC relativas à retaliação cruzada em propriedade intelectual.

Já a medida 21 corresponde à possibilidade de exigir registro para obtenção e manutenção de direitos patrimoniais de autor e conexos. A mudança inserida por este dispositivo corresponde à obrigatoriedade de registro relativa a direitos autorais e conexos, contrapondo-se ao cenário atual em que a proteção desses tipos de direitos de propriedade intelectual independe de registro, nos termos do artigo $18^{446}$ da lei n. 9.610/98.

Vale lembrar que a Resolução CAMEX não poderia alterar dispositivo previsto em lei. Desse modo, a lei n. 12.270/10, que autorizou a retaliação cruzada em propriedade

\footnotetext{
${ }^{443}$ Resolução CAMEX n 16/2010, Anexo III, parágrafo 4.

${ }^{444}$ Referido princípio encontra-se estabelecido nas alíneas "b” e “c”, do inciso III, artigo 150, da Constituição Federal, transcritas abaixo:

Art. 150. "Sem prejuízo de outras garantias asseguradas ao contribuinte, é vedado à União, aos Estados, ao Distrito Federal e aos Municípios: (...)

III - cobrar tributos:

(...)

b) no mesmo exercício financeiro em que haja sido publicada a lei que os instituiu ou aumentou;

c) antes de decorridos noventa dias da data em que haja sido publicada a lei que os instituiu ou aumentou, observado o disposto na alínea $b ;(. .)$.

${ }^{445}$ Resolução CAMEX n ${ }^{\circ}$ 16/2010, Anexo III, parágrafo 6.

${ }^{446}$ A lei nº 9.610/98 altera, atualiza e consolida a legislação sobre direitos autorais e dá outras providências. Prevê o seu artigo 18:

Artigo 18. “A proteção aos direitos de que trata esta Lei independe de registro”.
} 
intelectual prevê em seu artigo $6^{\circ}$, inciso VIII, “a criação de obrigatoriedade de registro para obtenção e manutenção de direitos de propriedade intelectual”. Já o §3 do mesmo artigo estabelece o momento em que isso deve ser realizado, a saber: "no caso da medida de que trata o inciso VIII deste artigo, o requerimento do registro será efetuado antes da distribuição, comercialização ou comunicação ao público das obras protegidas por direitos de autor e direitos conexos protegidos em território nacional”. Tendo em vista o princípio segundo o qual a lei posterior revoga a anterior ${ }^{447}$, resta reduzida a possibilidade de questionamento judicial nesta medida.

Observa-se que mais uma vez o governo brasileiro publicou regulamentação abrangente, de modo que o Poder Público teria discricionariedade para aplicar a medida da forma que julgasse mais eficaz.

${ }^{447}$ No Brasil, o princípio está previsto expressamente na Lei de Introdução às normas do Direito Brasileiro (Decreto-Lei $n^{\circ}$ 4.657/42):

Art. $2^{\circ}$ "Não se destinando à vigência temporária, a lei terá vigor até que outra a modifique ou revogue. $\S 1^{\circ} \mathrm{A}$ lei posterior revoga a anterior quando expressamente o declare, quando seja com ela incompatível ou quando regule inteiramente a matéria de que tratava a lei anterior. 


\section{RETALIAÇÃO VERSUS NEGOCIAÇÃO}

O presente capítulo almeja apresentar as principais dificuldades e benefícios da aplicação da retaliação cruzada em propriedade intelectual. Nesse contexto, são esboçadas implementações da mencionada retaliação em determinados setores de propriedade intelectual.

Ademais, são analisadas as circunstâncias que ensejam a negociação entre as partes envolvidas em uma disputa em que há autorização do OSC para aplicar a referida suspensão dos direitos de propriedade intelectual no âmbito do TRIPS. Para compreender essas negociações, é fundamental conhecer a teoria dos jogos de dois níveis, que trata da interação entre os setores público e privado de dois ou mais países. Essa teoria é aplicada ao contencioso do algodão (US - Cotton) ${ }^{448}$, com o intuito de explicar os resultados obtidos até o momento e perspectivas de solução da disputa.

\subsection{Dificuldades inerentes à retaliação cruzada em propriedade intelectual}

A retaliação cruzada em propriedade intelectual possui algumas dificuldades na sua aplicação. Determinadas limitações da retaliação cruzada ocorrem no âmbito da OMC, de suas regras ou decisões, como o montante da retaliação, seu caráter temporário e a nacionalidade do país retaliado. Há outros de natureza prática, pois podem dificultar a retaliação e, desse modo, impactar sobre as negociações. Esses dois tipos de dificuldades são analisados a seguir.

\subsubsection{Viabilidade econômica}

A viabilidade econômica remete à dependência do país retaliante em relação ao retaliado. Em certos casos em que houve autorização para suspender direitos de propriedade intelectual $^{449}$, havia a exigência de primeiramente retaliar em bens para, após certo montante, retaliar em propriedade intelectual. A retaliação em bens requer certos

\footnotetext{
448 O contencioso do algodão foi escolhido para aplicação da teoria dos jogos de dois níveis pelos seguintes motivos: (i) foi o único dos três precedentes que publicou uma lei sobre a retaliação cruzada em propriedade intelectual, contendo detalhes de eventual suspensão dos direitos previstos no TRIPS; e (ii) tendo em vista que o caso envolve o Brasil, foi possível realizar entrevistas com representantes do governo brasileiro e dos setor privado que participaram das negociações. Essas discussões foram fundamentais para compreender a dinâmica das negociações, já que há muitas informações estratégicas que não são públicas.

${ }^{449}$ EC - Bananas III e US - Cotton.
} 
cuidados, por exemplo: se os produtos escolhidos forem insumos para a indústria doméstica, haverá prejuízo à fabricação nacional; se forem bens de consumo, oneram o consumidor e pode repercutir sobre a inflação; a medida também pode prejudicar interesses privados relacionados a contratos celebrados por longo prazo. Ou seja, a decisão sobre a retaliação em bens teria que ser sopesada pelo governo, antes de cogitar a suspensão de direitos de propriedade intelectual.

A dependência econômica dos países é relevante na medida em que a suspensão de direitos (ainda que autorizada pela OMC) pode acarretar contrarretaliação em diferentes áreas. Por exemplo, o país em desenvolvimento que retalia pode ser excluído do Sistema Geral de Preferências (SGP) ${ }^{450}$, que corresponde a um mecanismo unilateral e não é recíproco. Portanto, quanto mais dependente o retaliante, maior será o prejuízo econômico e comercial da retaliação em comparação com os benefícios oriundos dessa suspensão.

A suspensão de direitos de propriedade intelectual também pode repercutir de forma negativa sobre os investimentos estrangeiros. Ainda que seja permitida pela OMC, do ponto de vista das empresas a incerteza sobre a forma de retaliação e a sua duração pode reduzir investimentos relativos à inovação no país retaliante.

Ademais, a suspensão de direitos de propriedade intelectual no âmbito de patentes, por exemplo, exige infraestrutura e capacitação do país retaliante. Isso geralmente é encontrado nos países emergentes, como o Brasil e a Índia, que possuem uma notável produção de medicamentos genéricos. Em outros países, como Antígua, é necessário recorrer à suspensão de direitos que exija menos infraestrutura, como a suspensão de direitos autorais. Assim, embora o acesso a medicamentos corresponda a um benefício social, a exploração de patentes farmacêuticas exige determinada capacidade de produção que nem todos os países conseguiriam alcançar em um breve período. ${ }^{451}$

O ônus da fiscalização do cumprimento dos critérios nos quais deve se pautar a retaliação cruzada não é desprezível. Aliás, essa questão pode representar inclusive custos financeiros, na medida em que pode exigir contratação de pessoas ou sistemas destinados à fiscalização das medidas.

\footnotetext{
450 O SGP concede privilégios aos países em desenvolvimento e de menor desenvolvimento relativo no acesso a mercados de determinados países desenvolvidos, em bases não recíprocas. Os benefícios em questão correspondem a uma redução na tarifa alfandegária. Autorizado pela OMC no âmbito da cláusula de habilitação, o SGP almeja propiciar o desenvolvimento dos países beneficiados. Mais informações disponíveis em <www.desenvolvimento.gov.br>. Acesso em 03/08/2013.

${ }^{451}$ WHITEMAN, Allison L., p. 207.
} 
Por esses motivos, a dificuldade econômica de aplicar a retaliação cruzada em propriedade intelectual é ainda maior para países em desenvolvimento de menor porte e os países de menor desenvolvimento relativo (PMDR). Deve-se, portanto, traçar uma estratégia específica para cada caso, considerando o país retaliante e o retaliado.

\subsubsection{Mercado consumidor}

O grau de eficácia da retaliação cruzada em propriedade intelectual depende de diversas circunstâncias, destacando-se a força política das indústrias afetadas no país retaliado e o montante da suspensão que o país está autorizado a implementar. ${ }^{452}$ Além disso, quanto maior o tamanho do mercado consumidor e a sua relevância para as indústrias instaladas no país que pode ser retaliado, maior o impacto de eventual retaliação em propriedade intelectual.

Tendo em vista que a suspensão de direitos de propriedade intelectual limita-se ao território do membro retaliante, as exportações para outros países onde os produtos ou serviços possuem proteção dos direitos de propriedade intelectual são ilegais, em princípio. Essa assertiva está de acordo com o princípio da territorialidade no Direito de Propriedade Intelectual, consoante o qual a proteção não resulta de acordos internacionais como o TRIPS, mas das leis nacionais que implementam esses acordos. Ressalte-se que esse princípio não coíbe exportações para países onde não há proteção dos direitos de propriedade intelectual em questão. Isso poderia aumentar o prejuízo aos titulares do país retaliado. ${ }^{453}$

Uma questão relacionada ao tema remete à teoria da exaustão dos direitos de propriedade intelectual para obter a importação paralela de bens produzidos sob a suspensão desses direitos no país retaliante. Isso permitiria que qualquer membro da OMC - que desejasse se beneficiar da suspensão do país retaliante - legalizasse a revenda, no seu próprio território de bens produzidos sob suspensão de direitos de propriedade intelectual no exterior. Desse modo, o impacto da retaliação cruzada seria ampliado e poderia haver benefícios à sociedade, por exemplo. ${ }^{454}$

\footnotetext{
452 SPADANO, Lucas Eduardo F. A., Cross-agreement retaliation in the WTO dispute settlement system: an important enforcement mechanism for developing countries? In: World Trade Review, v. 7, 2008, p 534.

${ }^{453}$ RUSE-KHAN, Henning Grosse. Suspending ip obligations under TRIPS: a viable alternative to enforce prevailing wto rulings?, p. 6.

${ }^{454}$ Idem, p. 7.
} 
Questiona-se se a exaustão internacional pode ser expandida para abranger não apenas bens vendidos com o consentimento do titular do direito de propriedade intelectual, mas também aqueles produzidos sob uma autorização da OMC de retaliação cruzada em propriedade intelectual. Essa prática provavelmente ensejaria pressão política contrária e uma disputa na OMC acerca da violação do TRIPS relacionada ao princípio da exaustão. De qualquer forma, nota-se que a ameaça de utilizar o princípio em questão pode aumentar o poder de barganha em eventual negociação com o país retaliado. ${ }^{455}$ Todavia, o uso deste mecanismo seria muito questionável, tendo em vista os direitos privados envolvidos e a interpretação ampla que estaria sendo concedida aos critérios para aplicar a retaliação cruzada em propriedade intelectual. Vale lembrar que os árbitros da disputa EC - Bananas III afirmaram que "distortions in third-country markets could be avoided if Ecuador would suspend the intellectual property rights in question only for the purposes of supply destined for the domestic market". 456

Outra opção para aumentar o impacto da retaliação cruzada em propriedade intelectual remete ao uso da internet. Como já mencionado no capítulo 3, Antígua considera esta ideia (especificamente, oferecer download online de trabalhos dos Estados Unidos protegidos por direitos autorais), com o intuito de ampliar o efeito da retaliação.

Em todas as opções mencionadas acima, deve-se ter em vista as decisões proferidas pela OMC relacionadas à retaliação cruzada em propriedade intelectual. Destacam-se, por exemplo, a necessidade de mensurar a retaliação, de que ela seja delimitada a certo território em face do país retaliado e que seja temporária. Alguns mecanismos sugeridos acima dificultam a fiscalização dos requisitos impostos pela OMC, como o uso da internet para retaliar. ${ }^{457}$ Para que os requisitos da aplicação sejam cumpridos, é necessário um efetivo controle da retaliação, o que pode exigir investimentos em sistemas de informática.

\subsubsection{Montante autorizado de suspensão dos direitos de propriedade intelectual}

O artigo 22.4 do TRIPS estabelece que "o grau da suspensão de concessões ou outras obrigações autorizado pelo OSC deverá ser equivalente ao grau de anulação ou

\footnotetext{
${ }^{455}$ RUSE-KHAN, Henning Grosse. Suspending ip obligations under TRIPS: a viable alternative to enforce prevailing wto rulings?, p. 7.

${ }_{456}$ WT/DS27/ARB/ECU, parágrafo 158.

${ }^{457}$ RUSE-KHAN, Henning Grosse. Suspending ip obligations under TRIPS: a viable alternative to enforce prevailing wto rulings?, p. 7.
} 
prejuízo.” Porém, mensurar o valor de uma retaliação em propriedade intelectual pode ser uma tarefa complexa. Primeiramente, porque o cálculo do direito à retaliação pode ser anual e em determinados casos, como o US - Cotton, pode variar a cada ano. Ou seja, a aplicação de determinada medida teria que observar o montante autorizado em certo período.

Esse é um dos motivos que embasam a exigência de transparência na aplicação da retaliação cruzada em propriedade intelectual, conforme ressaltado pelos árbitros na controvérsia US - Cotton. No caso em tela, cientes das variações de contramedidas conforme o período, os árbitros solicitam que o Brasil, nos pedidos de autorização para retaliar, fosse o mais específico possível acerca das medidas a serem adotadas, tendo em vista a transparência e a previsibilidade do processo. ${ }^{458}$

Além disso, o país retaliante deve controlar o valor retaliado, sob pena de ser contestado no OSC. Assim, na disputa EC - Bananas III, os árbitros sugeriram utilizar um sistema de licenciamento para a suspensão de concessões ou outras obrigações em propriedade intelectual. As licenças seriam concedidas para determinada pessoa por certo valor, quantidade e tempo. Adicionalmente, tais licenças poderiam ser revogadas pelo governo equatoriano a qualquer momento, o que facilita o controle do valor retaliado. ${ }^{459}$

Ressalte-se que a necessidade de controlar o montante retaliado exige um considerável esforço de fiscalização, o que requer maior engajamento do país retaliante e deve ser considerado ao analisar a viabilidade de aplicar a retaliação cruzada. O fato de os valores retaliados variarem conforme o período apenas agrava essa situação.

\subsubsection{Medida temporária}

O artigo 22.8 do ESC, transcrito abaixo, menciona o caráter temporário da suspensão dos direitos de propriedade intelectual:

\footnotetext{
A suspensão de concessões ou outras obrigações deverá ser temporária e vigorar até que a medida considerada incompatível com um acordo abrangido tenha sido suprimida, ou até que o Membro que deva implementar as recomendações e decisões forneça uma solução para a anulação ou prejuízo dos benefícios, ou até que uma solução mutuamente satisfatória seja encontrada. De acordo com o estabelecido no parágrafo 6 do Artigo 21, o OSC deverá manter sob supervisão a implementação das recomendações e decisões adotadas, incluindo os casos nos quais compensações foram efetuadas ou concessões ou outras obrigações tenham sido suspensas, mas não tenham sido aplicadas as recomendações de adaptar uma medida aos acordos abrangidos.
}

\footnotetext{
${ }^{458}$ WT/DS267/ARB/1, parágrafo 5.234.

${ }^{459}$ WT/DS27/ARB/ECU, parágrafo 161-165.
} 
Assim, se o país retaliado alterar sua medida para torná-la em conformidade com as regras da OMC ou se for celebrado um acordo entre as partes envolvidas na disputa, a retaliação cruzada em propriedade intelectual não poderá mais ser aplicada. Isso pode acarretar incerteza para as potenciais empresas que se beneficiariam da retaliação, evitando que elas se comprometam a realizar investimentos. Para usufruir de patentes farmacêuticas, por exemplo, geralmente é necessário realizar vultosos investimentos. Sem a segurança sobre o período da retaliação, as empresas podem ser desestimuladas a utilizar o mecanismo, pois assumiriam um risco maior.

Uma alternativa para mitigar eventuais danos para empresas no caso da suspensão de patentes seria selecionar produtos cujo período de proteção da patente está próximo de expirar. Assim, as empresas concorrentes poderiam ingressar no mercado rapidamente. ${ }^{460} 461$ No caso de países com a indústria de medicamentos genéricos desenvolvida, como Índia e Brasil, essa solução traria também benefícios sociais, por meio do acesso a medicamentos.

A retaliação em direitos autorais, por exemplo, exige menos investimentos para as empresas. Porém, o controle desse tipo de suspensão pode ser árduo para o governo do país retaliante, especialmente considerando a possibilidade de o conteúdo protegido por direitos autorais ser disseminado por meio da internet. Essa é uma das formas de retaliação que está em discussão na controvérsia US - Gambling. O governo de Antígua deverá, no caso de aplicar a retaliação, providenciar um mecanismo eficiente de fiscalização que possa ser suspenso a qualquer momento (quando for celebrado um acordo entre as partes na disputa, por exemplo).

Os ensinamentos da disputa EC - Bananas III são relevantes na análise deste aspecto, na medida em que a proposta de licença se coaduna com a temporariedade exigida, tendo em vista que essas licenças seriam concedidas para pessoas determinadas, por certo valor, quantidade e tempo.

Ante o exposto, a exigência de que a retaliação cruzada em propriedade intelectual seja uma medida temporária, consoante o artigo 22.8 do ESC, representa mais um desafio para o país retaliante, que deve investir recursos na fiscalização, sob risco de ser questionado no OSC.

\footnotetext{
${ }^{460}$ SPADANO, Lucas Eduardo F. A., Cross-agreement retaliation in the WTO dispute settlement system: an important enforcement mechanism for developing countries?, p 540.

${ }^{461}$ SUBRAMANIAN, Arvind; WATAL, Fayashree. Can TRIPS serve as an enforcement device for developing countries in the WTO? p. 413.
} 


\subsubsection{Nacionalidade do país retaliado}

A retaliação em propriedade intelectual deve atingir apenas nacionais do país retaliado. ${ }^{462}$ Tal requisito pode ser um desafio, na medida em que os titulares de direitos de propriedade intelectual de uma mesma empresa podem ter múltiplas nacionalidades. ${ }^{463}$

A lei brasileira $n^{\circ} 12.270 / 2010$, referente à retaliação em propriedade intelectual, aborda essa exigência da OMC em seu artigo 5², transcrito abaixo:

\footnotetext{
Art. $5^{\circ}$ As medidas de que trata esta Lei somente poderão atingir requerentes, titulares ou licenciados de direitos de propriedade intelectual que sejam:

I - pessoas naturais nacionais do Membro da OMC, na situação descrita no art. 1o, ou nele domiciliadas; ou

II - pessoas jurídicas domiciliadas ou com estabelecimento no Membro da OMC, na situação descrita no art. $1^{\circ}$.
}

Portanto, na implementação da medida é necessário criar um mecanismo capaz de realizar esse controle, para evitar que terceiros países sejam atingidos pela retaliação.

\subsubsection{Segurança jurídica e previsibilidade}

Este aspecto pode ser analisado em duas vertentes: sob a perspectiva daqueles que já realizaram investimentos em propriedade intelectual, notadamente em inovação; e sob o prisma daqueles que podem investir no cenário da retaliação cruzada em propriedade intelectual, utilizando benefícios deste mecanismo.

Em ambos os casos, a reduzida segurança jurídica pode diminuir investimentos, já que aumenta o risco. A necessidade de certeza jurídica para o setor privado perpassa diversos aspectos. Um deles remete à incerteza sobre duração da suspensão de propriedade intelectual, pois se o país retaliado cumprir a decisão da OMC ou celebrar um acordo com o membro retaliante, a suspensão de direitos não será mais cabível. O montante da retaliação, que é variável, também pode repercutir sobre investidores. Um terceiro ponto corresponde à possibilidade de questionamento judicial no âmbito doméstico, que poderia influenciar os efeitos de compromissos internacionais.

Uma forma de contornar a insuficiente previsibilidade e segurança para atores privados seria delegar as prerrogativas da suspensão de direitos para empresas estatais, que

\footnotetext{
${ }^{462}$ WT/DS27/ARB/ECU, parágrafo 155.

${ }^{463}$ SUBRAMANIAN, Arvind; WATAL, Fayashree. Can TRIPS serve as an enforcement device for developing countries in the WTO?, p. 414.
} 
não operam sob condições de mercado, ou concedendo garantias do Estado para investidores do setor privado. ${ }^{464}$ Nesta hipótese, seria necessário atentar-se à possibilidade de violação de outras regras multilaterais por parte do país retaliante, como o tratamento nacional. Além disso, num contexto de economia liberalizada, observa-se que o número de empresas estatais é reduzido, o que reduz a viabilidade da alternativa mencionada.

\subsubsection{Impactos da retaliação cruzada sobre direitos privados}

A suspensão das obrigações do TRIPS repercute sobre direitos privados de pessoas físicas ou jurídicas, ${ }^{465}$ já que os direitos de propriedade intelectual têm natureza privada. ${ }^{466}$ Tais pessoas não estão necessariamente envolvidas no descumprimento de certo país em relação às decisões e regras da OMC.

Os produtores de bens e fornecedores de serviço que são afetados por eventual retaliação no âmbito do GATT ou do GATS podem parar de exportar para o membro que impôs tal suspensão, mas o mesmo não ocorre com os titulares de direitos de propriedade intelectual. ${ }^{467}$ Logo, é maior o impacto da suspensão de direitos de propriedade intelectual sobre direitos privados quando comparada à retaliação em bens ou serviços.

Nesse sentido, no caso EC - Bananas III, os árbitros salientaram que a implementação da retaliação no TRIPS poderia ensejar conflitos com o ordenamento jurídico doméstico do membro que obteve autorização do OSC para retaliar e do membro afetado pela suspensão. ${ }^{468}$

\subsubsection{Compromissos internos e internacionais do retaliante}

Para que a retaliação cruzada seja aplicada, é necessário que o país retaliante respeite os acordos internacionais aos quais está obrigado, tanto os multilaterais como

\footnotetext{
${ }^{464}$ RUSE-KHAN, Henning Grosse. Suspending ip obligations under TRIPS: a viable alternative to enforce prevailing wto rulings?, p. 8.

465 SUBRAMANIAN, Arvind; WATAL, Fayashree. Can TRIPS serve as an enforcement device for developing countries in the WTO?, p. 408.

${ }^{466}$ Nesse sentido, o preâmbulo do TRIPS prevê: “(...) Reconhecendo que os direitos de propriedade intelectual são direitos privados; (...)".

${ }^{467}$ WT/DS27/ARB/ECU, parágrafo 159.

${ }^{468} \mathrm{WT} / \mathrm{DS} 27 / \mathrm{ARB} / \mathrm{ECU}$, parágrafo 160.
} 
bilaterais. ${ }^{469}$ Deve-se também respeitar seu ordenamento jurídico doméstico. Em ambos os casos, podem ocorrer questionamentos de natureza jurídica.

\subsubsection{Legislação interna}

A dificuldade de aplicar a retaliação cruzada em propriedade intelectual não ocorre apenas no âmbito dos tratados, como será abordado no próximo item, pois podem ser suscitadas questões relativas às legislações internas dos países. A existência de autorização na legislação doméstica é um dos fatores que aumenta a credibilidade da retaliação. Caso contrário, as medidas poderiam ser facilmente questionadas no Poder Judiciário.

Em alguns países, como no Equador, as normas internacionais são autoexecutáveis, facilitando eventual recurso à retaliação cruzada em propriedade intelectual. ${ }^{470}$ Em outros, é necessário ter autorização expressa, como no Brasil, onde foi promulgada a Lei $n^{\circ} 12.270$ de 2010, a qual dispõe sobre medidas de suspensão de concessões ou outras obrigações do país relativas aos direitos de propriedade intelectual e outros, em casos de descumprimento de obrigações do Acordo Constitutivo da OMC.

As dificuldades tornam-se maiores no âmbito doméstico quando há envolvimento de questões constitucionais, ${ }^{471}$ pois ainda que haja modificação infraconstitucional nos países, permanece a possibilidade de questionamento no âmbito judicial. No Brasil, o artigo $5^{\circ}$ da Constituição dispõe sobre propriedade intelectual, especificamente os incisos transcritos abaixo:

XXVII - aos autores pertence o direito exclusivo de utilização, publicação ou
reprodução de suas obras, transmissível aos herdeiros pelo tempo que a lei fixar;
XXVIII - são assegurados, nos termos da lei:
a) a proteção às participações individuais em obras coletivas e à reprodução da
imagem e voz humanas, inclusive nas atividades desportivas;
b) o direito de fiscalização do aproveitamento econômico das obras que criarem
ou de que participarem aos criadores, aos intérpretes e às respectivas
representações sindicais e associativas;
XXIX - a lei assegurará aos autores de inventos industriais privilégio temporário
para sua utilização, bem como proteção às criações industriais, à propriedade das

\footnotetext{
${ }^{469}$ RUSE-KHAN, Henning Grosse. Suspending ip obligations under TRIPS: a viable alternative to enforce prevailing wto rulings?, p. 8.

470 SUBRAMANIAN, Arvind; WATAL, Fayashree. Can TRIPS serve as an enforcement device for developing countries in the WTO?, p. 411.

${ }^{471}$ WHITEMAN, Allison L., Cross Retaliation Under the TRIPS Agreement: An Analysis of Policy Options for Brazil, p. 205.
} 
marcas, aos nomes de empresas e a outros signos distintivos, tendo em vista o interesse social e o desenvolvimento tecnológico e econômico do País;

Ante o exposto, observa-se que no Brasil os dispositivos constitucionais não abrangem todos os setores de propriedade intelectual passíveis de retaliação. Além disso, a Constituição não detalha a forma de proteção, omitindo, por exemplo, o prazo. Desse modo, embora haja risco de questionamentos judiciais, nota-se que existe margem para o governo brasileiro eventualmente aplicar a retaliação esquivando-se de violações à Constituição. Resta saber qual seria a interpretação dos magistrados.

Ademais, no tocante a outros países que tenham autorização para retaliar em propriedade intelectual, deve-se analisar o caso concreto, principalmente os aspectos constitucionais. A ameaça de retaliação será fortalecida com o respaldo da legislação doméstica e, assim, as negociações poderão ser impulsionadas. Caso contrário, o país retaliado saberá que terá grande probabilidade de reverter a suspensão de direitos na esfera judicial.

\subsubsection{Conflito com outros tratados}

A decisão da disputa $E C$ - Bananas III abordou a análise de eventual conflito com outros tratados relativos à propriedade intelectual. Nota-se que o artigo 2.2 do TRIPS, transcrito abaixo, pode suscitar dúvidas quanto à compatibilidade da retaliação em propriedade intelectual na OMC com os tratados administrados pela OMPI:

Nada nas Partes I a IV deste Acordo derrogará as obrigações existentes que os Membros possam ter entre si, em virtude da Convenção de Paris, da Convenção de Berna, da Convenção de Roma e do Tratado sobre a Propriedade Intelectual em Matéria de Circuitos Integrados.

O artigo 2.2 do TRIPS refere-se apenas às Partes I a IV deste acordo, enquanto os dispositivos acerca da “prevenção e solução de controvérsias” encontram-se na Parte V do TRIPS. Esta parte contém o artigo 64.1 $1^{472}$, consoante o qual o ESC aplica-se às disputas envolvendo o TRIPS, salvo disposição contrária específica ${ }^{473}$ no próprio acordo. Desse modo, não há disposição no TRIPS prevendo que o artigo 22 do ESC não se aplica ao TRIPS. $^{474}$ Portanto, os árbitros confirmaram a legalidade da retaliação cruzada em

\footnotetext{
${ }^{472}$ Artigo 64.1. "O disposto nos Artigos XXII e XXIII do GATT 1994, como elaborado e aplicado pelo Entendimento de Solução e Controvérsias, será aplicado a consultas e soluções de controvérsias no contexto desse Acordo, salvo disposição contrária especificamente prevista neste Acordo.”

${ }^{473}$ Como os artigos 64.2 e 64.3 do TRIPS.

${ }^{474}$ WT/DS27/ARB/ECU, parágrafo 152.
} 
propriedade intelectual na OMC e verificaram que o Equador estava em consonância com as normas multilaterais ao solicitar esta autorização ao OSC. ${ }^{475}$ Diversos autores corroboraram este entendimento. ${ }^{476}$

Além disso, como o OSC permite retaliação cruzada, o conflito aparente deve ser interpretado favoravelmente ao TRIPS, que é mais recente e específico. ${ }^{477}$ Essa assertiva encontra-se em conformidade com os artigos $30^{478}$ e $31^{479}$ da Convenção de Viena sobre o Direito dos Tratados de 1969. 480481

Tendo em vista que a referida Convenção de Viena não estabelece hierarquia entre as fontes de Direito Internacional, deve prevalecer a manifestação mais recente do Estado, que no caso em tela seria a autorização do OSC para suspender as obrigações do TRIPS. ${ }^{482}$

Ademais, as autorizações para suspender os direitos de propriedade intelectual no âmbito do TRIPS nem sempre se estendem para eventuais obrigações assumidas pelo país retaliante em outros acordos multilaterais de propriedade intelectual ou acordos bilaterais de livre comércio com o país retaliado. Tendo em vista que as obrigações em questão podem se sobrepor ou ir além do TRIPS, eventual suspensão deve ponderar o impacto e a legalidade desses outros acordos internacionais, considerando inclusive se os países envolvidos são signatários dos tratados em questão. ${ }^{483}$

\footnotetext{
$\overline{475}$ WT/DS27/ARB/ECU, parágrafo 153.

${ }^{476}$ Nesse sentido, vide: BASSO, Maristela; BEAS, Edson. Cross-retaliation through TRIPS in the Cotton Dispute? In: BRIDGES, v. 9, n. 5, 2005, p. 19; PAUWELYN, Joost. Conflicts of Norms in Public International Law: How WTO Law Relates to Other Rules of International Law. Cambridge: University Press, 2003, p. 346-347; SLATER, Gabriel L. The Suspension of Intellectual Property Obligations Under TRIPS: A Proposal for Retaliating Against Technology-Exporting Countries in the World Trade Organization. In: Georgetown Law Journal, v. 97, 2009, p. 1376-1377; AMARAL, Renata Vargas. Retaliação Cruzada na OMC: disciplina e desafios para o sistema multilateral de comércio. Tese de doutorado não publicada, Universidade Federal de Santa Catarina, 2012, p. 157.

${ }_{477}$ BASSO, Maristela; BEAS, Edson. Cross-retaliation through TRIPS in the Cotton Dispute?, p. 20.

${ }^{478}$ Artigo 30.2. 2. "Quando um tratado estipular que está subordinado a um tratado anterior ou posterior ou que não deve ser considerado incompatível com esse outro tratado, as disposições deste último prevalecerão".

${ }^{479}$ Artigo 31.3. 3. "Serão levados em consideração, juntamente com o contexto:

a) qualquer acordo posterior entre as partes relativo à interpretação do tratado ou à aplicação de suas disposições;

b) qualquer prática seguida posteriormente na aplicação do tratado, pela qual se estabeleça o acordo das partes relativo à sua interpretação;

c) quaisquer regras pertinentes de Direito Internacional aplicáveis às relações entre as partes."

${ }^{480}$ No Brasil, a Convenção mencionada foi internalizada por meio do Decreto n ${ }^{\circ} 7.030$ de 2009.

${ }^{481}$ Cumpre salientar que o artigo $5^{\circ}$ da referida Convenção prevê que "A presente Convenção aplica-se a todo tratado que seja o instrumento constitutivo de uma organização internacional e a todo tratado adotado no âmbito de uma organização internacional, sem prejuízo de quaisquer normas relevantes da organização." ${ }^{482}$ PAUWELYN, Joost. Conflicts of Norms in Public International Law: How WTO Law Relates to Other Rules of International Law, p. 346.

${ }^{483}$ RUSE-KHAN, Henning Grosse. Suspending ip obligations under TRIPS: a viable alternative to enforce prevailing wto rulings?, p. 5-6.
} 
Os árbitros da disputa EC - Bananas III destacaram que eles não tinham jurisdição, consoante o artigo 22.6 do ESC, para analisar se o Equador violaria tratados que não sejam da OMC (como de Paris, Berna e Convenção de Roma) ao aplicar a retaliação cruzada em propriedade intelectual. ${ }^{484}$

Em suma, embora prevaleça o entendimento de que a retaliação cruzada em propriedade intelectual não transgride acordos anteriores sobre o tema, não se descarta a possibilidade de violação ${ }^{485}$, dependendo da forma que a medida é aplicada e dos países envolvidos. Portanto, é um desafio que deve ser considerado no momento de eventual aplicação da retaliação.

\subsubsection{Acordos regionais}

A estagnação das negociações comerciais multilaterais, representadas pela Rodada Doha, estimularam diversos países a celebrarem acordos regionais. ${ }^{486} \mathrm{O}$ aumento do poder de países em desenvolvimento nas negociações contribui para o impasse com as nações desenvolvidas, em face do conflito de interesses, e, conseguintemente, dificulta a conclusão da Rodada. Assim, a celebração de acordos regionais emerge como um mecanismo de política comercial, culminando com acesso a mercado e redução de barreiras tarifárias, dentre outras consequências. O fenômeno não é exclusivo da propriedade intelectual: a OMC registra mais de 250 acordos regionais em vigor, englobando diversos temas. ${ }^{487}$

Na área de propriedade intelectual, além dos poucos avanços na mesa de negociações, a Declaração Ministerial de Doha sobre TRIPS e Saúde Pública de 2001 é outro motivo que justifica a busca de determinados países ${ }^{488}$ por acordos regionais. A busca por outros foros (“forum shifting”) pode elevar a proteção aos direitos de

\footnotetext{
${ }^{484}$ WT/DS27/ARB/ECU, parágrafo 154.

${ }^{485}$ Em uma entrevista um representante da OMPI sustentou que essa modalidade de retaliação pode infringir a Convenção de Berna. Vide: As Antigua considers cross-retaliation against us, WIPO official creates stir. In: BRIDGES Weekly Trade News Digest, v. 12, n. 2, de 23 de janeiro de 2008, disponível em: $<$ www.aoga.ag/docs/BridgesTradeNewsDigest_AntiguaConsidersCrossRetal_23Jan08.pdf.> Acesso em 28/01/2012.

${ }^{486}$ Vale lembrar que as próprias regras da OMC mencionam expressamente a possibilidade de celebração de acordos regionais ${ }^{486}$ no GATT (art. XXIV) e GATS (art. V), exceção ao princípio da nação mais favorecida. Ressalte-se que os países em desenvolvimento possuem também a prerrogativa de fundamentar acordos regionais por meio da cláusula de habilitação ("enabling clause").

${ }^{487}$ Disponível em <www.wto.org>. Acesso em 27/07/2013.

${ }^{488}$ Destacando-se os Estados Unidos, que teve contrariados os interesses da indústria farmacêutica no caso em tela.
} 
propriedade intelectual. ${ }^{489}$ Uma das justificativas remete à assimetria nas negociações bilaterais entre países desenvolvidos e em desenvolvimento. Nesses casos, o poder de barganha dos países em desenvolvimento diminui em comparação com o âmbito multilateral, em que há coalizões onde os países emergentes (com maior poder econômico, como Brasil e Índia) conseguem defender certos interesses de países em desenvolvimento de menor porte.

Essas obrigações assumidas no âmbito bilateral ou regional podem limitar o uso da retaliação cruzada. Tal assertiva deve ser compreendida considerando os acordos celebrados, sobretudo pelos Estados Unidos e União Europeia, em que há o aumento da proteção aos direitos de propriedade intelectual em comparação com as regras multilaterais da OMC. ${ }^{490}$ Essa elevação da proteção é conhecida como “TRIPS plus”, pois elimina algumas flexibilidades do TRIPS (como o licenciamento compulsório) e acrescenta proteção a temas não regulados no âmbito multilateral. Consequentemente, as possibilidades de utilização da retaliação cruzada em propriedade intelectual tornam-se restritas.

Tendo em vista que as três autorizações de retaliação em propriedade intelectual ocorreram em face da União Europeia e Estados Unidos, cabe apresentar uma breve análise da atuação desses membros da OMC na celebração de acordos regionais. No tocante à União Europeia, a indicação geográfica destaca-se como um tema prioritário, principalmente no que concerne a vinhos e destilados. Já os Estados Unidos regulam a propriedade intelectual em praticamente todos os seus acordos bilaterais, principalmente por meio de dispositivos "TRIPS plus". Observa-se nesses acordos norte-americanos o aumento à proteção de: patentes (como tema prioritário), marcas e direitos autorais e conexos, dentre outros aspectos. Ademais, há a inclusão de novos temas, como o domínio da internet. ${ }^{491}$ São diversos os exemplos da situação descrita. A seguir, serão apontados alguns casos para ilustrar o aumento da proteção dos direitos de propriedade intelectual por meio de acordos regionais.

Alguns exemplos são encontrados no setor farmacêutico. As medidas previstas em certos acordos regionais incluem: a extensão da proteção da patente por mais de 20

\footnotetext{
489 DRAHOS, Peter. Securing the future of intellectual property: Intellectual property owners and their nodally coordinated enforcement pyramid, p. 59-60.

490 RORIZ, João H. Ribeiro; TASQUETTO, Lucas da Silva. Propriedade intelectual, serviços e investimentos: panorama de regulação em acordos regionais de comércio celebrados por União Europeia, Estados Unidos, China e Índia. In: Texto para discussão do Instituto de Pesquisa Econômica, n. 1801, 2012, disponível em <www.ipea.gov.br/portal/images/stories/PDFs/TDs/td_1801.pdf>. $\quad \mathrm{O}$ texto detalha os setores de propriedade intelectual em que isso tem ocorrido.

${ }^{491}$ Idem, p. 10 a 24.
} 
anos; a proibição do uso de dados de teste sobre a eficácia e a segurança de medicamentos por certos períodos para a aprovação de produtos genéricos; e limitações à concessão de licenças compulsórias. Como consequência, a competição envolvendo medicamentos genéricos é limitada e pode haver redução de acesso a medicamentos. ${ }^{492}$

Nesse contexto, alguns acordos celebrados pelos Estados Unidos exigem que os países signatários aumentem o prazo de proteção das patentes (em relação ao TRIPS) para compensar atrasos: (i) nos procedimentos para a circulação dos medicamentos no mercado; e (ii) na análise dos pedidos de patentes. ${ }^{493}$

Ademais, o artigo 39.3 do TRIPS ${ }^{494}$ exige que os membros da OMC protejam dados reservados de testes de medicamentos e produtos químicos contra competição desleal. Não há, neste caso, obrigação de conceder direitos exclusivos relacionados a tais testes. Porém, alguns acordos firmados pelos Estados Unidos exigem a concessão de direitos exclusivos por pelo menos cinco anos da data de aprovação do produto, ainda que o produto não esteja patenteado e que a informação não seja reservada. ${ }^{495}$

Por fim, destaca-se o acordo celebrado entre Estados Unidos e Cingapura. Referido documento prevê que as partes podem excluir a patenteabilidade apenas nos casos previstos nos artigos $27.2^{496}$ e $27.3(\mathrm{a})^{497}$ do TRIPS. Ou seja, o artigo 27.3(b) ${ }^{498}$ do TRIPS foi eliminado. O acordo em questão também é mais restritivo em outros aspectos da propriedade intelectual, como licenças compulsórias e transferência de tecnologia. ${ }^{499}$ Para

492 CORREA, Carlos María. Implications of bilateral free trade agreements on access to medicines. In: Bulletin of the World Health Organization, v. 84, n. 5, 2006, p. 399.

${ }^{493}$ Idem, p. 400.

494 Artigo 39.3. "Os Membros que exijam a apresentação de resultados de testes ou outros dados não divulgados cuja elaboração envolva esforço considerável, como condição para aprovar a comercialização de produtos farmacêuticos ou de produtos agrícolas químicos que utilizem novas entidades químicas, protegerão esses dados contra seu uso comercial desleal. Ademais, os Membros adotarão providências para impedir que esses dados, sejam divulgados, exceto quando necessário para proteger o público ou quando tenham sido adotadas medidas para assegurar que os dados sejam protegidos contra o uso comercial desleal”.

495 CORREA, Carlos María. Implications of bilateral free trade agreements on access to medicines, p. 401.

${ }^{496}$ Artigo 27.2. "Os Membros podem considerar como não patenteáveis invenções cuja exploração em seu território seja necessário evitar para proteger a ordem pública ou a moralidade, inclusive para proteger a vida ou a saúde humana, animal ou vegetal ou para evitar sérios prejuízos ao meio ambiente, desde que esta determinação não seja feita apenas por que a exploração é proibida por sua legislação”.

${ }^{497}$ Artigo 27.3. "Os Membros também podem considerar como não patenteáveis:

a) métodos diagnósticos, terapêuticos e cirúrgicos para o tratamento de seres humanos ou de animais;”

498 Artigo 27.3. "Os Membros também podem considerar como não patenteáveis:

b) plantas e animais, exceto microorganismos e processos essencialmente biológicos para a produção de plantas ou animais, excetuando-se os processos não biológicos e microbiológicos. Não obstante, os Membros concederão proteção a variedades vegetais, seja por meio de patentes, seja por meio de um sistema 'sui generis' eficaz, seja por uma combinação de ambos. O disposto neste subparágrafo será revisto quatro anos após a entrada em vigor do Acordo Constitutivo da OMC.”

499 DRAHOS, Peter. Securing the future of intellectual property: Intellectual property owners and their nodally coordinated enforcement pyramid, p. 59-60. 
países exportadores de tecnologias como os Estados Unidos as licenças compulsórias representam uma grave ameaça, ${ }^{500}$ embora seja permitido pelo TRIPS (mediante o cumprimento de certos requisitos). ${ }^{501}$

\subsection{Possibilidades para a implementação da retaliação cruzada em propriedade intelectual}

Os direitos de propriedade intelectual podem acarretar custos sociais de curto prazo para diversos países, sobretudo pela necessidade de comprar bens e serviços essenciais, incluindo alimentos, medicamentos e componentes de novos projetos industriais de alta tecnologia. O ônus desses custos sociais, que pode variar entre os países, é reduzido em alguns casos devido ao aumento de investimento estrangeiro e a capacidade de empresas domésticas substituírem importações e aumentarem exportações por meio da inovação. ${ }^{502}$ Desse modo:

Cross-agreement retaliation (under TRIPS) curiously makes more economic
sense as a rebalancing mechanism than retaliation in goods. Contrary to the
latter, it can actually increase welfare in the country that retaliates (...), therefore
'compensating' for the loss of trade opportunities caused by the challenged
protectionist measure.

Superadas as dificuldades descritas no item anterior, a suspensão de direitos de propriedade intelectual pode ser utilizada em prol da sociedade, sobretudo no âmbito da saúde e da educação, por meio da ampliação do acesso a medicamentos ${ }^{504}$, a bens culturais, a produtos de entretenimento ou apenas a informações. ${ }^{505}$ Nesse sentido, constata-se que:

Ao contrário da propriedade física em geral, os direitos de propriedade
intelectual tendem a resultar na criação de informações socialmente úteis e
economicamente valiosas, o que torna a necessidade de difusão dessas
informações e de acesso pela coletividade, em especial consumidores e
concorrentes, uma questão de interesse público. Por outro lado, a exclusividade
conferida pelos direitos de propriedade intelectual restringe o acesso de terceiros
aos bens objeto de proteção, já que possibilita que sejam cobrados preços acima
do custo marginal como forma de retribuiçãa ao titular desses direitos. Esses
custos sociais podem ser ainda mais elevados quando as leis de propriedade
intelectual são excessivamente protecionistas em favor dos titulares de direitos

500 SLATER, Gabriel L. The Suspension of Intellectual Property Obligations Under TRIPS: A Proposal for Retaliating Against Technology-Exporting Countries in the World Trade Organization, p. 1365-1408.

501 CORREA, Carlos María. Implementing the TRIPS Agreement in the Patents Field: Options for Developing Countries, p. 93.

502 REICHMAN, Jerome; LANGE, David. Bargaining around the TRIPS agreement: the case for ongoing public-private initiatives to facilitate worldwide Intellectual Property transactions, p. 17-18.

503 SPADANO, Lucas Eduardo F. A., Cross-agreement retaliation in the WTO dispute settlement system: an important enforcement mechanism for developing countries?, p 521.

${ }^{504}$ Sobre o tema, vide DRAHOS, Peter. Four lessons for developing countries from the trade negotiation over access to medicines. In: Liverpool Law Review, v. 28, n 1, 2007, p. 11-39.

${ }^{505}$ BASSO, Maristela; BEAS, Edson. Cross-retaliation through TRIPS in the Cotton Dispute?, p. 20. 
exclusivos, desviando a finalidade social para a qual a proteção das criações intelectuais foi originalmente concebida, qual seja, estimular a inovação em benefício do desenvolvimento econômico e do progresso científico, tecnológico e cultural. ${ }^{506}$

No acesso a medicamentos, a referida retaliação pode aumentar a oferta de remédios patenteados, autorizando a produção de quantidade determinada para parcelas menos abastadas da população. Isso pode ser realizado por meio da licença compulsória, descrita nos artigos 30 e 31 do TRIPS, o que também contribuiria para a inovação. Ademais, pode facilitar a transferência de tecnologia, contribuindo para a inovação de um país. Vale lembrar que são objetivos da propriedade intelectual: o fomento ao progresso tecnológico e a divulgação do conhecimento disponível à sociedade, por meio do acesso público às inovações. ${ }^{507} \mathrm{Em}$ suma, a suspensão de alguns direitos do TRIPS pode beneficiar o desenvolvimento ${ }^{508}$ do país. ${ }^{509}$

É possível que a retaliação cruzada em propriedade intelectual seja aplicada nas partes II, III e IV do TRIPS. A parte II engloba: (i) direito do autor e direitos conexos; (ii) marcas; (iii) indicações geográficas; (iv) desenhos industriais; (v) patentes; (vi) topografias de circuitos integrados; (vii) proteção de informação confidencial; e (viii) controle de práticas de concorrência desleal em contratos de licenças. Já a parte III trata de aplicação de normas de proteção dos direitos de propriedade intelectual enquanto a parte IV aborda obtenção e manutenção de direitos de propriedade intelectual e procedimentos inter-partes conexos.

O presente trabalho explora algumas hipóteses de aplicação da retaliação cruzada em propriedade intelectual, especificamente seus efeitos sobre direitos autorais, patentes e marcas. Esses três setores de propriedade intelectual foram selecionados devido à atuação que tiveram (por meio do setor farmacêutico e das indústrias de entretenimento e direitos autorais) na elaboração do TRIPS, conforme apresentado no capítulo 2. Considerou-se também a influência dos setores em questão sobre o governo de países alvos

\footnotetext{
${ }^{506}$ LILLA, Paulo E. de Campos. Direitos de propriedade intelectual e o controle das práticas restritivas da concorrência à luz do acordo TRIPS/OMC. Tese de doutorado não publicada, Faculdade de Direito da Universidade de São Paulo, 2013, p. 34-35.

${ }^{507}$ ASSAFIM, João Marcelo de Lima. Controles sociais extrínsecos do exercício de direitos de propriedade intelectual: antitruste como tutela de direitos fundamentais. Disponível em: $<$ www.conpedi.org.br/manaus/arquivos/anais/campos/joao_marcelo_de_lima_assafim.pdf $>$, p. 12. Acesso em 10/08/2013.

${ }^{508}$ Os Estados devem se preocupar com políticas desenvolvimentistas, sobretudo quando houver necessidade de conciliar crescimento econômico com desigualdade social. Nesse sentido, vide: NASSER, Rabih Ali. A OMC e os Países em Desenvolvimento. São Paulo: Aduaneiras, 2002, p. 67.

${ }^{509}$ RUSE-KHAN, Henning Grosse. Suspending ip obligations under TRIPS: a viable alternative to enforce prevailing wto rulings?, p. 3.
} 
da suspensão de direitos de propriedade intelectual, ${ }^{510}$ sobretudo para os Estados Unidos, que ainda pode sofrer aplicação da retaliação cruzada em propriedade intelectual em dois casos (US - Gambling e US - Cotton). O objetivo desta parte é mostrar as vantagens e dificuldades dessas modalidades de suspensão dos direitos de propriedade intelectual.

\subsubsection{Direitos Autorais}

A proteção no campo de direitos autorais varia de acordo com institutos da Common Law ou Civil Law. A Common Law regula o direito autoral sob uma perspectiva econômica, enquanto a doutrina francesa adiciona aos aspectos econômicos o elemento moral, pautado nos direitos da personalidade. A doutrina francesa (droit d'auteur) influenciou a maior parte dos países de Civil Law, incluindo o Brasil. ${ }^{511}$ Em outras palavras: "Neste sistema do copyright, o direito moral só é reconhecido em certos limites, ou é negado. No sistema de civil law, ou nos países de tradição romano-germânica, o conceito de autoria é atribuído à pessoa física". 512

A posição norte-americana, da Common Law, prevaleceu na redação do TRIPS, consoante o artigo 9.1, excluindo a observância dos direitos morais dos autores. ${ }^{513}$ Vale lembrar que a retaliação cruzada na OMC em direitos autorais não poderá ultrapassar os limites previstos no TRIPS.

Além de proteger o autor, os direitos autorais também possuem uma vertente de interesses estatais. Nesse sentido:

\footnotetext{
Dans une approche intelectuelle: encourager la création c'est avoir une politique culturelle, facteur aussi bien de progrès que de divertissement. C'est aussi favoriser le rayonnement de son pays tant culturellement que politiquement. Dans uns approche matérielle : C’est défendre ou encorager un secteur important de l'économie nationale. On parle, par exemple, 'd’industrie cinématographique' ou de 'societé de l'information'. Et le droit d'auteur couvre aussi des créations utilitaires comme les logiciels ou les bases de données... ${ }^{514}$
}

Os Estados Unidos possuem uma notável indústria de entretenimento, conforme se depreende da influência dos filmes de Hollywood no mundo, corroborando o trecho acima que ressalta a proteção de um setor importante para a economia nacional. Isso

\footnotetext{
${ }^{510}$ ABBOTT, Frederick M. Cross-Retaliation in TRIPS: Options for Developing Countries. In: ICTSID Dispute Settlement and Legal Aspects of International Trade, n. 8, 2009, p. 37.

511 BARBOSA, Denis Borges; BARBOSA, Ana Beatriz Nunes. Direitos Autorais e TRIPS, 2005, p. 5. Disponível em: <denisbarbosa.addr.com/arquivos/200/propriedade/direitos_autorais.pdf>. Acesso em 28/01/2012.

512 BASSO, Maristela. O Direito Internacional da Propriedade Intelectual, p. 195.

513 Idem, p. 196.

${ }^{514}$ SIRINELLI, Pierre. Propriété littéraire et artistique, 2a ed. Paris: Dalloz, 2003, p. 5.
} 
poderia aumentar a pressão do setor privado sobre o governo norte-americano para o cumprimento da decisão da OMC no caso US - Cotton, favorável ao Brasil. Nesse sentido, nota-se que se a indústria de entretenimento tiver mais influência sobre o país retaliado do que o setor relacionado à violação das regras da OMC (ex: algodão e jogos de azar nos Estados Unidos e bananas na União Europeia), maior será a possibilidade de o país retaliado cumprir a decisão da OMC. ${ }^{515}$

Além disso, a aplicação da retaliação cruzada em direitos autorais pode ser benéfica ao retaliante, na medida em que permitirá o acesso a bens culturais e produtos de entretenimento. Exemplo disso remete a produtos como periódicos científicos, filmes, músicas e livros.

Em relação à forma de aplicação, observa-se que a suspensão de direitos de autor pode se delimitar a determinado tipo de direito autoral ou poderia também constituir uma limitação à distribuição de royalties, sem afetar o direito básico dos titulares de direitos autorais de não permitir o uso de seus trabalhos por terceiros. ${ }^{516}$

Os países precisam de pouca capacidade industrial para implementar a suspensão de direitos autorais, tendo em vista a facilidade de reproduzir produtos protegidos por tais direitos. Se o país retaliado cumprir a decisão da OMC, a suspensão deve deixar de ser aplicada. Neste caso, não haverá prejuízos consideráveis para o país retaliante, que não realizou vultosos investimentos para suspender direitos autorais. ${ }^{517}$

Em relação ao acesso a bens culturais, produtos de entretenimento e informações, uma notória dificuldade no âmbito da suspensão de direitos autorais corresponde à dificuldade de fiscalização. Tendo em vista que muitos trabalhos protegidos por direitos autorais, como músicas, estão disponíveis em formato digital, torna-se simples transferir o objeto para outra pessoa. Embora a suspensão de direitos autorais reduza a necessidade de infraestrutura, por outro lado aumenta a possibilidade de reprodução ilegal do material. Ou seja, a suspensão em direitos autorais exige que o país retaliante torne a fiscalização mais rigorosa. ${ }^{518}$

Essa afirmativa pode ser analisada por meio da situação relativa ao caso de Antígua em face dos Estados Unidos. No caso em questão, em Antígua, uma empresa

\footnotetext{
${ }^{515}$ WHITEMAN, Allison L., Cross Retaliation Under the TRIPS Agreement: An Analysis of Policy Options for Brazil, p. 214.

${ }^{516}$ ABBOTT, Frederick M. Cross-Retaliation in TRIPS: Options for Developing Countries. In: ICTSID Dispute Settlement and Legal Aspects of International Trade, p. 32.

${ }^{517}$ WHITEMAN, Allison L., Cross Retaliation Under the TRIPS Agreement: An Analysis of Policy Options for Brazil, p. 210.

${ }^{518}$ Idem, p. 207.
} 
denominada Zookz lançou um website oferecendo ilimitados downloads relativos a entretenimento por uma reduzida taxa mensal. Os operadores da empresa alegaram trabalhar sob a autorização da decisão da OMC. O governo de Antígua declarou que "os operadores de Zookz.com não atuaram na indústria de jogos do país, tampouco no caso que tramita na OMC" e que "Antígua não autorizou pessoas ou entidades a implementar a sanção". ${ }^{519}$ No momento, o site não está mais disponível. Esse exemplo ilustra os desafios que os governos podem enfrentar na fiscalização do uso de materiais protegidos por direitos autorais. ${ }^{520}$

Em decorrência da facilidade de reprodução e distribuição, a retaliação cruzada em direitos autorais corresponde a uma opção, conforme denota o artigo $4^{\circ}$, inciso I, alínea “a” da lei brasileira $\mathrm{n}^{\circ}$ 12.270/10. Todavia, o governo que retalia deve se atentar ao nível de reprodução, para manter o patamar de retaliação permitido pela OMC. ${ }^{521}$ Além disso, a retaliação deve ficar adstrita ao território do membro que retalia. Por tal motivo, é necessário controlar eventual retaliação que ocorra por meios digitais, para evitar que o conteúdo se dissemine mundialmente. ${ }^{522}$ Uma boa alternativa para contornar os empecilhos mencionados é utilizar o sistema de licenciamento ${ }^{523}$, já mencionado na análise do contencioso EC - Bananas III.

\subsubsection{Patentes}

São patenteáveis as invenções que cumpram três requisitos: novidade, inventividade e aplicação industrial ${ }^{524}$, não obstante algumas legislações nacionais tenham também outras exigências. ${ }^{525}$ Os mesmos requisitos encontram-se na lei brasileira, previstos no artigo $8^{\circ}$ da lei $n^{\circ} 9.279$ de 1996 . Sobre o conceito de patente, afirma-se que:

A patente é, para alguns, um direito, para outros, um título, outorgado pelo Estado, que confere ao seu titular o direito de impedir que terceiros explorem seu

\footnotetext{
${ }^{519}$ No original, em inglês: "[t] he operators of Zookz.com have not played any role in the Antiguan gaming industry or in our country's case pending before the WTO" and that "Antigua and Barbuda has not authorized any person or entity to implement sanctions." Disponível em: $<$ www.antiguawto.com/pr_zookz_antiguan_gov_jul09.pdf>. Acesso em 31/03/2013.

${ }^{520}$ WHITEMAN, Allison L., Cross Retaliation Under the TRIPS Agreement: An Analysis of Policy Options for Brazil, p. 207-208.

521 SLATER, Gabriel L. The Suspension of Intellectual Property Obligations Under TRIPS: A Proposal for Retaliating Against Technology-Exporting Countries in the World Trade Organization, p. 1396.

${ }^{522}$ ABBOTT, Frederick M. Cross-Retaliation in TRIPS: Options for Developing Countries, p. 33-34.

${ }^{523}$ WHITEMAN, Allison L., Cross Retaliation Under the TRIPS Agreement: An Analysis of Policy Options for Brazil, p. 210-211.

${ }^{524}$ Artigo 27.1 do TRIPS.

525 MATHÉLY, Paul. Le droit européen des brevets d'invention. Paris : Journal des notaires et des avocats, 1978, p. 97-98.
} 
objeto. Portanto, mais que um monopólio, ou um direito exclusivo de exploração, consiste num direito negativo conferido pelo Estado ao titular, compreendendo o próprio monopólio de exploração. Através de uma visão contratualista, em troca da divulgação do conhecimento relativo à invenção, em função de sua publicação, o Estado concede ao titular um direito triplamente limitado (quanto ao tempo, espaço e matéria), tendo em vista o interesse social e relevância para o desenvolvimento socioeconômico e tecnológico do País, no pressuposto de que é socialmente mais produtiva em tais condições a troca da exclusividade de fato (segredo da tecnologia), pela exclusividade de direito. ${ }^{526}$

A proteção por meio de patentes deve-se à tentativa de compensar o investimento realizado em pesquisa e desenvolvimento. Como tais custos são arcados antes do produto ingressar no mercado, uma ausência de proteção poderia acarretar vantagem competitiva a um concorrente, que não teria realizado investimentos em inovação. ${ }^{527}$ Embora o motivo econômico seja relevante, há também elevados custos sociais que devem ser considerados ${ }^{528}$, em decorrência de uma proteção por um período mínimo de 20 anos. Estudos demonstram que a introdução de regimes de proteção de patentes, pautado no TRIPS, em países de média e baixa renda gerou aumento de preços de venda, inclusive no caso de medicamentos. ${ }^{529}$

Uma das vantagens de suspender o direito de patentes é que o titular já divulgou a invenção de modo que terceiros pudessem reproduzi-la. Apesar disso, na prática é possível que haja informações técnicas adicionais importantes que não tenham sido divulgadas. ${ }^{530}$

Porém, a medida pode desestimular a inovação. No caso de medicamentos, por exemplo, os custos fixos de pesquisa e desenvolvimentos são altos e os custos marginais são muito reduzidos. No setor farmacêutico, a proteção temporal da patente leva médicos e pacientes a se acostumarem com a marca de um remédio (marcas reforçando patentes). Assim, quando a patente expira e medicamentos genéricos são introduzidos no mercado, as pessoas hesitam em substituir a marca conhecida por outra desconhecida, ainda que por um preço inferior e composição química semelhante. ${ }^{531}$

\footnotetext{
${ }^{526}$ GARCIA, Balmes Vega. Direito e tecnologia: regime jurídico da ciência, tecnologia e inovação. São Paulo: LTr, 2008, p. 147-148.

${ }^{527}$ LANDES, William M.; POSNER, Richard. The Economic Structure of Intellectual Property Law. Cambridge: Harvard University Press. 2003, p. 294.

${ }^{528}$ Idem, p. 310.

${ }^{529}$ POLIDO, Fabrício B. P.; CÉSAR, Priscilla M. D. G. Proteção patentária de medicamentos na interface com o direito à saúde: sustentabilidade do programa brasileiro de acesso universal às terapias antiretrovirais. In: BASSO, Maristela et al. Direitos de propriedade intelectual \& saúde pública : o acesso universal aos medicamentos anti-retrovirais no Brasil. São Paulo: IDCID, 2007, p. 76.

${ }_{530}$ ABBOTT, Frederick M. Cross-Retaliation in TRIPS: Options for Developing Countries, p. 25-26.

${ }^{531}$ LANDES, William M.; POSNER, Richard. The Economic Structure of Intellectual Property Law, p. 313314.
} 
Dentre outras opções, a retaliação por meio de patentes pode envolver: (i) suspensão de patentes ou de direito de prioridade aos nacionais do membro retaliado; (ii) reduzir ou eliminar alguns ou todos os direitos de patentes; e (iii) reduzir o prazo de proteção. ${ }^{532}$ Eventual suspensão dos direitos de patentes pode se aplicar horizontalmente às patentes do país retaliado ou pode ser restrita a determinadas categorias ou ainda a patentes específicas. $^{533}$

Devido ao caráter temporário da suspensão, o país que retalia deve estabelecer regras para a reintrodução da proteção de patentes, envolvendo questões como o direito de vender invenções remanescentes e isenção de responsabilidade em relação a eventuais alegações de infração durante o período da suspensão. ${ }^{534}$

No caso da suspensão relacionada a patentes, a vantagem para o país retaliado em relação a acesso a medicamentos exige capacidade produtiva aliada possivelmente à necessidade de realizar investimentos. Por tal motivo, provavelmente haveria menos empresas interessadas em utilizar esta modalidade em comparação com as empresas interessadas na suspensão de direitos autorais. Consequentemente, o menor número de empresas envolvidas simplificaria a fiscalização que deve ser realizada pelo governo do país retaliante, coibindo a reprodução ilegal. ${ }^{535}$

A suspensão dos direitos de propriedade intelectual em patentes farmacêuticas, por exemplo, pode beneficiar o desenvolvimento do mercado de genéricos. Todavia, o país precisa ter uma estrutura tecnológica e capacidade industrial que sejam suficientes para aproveitar tal benefício. ${ }^{536}$

Além disso, a medida prejudica importantes atores do setor privado, sobretudo da área farmacêutica. Vale lembrar que o setor privado exerce importante papel de induzir seu governo ao cumprimento de uma medida, por meio de pressão, sobretudo quando o mercado do país retaliante é importante para o seu negócio. Todavia, o uso desse mecanismo também pode desestimular investimentos no país retaliante, reduzindo recursos na área de pesquisa e desenvolvimento.

A lei brasileira $n^{\circ} 12.270 / 10$ permite expressamente que a retaliação cruzada em propriedade intelectual seja aplicada sobre patentes, por meio de seus dispositivos $4^{\circ}$,

532 SLATER, Gabriel L. The Suspension of Intellectual Property Obligations Under TRIPS: A Proposal for Retaliating Against Technology-Exporting Countries in the World Trade Organization, p. 1389.

${ }_{533}$ ABBOTT, Frederick M. Cross-Retaliation in TRIPS: Options for Developing Countries, p. 25.

${ }^{534}$ Idem, p. 26.

${ }^{535}$ WHITEMAN, Allison L., Cross Retaliation Under the TRIPS Agreement: An Analysis of Policy Options for Brazil, p. 218-219.

${ }^{536}$ RUSE-KHAN, Henning Grosse. Suspending ip obligations under TRIPS: a viable alternative to enforce prevailing wto rulings?, p. 8. 
inciso I, alínea “e”, e artigo 6º inciso IV. Desse modo, a aplicação da retaliação cruzada na área de patentes desponta como opção, na medida em que pode trazer benefícios sociais, como a licença compulsória ${ }^{537}$ de patentes farmacêuticas, que tende a ampliar o acesso a medicamentos. Vale lembrar que o Brasil já implementou o licenciamento compulsório no setor farmacêutico. ${ }^{538}$

\subsubsection{Marcas}

As marcas correspondem a sinais distintivos (nomes ou símbolos) que permitem que os clientes, consumidores ou usuários identifiquem determinados bens ou serviços. ${ }^{539}$ Esse direito de propriedade intelectual

Incorpora todas as características que o mercado atribui ao bem. Incorpora, portanto, a reputação do bem e é um poderoso veículo de transporte de preferências; tão poderoso que, por vezes, é capaz por si só de concentrar as preferências, constituindo um poderoso meio de criação de monopólios. ${ }^{540}$

Vislumbram-se algumas possibilidades de retaliação cruzada em marcas: (i) permitir que empresas domésticas usem marcas do país retaliado; (ii) suspender as penalidades para a violação dos direitos de propriedade intelectual relativos às marcas; (iii) proibir que nacionais do Estado retaliado registrem suas marcas no país retaliante. ${ }^{541}$

A retaliação cruzada em marcas não é aconselhável, pois prejudicará os consumidores do próprio país retaliante. ${ }^{542}$ Afinal, a marca também funciona como uma proteção ao consumidor, pois identifica a fonte e implicitamente suas qualidades e características. Nesse sentido: “a marca não é, portanto, um sinal de garantia de qualidade, senão na medida em que o empresário deseje manter o padrão de qualidade

\footnotetext{
${ }^{537}$ WHITEMAN, Allison L., Cross Retaliation Under the TRIPS Agreement: An Analysis of Policy Options for Brazil, p. 225.

538 Este caso não estava relacionado à retaliação cruzada, mas sim à permissão prevista no artigo 31 do TRIPS. Trata-se do caso envolvendo o medicamento Efavirenz, anti-retroviral comercializado no Brasil pela empresa Merck e ofertado ao Programa Nacional de DST-AIDS. O licenciamento compulsório em questão ocorreu por meio do Decreto $n^{\circ}$ 6.107/2007 e da Portaria $n^{\circ}$ 886/2007 do Ministro da Saúde, em que se declarou o interesse público sobre os direitos decorrentes das patentes relacionadas ao Efavirenz. Sobre o tema, vide: BASSO, Maristela et al. Direitos de propriedade intelectual \& saúde pública: o acesso universal aos medicamentos anti-retrovirais no Brasil. São Paulo: IDCID, 2007.

539 SILVEIRA, Newton. Propriedade intelectual: propriedade industrial, direito de autor, software, cultivares, nome empresarial, p. 21.

${ }^{540}$ FILHO, Calixto Salomão. Razoabilidade e legalidade do licenciamento compulsório do ponto de vista concorrencial. In: BASSO, Maristela et al. Direitos de propriedade intelectual \& saúde pública : o acesso universal aos medicamentos anti-retrovirais no Brasil. São Paulo: IDCID, 2007, p. 147-166.

${ }^{541}$ SLATER, Gabriel L. The Suspension of Intellectual Property Obligations Under TRIPS: A Proposal for Retaliating Against Technology-Exporting Countries in the World Trade Organization, p. 1388.

${ }^{542}$ Idem, p. 1388.
} 
dos produtos por ela assinalados, a fim de que não caiam em descrédito”. ${ }^{543}$ Assim, a retaliação em marcas pode prejudicar o consumidor, que talvez adquira produto ou serviço de qualidade inferior ao que pensa estar contratando. ${ }^{544}$

Por outro lado, considerando os elevados investimentos das empresas em publicidade de suas marcas, a retaliação cruzada nesse setor pode acarretar pressão do setor privado sobre o governo retaliado para que este cumpra a decisão da OMC.

A lei brasileira $n^{\circ}$ 12.270/10 possibilitou a aplicação de retaliação cruzada em marcas no artigo $4^{\circ}$, inciso I, alínea “b”. Todavia, os benefícios da sanção em marcas para o Brasil e outros eventuais retaliantes nessa modalidade são questionáveis, considerando o prejuízo aos consumidores domésticos.

\subsection{Negociações}

Conforme já apresentado no capítulo 2, o TRIPS é fruto das pressões exercidas pelas indústrias dos países desenvolvidos ${ }^{545}$, o que denota a importância da propriedade intelectual para as economias desses países. ${ }^{546}$

A mera ameaça de retaliação cruzada em propriedade intelectual pode levar setores influentes a pressionar o governo ao cumprimento das normas da OMC. ${ }^{547} \mathrm{Em}$ outras palavras: "the very presence of the threat of such retaliatory action in domestic intellectual property legislation could lead to improved compliance by developed countries". ${ }^{548}$ Destaca-se o papel das indústrias afetadas por eventual suspensão dos direitos de propriedade intelectual:

\footnotetext{
Affected industries are likely to lobby their respective (non-complying) governments to do everything necessary to avoid such suspensions in the first place and, if already in place, to act as soon as possible to remove them. Imagine the potential impact on Microsoft, Pfizer or Nike if Brazil was to suspend
}

\footnotetext{
543 SILVEIRA, Newton. Propriedade intelectual: propriedade industrial, direito de autor, software, cultivares, nome empresarial, p. 22.

${ }^{544}$ ABBOTT, Frederick M. Cross-Retaliation in TRIPS: Options for Developing Countries, p. 27.

${ }^{545}$ BASSO, Maristela. O Direito Internacional da Propriedade Intelectual, p. 164.

${ }^{546}$ BARTON, John H. The future of the intellectual property system and consequent negotiation topics. In: Views on the Future of the Intellectual Property System. Geneva: International Centre for Trade and Sustainable Development, 2007, p. 14.

547 SUBRAMANIAN, Arvind; WATAL, Fayashree. Can TRIPS serve as an enforcement device for developing countries in the WTO?, p. 406-407. Em sentido contrário vide TOWNSEND, David J. Stretching the dispute settlement understanding: U.S. - Cotton's relaxed interpretation of cross-retaliation in the World Trade Organization, p. 135-165 (afirmando que a ameaça de retaliação cruzada não mudou o posicionamento dos Estados Unidos na disputa US - Cotton).

548 SUBRAMANIAN, Arvind; WATAL, Fayashree. Can TRIPS serve as an enforcement device for developing countries in the WTO?, p. 403.
} 
copyright protection for software, patent protection for pharmaceuticals, or trademark protection for certain brand names and logos in order to pressure the US to implement the WTO rulings in US - Cotton. Therefore, while its effectiveness depends on further aspects of economic feasibility discussed below, suspending obligations under TRIPS generally provides a much stronger incentive to industrialized countries to comply with WTO rulings than traditional forms of retaliation. ${ }^{549}$

Este item explora a dinâmica das negociações entre os setores público e privado na esfera internacional sob o prisma da teoria dos jogos de dois níveis. Essa teoria é essencial para compreender os precedentes em que foi autorizada a aplicação da retaliação cruzada em propriedade intelectual, já que os países em desenvolvimento utilizaram a seu favor a importância da propriedade intelectual nos países desenvolvidos.

\subsubsection{Teoria dos jogos de dois níveis: interação entre setores público e privado}

Diversas teorias internacionais consideram Estados como atores unitários respondendo a estímulos externos. ${ }^{550}$ Porém, essas teorias nem sempre explicam os resultados das negociações internacionais, ${ }^{551}$ as quais não tratam apenas de relações entre Estados, pois também envolvem custos e benefícios entre grupos domésticos. ${ }^{552}$

As teorias que observam Estados como entidades unitárias desconsideram as ações que envolvem atores internos dos países, como o setor privado e organizações não governamentais. Ao fazê-lo, ignoram elementos importantes das negociações internacionais, especialmente no âmbito do comércio internacional, em que a influência desses atores é essencial para compreender determinadas ações governamentais.

A ameaça da retaliação cruzada em propriedade intelectual geralmente envolve a pressão dos setores ameaçados sobre o governo de seu país em prol da alteração da medida que violou regras da OMC. Na disputa US - Cotton, certos setores industriais (como farmacêutico e de entretenimento) pressionaram o governo norte-americano para

\footnotetext{
${ }^{549}$ RUSE-KHAN, Henning Grosse. Suspending ip obligations under TRIPS: a viable alternative to enforce prevailing wto rulings?, p. 2-3.

${ }_{550}$ MORAVCSIK, Andrew. Introduction: Integrating International and Domestic Theories of International Bargaining. In: EVANS, Peter B.; JACOBSON, Harold K.; PUTNAM, Robert D. Double-edged diplomacy: international bargaining and domestic politics, $2^{\mathrm{a}}$ ed. Berkeley: University of California Press, 1993, p. 5.

551 ODELL, John S. International Threats and Internal Politics: Brazil, European Community, and the United States. In: EVANS, Peter B.; JACOBSON, Harold K.; PUTNAM, Robert D. Double-edged diplomacy: international bargaining and domestic politics, $2^{\mathrm{a}}$ ed. Berkeley: University of California Press, 1993, p. 236.

${ }^{552}$ EVANS, Peter B. Building an Integrative Approach to International and Domestic Politics: Reflections and Projections. In: EVANS, Peter B.; JACOBSON, Harold K.; PUTNAM, Robert D. Double-edged diplomacy: international bargaining and domestic politics, $2^{\mathrm{a}}$ ed. Berkeley: University of California Press, 1993, p. 397.
} 
retirar os subsídios ao algodão. Esse era um dos objetivos do governo brasileiro quando pediu autorização ao OSC para suspender os direitos de propriedade intelectual: usar certos setores domésticos dos Estados Unidos para tentar obter a vitória real (e não apenas na OMC) do caso, qual seja, a retirada dos subsídios agrícolas.

A teoria dos jogos de dois níveis presume que os governantes tentam, simultaneamente, manipular a política doméstica e internacional. O resultado das negociações internacionais depende da estratégia dos governantes de influenciar a política doméstica no seu país. Ao controlar as informações e recursos no tocante à sua política doméstica, os representantes do governo podem abrir novas possibilidades para acordos internacionais. Esses representantes também podem atingir grupos domésticos em terceiros países, obtendo aliados. ${ }^{553}$

De acordo com a teoria dos jogos de dois níveis de R. Putnam, é possível classificar o processo de negociação em duas etapas ${ }^{554}$ :

(i) Nível I: corresponde à barganha entre os negociadores que acarreta uma tentativa de acordo (âmbito internacional).

(ii) Nível II: remete às discussões dos grupos domésticos relativos à ratificação $^{555}$ (ou não) do acordo. Tal estágio pode ser composto, por exemplo, por grupos de interesse, classes sociais e “opinião pública”.

As etapas doméstica e internacional são simultâneas, já que as expectativas e desdobramentos em uma das arenas influenciam as negociações na outra esfera. ${ }^{556}$ Podem ocorrer, por exemplo, consultas prévias e negociações no nível II com o intuito de formular uma posição para a negociação do nível I. ${ }^{557}$ A exigência de respaldo do nível II também repercute sobre o nível I. ${ }^{558}$

Portanto, é nítida a interação entre os níveis, fator que ocorre na prática em muitas negociações internacionais, inclusive as relacionadas à retaliação cruzada em propriedade intelectual.

\footnotetext{
553 MORAVCSIK, Andrew. Introduction: Integrating International and Domestic Theories of International Bargaining, p. 15.

${ }^{554}$ PUTNAM, Robert D. Diplomacy and Domestic Politics: The Logic of Two-Level Games. In: International Organization, v. 42, n. 3, 1988, p. 436.

555 A ratificação, neste caso, significa apoio. Nesse sentido, vide: MORAVCSIK, Andrew. Introduction: Integrating International and Domestic Theories of International Bargaining, p. 20.

${ }^{556}$ MORAVCSIK, Andrew. Introduction: Integrating International and Domestic Theories of International Bargaining, p. 23.

${ }^{557}$ No contencioso US - Cotton, isso pode ser observado na realização de duas consultas públicas, uma relativa à retaliação em bens e outra em propriedade intelectual.

${ }^{558}$ PUTNAM, Robert D. Diplomacy and Domestic Politics: The Logic of Two-Level Games, p. 436.
} 
No nível nacional, grupos domésticos lutam pelos seus interesses pressionando o governo a adotar políticas favoráveis, enquanto os políticos buscam poder construindo coalizões com tais grupos. Já no nível internacional, os governos tentam otimizar sua capacidade de lidar com pressões domésticas, enquanto minimizam as consequências adversas das evoluções externas. Nenhum dos dois jogos pode ser ignorado pelos tomadores de decisão, já que seus países, embora sejam soberanos, são interdependentes. $^{559}$ Assim, as estratégias buscadas no âmbito doméstico pelos negociadores podem ser importantes para a ratificação de um acordo internacional. ${ }^{560}$

\subsubsection{Win-set}

Um conceito importante na teoria dos jogos de dois níveis corresponde ao “conjunto de vitórias” (win-set), o qual significa todos os acordos possíveis do nível I que teriam apoio do nível II. Quanto maior o win-set, maior a probabilidade de ocorrerem acordos no nível I. Logo, quanto menor o win-set, maior a chance de fracasso. ${ }^{561}$

Uma ratificação fracassada pode ser classificada de dois modos: voluntária e involuntária. A involuntária denota a impossibilidade de o negociador cumprir sua obrigação internacional diante da ausência de apoio do nível II. A voluntária ocorre quando o próprio negociador não quer cumprir o acordo. ${ }^{562} \mathrm{Na}$ prática, todavia, nem sempre é simples identificar se o insucesso foi voluntário ou não. De qualquer modo, salienta-se que a forma involuntária somente pode ser compreendida na estrutura dos jogos de dois níveis, pois demonstra a existência de dois posicionamentos dentro de um mesmo país.

Se as partes do nível I (que geralmente representam os Estados) identificarem um considerável win-set, determinado negociador tende a ser mais pressionado pelos demais negociadores. Por outro lado, um conjunto de vitórias mais restrito pode corresponder a um maior poder de barganha na negociação, na medida em que o negociador evidencia a dificuldade que terá para ratificar o acordo e, assim, pode tentar torná-lo mais favorável ao seu posicionamento. Por isso, as dificuldades de obter ratificação do Congresso (no nível II - doméstico) são muito exploradas por negociadores

\footnotetext{
${ }^{559}$ PUTNAM, Robert D. Diplomacy and Domestic Politics: The Logic of Two-Level Games, p. 433-434.

560 MILNER, Helen. The Interaction of Domestic and International Politics: The Anglo-American Oil Negotiations and the International Civil Aviation Negotiations, 1943-1947. In: EVANS, Peter B.; JACOBSON, Harold K.; PUTNAM, Robert D. Double-edged diplomacy: international bargaining and domestic politics, $2^{\text {a }}$ ed. Berkeley: University of California Press, 1993, p. 229.

561 PUTNAM, Robert D. Diplomacy and Domestic Politics: The Logic of Two-Level Games, p. 437.

${ }^{562}$ Idem, p. 438.
} 
dos Estados Unidos no nível I (internacional), o que lhes favorece. ${ }^{563}$ Tal assertiva pode ser observada nas negociações ocorridas no âmbito da disputa da OMC US - Cotton, entre Brasil e Estados Unidos.

Existem três aspectos que repercutem sobre o tamanho do conjunto de vitórias: (i) as preferências e coalizões do nível II; (ii) as instituições do nível II; e (iii) as estratégias dos negociadores do nível I. ${ }^{564}$

O grau de participação dos grupos domésticos no processo de ratificação varia de acordo com os grupos e com as questões envolvidas, o que repercute sobre o tamanho do conjunto de vitórias. Ademais, a formação dos grupos domésticos ativos no nível II oscila também com o grau de politização do tema. Se o assunto for muito politizado, haverá mais grupos domésticos envolvidos no nível II (possivelmente com interesses diversos), dificultando a celebração de um acordo. Por isso os diplomatas destacam a importância do sigilo para negociações exitosas. ${ }^{565}$

Além disso, em uma negociação internacional geralmente há mais de um tema envolvido. Isso acarreta diversas consequências, já que os diferentes grupos do nível II tendem a apresentar preferências distintas sobre as questões envolvidas em uma negociação que engloba vários assuntos. Em decorrência disso, o negociador-chefe lida com barganhas cruzadas nos temas distintos de uma mesma negociação. ${ }^{566}$

Os procedimentos de ratificação repercutem sobre o tamanho do win-set. Nesse sentido, a separação de poderes nos Estados Unidos restringe o win-set em comparação com outros países. Consequentemente, o poder de barganha dos Estados Unidos torna-se maior, porque o Poder Executivo desse país pode alegar a dificuldade de aprovar determinada medida no Congresso. Desse modo, aumentaria a chance dos Estados Unidos conseguirem um acordo mais favorável aos seus interesses. Por outro lado, essa situação reduz a abrangência da cooperação internacional. ${ }^{567}$

Outro aspecto que merece destaque é que quanto maior a autonomia dos tomadores centrais de decisões em relação aos grupos domésticos do nível II, maior será seu conjunto de vitórias e, portanto, maiores as chances de obter um acordo internacional. Por outro lado, quanto maior a autonomia do Estado em comparação com as pressões

\footnotetext{
${ }^{563}$ PUTNAM, Robert D. Diplomacy and Domestic Politics: The Logic of Two-Level Games, p. 440.

${ }^{564}$ Idem, p. 442.

${ }^{565}$ Ibidem, p. 445.

${ }^{566}$ Ibidem, p. 446

${ }^{567}$ Ibidem, p. 448.
} 
domésticas exercidas no nível II, mais frágil será sua barganha internacional. ${ }^{568}$ Isso porque, como visto acima, esse Estado não poderá usar os interesses domésticos como justificativa para sugestões ao conteúdo do acordo no nível internacional.

Os negociadores do nível I almejam maximizar o conjunto de vitórias do outro negociador, mas, em relação ao seu próprio conjunto de vitórias, a situação é mais complexa. Isso porque quanto maior for o conjunto de vitórias do outro negociador, maior a facilidade de se concluir um acordo. Em contrapartida, se o seu conjunto de vitórias for elevado, seu poder de barganha em relação ao outro negociador será mais fraco. ${ }^{569} \mathrm{O}$ apoio incondicional no nível doméstico a acordos internacionais é geralmente maior em países menores, já que eles são mais dependentes de grandes economias. ${ }^{570}$

Há também outros fatores que repercutem sobre as negociações internacionais. Por exemplo, a boa reputação política de um negociador-chefe pode ajudar a ratificar suas iniciativas externas no âmbito doméstico. Outro exemplo corresponde ao nível hierárquico, já que chefes de governo têm maior probabilidade de dispor de mais compensações paralelas do que servidores de menor grau hierárquico. ${ }^{571}$

Os negociadores do nível I são geralmente mal informados sobre as políticas do nível II, especialmente as referentes à oposição. Salienta-se que a incerteza em relação ao tamanho do conjunto de vitória pode representar tanto um instrumento de barganha como um obstáculo (na medida em que aumenta o risco de defecção involuntária) nas negociações de dois níveis. Assim, numa negociação, o ideal é que o negociador conceda a certeza de que o acordo será ratificado, mas destaque a improbabilidade de ratificação caso o acordo seja um pouco mais favorável ao oponente. ${ }^{572}$

Cumpre elucidar algumas das motivações do negociador-chefe: (i) fortalecer sua posição no nível II por meio do aumento de recursos políticos ou por meio da redução de perdas potenciais; (ii) mudar o equilíbrio de poder no nível II a favor de políticas domésticas que prefere por motivos exógenos; e (iii) perseguir sua própria concepção de interesse nacional no contexto internacional. ${ }^{573}$

Num mundo com assimetria de poder, os países em desenvolvimento aumentam suas chances de sucesso se influenciarem atores relevantes do nível II nos

\footnotetext{
${ }^{568}$ PUTNAM, Robert D. Diplomacy and Domestic Politics: The Logic of Two-Level Games, p. 449.

${ }^{569}$ Idem, p. 450.

${ }^{570}$ Ibidem, p. 443.

${ }^{571}$ Ibidem, p. 451-452.

${ }^{572}$ Ibidem, p. 452-453.

${ }^{573}$ Ibidem, p. 457.
} 
países desenvolvidos. ${ }^{574}$ Esses atores, por sua vez, podem pressionar o governo de seus respectivos países a perseguirem os interesses deles no nível I. ${ }^{575}$ A disputa US - Cotton ilustra essa assertiva, na medida em que o setor dependente dos direitos de propriedade intelectual pressiona o governo dos Estados Unidos a cumprir a decisão da OMC. Outro exemplo disso, ocorrido em 2001, corresponde à parceria bem-sucedida entre os países em desenvolvimento e organizações não governamentais sediadas em países desenvolvidos com o intuito de flexibilizar o TRIPS em prol do acesso a medicamentos. A parceria conteve interesses dos Estados Unidos que, pressionado pela indústria farmacêutica, tentava tornar a interpretação do TRIPS mais rígida. ${ }^{576}$

Assim, os grupos de interesse domésticos não respondem somente de forma passiva aos potenciais acordos negociados entre governos, mas também buscam manipular (ao mesmo tempo em que são manipulados por) órgãos e líderes governamentais. As negociações internacionais devem considerar essa interação recíproca entre os atores dos níveis II (doméstico) e I (internacional) em suas estratégias ${ }^{577}$

Geralmente há uma autonomia relativa do chefe de governo em relação ao plano de política doméstica. Todavia, em certos casos, os interesses internos e internacionais podem se tornar mais importantes do que a estratégia desse tomador de decisão. ${ }^{578}$

\subsubsection{Ameaça: uma estratégia de barganha?}

Tendo em vista que até o momento nenhum país aplicou a retaliação cruzada em propriedade intelectual, torna-se importante analisar alguns aspectos sobre a ameaça nas negociações internacionais, já que os três Estados autorizados (Equador, Antígua e Brasil) esboçaram a implementação da medida, mas jamais a aplicaram.

As políticas domésticas correspondem a um fator importante para a credibilidade das ameaças internacionais, ${ }^{579}$ pois a ameaça torna-se mais crível quando for

\footnotetext{
${ }^{574}$ Exemplos de casos em que isso ocorreu podem ser analisados em SHAFFER, Gregory. The challenges of WTO law: strategies for developing countries adaptation, p. 194.

${ }^{575}$ Idem, p. 196.

${ }^{576}$ Ibidem, p. 194.

577 MORAVCSIK, Andrew. Introduction: Integrating International and Domestic Theories of International Bargaining, p. 22.

578 VENNESSON, Pascal. Idées, institutions et relations internationals. In: Revue française de science politique, n. 5, 1995. p. 857-864.

${ }^{579}$ MORAVCSIK, Andrew. Introduction: Integrating International and Domestic Theories of International Bargaining, p. 18.
} 
específica e detalhada (apresentando, por exemplo, produtos e valores envolvidos). ${ }^{580} \mathrm{Um}$ exemplo de ameaça crível remete ao caso US - Cotton, em que o Brasil promulgou lei sobre a retaliação cruzada em propriedade intelectual, além de realizar consultas públicas com o intuito de verificar quais seriam os setores objeto de retaliação.

Essa ameaça de retaliação cruzada geralmente enseja a celebração de um acordo entre os países envolvidos, com o intuito de evitar a retaliação. Isso ocorreu com o Equador $^{581}$, no caso EC - Bananas III, e com o Brasil no contencioso US - Cotton (embora no caso do Brasil não seja uma solução definitiva), conforme demonstrado no capítulo 3. Os negociadores devem se atentar ao custo (inclusive político) para obter o resultado negociado, verificando se a solução acordada representa um ganho para o seu país. ${ }^{582}$

Eventual empecilho ao cumprimento do acordo internacional pode ser encontrado dentro do país que ameaça aplicar a retaliação cruzada em propriedade intelectual. Se houver oposição interna à aplicação dessa retaliação, os atores domésticos podem convencer seu governo a não implementar determinada medida ou tornar o procedimento custoso politicamente. Por exemplo, as filiais de corporações multinacionais, que detêm mais de um terço do comércio mundial ${ }^{583}$, podem exercer pressão sobre o governo dos países onde estão instaladas, para que não seja aplicada a suspensão de direitos de propriedade intelectual, sob pena de suspender investimentos. Essa situação pode reduzir a credibilidade da ameaça. Portanto, a negociação internacional depende de determinado consenso interno. ${ }^{584}$ Aqui fica evidente a interação entre os níveis I e II da teoria dos jogos analisada.

Outra dificuldade pode ser encontrada dentro da nação ameaçada, caso o governo do país ameaçado perceba que os custos políticos internos de cumprir a medida solicitada por outro Estado são maiores do que as consequências de não realizar o acordo. ${ }^{585}$ Até o momento, é o que tem acontecido no caso US - Cotton, tendo em vista que a Farm Bill ainda não se adequou às decisões da OMC em decorrência da pressão contrária exercida pelo lobby do setor agrícola sobre o governo dos Estados Unidos.

\footnotetext{
580 ODELL, John S. International Threats and Internal Politics: Brazil, European Community, and the United States, p. 237.

${ }^{581}$ WHITEMAN, Allison L., Cross Retaliation Under the TRIPS Agreement: An Analysis of Policy Options for Brazil, p. 220.

582 ODELL, John S. International Threats and Internal Politics: Brazil, European Community, and the United States, p. 233.

583 GRIFFITHS, Martin. 50 Grandes estrategistas das relações internacionais. Trad. CASTRO, Vânia de, $2^{\mathrm{a}}$ ed. São Paulo: Contexto, 2011, p. 72.

584 ODELL, John S. International Threats and Internal Politics: Brazil, European Community, and the United States, p. 234.

${ }^{585}$ Idem, p. 234.
} 


\subsubsection{Teoria dos jogos de dois níveis no contencioso do algodão}

O caso US - Cotton exige uma análise mais complexa da teoria dos jogos de dois níveis, já que o nível II (doméstico) se expressa principalmente por meio de dois setores com interesses contrários dentro de ambos os países: o agrícola e o setor dependente de direitos de propriedade intelectual (destacando-se a atuação da indústria farmacêutica, de software e de entretenimento). Isso ocorre porque a decisão de US Cotton requer a alteração da Farm Bill, mudança que não está de acordo com os interesses agrícolas. Caso a Farm Bill não seja alterada conforme a decisão da OMC, o Brasil possui direito de aplicar a retaliação cruzada em propriedade intelectual. Essa possível retaliação prejudica o setor industrial dos Estados Unidos, principalmente o farmacêutico, de entretenimento e de software.

O cumprimento de decisões do sistema de solução de controvérsias da OMC geralmente depende do poder do demandante de induzir o retaliado, por meio de retaliações bilaterais. ${ }^{586}$ Quando há assimetria no comércio bilateral entre as partes envolvidas em uma disputa na OMC, induzir o cumprimento de uma decisão do OSC torna-se mais difícil. Nesse caso, é necessário utilizar ferramentas que aumentem a pressão sobre o governo do país que violou as regras da OMC. A autorização para aplicar a retaliação cruzada em propriedade intelectual incentiva o setor privado que depende desses direitos a pressionarem o governo de seu país a cumprir a decisão da OMC. Mas a fórmula não é tão simples: em geral, há também um lobby poderoso dentro do país que dificulta a remoção da medida que viola a OMC. No caso US - Cotton, esse lobby poderoso é realizado pelo setor agrícola.

Diferentemente do Equador e de Antígua, o Brasil é uma das maiores economias do mundo, com potencial industrial e capacidade de aplicar a retaliação cruzada. Com o direito de realizar a retaliação cruzada, o Brasil pode colocar dois poderosos setores norte-americanos em posições antagônicas. O setor relativo à agricultura é bem representado no Congresso dos Estados Unidos e os subsídios do algodão denotam os reflexos deste lobby. Por outro lado, os Estados Unidos têm muito interesse na proteção

\footnotetext{
${ }^{586}$ MEDRADO, Renê G. da Silva. Retaliação coletiva e teoria de formação de alianças no sistema de solução de controvérsias da Organização Mundial do Comércio. Tese de doutorado não publicada, Faculdade de Direito da Universidade de São Paulo, 2011, p. 209.
} 
dos direitos de propriedade intelectual, ${ }^{587}$ conforme descrito no capítulo 2, e o setor industrial exerce uma pressão sobre o governo norte-americano em prol da reforma da sua política agrícola.

Sabe-se que a alteração da Farm Bill norte-americana é um enorme desafio, tendo em vista que não se trata apenas do algodão, mas de incentivos a diversos produtos agrícolas. Os motivos que justificam a concessão de subsídios agrícolas nos Estados Unidos devem ser analisados, a fim de compreender a possibilidade de alteração da Farm Bill.

\subsection{A interação entre os setores público e privado nos Estados Unidos}

A importância política e econômica da indústria do algodão influencia na possibilidade de alterar a Farm Bill para torná-la de acordo com as regras e decisões da OMC. Nesse contexto, é importante entender a importância e atuação do setor agrícola nos Estados Unidos, com destaque para o setor cotonicultor. Em seguida, será descrita uma nova coalizão que envolve o setor intensivo em propriedade intelectual, complementando a ideia da organização desse setor apresentada no capítulo 2.

\subsection{Aspectos econômicos do algodão}

Entre 2003 e $2004^{588}$, os Estados Unidos eram o segundo produtor mundial de algodão (após a China), mas correspondiam ao primeiro exportador. As exportações estadunidenses do algodão nesta época ${ }^{589}$ eram mais de 7 vezes superiores às do segundo exportador (Austrália). ${ }^{590}$ No período analisado, cerca de $70 \%$ do algodão produzido nos Estados Unidos foi exportado. Isso demonstra a capacidade de controlar os preços internacionais do produto no início da disputa, bem como a importância das exportações para o setor cotonicultor estadunidense.

Os estados norte-americanos que produzem algodão são 17: Alabama, Arizona, Arkansas, Califórnia, Flórida, Georgia, Kansas, Louisiana, Mississipi, Missouri, Novo

${ }^{587}$ WHITEMAN, Allison L., Cross Retaliation Under the TRIPS Agreement: An Analysis of Policy Options for Brazil, p. 190.

588 O relatório do painel da disputa US - Cotton foi circulado em 2004. Disponível em: <www.wto.org/english/tratop_e/dispu_e/cases_e/ds267_e.htm>. Acesso em 14/08/2013.

589 Em 2010, a China já era o principal exportador de algodão do mundo. Disponível em $<$ www.indexmundi.com/trade/exports/?chapter=52> . Acesso em 11/08/2013.

590 Disponível em <www.nationmaster.com/graph/agr_cot_exp-agriculture-cotton-exports>. Acesso em 11/08/2013. 
México, Carolina do Norte, Oklahoma, Carolina do Sul, Tennessee, Texas e Virgínia. Esses locais formam o cinturão do algodão. ${ }^{591}$ Para os 9 dos 17 estados do cinturão do algodão, este produto tem importância econômica. ${ }^{592}$

Nos Estados Unidos, a agricultura representa menos de 2\% do Produto Nacional Bruto (PNB) ${ }^{593}$, enquanto o setor industrial tem participação mais de 10 vezes superior ao agrícola. ${ }^{594}$ A agricultura representa menos de $10 \%$ das exportações dos Estados Unidos e o algodão, especificamente, representa menos de 1\% das exportações do país. Porém, o setor agrícola é relevante para reduzir o déficit na conta corrente do país: ${ }^{595}$ em 2012, o setor agrícola teve superávit superior a US\$ 30 bilhões nos Estados Unidos. ${ }^{596}$

Considerando que há outros setores com mais poder econômico do que o agrícola nos Estados Unidos, verifica-se que a dificuldade de alterar a Farm Bill é mais política do que econômica.

\title{
4.3.1.3.3. Aspectos políticos do setor cotonicultor
}

A influência do setor agrícola na política norte-americana é notória. Nesse sentido, destaca-se o desafio do Brasil ao instaurar o contencioso do algodão na OMC:

\begin{abstract}
O contencioso não era apenas inédito, era também complexo. Do ponto de vista político, o Brasil estaria questionando nada mais, nada menos do que o cerne da estrutura de apoio à agricultura norte-americana, enraizada, desde pelo menos a década de 30 do século 20, no cenário político e no imaginário do povo norteamericano; programas que se aplicam não só ao algodão, mas também a várias outras commodities, de grande relevo na pauta das exportações agrícolas norteamericanas. Talvez mais importante ainda: o Brasil estaria questionando privilégios de um dos lobbies mais bem estruturados e mais poderosos dos EUA - os chamados "barões do algodão". 597
\end{abstract}

Desse modo, é necessário compreender alguns aspectos do poder político detido pelo setor do algodão nos Estados Unidos.

\footnotetext{
591 LIMA, Thiago. As relações entre executivo, legislativo e grupos de interesse norte-americanos no contencioso do algodão. In: Cadernos CEDEC, $\mathrm{n}^{\circ}$ 73, 2005, p. 35.

${ }^{592}$ Idem, p. 42.

593 Produto Nacional Bruto corresponde ao valor agregado de todos os bens e serviços decorrentes da mobilização de recursos nacionais (pertencentes a residentes no país), independente do território econômico em que esses recursos foram produzidos. A diferença entre o PNB e o PIB remete à renda líquida enviada ou recebida do exterior. Disponível em <www12.senado.gov.br/noticias/glossario-legislativo/PNB >. Acesso em $11 / 08 / 2013$

${ }^{594}$ Disponível em < stats.oecd.org/Index.aspx?DatasetCode=SNA_TABLE1>. Acesso em 11/08/2013.

595 LIMA, Thiago. As relações entre executivo, legislativo e grupos de interesse norte-americanos no contencioso do algodão, p. 37-39.

${ }^{596}$ Disponível em < usda01.library.cornell.edu/usda/ers/AES//2010s/2012/AES-11-29-2012.pdf>. Acesso em 11/08/2013.

${ }^{597}$ AZEVÊDO, Roberto. Depoimento, p. 91.
} 


\subsection{A organização política da indústria do algodão}

O National Cotton Council of America (NCC) é a organização dos Estados Unidos que congrega sete segmentos industriais (incluindo produtores e comerciantes) dos 17 estados produtores do cinturão do algodão nos Estados Unidos para solucionar problemas comuns e desenvolver programas de benefício mútuo. O NCC representa o setor nas negociações com o governo, para assegurar que os interesses do algodão serão considerados. $^{598}$

Um exemplo de ação do NCC remete ao contencioso US - Cotton, em que a entidade atuou como um dos grupos de interesse, junto com o USTR, os Comitês de Agricultura do Congresso e o Departamento de Agricultura dos Estados Unidos (United States Department of Agriculture - USDA). ${ }^{599}$ O USTR teve como função coordenar, realizar consultas, informar e formular a posição oficial dos Estados Unidos no contencioso US - Cotton. ${ }^{600}$

A organização da indústria do algodão e sua bem-sucedida interlocução com representantes do governo dos Estados Unidos auxilia os cotonicultores a terem seus interesses representados no Congresso norte-americano.

\subsection{Sistema eleitoral}

Medidas que reduzam a competitividade do setor cotonicultor estadunidense são impopulares para as pessoas que trabalham ou dependem dessa indústria no país. A indústria do algodão empregou aproximadamente 200 mil pessoas em 2012 nos Estados Unidos, em mais de 20 mil estabelecimentos. ${ }^{601}$ Ou seja, há cerca de 200 mil potenciais eleitores com interesse na produção do algodão. ${ }^{602}$

Todavia, esse número é ínfimo se comparado com o número de eleitores dos Estados Unidos, mesmo se consideradas outras culturas (ou seja, todo o setor agrícola) do

\footnotetext{
${ }^{598}$ Disponível em <www.cotton.org/about/index.cfm>. Acesso em 11/08/2013.

599 LIMA, Thiago. As relações entre executivo, legislativo e grupos de interesse norte-americanos no contencioso do algodão, p. 53.

${ }^{600}$ Idem, p. 54.

${ }^{601}$ Disponível em <www.cotton.org/econ/world/detail.cfm>. Acesso em 11/08/2013.

${ }^{602} \mathrm{O}$ número pode variar se considerar que há familiares de empregados que podem ser influenciados (e refletir isso no voto) por questões do algodão. O número também pode diminuir se não englobar apenas cidadãos norte-americanos com direito a voto. Nesse sentido, vide: LIMA, Thiago. As relações entre executivo, legislativo e grupos de interesse norte-americanos no contencioso do algodão, p. 43.
} 
país. ${ }^{603}$ Além disso, esse provavelmente não seria o único aspecto considerado pelo eleitor no momento de votar. Desse modo, as eleições não são suficientes para justificar o poder político agrícola nos Estados Unidos.

Um dos fatores que explica o poder político do setor agrícola nos Estados Unidos é o sistema do voto distrital. Esse sistema, em vigor nos Estados Unidos, torna os representantes do Congresso mais próximos de seus eleitores. Nesse contexto, destaca-se a importância do algodão no plano distrital:

O algodão, beneficiado ou não, tem importância bastante reduzida para o total exportado pelo país. Todavia, é preciso reconhecer que o produto é um dos maiores da pauta agrícola. Isso significa que os cotonicultores ocupam uma posição importante no universo rural norte-americano e que pode se transformar em força política em função do sistema distrital para a ocupação de cargos eletivos no Congresso. Esse sistema consiste em divisões territoriais pelas quais se elegem os deputados (representatives) de cada estado. ${ }^{604}$

Dos 438 distritos congressionais norte-americanos em 2004, 213 pertencem aos estados do cinturão do algodão. Essa cultura está presente em 111 desses distritos, ou seja, mais do que na metade deles. (...) Desses 111 distritos, o algodão ocupa posição de destaque em 41 deles em termos de vendas, e em 54 em termos de área plantada. Isso significa que essa cultura possui relevância ainda maior para o campo em nível distrital do que para os estados, e que pode ser potencializada em função das características do sistema eleitoral distrital norte-americano. $^{605}$

Portanto, o voto distrital é um fator relevante para compreender o poder do setor agrícola norte-americano, pois o sistema altera a representatividade da agricultura.

\subsection{Doações financeiras para campanhas eleitorais}

Dados do Center for Responsive Politics demonstram que o setor de saúde e de comunicação foram, respectivamente, o $5^{\circ}$ e o $7^{\circ}$ setores que mais financiaram campanhas eleitorais nos Estados Unidos em 2012. Por outro lado, observa-se que o agronegócio foi o $11^{\circ}$ maior contribuinte no país no mesmo período. ${ }^{606}$

O setor de saúde inclui a indústria farmacêutica e o de comunicação engloba o setor de informática e de entretenimento. Todas essas indústrias dependem da proteção dos direitos de propriedade intelectual, conforme demonstrado no capítulo 2. Ou seja, esses

\footnotetext{
${ }^{603}$ LIMA, Thiago. Desafios internacionais à política agrícola norte-americana: o contencioso do algodão entre Brasil e Estados Unidos e o CAFTA-DR. Dissertação de mestrado não publicada, Programa de PósGraduação em Relações Internacionais ‘San Tiago Dantas’ UNESP-UNICAMP-PUC/SP, 2008, p. 126.

${ }^{604}$ LIMA, Thiago. As relações entre executivo, legislativo e grupos de interesse norte-americanos no contencioso do algodão, p. 39.

${ }^{605}$ Idem, p. 42.

${ }^{606}$ Dados disponíveis em <www.opensecrets.org/overview/sectors.php>. Acesso em 11/08/2013.
} 
defensores dos direitos de propriedade intelectual doam mais recursos para as campanhas eleitorais (somados, ambos doaram cerca de US\$ 468 milhões em 2012) do que o setor agrícola $^{607}$, que doou aproximadamente US\$ 92 milhões em 2012. Por qual motivo essa influência política não conseguiu reverter o descumprimento dos Estados Unidos na disputa US - Cotton?

O setor agrícola tem mais influência sobre os órgãos responsáveis pela reedição da Farm Bill, como os Comitês agrícolas da Câmara e do Senado. As indústrias dependentes dos direitos de propriedade intelectual, por sua vez, direcionam seus recursos a campanhas de outros atores, mais relacionados ao setor industrial. Nesse sentido, destaca-se que:

\begin{abstract}
Os políticos podem criar regras que beneficiem sua base social em troca de votos e de recursos para suas campanhas, o que gera um círculo vicioso. No que toca aos recursos para campanhas, é importante observar que parte das doações dos grupos de interesse acaba saindo dos próprios recursos dos programas federais. Essas características criam condições políticas para que, tradicionalmente, o algodão esteja entre os maiores beneficiários dos programas agrícolas. Estas condições são potencializadas pelo enviesamento institucional favorecido pela estrutura legislativa abrangente da Farm Bill e pelos Comitês de Agricultura do Senado e da Câmara, este último considerado bastante paroquial. ${ }^{608}$
\end{abstract}

\title{
4.3.1.3.7. Perspectivas de alteração da Farm Bill
}

A produção nacional de algodão rendeu US\$ 4,2 bilhões em 2000, US\$ 3,1 bilhões em 2001, US\$ 3,7 bilhões em 2002 e US\$ 5,5 bilhões em 2003. Os resultados do último ano mencionado podem ser atribuídos à Farm Bill de $2002 .{ }^{609}$ Esses números demonstram a importância da Farm Bill para o setor agrícola norte-americano.

A redução de subsídios ao algodão diminuiria a receita dos produtores estadunidenses. Eventual aumento de preço, para manter a receita anteriormente obtida, reduziria a competitividade no mercado mundial. A situação agrava-se considerando que a alteração da Farm Bill não se restringe à cultura do algodão: seriam impactados diversos outros produtos agrícolas. Nesse contexto, torna-se importante compreender a formulação e reedição da Farm Bill:

Primeiro, trata-se de questões core para os Comitês de Agricultura da Câmara e do Senado, como programas de suporte à renda e a preços, contando com o apoio político de parlamentares não diretamente interessados nessas questões. É nesse estágio que há ação intensa dos lobbies agrícolas mais poderosos demandando

\footnotetext{
${ }^{607}$ O setor agrícola é considerado como um todo aqui porque as mudanças exigidas pela disputa US - Cotton na Farm Bill impactam sobre toda esta indústria, e não apenas sobre a cultura do algodão.

${ }^{608}$ LIMA, Thiago. As relações entre executivo, legislativo e grupos de interesse norte-americanos no contencioso do algodão, p. 54.

${ }^{609}$ Idem, p. 36.
} 
auxílios de diferentes tipos e graus, muitos dos quais considerados como subsídios pela OMC. É aqui que são definidos os programas centrais, a coluna vertebral da Farm Bill.

No segundo estágio, os parlamentares com interesses marginais nesses programas, como aqueles oriundos de distritos mais “urbanos”, para apoiarem os elementos centrais dessa lei exigem como barganha apoio de parlamentares interessados diretamente na questão agrícola eleitos por distritos mais "rurais", para suas propostas “não-rurais” (nonfarm), como proteção a animais e uso de energia, por exemplo. ${ }^{610}$

Embora houvesse preocupação com o respeito às regras internacionais na elaboração da Farm Bill, o interesse doméstico prevaleceu. Vale lembrar que situação semelhante ocorreu no âmbito da conclusão do TRIPS e a tentativa de supressão do mecanismo unilateral conhecido como Special 301, conforme descrito no capítulo 2, quando o interesse doméstico também se sobrepôs aos tratados multilaterais.

Economicamente, os setores dependentes de direito de propriedade intelectual são mais importantes para os Estados Unidos. Enquanto a agricultura representa cerca de $1 \%$ do PIB dos Estados Unidos ${ }^{611}$, as indústrias intensivas em propriedade intelectual correspondem a aproximadamente 35\% do PIB do país. ${ }^{612}$

Considerando a maior importância econômica dos setores farmacêutico, de informática e de entretenimento em comparação com o agrícola, o Poder Executivo dos Estados Unidos pode adotar certas medidas para contornar os obstáculos encontrados no Congresso. Como não é possível sobrepor-se ao Congresso, o Poder Executivo, no contencioso do algodão, autorizou a realização de pagamentos mensais ao setor cotonicultor brasileiro. Trata-se de uma compensação, que não resolve a ilegalidade da Farm Bill, mas mitiga os efeitos negativos sobre o Brasil. Porém, não é solucionada a questão de forma sistêmica e, desse modo, outros países (como os africanos), permanecem prejudicados com a medida.

Diante do exposto, a total adequação da Farm Bill às regras e decisões da OMC parece improvável no cenário atual, tendo em vista o lobby do setor agrícola que é exercido sobre os responsáveis pela alteração da Farm Bill. A despeito da influência e da importância do setor dependente dos direitos de propriedade intelectual, essa indústria não conseguiu, até o momento, progressos além daqueles que foram obtidos no “AcordoQuadro para uma Solução Mutuamente Acordada para o Contencioso do Algodão na

${ }^{610}$ OLIVEIRA, Marcelo Fernandes de. Negociações comerciais internacionais e democracia no Brasil: contenciosos das patentes, do algodão e do açúcar na OMC. Tese de doutorado não publicada, Faculdade de Filosofia, Letras e Ciências Humanas da Universidade de São Paulo, 2012, p. 133-134.

${ }^{611}$ Dado referente a 2011. Disponível em: <data.worldbank.org/indicator/NV.AGR.TOTL.ZS>. Acesso em 14/08/2013.

${ }^{612}$ Disponível em: <www.uspto.gov/about/ipm/industries_in_focus.jsp>. Acesso em 14/08/2013. 
Organização Mundial do Comércio (WT/DS267)”. Estão sendo discutidas reduções dos subsídios agrícolas norte-americanos, mas sua eliminação não parece provável em um futuro próximo.

Há também outros oponentes aos subsídios agrícolas nos Estados Unidos: os fazendeiros (que não os recebem e são prejudicados pelos efeitos negativos da concessão de subsídios); grupos preocupados com ajuste fiscal; ambientalistas; associações de contribuintes que julgam os subsídios uma alocação ineficiente de recursos; e algumas organizações não governamentais. Porém, esses grupos já lutam há vários anos, sem sucesso, para a redução dos subsídios agrícolas. A pressão orçamentária e a decisão da OMC podem contribuir para mudar esse cenário, embora ainda haja resistência de congressistas relacionados à agricultura. ${ }^{613}$

\subsubsection{8. $\quad$ Brazil Trade Action Coalition (BRAZTAC)}

Criada em 2010, a Brazil Trade Action Coalition (BRAZTAC) engloba empresas e associações dos Estados Unidos relacionadas a diversos segmentos, como agricultura, manufatura, serviços e tecnologia (incluindo o setor farmacêutico e de entretenimento), que apoiam uma solução definitiva para a disputa US - Cotton, com o intuito de evitar a retaliação do Brasil em face dos Estados Unidos. ${ }^{614}$

A BRAZTAC apoiou a celebração do memorando de entendimentos entre Brasil e Estados Unidos, em 2010. Nos anos seguintes, atuou no Congresso norteamericano para evitar, em cinco ocasiões, o desmantelamento do Acordo-Quadro celebrado entre Brasil e Estados Unidos. ${ }^{615}$

A entidade é mais um exemplo, além dos mencionados no capítulo 2, da organização do setor intensivo em propriedade intelectual (embora congregue também outros setores) para realizar a interlocução com o governo dos Estados Unidos. A realização da pressão desse setor sobre o governo é mais um exemplo da aplicação da teoria dos jogos de dois níveis.

\footnotetext{
${ }^{613}$ LIMA, Thiago. As relações entre executivo, legislativo e grupos de interesse norte-americanos no contencioso do algodão, p. 57.

${ }^{614}$ Disponível em: <www.brazilcouncil.org/initiatives/braztac>. Acesso em 06/03/2013.

${ }^{615}$ Disponível em: <www.brazilcouncil.org/initiatives/braztac>. Acesso em 14/08/2013.
} 


\section{CONCLUSÃO}

Como visto no capítulo 1, o sistema de solução de controvérsias da OMC é composto por etapas. Após uma decisão favorável do painel ou Órgão de Apelação, caso não haja implementação das decisões do OSC, deve-se tentar realizar a compensação. Posteriormente, pode-se solicitar ao OSC a suspensão de concessões ou outras obrigações (retaliação). De acordo com o artigo 22.3 do ESC, a suspensão de concessões ou outras obrigações deve seguir uma ordem. Primeiro deve-se tentar retaliar no mesmo setor em que foi constatada violação da regra na OMC. Caso não seja possível, deve-se buscar outro setor no mesmo acordo em que ocorreu a violação. Se nenhuma das duas hipóteses mencionadas ocorrer, é possível solicitar autorização para aplicar a retaliação em outro acordo, conhecida como retaliação cruzada.

Ultrapassadas todas as etapas anteriores ao pedido de retaliação cruzada, devese também preencher certos requisitos previstos no artigo 22.3 do ESC. Os três precedentes da retaliação cruzada (EC - Bananas III; US - Gambling e US - Cotton) demonstram que a interpretação foi uniforme na maioria dos requisitos, conforme verificado no capítulo 3 . O entendimento constante nesses casos pode inspirar os demais países em desenvolvimento a utilizarem o mecanismo, com o intuito de obter a efetiva implementação da decisão da OMC.

Tendo em vista que o setor de propriedade intelectual é essencial para a economia dos países desenvolvidos, consoante demonstrado no capítulo 2, a eficácia da autorização da retaliação cruzada em propriedade intelectual aumenta quando o país demandado corresponde a um país desenvolvido. Assim, os países em desenvolvimento dispõem de um mecanismo poderoso que é a autorização para aplicar a retaliação cruzada em propriedade intelectual.

A mera ameaça de utilização já representa um poder de barganha nas negociações, desde que haja uma ameaça crível, que está intrinsecamente relacionada à capacidade do país aplicar a retaliação em propriedade intelectual. Como já demonstrado, a capacidade de retaliar geralmente encontra-se em países em desenvolvimento de maior porte (emergentes), como Brasil, Índia, China, México e Rússia. Os demais países em desenvolvimento podem buscar medidas para ampliar o efeito do mecanismo, como o uso da internet. Todavia, o uso de internet aumenta a dificuldade de controlar as condições impostas pela OMC para suspender os direitos de propriedade intelectual. 
Apesar de os países emergentes terem mais benefícios com a autorização da retaliação cruzada do que os de menor porte (tendo em vista a capacidade de retaliar), a dificuldade para comprovar os requisitos da retaliação cruzada são maiores. Nesse sentido, na decisão do caso US - Cotton, analisada no capítulo 3, os árbitros entenderam que o desequilíbrio significativo nas relações bilaterais não foi suficiente para solicitar a retaliação cruzada. Assim, nessa disputa, a suspensão de direitos de propriedade intelectual só foi autorizada após a retaliação em bens até determinado montante.

A viabilidade de suspender os direitos de propriedade intelectual também remete à existência de permissão legal no âmbito interno do país retaliante. Em certos casos, as normas internacionais são auto-executáveis, como no do Equador, mas em outros é necessário promulgar lei sobre o tema, como ocorreu no Brasil. Ainda que haja a referida permissão legal, é possível que a retaliação em propriedade intelectual seja objeto de inúmeras demandas judiciais. Esse risco aumenta quando a propriedade intelectual é protegida na Constituição, como no Brasil. Não há certeza quanto à interpretação dos tribunais sobre o tema, mas o mero risco de anulação da suspensão de direitos de propriedade intelectual já deve ser considerado na decisão dos países de retaliar.

A suspensão de direitos de propriedade intelectual engloba outras dificuldades, incluindo a limitação do montante; a retaliação direcionada ao membro da OMC que descumpriu a decisão e o caráter temporário da medida. A incerteza relacionada aos aspectos mencionados gera imprevisibilidade no âmbito dos negócios. Consequentemente, pode haver menos empresas e investidores interessados em utilizar a mecanismo da retaliação cruzada no país retaliante. Ainda que existam certas prerrogativas a esses atores do setor privado que aplicarem a retaliação cruzada em propriedade intelectual, como prevê a lei brasileira $n^{\circ} 12.270 / 2010$, o risco do negócio persiste (representado, por exemplo, por um questionamento judicial). Portanto, cabe aos empresários sopesar a possibilidade de lucro e o risco de usar o mecanismo em cada caso.

O desafio torna-se ainda maior considerando que o país que aplicar a retaliação cruzada em propriedade intelectual terá consideráveis custos de fiscalização da medida. Caso a aplicação desrespeite alguma das condições impostas pela OMC, o país retaliante pode ser questionado no sistema de solução de controvérsias da Organização. Os recursos humanos e financeiros que deverão ser investidos no momento da aplicação da medida (em prol da fiscalização dessa implementação) também devem ser considerados pelo país que cogite suspender direitos de propriedade intelectual. Em suma, observa-se a dificuldade de aplicar a retaliação cruzada em propriedade intelectual. O desafio é ainda maior para os 
países em desenvolvimento de menor porte, que tem menos recursos e infraestrutura para implementar essa retaliação.

O Brasil promulgou lei que considera todas as condições impostas pela OMC para aplicar a retaliação cruzada, além de realizar consultas públicas antes de aplicar a retaliação em bens e propriedade intelectual, o que aumenta a previsibilidade para os atores envolvidos. O sucesso da atuação até o momento é resultado de um notável esforço do governo brasileiro, que incluiu a participação do setor privado e de especialistas em propriedade intelectual. Entretanto, mesmo com toda a cautela necessária e um mercado importante para o país que eventualmente será retaliado, o Brasil enfrenta desafios, destacando-se os aspectos da fiscalização e o risco de ser questionado no Poder Judiciário.

No tocante à questão analisada no presente trabalho, qual seja, verificar se a autorização para aplicar a retaliação cruzada em propriedade intelectual induz o cumprimento de decisões adotadas pelo OSC, nota-se que Equador e Brasil (demandantes nas disputas EC - Bananas III e US - Cotton, respectivamente) obtiveram algumas vitórias, mas a decisão adotada pelo OSC não foi totalmente adotada - embora a disputa US - Cotton ${ }^{616}$ ainda esteja em andamento.

Para a celebração dos acordos nos casos EC - Bananas III e US - Cotton $^{617}$, a autorização da implementação da retaliação cruzada foi essencial. No segundo caso, o entendimento entre Brasil e Estados Unidos ocorreu logo após a ameaça de aplicação do mecanismo autorizado pela OMC. Para compreender o poder da suspensão de direitos de propriedade intelectual, é necessário analisar o caso à luz da teoria dos jogos de dois níveis, que descreve a interação entre os setores público e privado nas negociações internacionais. A ameaça de retaliação cruzada movimenta o lobby dos setores intensivos em propriedade intelectual sobre o governo do país demandado para tornar a medida violada em consonância com as regras da OMC. Esses setores temem a criação de precedentes da retaliação cruzada na OMC.

Contudo, o lobby dos setores de propriedade intelectual não atua sozinho: ele geralmente possui outro setor poderoso atuando no sentido contrário. Nas disputas EC Bananas III e US - Cotton, esse segundo setor era o agrícola. Por esse motivo, muitas vezes a medida que violou regras na OMC não é totalmente cumprida. Diante desse cenário, o lobby da propriedade intelectual busca uma alternativa para evitar a retaliação, que geralmente são compensações ao país com autorização para retaliar, como ocorreu nas

\footnotetext{
${ }^{616}$ Assim como o caso US - Gambling, que será anaisado adiante.

${ }^{617} \mathrm{Na}$ disputa US - Cotton o entendimento é temporário por enquanto.
} 
controvérsias EC - Bananas III e US - Cotton. Ou seja, a autorização para aplicar a retaliação cruzada em propriedade intelectual tem reduzido impacto sistêmico para a OMC, pois há dificuldade no âmbito doméstico para cumprir certas decisões da Organização. Porém, o país demandante tem sido compensado pelas práticas que contrariam as regras e decisões da OMC.

No caso US - Gambling, isso ainda não ocorreu. Na realidade, um acordo com os Estados Unidos é o que o país tem buscado, conforme declarações dos representantes do governo de Antígua. Como Antígua é um pequeno país em desenvolvimento, sua capacidade para aplicar a retaliação cruzada em propriedade intelectual é menor. Neste caso, eventual acordo deve demorar mais para ser celebrado, como ocorreu com o Equador na disputa EC - Bananas III.

Já o Brasil, um país emergente, obteve mais sucesso na celebração do acordo (temporário, neste caso) com os Estados Unidos, pois a ameaça de aplicação da retaliação cruzada era mais crível do que nos dois outros precedentes. A capacidade de o Brasil implementar a retaliação cruzada era maior e a lei brasileira $n^{0}$ 12.270/2010 foi bem elaborada, demonstrando a preocupação com diversas exigências da OMC. Esse motivo e a importância do mercado do Brasil para o setor intensivo em propriedade intelectual dos Estados Unidos acelerou a celebração do acordo que está vigente entre os dois países.

Porém, esse acordo do Brasil prevê a alteração da Farm Bill, cerne da política agrícola norte-americana. Mesmo que haja modificações nessa legislação, dificilmente ela será totalmente adequada à decisão da OMC, conforme mencionado no capítulo 4. Neste caso, o Brasil teria a prerrogativa de aplicar a retaliação cruzada em propriedade intelectual, que já foi autorizada pela OMC.

Os precedentes da autorização de retaliação cruzada em propriedade intelectual têm demonstrado que a negociação é uma solução melhor do que a implementação da retaliação, que apresenta diversas dificuldades demonstradas no capítulo 4. Considerando que o principal objetivo do sistema de solução de controvérsias é tornar a medida violada em consonância com as decisões e regras da OMC, em princípio, não se busca aplicar retaliação. Ela surge como uma alternativa, uma tentativa de compensar os prejuízos causados pela medida questionada na OMC.

Indaga-se qual deveria ser a postura do país demandado caso o acordo celebrado com o demandado não seja totalmente cumprido. No caso do Brasil, na disputa US - Cotton, ainda seria possível utilizar a prerrogativa de aplicar a retaliação cruzada. 
Tendo em vista as dificuldades de implementar o mecanismo da retaliação cruzada, o país demandante deve ponderar se o benefício de implantar a retaliação cruzada seria, no caso concreto, maior do que os custos econômicos e políticos. Essa decisão deve também considerar a credibilidade da ameaça do país em futuras controvérsias da OMC.

A dinâmica da autorização da retaliação cruzada deve ser observada sob o prisma da teoria dos jogos de dois níveis, pois se utiliza os atores domésticos (“nível II”) que neste caso corresponde aos setores intensivos em propriedade intelectual - para modificar ações do governo (“nível I”) do país demandado na OMC. Como os países em desenvolvimento possuem menor poder econômico do que os países desenvolvidos, os atores domésticos do país demandado auxiliam a pressionar o governo do país que eventualmente será retaliado, aumentando as chances de vitória dos países em desenvolvimento. Alguns fatores podem dificultar esse processo, como a dificuldade do Poder Executivo alterar decisões do Poder Legislativo.

Em suma, observa-se que a autorização do OSC para aplicar a retaliação cruzada em propriedade intelectual pode auxiliar os países em desenvolvimentos que tiverem uma decisão favorável da OMC em controvérsia contra um país desenvolvido. O impacto dessa autorização será diretamente proporcional à credibilidade da ameaça, baseada em questões fáticas (incluindo capacidade de retaliar) e jurídicas. 


\section{BIBLIOGRAFIA}

\section{LIVROS}

AMARAL JÚNIOR, Alberto do. A Solução de Controvérsias na OMC e a Aplicação do Direito Internacional. São Paulo, Atlas, 2008.

BARRAL, Welber (org.). Direito e desenvolvimento: análise da ordem jurídica brasileira sob a ótica do desenvolvimento. São Paulo: Singular, 2005.

- O Brasil e a OMC: os interesses brasileiros e as futuras negociações multilaterais. Florianópolis: Diploma legal, 2000.

BASSO, Maristela. O direito internacional da propriedade intelectual. Porto Alegre: Livraria do Advogado, 2000.

. Propriedade intelectual na era pós-OMC. Porto Alegre: Livr. do Advogado, 2005.

CELLI JÚNIOR, Umberto. Comércio de Serviços na OMC: Liberalização, Condições e Desafios. Curitiba: Juruá, 2009.

CERQUEIRA, Gama. Tratado da Propriedade Industrial. $2^{\mathrm{a}}$ ed. vol. $1^{\mathrm{o}}$. São Paulo: Revista dos Tribunais, 1982.

CORREA, Carlos M. Trade related aspects of intellectual property rights : a commentary on the TRIPS agreement. Oxford: Oxford University Press, 2007.

GAMA CERQUEIRA, João da. Tratado da Propriedade Industrial, v. 1, $2^{\mathrm{a}}$ Ed. São Paulo: Revista dos Tribunais, 1982.

GREENHALGH, Christine; ROGERS, Mark. Innovation, intellectual property, and economic growth. Princeton: Princeton University Press, 2010.

GRIFFITHS, Martin. 50 Grandes estrategistas das relações internacionais. Trad. CASTRO, Vânia de, $2^{\mathrm{a}}$ ed. São Paulo: Contexto, 2011.

LAFER, Celso. A OMC e a regulamentação do comércio internacional. Porto Alegre: Livraria do Advogado, 1998.

LANDES, William M.; POSNER, Richard. The Economic Structure of Intellectual Property Law. Cambridge: Harvard University Press. 2003.

LOWENFELD, Andreas F. International Economic Law, $2^{\mathrm{a}}$ ed. Oxford: Oxford University Press, 2008.

MATHÉLY, Paul. Le droit européen des brevets d'invention. Paris : Journal des notaires et des avocats, 1978. 
MATSUSHITA, Mitsuo; SCHOENBAUM, Thomas J.; MAVROIDIS, Petros C. The World Trade Organization: Law, Practice and Policy. New York: Oxford International Law Library, 2003.

PAUWELYN, Joost. Conflicts of Norms in Public International Law: How WTO Law Relates to Other Rules of International Law. Cambridge: University Press, 2003.

NASSER, Rabih Ali. A OMC e os Países em Desenvolvimento. São Paulo: Aduaneiras, 2002.

SHERWOOD, Robert M. Propriedade Intelectual e Desenvolvimento Econômico, tradução de Heloísa de Arruda Villela. São Paulo: Editora da Universidade de São Paulo, 1992.

SILVEIRA, Newton. Propriedade intelectual: propriedade industrial, direito de autor, software, cultivares, nome empresarial. $4^{\mathrm{a}}$ ed., Barueri: Manole, 2011.

SIRINELLI, Pierre. Propriété littéraire et artistique, 2ª ed.. Paris: Dalloz, 2003

THORSTENSEN, Vera. OMC - Organização Mundial do Comércio: as regras do comércio internacional e a nova rodada de negociações multilaterais. $2^{\mathrm{a}}$ ed. São Paulo: Aduaneiras, 2001.

VEGA GARCIA, Balmes. Direito e tecnologia: regime jurídico da ciência, tecnologia e inovação. São Paulo: LTr, 2008.

\section{TESES E DISSERTAÇÕES}

AMARAL, Renata Vargas. Retaliação Cruzada na OMC: disciplina e desafios para o sistema multilateral de comércio. Tese de doutorado não publicada, Universidade Federal de Santa Catarina, 2012.

ÁRABE NETO, Abrão M. Cumprimento das decisões do sistema de solução de controvérsias da Organização Mundial do Comércio: análise das medidas de indução e das propostas para seu aprimoramento sob a perspectiva dos países em desenvolvimento. Dissertação de mestrado não publicada, Pontifícia Universidade Católica de São Paulo, 2008.

BASSO, Maristela. Importação paralela: efeitos no comércio internacional e nos direitos de propriedade intelectual. Tese apresentada para o Concurso de Professor Titular da Faculdade de Direito da USP, Departamento de Direito Internacional e Comparado. São Paulo, 2009.

LILLA, Paulo E. de Campos. Direitos de propriedade intelectual e o controle das práticas restritivas da concorrência à luz do acordo TRIPS/OMC. Tese de doutorado não publicada, Faculdade de Direito da Universidade de São Paulo, 2013.

LIMA, Thiago. Desafios internacionais à política agrícola norte-americana: o contencioso do algodão entre Brasil e Estados Unidos e o CAFTA-DR. Dissertação de 
mestrado não publicada, Programa de Pós-Graduação em Relações Internacionais 'San Tiago Dantas’ UNESP-UNICAMP-PUC/SP, 2008.

MEDRADO, Renê G. da Silva. Retaliação coletiva e teoria de formação de alianças no sistema de solução de controvérsias da Organização Mundial do Comércio. Tese de doutorado não publicada, Faculdade de Direito da Universidade de São Paulo, 2011.

OLIVEIRA, Marcelo Fernandes de. Negociações comerciais internacionais e democracia no Brasil: contenciosos das patentes, do algodão e do açúcar na OMC. Tese de doutorado não publicada, Faculdade de Filosofia, Letras e Ciências Humanas da Universidade de São Paulo, 2012.

\section{ARTIGOS CIENTÍFICOS, CAPÍTULOS E ARTIGOS PUBLICADOS EM LIVROS}

ABBOTT, Frederick M. Cross-Retaliation in TRIPS: Options for Developing Countries. In: ICTSID Dispute Settlement and Legal Aspects of International Trade, n. 8, 2009.

. Protecting First World Assets in the Third World: Intellectual Property

Negotiations in the GATT Multilateral Framework. In: Vanderbilt Journal of Transnational Law, v. 22, n. 4, 1989, p. 689-746.

. The TRIPS-Legality of Measures Taken to Address Public Health Crises: Responding to USTR-State-Industry Positions That Undermine the WTO. In: KENNEDY, Daniel L.M.; SOUTHWICK, James D. (ed.). The political economy of international trade law: essays in honor of Robert E. Hudec. Cambridge: Cambridge University Press, 2002, p. 311-342.

ASSAFIM, João Marcelo de Lima. Controles sociais extrínsecos do exercício de direitos de propriedade intelectual: antitruste como tutela de direitos fundamentais. Disponível em:

www.conpedi.org.br/manaus/arquivos/anais/campos/joao_marcelo_de_lima_assafim.pdf>

AZEVÊDO, Roberto. Depoimento. In: COSTA, Sérgio Rodrigues; BUENO, Miguel Garcia. A saga do algodão: das primeiras lavouras à ação na OMC. Rio de Janeiro: Insight Engenharia, 2004, p. 89-97.

BARBOSA, Denis Borges; BARBOSA, Ana Beatriz Nunes. Direitos Autorais e TRIPS, $2005 . \quad$ Disponível em: <http://denisbarbosa.addr.com/arquivos/200/propriedade/direitos_autorais.pdf>.

BAPTISTA, Luiz Olavo. A interpretação e aplicação das regras da OMC nos primeiros anos. In: Revista de Informação Legislativa, n. 162, 2004, p. 265-272.

BARRAL, Welber. De Bretton Woods a Seattle. In: BARRAL, Welber (org.). O Brasil e a OMC: os interesses brasileiros e as futuras negociações multilaterais. Florianópolis: Diploma Legal, 2000.

BARTON, John $\mathrm{H}$. The future of the intellectual property system and consequent negotiation topics. In: Views on the Future of the Intellectual Property System. Geneva: International Centre for Trade and Sustainable Development, 2007. 
BASSO, Maristela. A proteção da propriedade intelectual e o direito internacional atual. In: Revista de informação legislativa, v. 41, n. 162, 2004, p. 287-309.

O Regime Internacional de Proteção da Propriedade Intelectual da OMC/Trips. In: AMARAL JÚNIOR, Alberto do (coord.). A OMC e o comércio internacional. São Paulo: Aduaneiras, 2002, p. 113-160.

; BEAS, Edson. Cross-retaliation through TRIPS in the Cotton Dispute? In: BRIDGES, v. 9, n. 5, 2005, p. 19, disponível em: $<$ www.iprsonline.org/ictsd/docs/Cross_retaliation_cotton_BRIDGES9-5.pdf >.

BOWN, Chad P. Developing Countries as Plaintiffs and Defendants in GATT/WTO Trade Disputes. In: The World Economy, v. 27, n. 1, 2004, p. 59-80.

CORREA, Carlos María. Implementing the TRIPS Agreement in the Patents Field: Options for Developing Countries. In: The Journal of World Intellectual Property, v. 1, n. 1, 2005, p. 75-99.

. Implications of bilateral free trade agreements on access to medicines. In: Bulletin of the World Health Organization, v. 84, n. 5, 2006, p. 399-404.

CORRÊA, Luiz Felipe de Seixas. Os Primeiros Anos do Órgão de Apelação e do Sistema de Solução de Disputa da OMC - uma Perspectiva Histórica. In: BAPTISTA, Luiz Olavo; CELLI JUNIOR, Umberto; YANOVICH, Alan (orgs.). 10 anos de OMC - Uma análise do Sistema de Solução de Controvérsias e Perspectivas. São Paulo: Aduaneiras, 2007, p. 2330 .

DRAHOS, Peter. Four Lessons for developing countries from the trade negotiations over access to medicines. In: Liverpool Law Review, v. 28, n. 1, 2007, p. 11-39.

. Developing Countries and International Intellectual Property Standard-Setting. In: The Journal of World Intellectual Property, v. 5, n. 5, 2002, p. 765-789.

. Negotiating Intellectual Property Rights: Between Coercion and Dialogue. In: International Intellectual Property Law \& Policy, v. 7, 2002, p. 82-1-82-17.

Securing the future of intellectual property: Intellectual property owners and their nodally coordinated enforcement pyramid. In: International Case Western Reserve Journal of International Law, v. 36, n. 1, 2004, p. 53-77.

DEFFAINS, Bruno. Progrès scientifique et analyse économique des droits de propriété intellectuelle. In : Revue d'économie industrielle, v. 79, n. 79, 1997, p. 95-118.

EVANS, Peter B. Building an Integrative Approach to International and Domestic Politics: Reflections and Projections. In: EVANS, Peter B.; JACOBSON, Harold K.; PUTNAM, Robert D. Double-edged diplomacy: international bargaining and domestic politics, $2^{\text {a }}$ ed. Berkeley: University of California Press, 1993, p. 397-430. 
FILHO, Calixto Salomão. Razoabilidade e legalidade do licenciamento compulsório do ponto de vista concorrencial. In: BASSO, Maristela et al. Direitos de propriedade intelectual \& saúde pública : o acesso universal aos medicamentos anti-retrovirais no Brasil. São Paulo: IDCID, 2007, p. 147-166.

FLÔRES JUNIOR, Renato G. O Sistema de Solução de Controvérsias da OMC na Fronteira entre a Economia e o Direito: 10 Anos e 3 Comentários. In: BAPTISTA, Luiz Olavo; CELLI JUNIOR, Umberto; YANOVICH, Alan (orgs.). 10 anos de OMC - Uma análise do Sistema de Solução de Controvérsias e Perspectivas. São Paulo: Aduaneiras, 2007, p. 189-200.

GARBELINI JUNIOR, Antonio. O Sistema de Solução de Controvérsias da OMC nos Próximos Dez Anos: Propostas para Reformas Sistêmicas e Procedimentais. In: BAPTISTA, Luiz Olavo; CELLI JUNIOR, Umberto; YANOVICH, Alan (orgs.). 10 anos de OMC - Uma análise do Sistema de Solução de Controvérsias e Perspectivas. São Paulo: Aduaneiras, 2007, p. 201-222.

HUDEC, Robert E. Broadening the Scope of Remedies in the WTO Dispute Settlement. In: WEISS, Friedl J. (ed.) Improving WTO Dispute Settlement Procedures: Issues and Lessons from the Practice of Other International Courts and Tribunals. London: Cameron, 2000, p. 345-376.

International Economic Law: The Political Theatre Dimension. In: University of Pennsylvania Journal of International Economic Law, v. 17, n. 1, 1996, p. 9-15.

. The New WTO Dispute Settlement Procedure: An Overview of the First Three Years. In: Minnesota Journal of Global Trade, v. 8, n. 1, 1999, p. 1-54.

JACKSON, John H. Dispute Settlement and the WTO: Emerging Problems. In: Journal of International Economic Law, v. 1, n. 3, 1998, p. 329-351.

Perceptions about the WTO trade institutions. In: World Trade Review, v. 1, n. 1, 2002, p. 101-114.

. The case of the World Trade Organization. In: International Affairs, v. 84, n. 3, 2008, p. 437-454.

The Changing Fundamentals of International Law and Ten Years of the WTO. In: Journal of International Economic Law, v. 8, n. 1, 2005, p. 3-15.

KHOURY, Amir. Intellectual property, trade, and development: a view from the United States. In: GERVAIS, Daniel J. (ed.). Intellectual property, trade and development: strategies to optimize economic development in a TRIPS-plus era. Oxford: Oxford University Press, 2007.

LAFER, Celso. Depoimento. In: LIMA, Maria Lúcia L. M. P.; ROSENBERG, Barbara (coord.). Solução de controvérsias: O Brasil e o contencioso na OMC, t. I. São Paulo: Saraiva, 2009, p. 31. 
LIMA, Thiago. As relações entre executivo, legislativo e grupos de interesse norteamericanos no contencioso do algodão. In: Cadernos CEDEC, $\mathrm{n}^{0}$ 73, 2005.

LIMA-CAMPOS, Aluisio G. de. Depoimento. In: COSTA, Sérgio Rodrigues; BUENO, Miguel Garcia. A saga do algodão: das primeiras lavouras à ação na OMC. Rio de Janeiro: Insight Engenharia, 2004, p. 112-116.

LIOTARD, Isabelle. Les droits de propriété intellectuelle, une nouvelle arme stratégique des firmes. In: Revue d'économie industrielle, v. 89, n. 89, 1999, p. 69-84.

LOPES, Jacqueline Spolador; ÁRABE NETO, Abrão M. Atuação dos BICS no Órgão de Solução de Controvérsias da OMC. In: THORSTENSEN, Vera; OLIVEIRA, Ivan T. M. (orgs.). Os BRICS na OMC: Políticas Comerciais Comparadas de Brasil, Rússia, Índia, China e África do Sul. Brasília: Ipea, 2012, p. 331-397.

MILNER, Helen. The Interaction of Domestic and International Politics: The AngloAmerican Oil Negotiations and the International Civil Aviation Negotiations, 1943-1947. In: EVANS, Peter B.; JACOBSON, Harold K.; PUTNAM, Robert D. Double-edged diplomacy: international bargaining and domestic politics, $2^{\mathrm{a}}$ ed. Berkeley: University of California Press, 1993, p. 207-232.

MORAVCSIK, Andrew. Introduction: Integrating International and Domestic Theories of International Bargaining. In: EVANS, Peter B.; JACOBSON, Harold K.; PUTNAM, Robert D. Double-edged diplomacy: international bargaining and domestic politics, $2^{\mathrm{a}}$ ed. Berkeley: University of California Press, 1993, p. 3-42.

MUGNAINI JUNIOR, Mario. OMC aos 10 - O Órgão de Apelação em Perspectiva. In: BAPTISTA, Luiz Olavo; CELLI JUNIOR, Umberto; YANOVICH, Alan (orgs.). 10 anos de OMC - Uma análise do Sistema de Solução de Controvérsias e Perspectivas. São Paulo: Aduaneiras, 2007, p. 157-160.

MURÓ, Julio A. Lacarte. Os Primeiros Anos do Órgão de Apelação e do Sistema de Solução de Disputa da OMC: uma Perspectiva Histórica. In: BAPTISTA, Luiz Olavo; CELLI JUNIOR, Umberto; YANOVICH, Alan (orgs.). 10 anos de OMC - Uma análise do Sistema de Solução de Controvérsias e Perspectivas. São Paulo: Aduaneiras, 2007, p. 3142.

ODELL, John S. International Threats and Internal Politics: Brazil, European Community, and the United States. In: EVANS, Peter B.; JACOBSON, Harold K.; PUTNAM, Robert D. Double-edged diplomacy: international bargaining and domestic politics, $2^{\mathrm{a}}$ ed. Berkeley: University of California Press, 1993, p. 233-264.

O'CONNOR, Bernard. Remedies in the World Trade Organization Dispute Settlement System - The Bananas and Hormones Cases. In: Journal of World Trade, v. 38, n. 2, 2004, p. 245-266.

PAUWELYN, Joost. Enforcement and Countermeasures in the WTO: Rules are Rules Toward a More Collective Approach. In: American Journal of International Law, v. 94, 2000, p. 335-447. 
POLIDO, Fabrício B. P.; CÉSAR, Priscilla M. D. G. Proteção patentária de medicamentos na interface com o direito à saúde: sustentabilidade do programa brasileiro de acesso universal às terapias anti-retrovirais. In: BASSO, Maristela et al. Direitos de propriedade intelectual \& saúde pública : o acesso universal aos medicamentos anti-retrovirais no Brasil. São Paulo: IDCID, 2007, p. 1-114.

PRADO, Victor Luiz do. Mecanismo de Solução de Controvérsias: Fonte de Poder e de Problemas na OMC. In: AMARAL JÚNIOR, Alberto do (coord.). A OMC e o comércio internacional. São Paulo: Aduaneiras, 2002, p. 261-274.

PRAZERES, Tatiana. O Sistema de Solução de Controvérsias. In: BARRAL, Welber (org.). O Brasil e a OMC: os interesses brasileiros e as futuras negociações multilaterais. Florianópolis: Diploma Legal, 2000.

PRIMO BRAGA, Carlos A.; CARSTEN FINK. Reforming Intellectual Property Rights Regime: challenges for developing countries. In: Journal of International Economic Law. 1998, p. 537-554.

PUTNAM, Robert D. Diplomacy and Domestic Politics: The Logic of Two-Level Games. In: International Organization, v. 42, n. 3, 1988, p. 427-460.

REICHMAN, Jerome; LANGE, David. Bargaining around the TRIPS agreement: the case for ongoing public-private initiatives to facilitate worldwide Intellectual Property transactions. In: Duke Journal of Comparative \& International Law, v. 9, n. 1, 1998, p. 11-68.

RORIZ, João H. Ribeiro; TASQUETTO, Lucas da Silva. Propriedade intelectual, serviços e investimentos: panorama de regulação em acordos regionais de comércio celebrados por União Europeia, Estados Unidos, China e Índia. In: Texto para discussão do Instituto de Pesquisa Econômica, n. 1801, 2012, disponível em $<$ www.ipea.gov.br/portal/images/stories/PDFs/TDs/td_1801.pdf >.

RUIZ-FABRI, Hélène. O Papel do Órgão de Apelação: o Show Deve Continuar? In: BAPTISTA, Luiz Olavo; CELLI JUNIOR, Umberto; YANOVICH, Alan (orgs.). 10 anos de OMC - Uma análise do Sistema de Solução de Controvérsias e Perspectivas. São Paulo: Aduaneiras, 2007, p. 59-90.

RUSE-KHAN, HENNING GROSSE. Suspending ip obligations under TRIPS: a viable alternative to enforce prevailing wto rulings? In: Center for International Environmental Law, April 2008, disponível em <www.ciel.org/Publications/TRIPS_IP_7May08.pdf>.

SALAS, Mauricio; JACKSON, John H. Procedural Overview of the WTO EC - Banana Dispute. In: Journal of International Economic Law, 2000, p. 145-166.

SELL, Susan K., Industry Strategies for Intellectual Property and Trade: The Quest for TRIPS, and Post-TRIPS Strategies. In: Cardozo Journal of International and Comparative Law, v. 10, n. 1, 2002, p.79-108.

SHAFFER, Gregory. How to make the WTO Dispute Settlement System Work for Developing Countries: Some Proactive Developing Country Strategies. In: Towards a 
Development-Supportive Dispute Settlement System in the WTO. ICTSD Resource Paper n. 5, 2003, p. 1-65.

. O Sistema de Solução de Disputas na OMC, seus Pontos Fracos e Propostas para Aperfeiçoamento: uma Visão Econômica e de Mercado. In: BAPTISTA, Luiz Olavo; CELLI JUNIOR, Umberto; YANOVICH, Alan (orgs.). 10 anos de OMC - Uma análise do Sistema de Solução de Controvérsias e Perspectivas. São Paulo: Aduaneiras, 2007, p. 161188.

The challenges of WTO law: strategies for developing countries adaptation. In: World Trade Review, v. 5, n. 2, 2006, p. 177-198.

; SANCHEZ, M. R.; ROSENBERG, B. The trials of winning at the WTO: what lies behind Brazil's success. In: Cornell international law journal, v. 41, n. 2, 2008, p. 381-501.

SLATER, Gabriel L. The Suspension of Intellectual Property Obligations Under TRIPS: A Proposal for Retaliating Against Technology-Exporting Countries in the World Trade Organization. In: Georgetown Law Journal, v. 97, 2009, p. 1365-1408.

SPADANO, Lucas Eduardo F. A., Cross-agreement retaliation in the WTO dispute settlement system: an important enforcement mechanism for developing countries? In: World Trade Review, v. 7, 2008, p 511-545.

STRANGE, Susan. Political economy and international relations. In: BOOTH, Ken; SMITH, Steve (eds.). International relations theory today. Cambridge, Polity Press, 1995.

SUBRAMANIAN, Arvind; WATAL, Fayashree. Can TRIPS serve as an enforcement device for developing countries in the WTO? In: Journal of International Economic Law, v. 3, n.3, 2000, p. 403-416.

THORSTENSEN, Vera. O Papel do Órgão de Apelação - Visão das Comunidades Diplomática e Acadêmica. In: BAPTISTA, Luiz Olavo; CELLI JUNIOR, Umberto; YANOVICH, Alan (orgs.). 10 anos de OMC - Uma análise do Sistema de Solução de Controvérsias e Perspectivas. São Paulo: Aduaneiras, 2007, p. 91-112.

. O Programa de Formação da Missão do Brasil em Genebra. In: LIMA, Maria Lúcia L. M. P.; ROSENBERG, Barbara (coord.). Solução de controvérsias: O Brasil e o contencioso na OMC, t. I. São Paulo: Saraiva, 2009.

TOWNSEND, David J. Stretching the dispute settlement understanding: U.S. - Cotton's relaxed interpretation of cross-retaliation in the World Trade Organization. In: Richmond Journal of Global Law \& Business, v. 9, n. 2, 2010, p. 135-165.

VÁZQUEZ, Carlos M.; JACKSON, John H. Some Reflections of Compliance with WTO Dispute Settlement Decisions. In: Law and Policy in International Business, v. 33, n. 4, 2002, p. 555-567.

VENNESSON, Pascal. Idées, institutions et relations internationals. In: Revue française de science politique, n. 5, 1995, p. 857-866. 
WHITEMAN, Allison L., Cross Retaliation Under the TRIPS Agreement: An Analysis of Policy Options for Brazil. In: North Carolina Journal of International Law and Commercial Regulation, v. XXXVI, n. 1, 2010, p. 187-230.

WILLIAMS, Sean. Why Is Brazil an Emerging Market Economy? In: The University of Iowa Center of International Finance and Development. Disponível em: <ebook.law.uiowa.edu/ebook/uicifd-ebook/why-brazil-emerging-market-economy>.

\section{PERIÓDICOS}

BBC News. US warns Antigua and Barbuda over 'piracy site' plan. 9 de janeiro de 2013. Disponível em: <www.bbc.co.uk/news/technology-21247683>.

Inside U.S. Trade. Antiguan Government Announces Formation of WTO Remedies. 17 de julho de 2013. Disponível em: <insidetrade.com/iwpfile.html?file=jul2013\%2Fwto2013_2267a.pdf>.

Inside U.S. Trade. Antigua Mulls Retaliation Options In Gambling Dispute, Including Internet Site. 01 de fevereiro de 2013. Disponível em: <insidetrade.com/Inside-USTrade/Inside-U.S.-Trade-02/01/2013/antigua-mulls-retaliation-options-in-gamblingdispute-including-internet-site/menu-id-710.html>.

Inside U.S. Trade. Minister Says Engagement With U.S. Has Increased Since Antigua Signaled Intent To Retaliate In Gambling Case. 11 de fevereiro de 2013. Disponível em: <insidetrade.com/201302112424298/WTO-Documents/Text-Document/minister-saysengagement-with-us-has-increased-since-antigua-signaled-intent-to-retaliate-in-gamblingcase/menu-id-174.html>.

Inside U.S. Trade. U.S. Expresses Disappointment At Antigua Retaliation, Applauds China's Progress In Raw Materials Case. 21 de julho de 2013. Disponível em: <insidetrade.com/201301292422834/WTO-Documents/Text-Document/us-expressesdisappointment-at-antigua-retaliation-applauds-chinas-progress-in-raw-materialscase/menu-id-174.html>.

Inside U.S. Trade. U.S. IP Holders Cite Legal Objections To Retaliation In Antigua Gambling Case. 15 de fevereiro de 2013. Disponível em: <insidetrade.com/Inside-USTrade/Inside-US-Trade-02/15/2013/us-ip-holders-cite-legal-objections-to-retaliation-inantigua-gambling-case/menu-id-710.html>.

Inside U.S. Trade. U.S. Warns Antigua Not To Impose Retaliation In Years-Old Gambling Case. 21 de dezembro de 2012. Disponível em: <insidetrade.com/Inside-US-Trade/InsideU.S.-Trade-12/21/2012/us-warns-antigua-not-to-impose-retaliation-in-years-old-gamblingcase/menu-id-710.html>.

O Estado de S. Paulo. Acordo Brasil-EUA em algodão pode ter impasse. 18 de abril de 2012. Disponível em: <www.estadao.com.br/noticias/impresso,acordo-brasil-eua-emalgodao-pode-ter-impasse-,862426,0.htm>. 
O Estado de S. Paulo. Brasil pedirá avaliação da OMC sobre subsídios de algodão. 7 de agosto de 2006.2 Disponível em: <www.estadao.com.br/arquivo/economia/2006/not20060807p37450.htm>.

Valor Econômico. EUA suspendem indenização do algodão. 08 de agosto de 2013. Disponível em: <www.valor.com.br/agro/3226034/eua-suspendem-indenizacao-doalgodao>.

Valor Econômico. EUA tentam salvar acordo do algodão. 14 de março de 2013. Disponível em: <www.valor.com.br/empresas/3044676/eua-tentam-salvar-acordo-doalgodao\#ixzz2OAyaCVr5>.

\section{FONTES DE PESQUISA NA INTERNET}

Associação Brasileira da Indústria Produtora E EXPORTAdora dE CARne SuínA (ABIPECS)

$<$ www.abipecs.com.br>

BANCO MUNDIAL

$<$ Www.worldbank.org $>$

BRAZIL TRADE ACTION COALITION (BRAZTAC)

<www.brazilcouncil.org/initiatives/brazil-trade-action-coalition-braztac>

CÂMARA DOS DEPUTADOS

$<$ www.camara.leg.br $>$

COLLECTION OF LAWS FOR ELECTRONIC ACCESS (CLEA)

$<$ www.wipo.int/clea/en/index.jsp>

INSTITUTO BRASILEIRO DO ALGODÃO (IBA)

$<$ iba-br.com $>$

INTERNATIONAL CENTRE FOR TRADE AND SUSTAINABLE DEVELOPMENT (ICTSD)

$<$ http://www.ictsd.org $>$

MINISTÉRIO DAS RELAÇÕES EXTERIORES (MRE)

$<$ www.itamaraty.gov.br>

MinisTÉRIO DO DESENVOLVIMENTO, INDÚSTRIA E COMÉRCIO EXTERIOR (MDIC)

$<$ www.desenvolvimento.gov.br>

NATIONAl CotTON COUNCIL OF AMERICA (NCC)

$<$ www.cotton.org $>$

ORGANIZAÇÃO PARA COOPERAÇÃO E DESENVOLVIMENTO ECONÔMICO (OCDE)

$<$ Www.oecd.org $>$

ORGANIZAÇÃo MUNDIAL DA PROPRIEDADE INTELECTUAL (OMPI)

<http://www.wipo.int> 
ORGANIZAÇÃO MUNDIAL DO COMÉRCIO (OMC)

$<$ WwW.wto.org $>$

SENADO FEDERAL

$<$ www.senado.gov.br>

United States Patent AND TRADEMARK OFFICE (USPTO)

$<$ www.uspto.gov>

UNITED STATES TRADE REPRESENTATIVE (USTR)

$<$ www.ustr.gov>

United STATES DEPARTMENT OF AGRICULTURE (USDA)

$<$ www.usda.gov $>$ 